


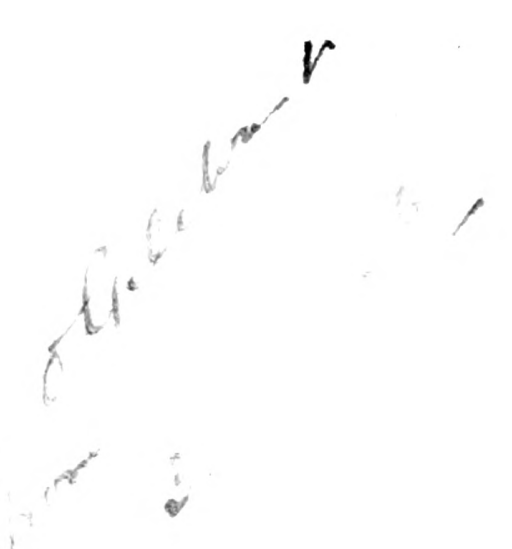


UCSB LIBRARY

$$
X-35683
$$





\section{BRITISH MALAYA}






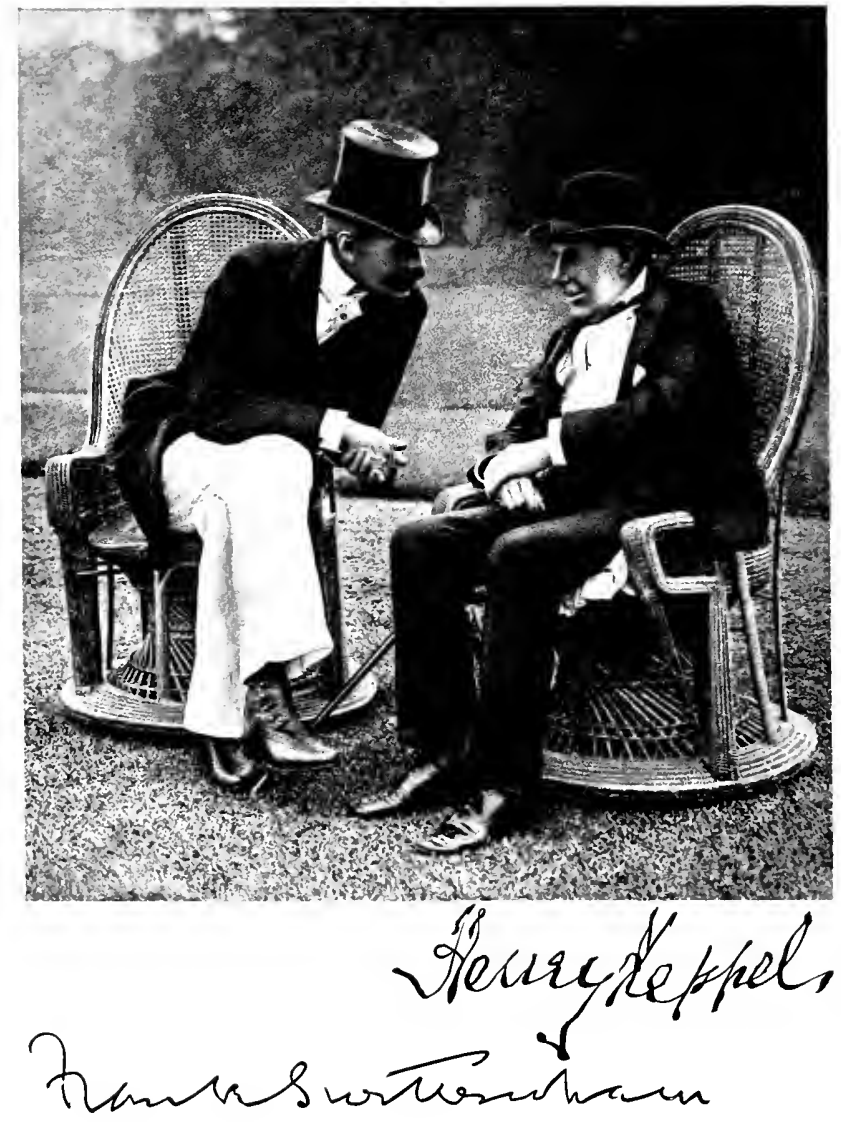


AN ACCOUN'T OF THE ORIGIN AND PROGRESS OF BRITISH INFLUENCE IN MALAYA

LATE GOVERNOR \&c. OF THE STRAITS COLONY \& HIGH COMMISSIONER FOR THE FEDERATED MALAY STATES WITH A SPECIALLY COMPILED MAP NUMEROUS ILLUSTRATIONS REPRODUCED FROM PHOTOGRAPHS \& A FRONTISPIECE IN PHOTOGRAVURE 
PLYMOUTH: WILLIAM BRENDON AND SON, LTD., PRINTERS 


\section{PREFACE}

$\mathbf{I}$

$\mathrm{T}$ is an article of popular belief that Englishmen are born sailors; probably it would be more true to say that they are born administrators. The Englishman makes a good sailor because we happen to have hit upon the right training to secure that end; but, though the Empire is large and the duties of administration important, we have no school where they are taught. Still it would be difficult to devise any responsibility, however onerous and unattractive, which a midshipman would not at once undertake, though it had no concern with sea or ship. Moreover, he would make a very good attempt to solve the problem, because his training fits him to deal intelligently with the unexpected. One may, however, question whether any one but a midshipman would have willingly embarked upon a voyage to discover the means of introducing order into the Malay States, when that task was thrust upon the British Government in 1874 .

The object of this book is to explain the circumstances under which the experiment was made, the conditions which prevailed, the features of the country and the character of the people; then to describe the gradual evolution of a system of administration which has no exact parallel, and to tell what this new departure has done for Malaya, what effect it has had on the neighbouring British possessions. A comparison is also drawn between the progress made in the Malay States under British protection and the other States of the Peninsula, 
whether independent or under Siamese control. In order to give the reader an intelligible account of these matters, it has been necessary to deal briefly with the early history of the Malays and of those Settlements forming the British colony of which the capital is Singapore.

The main idea is to set out accurately the important facts which led to the intervention of Great Britain in the domestic affairs of the countries now known as the Federated Malay States, and to record exactly the steps by which they have been led to their present position as Dependencies of the British Crown. The unique character of the experiment and the success which has attended it are sufficient reasons for describing the efforts which have raised the Malays to a condition of comfort and happiness never before known in their history, and have conferred benefits on Chinese, Indians, and British alike, while opening a new and valuable market to British manufacturers. A further incentive was supplied by the desire of the writer to tell truthfully a story never yet told, though the facts, as far as they concern the Federated States, are no discredit to the British nation, either as the paramount Power in Malaya, or simply as a friend who can sympathize with, and be generous to, a poor neighbour, without considerations of self-interest.

I have felt the disadvantage of writing from intimate knowledge of the events of my time, and, while I could not kill the personal pronoun, for it has a thousand lives and some uses, I have made an effort to scotch it.

My thanks are due to Mr. Basil H. Soulsby, F.S.A., of the Map Department of the British Museum, and to Mr. C. Atchley, I.S.o., Librarian of the Colonial Office, for their kind assistance.

I9 July, 1906.

F. A. S. 


\title{
CONTENTS
}

\author{
CHAPTER I
}

PAGE

The OUtward Appearance of the British Possessions in the Straits of MaLacca . . . . . . I

CHAPTER II

MalacCA-EARLy History

\section{CHAPTER III}

PINANG-EARLY History-LORD Minto's Expedition to

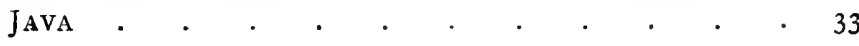

CHAPTER IV

Singapore-EARly History-Sir Stamford RAffles . 62

CHAPTER V

The Straits From 1825-67-The ARRANGement MADE To Settle the Claims of the Sultan and TӗM ĔNggong in REgard to JOHORE • • • . . . . . 78

\section{CHAPTER VI}

THE STRAITS FROM I867-73-SIR HARRY ORD'S ADMINIStration-ANarchy in the Malay States. • • 104

\section{CHAPTER VII}

The Malay : his Customs, Prejudices, Arts, Language, AND Literature . . . . . . . . . 133 
CHAPTER VIII

1874-SIR ANDREW CLARKE-BRITISH INTERVENTION IN

CHAPTER IX

1875-6-Sir WILLIAM JERVOIS-BRITISH RESIDENT OF PÊRAK Assassinated-Punitive Expedition . . . . 194

CHAPTER $\mathrm{X}$

The Evolution of the Residential System-Tin Mining -What the Malay States owe to Chinese Labour AND ENTERPRISE-ROADS-RAILWAYS

CHAPTER XI

The Continued Evolution of the Residential System

-Revenue Farms-Education - Land Settlement

-IRrigation - RUBber CUltivation - CuRRENCY -

PĂHANG

CHAPTER XII

1895-I906-FEDERATION AND ITS RESULTS 272

CHAPTER XIII

Concerning the MALAy States Which ARE NOT INCLUDED IN THE FEDERATION . . . . . . 306

\section{CHAPTER XIV}

How the Development of the Malay States has afFECTED THE NEIGHBOURING BRITISH COLONY, AND THE RELATIONS OF Both WITH THE COLONIAL OFFICEThe Singapore Harbour and Docks-The Civil Service-The Malay Administrator-The Future OF BRITISH MALAYA . . . . . . . . 330 


\section{ILLUSTRATIONS}

Admiral the Hon. Sir Harry Keppel and the Author on a terrace of Government House, Singapore, February, 1903 .

From a photograph by Mr. A. W. Bean, of Singapore.

Group of Tamil Women, Province Wellesley . . $\quad \begin{array}{r}\text { Page } \\ 4\end{array}$

From a photograph by Mr. L. Wray, I.s.o.

MALACCA River

From a photograph by Mr. Alleyne Ireland.

Malay Village in Keppel Harbour, Singapore . . . 8

From a photograph by Lambert and Co.

Government House, Singapore . . . . . . . 10

From a photograph by Lambert and Co.

The Real Malay Lion • . . . . . . . . 14

From a photograph by the late Mr. F. Duberly.

Chinese ACtors

From a photograph by Lambert and Co.

A Chinese Junk and a Malay Schooner . . . . . 56

Photographed by the author.

Collyer Quay and Johnston's Pier, Singapore • . . 66 From a photograph by Lambert and Co.

Entrance of Singapore River . . . . . . . . 82 From a photograph by Lambert and Co.

Cavenagh Bridge and Government Offices, Singapore - 102 From a photograph by Lambert and Co.

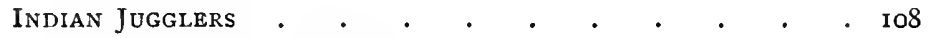

From a photograph by Lambert and Co.

Perak Elephants . . . . . . . . . . . II4

Tin Mines at Lârut . . . . . . . . . . . I16

The Pêrak Valley from the Cottage . . . . . 118

From a photograph by Mr. L. Wray, I.s.o.

The Batu Caves, Š̆langor . . . . . . . . 124

From a photograph by Lambert and Co. 
Group of Malay Sultans

From a photograph by Lambert and Co.

MaLay Shawls

A SÂrong BÂTEK MALAY GOLD WORK

Malay Niello

MALAY GOLD WORK

VESSELS OF SUÂSA

A Niello Basin

Some Specimens of Malayan Ornament

Starting for a Picnic.

KĕDaH PlaIted WORK

A Malay Girl

From a photograph by Lambert and Co.

MALAY FABRICS

A Trengganu Shawl

Malay Silver Ware

THE GăMĂLAN .

From a photograph by Lambert and Co.

A Malay House

From a photograpb by Lambert and Co.

Elephants crossing Perak River

From a photograph by Lambert and $\mathrm{Co}$.

Weapons in Pêrak Regalia.

From a photograph by Mr. L. Wray, I.s.o.

Chinese Children

From a photograph by Lambert and Co.

Railway Construction .

Railway Construction

Railivay Construction .

An old Mosque and a Malay Graveyard From photographs by the author.

Kuala Lumpor in in84. Taken for the author.

Government Offices, Kuala Lumpor

Government Offices, Kuala Lumpor

From photographs by Lambert and Co.

Perak Railways, Gunong Pondok 
From a photograph by Lambert and Co.

On the Residency Terrace, Kuala Kangsar . . . . 288

From a photograph by Lambert and Co.

Conference of Chiefs, 1903

From a photograph by Lambert and Co.

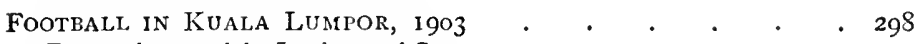

From a photograph by Lambert and Co.

Kuala Lumpor and Back of Government Offices . • . 304

From a photograph by Lambert and Co.

Bull-Fighting, Kelantan . . . . . . . . . 316

From photograph by the author.

TRENGGÂNU

Taken for the author.

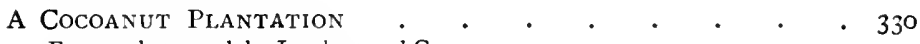

From a photograph by Lambert and Co.

Smelting Works in Keppel Harbour, Singapore . . 332

From a photograph by Lambert and Co.

The Singapore River • $\cdot$. $\cdot$. . . . 334

From a photograph by Lambert and Co.

Mr. G. P. Owen and a Singapore Tiger . . . . .338

From a photograph by Lambert and Co.

The pictures in this book are reproduced, by kind permission, from photographs by Messrs. G. Lambert and Co., of Singapore, by amateurs, who are duly named, and a few are from photographs taken at various times by direction of the Government of the Colony or the Federated Malay States. The pictures of Malay art ware are from vessels and fabrics in the possession of the author. 



\section{BRITISH MALAYA}

\section{CHAPTER I}

\section{THE OUTWARD APPEARANCE \\ OF THE BRITISH POSSESSIONS \\ IN THE STRAITS OF MALACCA}

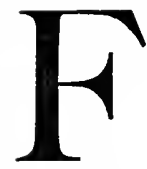

ROM England to Pinang, by way of the Suez Canal, is a voyage of about eight thousand miles, and the last stage of it, from Colombo to Achin Head, the northern point of Sumatra, is practically due east. Turning that corner, the vessel steams down the east coast of Sumatra and then crosses to the Malay Peninsula, Pinang being a very small island at the northern end of the Malacca Strait, just off the coast of what used to be part of the Malay State of Kĕdah. The strip of territory facing Pinang was ceded to the East India Company a century ago; it is now British, and is called Province Wellesley. A reference to the map will show the exact positions of Pinang and the Province, as well as of Malacca, Singapore, and the Federated Malay States, far better than could be done by any written description, but the reader should understand at once that the following pages are concerned with the British Crown Colony known as the Straits Settlements, comprising Pinang, Province Wellesley and the Dindings, Malacca and Singapore; with Pêrak, Selangor, Něgri 
Sambîlan, and Păhang, which constitute the Federated Malay States; with Johore and Trĕnggânu, independent states, the former of which is under British protection; and with a number of other states over which Siam claims suzerainty.

What strikes the traveller, as his ship rounds the northern end of Pinang, is the extraordinary beauty of the scene to which he is introduced with almost startling suddenness. On his right is the island, a vision of green verdure, of steep hills rising from the water's edge till they culminate in a peak $2500 \mathrm{ft}$. high. The sides of these hills are partly forest, partly cultivated, but everywhere green, with the freshness and colour of tropical vegetation washed by frequent rains. About the hills, at varying heights, are picturesque buildings nestling amongst the trees or standing on outcrops of grey rock. Down by the shore-a fascinating in-and-out shore of little sandy bays and little rocky promontories-there is a deep belt of palms, shading but not altogether concealing quantities of brown cottages. Then a broad ribbon of sand, sometimes dazzlingly white, sometimes streaked, or wholly tinted, with burnt sienna; and so the sea, a very wonderful summer sea, blue or grey or pale gold, under different conditions of sunlight, often chequered by great purple and indigo cloud shadows. Along the beach lie boats and nets set out to dry; black nets and brown nets, of immense length, stretched on a framework of poles; quaint objects and infinitely picturesque, but not more so than the fishing stakes, the upper half of which stand above the water, many fathoms from the shore, on the edge of every sand bank. That is what you see as you round the north foreland, by the loftily-placed lighthouse; and then, in a moment, there is the town, and the ship seems to be running into its main street. The white buildings and red roofs, which house a hundred thousand people, crammed closely together on the flat tongue of 
land that stretches, from the foot of Pinang Hill, right out into the Strait which divides it from the mainland, just as though the island were ever trying to get its foot back on to the opposite shore. And when the red roofs cease to catch the eye as a mass, they twinkle at you, here and there, from out the foliage of garden and orchard, till all is merged in green and purple against the background of that great hill.

Close in shore, beside the busy quays, are hundreds and hundreds of strange craft, a very forest of masts and rigging rising from acres of fantastically coloured hulls, of every form and every nationality the Further East produces. There are Chinese junks, small and great, with painted eyes on their low, narrow bows, and quaint erections on their high, wide sterns; there are Malay schooners, and fast boats, and fishing boats, things so small and so crank that only an amphibious creature, like the Malay, would trust himself in them. There are huge, unwieldy cargo boats, manned by natives of Southern India, and propelled by immense heavy sweeps when there is no wind to fill their single square sail. There are wickedlooking Bugis vessels from Celebes, low in the water, with black hulls, fine lines, brown canvas or yellow palm-leaf sails; clumsy old craft from Sumatra and the Malay States; Chinese junks, piled high with firewood or palm thatch; long rakish Chinese fishing boats, loaded with dark brown nets; scores and scores of every eastern boat that swims, navigated by black and brown and yellow men, in every kind of dress and undress known from Japan to Jeddah.

These form the inner line, five or six boats deep, stretching as far south as the eye can reach. Then there are steam launches, of every colour and size, and every degree of cleanliness or dirtiness, rushing or crawling about the harbour, some full of passengers, some empty; while a few ride silently at anchor, here and there, amongst 
the crowd of small coasting steamers, which puff and squeal, arrive or depart, take or discharge cargo, or simply rest between two voyages. And last the outer line, where, in midstream, a few large steamers and sailing vessels strain at cables. But,

There is another shore, upon the other side,

the shore of Province Wellesley, distant from the nearest point of Pinang, about two miles. Far to north and far to south, an endless grove of palm trees fringes the strip of yellow sand, which is sometimes land and sometimes sea. Behind the palms are acres of rice fields, villages, hamlets, and isolated huts; then low hills, forest, and higher hills; range upon range in ever rising steps, till the eye loses count in heat waves, mist, and distance. Nearly due north, a little inland, and distant about thirty-five miles, stands the sharp peak of Gunong Jerai, five thousand feet high. Almost in a line with this mountain, some hazily-blue islands seem to swim on the surface of the sea. Looking south, the coast line of Pinang curves, crescent-wise, to its extreme point, and in the land-locked space of water are islands, large and small, clad like the rest in green. What is called the South Channel is not often used now except by coasting steamers, but the approach to Pinang is even more attractive by this route than by the North Channel. The beauty of the place comes more gradually, sinks deeper into the appreciation, and leaves a picture of form and colour, a sensation of real warmth and real life, which only the East can offer. This feeling will be intensified if the traveller is fortunate enough to see what I have tried to describe under the glamour of a moonlit night.

Yet the pride of Pinang is the Hill, and those who reach the summit will not regret the effort. Looking westward, the eye travels over a wide expanse of jungle-covered slopes, and foot hills, pierced by narrow cultivated valleys, till it rests on the "measureless expanse of ocean." One 


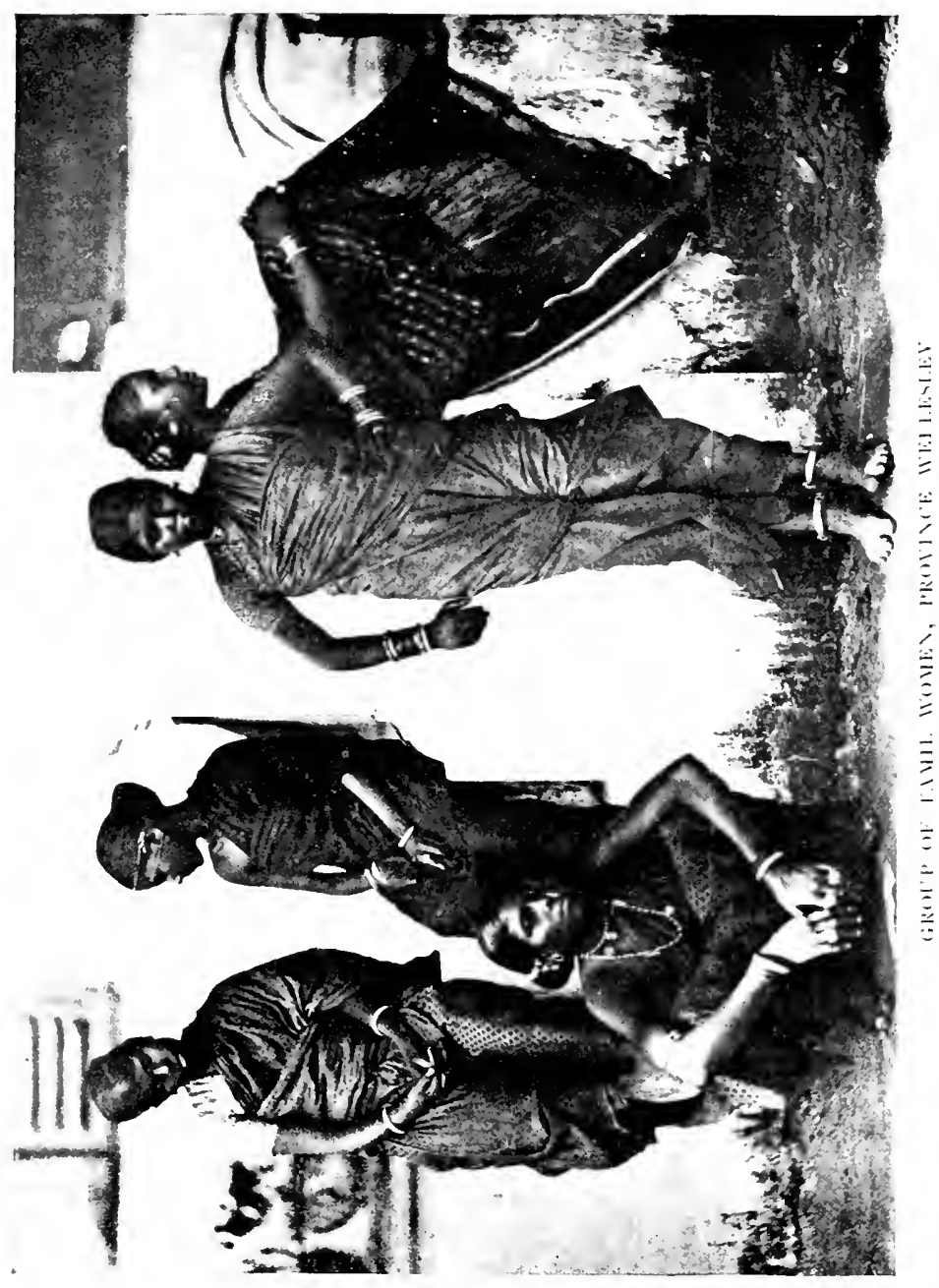



may gaze for hours, fascinated by the ever-changing effects of sunlight and shadow playing on the mirror of the sea. Northward lie the islands, coast, and sharply outlined peak of Kĕdah; while to the south are lower ranges of the main hill, the rice fields and the sinuous coast line of Pinang. Due west is the ship-board view reversed, only softened by height and distance. There are the woods, with their half-hidden dwellings, leading up to a flat but ever-narrowing plain, completely covered by white, redroofed buildings, broken here and there by groups of dark trees. Then the shining stretch of water, carrying its burden of ships and boats, the smaller craft looking like queer black insects; and last, the long coast line of Province Wellesley, with its palms and rice fields and winding rivers, the whole bounded by successive ranges of blue hills, the most distant summits lost in clouds.

Seventy miles south are just visible some islands off the coast of Pêrak, and the traveller who means to see Malacca, and prefers a journey by ship to one by rail, will appreciate their beauty on closer inspection. Mail steamers do not call at Malacca, so the voyage from Pinang, about two hundred and fifty miles, must be made in some humbler vessel. She will probably reach the roadstead before dawn, and the passenger will have the advantage of landing at the ancient port in the early morning. Even small vessels cannot get within less than two or three miles of the shore, and whilst covering that distance in a launch or more probably a Malacca boat, the visitor will first be struck by the curious spectacle of a town with its legs in the sea. The reason is that the houses which face the main street of Malacca have their backs to the shore, and the space between road and sea is so narrow that the Chinese, who love deep, narrow houses, have built out over the water; this end of the building being supported upon high pillars of a peculiar red stone called laterite. The effect is strange but picturesque, and from the 
Malacca River, where Albuquerque and his men performed such deeds of valour, to the northern end of the town, every house on the sea side of the long main street has one foot on land and one in the sea. On the south side of the river, and close to it, is the landing-place; further south still, a long pier with the end still in very shallow water. Beyond the fact that a sea-wall protects a broad strip of close green turf, with great ansenna trees planted at intervals along its edge, while a small hill, crowned by the ruins of an ancient church, shows well above the trees, there is nothing particular to be seen from the boat. Quite near the landing-place, and close to the left bank of the river, is the old Dutch Stadt House, a very solid old-world building, approached by flights of steps. The house is built round a square, stone-paved courtyard, with a double flight of stone steps leading up to the side of the hill, on the summit of which are the walls of the roofless old Portuguese church. There is also on this hill the house of the Resident Councillor of Malacca, with a most attractive garden of very ancient date. The view from the hill is enchanting, whether one looks southward over the orchards and villages to Gunong Lêdang, called Mount Ophir, or westward to the hill which has been appropriated by the Chinese as their fashionable burying-place; or over the dark red roofs of Malacca town, across the rice-fields and cocoanut groves to Cape Rachado in the north. Drive along any road in Malacca and you can feast your eyes on a picture which is typical of cultivated Malaya at its best. On either hand there will be rice fields : emeraldgreen when newly planted, golden with ripe grain, or brown when fallow. These are studded by topes of lofty palms shading a few brown huts. The distance is always shut in by hills of a marvellous blue. But of all roads the most lovely is that which runs along the very edge of the coast, passing through palm groves and villages, with vistas of rice fields and blue hills on one side, and 


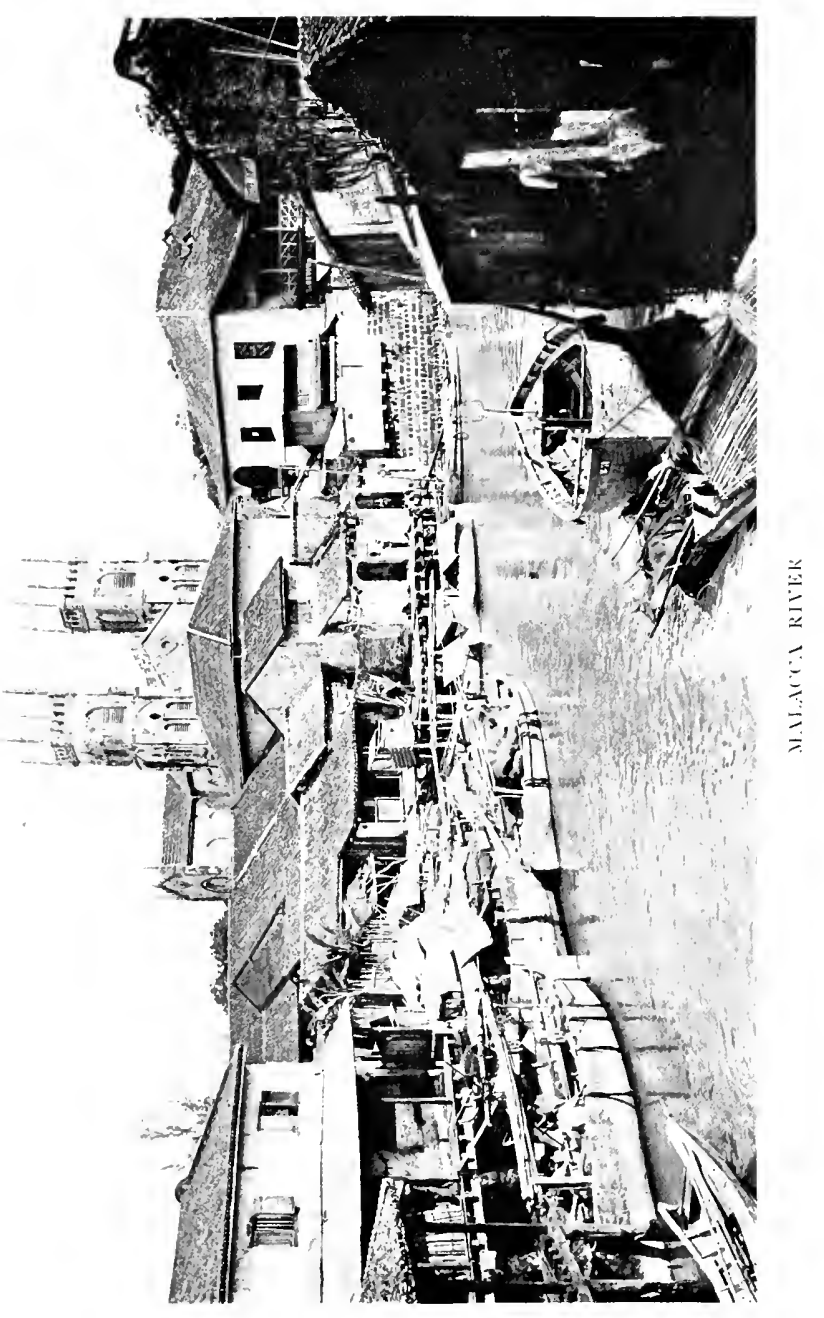



on the other spaces of water, green or blue, grey or bloodred, molten silver or black, under the varying conditions of sunlight and shadow, of eastern day or eastern night. There are no Malay villages, no country scenes, more picturesque than those of Malacca; and if the visitor chances to meet a wedding party in bullock carts, or a Malay funeral procession; if he witnesses a fleet of fishing boats putting out at sunset, or homing at dawn; and has eyes to see and to appreciate the colours, the movement, the strange people with their strangely beautiful surroundings, the scene will live in his memory for all time.

Singapore is 120 miles south-east of Malacca, a few miles north of the southernmost point in Asia; the island stands sentinel at the narrow gate which divides the Straits of Malacca from the China Sea. A dozen ocean-going steamers pass into or out of its harbours every day, and most of these vessels call at no other port in the Straits. By good fortune, it commonly happens that, owing to the dangers of navigation in such narrow seas, one arrives at dawn and leaves at sunset. In either case, the most unobservant must be struck by a scene as beautiful as it is unusual. Long before making the Karîmun Islands (which are thirty-five miles from Singapore, on the right as you come from the west), the coast of the Malay Peninsula has been visible; a low coast covered by mangroves growing out into the water. Ten miles from the narrow entrance to the harbour the vessel passes between the mainland (and later the shores of Singapore) and a succession of small islands, which gradually converge till they seem to bar further progress. Just when the space of water has so narrowed that the forts and guns, on either side of the channel, become visible to the practised eye, the bow of the vessel swings to the left, through jade-green eddying waters, and she slowly forces her way along a channel so narrow that it will only just admit the safe meeting of two 
large steamers. Still there are islands, quantities of islands, large and small, but only large by comparison. They are covered with foliage, with gardens, with cool pleasant-looking bungalows, with barracks and other military buildings. Near the water the soil, where you can see it, is more red than brown, and the rocks, where they come through the soil, are much more red than grey. But the water is always green, and clear, and swirling; it looks and is very deep, and the foliage of the islands is repeated on its surface, in dark green reflections. Then the passage widens somewhat, the shore of Singapore becomes one interminable line of wharves, against which lie an almost unbroken chain of ships, flying every known flag, but mostly the red ensign of Britain. The wharves, the warehouses, the docks, the coal-sheds, seem parts of some gigantic manhive, where men of every colour, in every conceivable garb, load and unload, gather and stack and store, every imaginable human production, from locomotives and lanterns, to mail bags and matches, pianos and pickaxes. Behind the ships, and wharves, and docks, and warehouses are roads, with a ceaseless traffic of people, carts, and carriages; then villages and green hills, chequered by houses and gardens. Across the waterway there are still islands, far as the eye can reach; but they are curving seawards, and whilst those nearest are covered, or partly covered, by buildings and chimneys, or groups of Malay huts straggling off the land right out into the water, as though they had walked there on stilts, there are others green with pineapples or jungle, and others still, away in the distance, like opals on the shining surface of the water. It is a thousand to one that the vessel, which brings the stranger from a distance, will tie up alongside the wharves, and he will then enter the town by a drive along a dusty, crowded road. The more excellent way is that of the small steamer which, skirting the long line of wharves, makes for the roads and gives the traveller the best and most compre- 


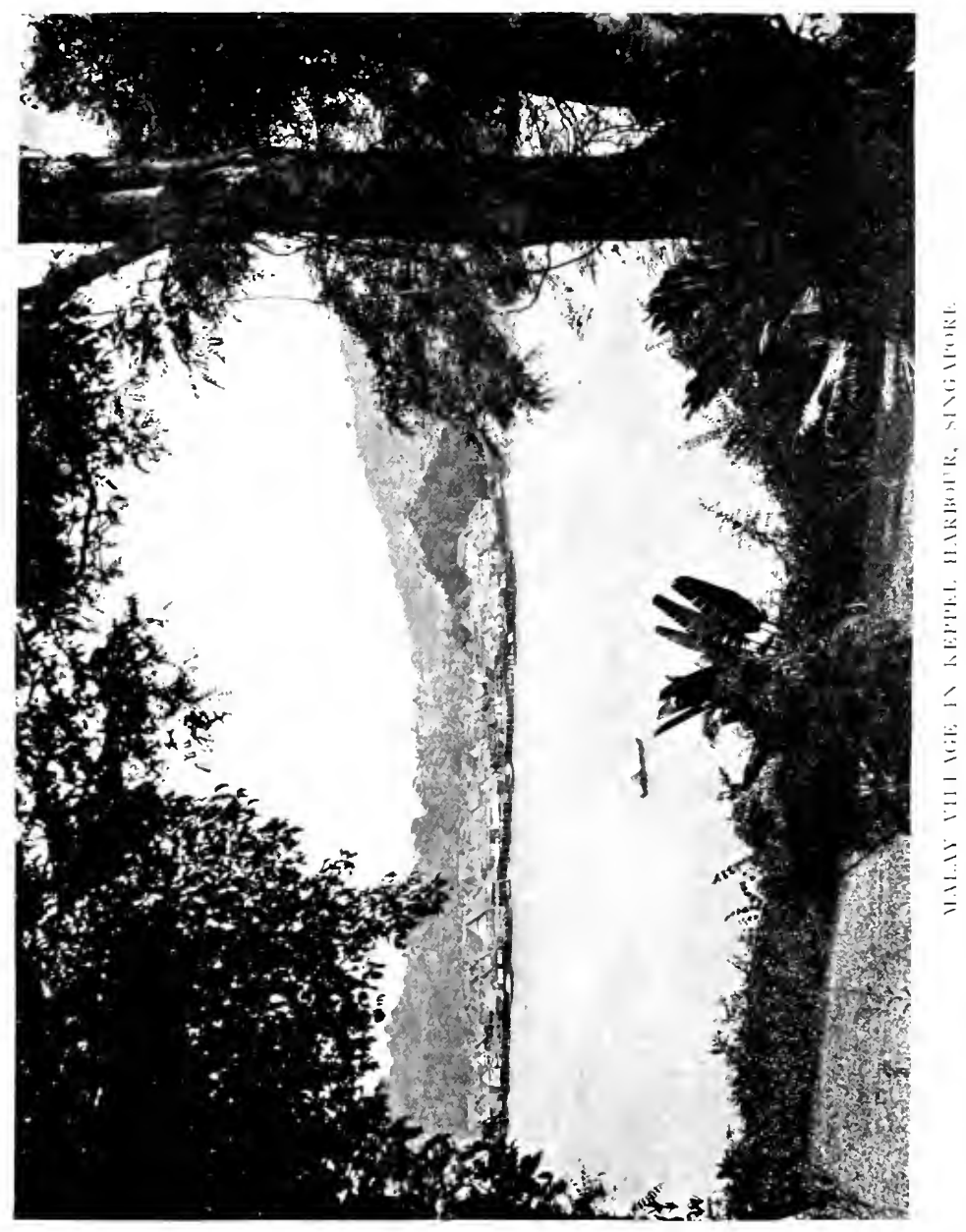



hensive view of the Lion City, Queen of Far Eastern Seas.

Between the docks and the town, a bold headland, crowned by a battery, juts out into the water, and forms the southern horn of a crescent which embraces the whole city; till the land curves round to a far distant point, where a thick grove of palms faintly indicates the northern horn. Singapore from the Roads is very fair to see. From Mount Palmer (the fortified headland), to the Singapore River-that is, about one-third of the crescent-there is an unbroken mass of buildings, shining and white, facing the sea. The next third is green with grass and trees, through which are caught glimpses of public buildings and the spires of churches, backed by low hills, on one of which, in the distance, stands white and stately the Governor's residence. The remaining third is again covered by closely packed houses, seen indistinctly through a forest of masts. The space enclosed by the beach and a line drawn from horn to horn of the crescent, would contain about I 500 acres of water, and that is the real harbour of Singapore. Native craft, mainly Chinese junks, great and small, with hundreds of other vessels of every form, and size, and rig, lie crowded together in the northern half, while the southern half is occupied by numbers of small coasting steamers. Outside, in the deeper water, four or five miles from shore, is the man-of-war anchorage. As for launches and cargo boats, fishing boats, passenger boats, and pleasure yachts, their name is legion, and their goings to and fro, day and night, are ceaseless. The Singapore river is so tightly packed with hundreds of small craft that it is difficult enough to preserve a fairway to admit of passage. On shore it is the same; the place is seething with life, and, to the unaccustomed eye, the vehicles to be met with in the streets are almost as strange as the boats in the harbour; while such a medley of nationalities, such a babel of languages, surely finds no parallel in all the 
world. Of colour and life there is enough to satisfy the greediest; of heat and dust and strange smells there are usually too much for the western visitor. Only the extraordinary novelty of the scene, the wonderful colouring, the unusual interest, will banish every other feelingfor a time.

Each of the three Settlements, which together form the Straits Colony, has attractions of its own, peculiar to itself, though all have much in common. Pinang has its hill, with that glorious view, and it also has Province Wellesley, where one can see the Malay and his rice fields, but not quite as they are to be found in Malacca. There is a romance of age, of experience, of a full life lived, which remains with Malacca to-day as the heritage of her history. Malacca has drifted out of the stream of endeavour, away from the struggle for riches and greatness. She has drifted into the back waters of Time, and her attractions, for the dreamer, the lover of beauty and the student, may be greater than those of her sisters. Singapore has a history too, far more significant than and as full of thrilling incident as that of Malacca; but of her former glory not a trace is left, not a stone remains to recall her ancient greatness, and little more than tradition to establish the fact that it ever existed. Yet it did exist, seven or eight hundred years ago, and perhaps not then for the first time; and to-day it has come again, with new life, to flourish as never before. No stranger will approach this far eastern fortress, these wharves, and docks, and coalsheds, weaving stories of its long-forgotten past; his eyes will glean unmeasured delight from the rich colours of ever-changing landscape and seascape, the countless islands and the wonderful harbour, half circled by a sunlit shore. But his mind will carry away an impression foreign to the east, a sense of hurry, of movement, of boats driven fast through the water, by steam or sail, of straining oars propelling deep-laden barges, of bustling 


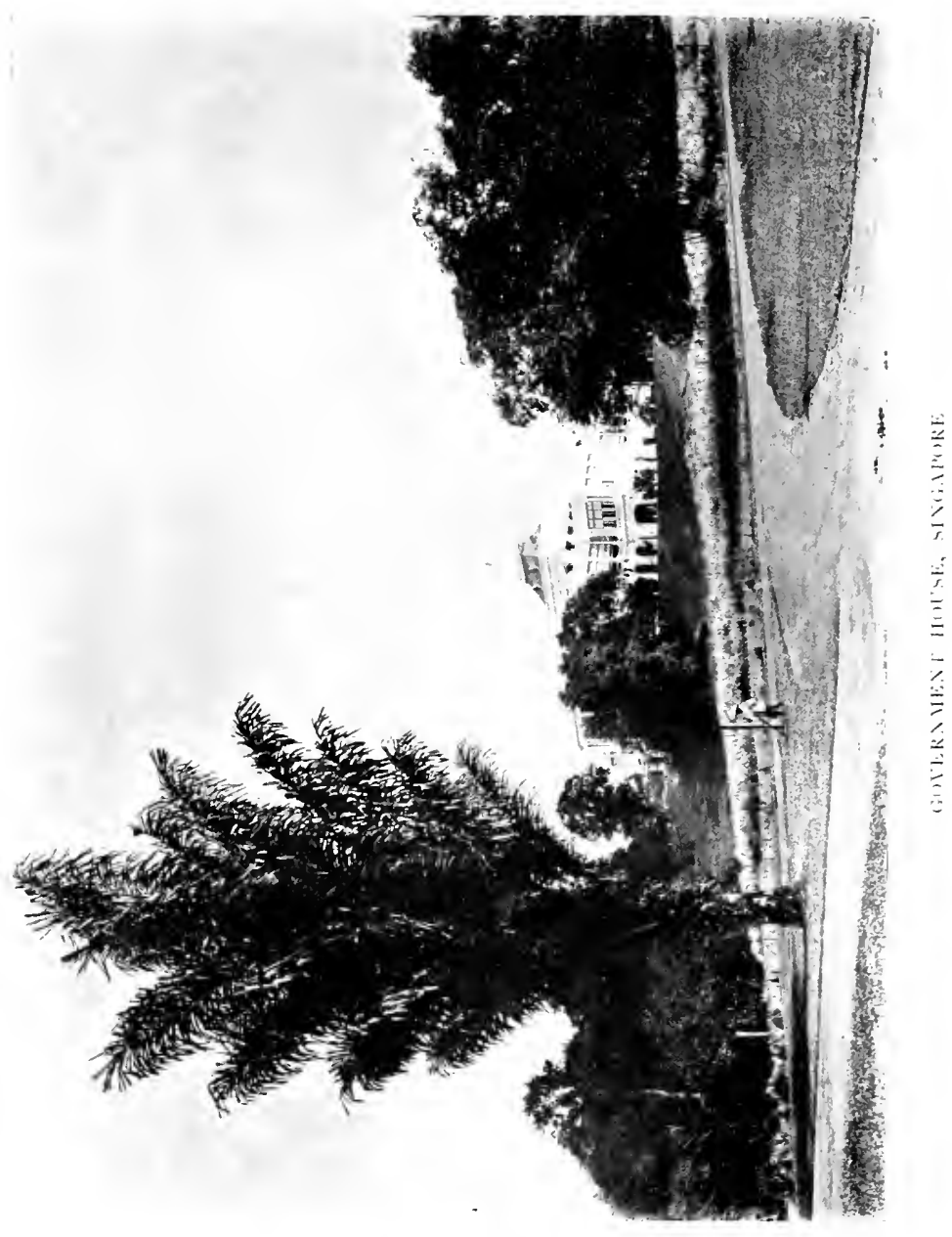



crowds jostling each other in the streets, of white and yellow, brown and black men, intent on something that matters, that makes for money. That is the new Singapore, where the traveller and his kind are the only idlers. 


\section{CHAPTER II}

\section{MALACCA-EARLY HISTORY}

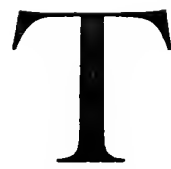

$\mathrm{HE}$ best recognized authority on the early history of the Malays is a book styled Sejâra Malâyu, the Malay annals. The foundation for this work was a manuscript of Malay history, which somehow seems to have found its way to Goa, and about the year 1612 it was entrusted to an unknown scribe, who "edited" the book, and, in the process, no doubt did what he thought was necessary to invest it with importance and bring it up to date. The book, as it now appears, is so manifestly untrustworthy in details that it is difficult to place much reliance upon the general statements contained in it. Like the ramblings of the insane, who jumble up fact with fiction, there is truth in this record; but as there is very little supporting testimony, and small means of winnowing the wheat from the chaff, it is impossible to do more than quote from the annalist those statements to which early European writers seem to have given a somewhat large credence. According to the Malay story, a certain Raja Bachitram Shah (afterwards known as Sang Sĕperba), with two followers, suddenly appeared at a place called Bukit Siguntang Maha Meru, in Palembang, Sumatra, and the Raja described himself as a direct descendant of Alexander the Great. The story was accepted, and Sang Sěperba became the son-in-law of the local chief; but, not content with ruling over Palembang, he sailed to Java, to Bentan (where he left a son, 
Sang Nila Utâma), and finally back to another state in Sumatra, named Měnangkâbau.

Sang Nila Utâma, having married the daughter of the Queen of Bentan, left that island and settled on the neighbouring island of Singapurra, where he founded the Lion City in or about the year I 160.1 Singa is Sanskrit for a lion, and pura for a city, and the fact that there are no lions in that neighbourhood nowadays cannot disprove the statement that Sang Nila Utâma saw, in II60 or thereabouts, an animal which he called by that name-an animal more particularly described by the annalist as "very swift and beautiful, its body bright red, its head jet black, its breast white, in size rather larger than a hegoat." That was the Lion of Singapura, and whatever else is doubtful the name is a fact; it remains to this day, and there is no reason why the descendant of Alexander should not have seen something which suggested a creature unknown either to the Malay forest or the Malay language. It is even stated, on the same authority, that Singapûra had an earlier name, Tămâsak, which is explained by some to mean a place of festivals. But that word, so interpreted, is not Malay, though it has been adopted, and applied to other places which suggest festivals far less than this small tropical island may have done, even so early as the year I I6O. It is obvious that the name Singa-pûra was not given to the island by Malays, but by colonists from India, and if there were an earlier name, Tămâsak or Tamasha, that also would be of Indian origin. The fact proves that the name Singapûra dates from a very early period, and strongly supports the theory that the Malays of our time are connected with a people who emigrated from Southern India to Sumatra and

$1 \mathrm{Mr}$. J. R. Logan, a recognized authority, writing in 1848 , thinks it probable that Singapura was originally peopled from the island of Bentan, and that Sang Nila Utâma, arriving from the coast of Sumatra, married the daughter of the then Raja of Singapura and settled in the island, becoming its ruler. 
Java, and thence found their way to the Malay Peninsula. It seems to be accepted that Sang Nila Utâma founded or developed a famous city by the river and on the hill of Singapûra, where he lived for many years, and died in I208. He was succeeded by his lineal descendants, and the city grew and prospered, and attracted trade from West and East, till a jealous neighbour, the Raja of Majapâhit, in Java, sent a great expedition to attack Singapûra. The attack failed miserably, and the Javanese were beaten off; but in. 1252-still according to the annalist-the then Raja of Singapura, one Iskandar, or Alexander, by name, publicly impaled one of his wives for a supposed offence, and the lady's father, a high official named the Bĕndahâra, was so enraged, that he invited the people of Majapâhit to come over, and promised to open the gates of the citadel for them. The Raja of Majapâhit eagerly accepted this offer, sent over an immense fleet and army, and, the gates being duly opened in the dead of night, the Javanese entered and put most of the inhabitants to the sword. A few escaped from the city and the island, and after wandering through the Peninsula, settled at Malacca, where they founded a new city, from which their descendants were driven by Albuquerque and the Portuguese in I 5 I I.

In leaving for the present the Malay annals, it is interesting to record, in the words of the writer, the dire fate of the Bêndâhara who betrayed his master, even though the provocation was considerable. "By the Power of God Almighty," says the annalist, "the house of Sang Ranjûna Tapa (the Bĕndahâra) became a ruin, its pillars fell, and rice was no longer planted in the land. And Sang Ranjûna Tapa, together with his wife, were changed into stones; and these are the stones which may be seen lying by the river of Singapurra."

In comparatively modern times, early in the last century, there was still lying by the river of Singapore 


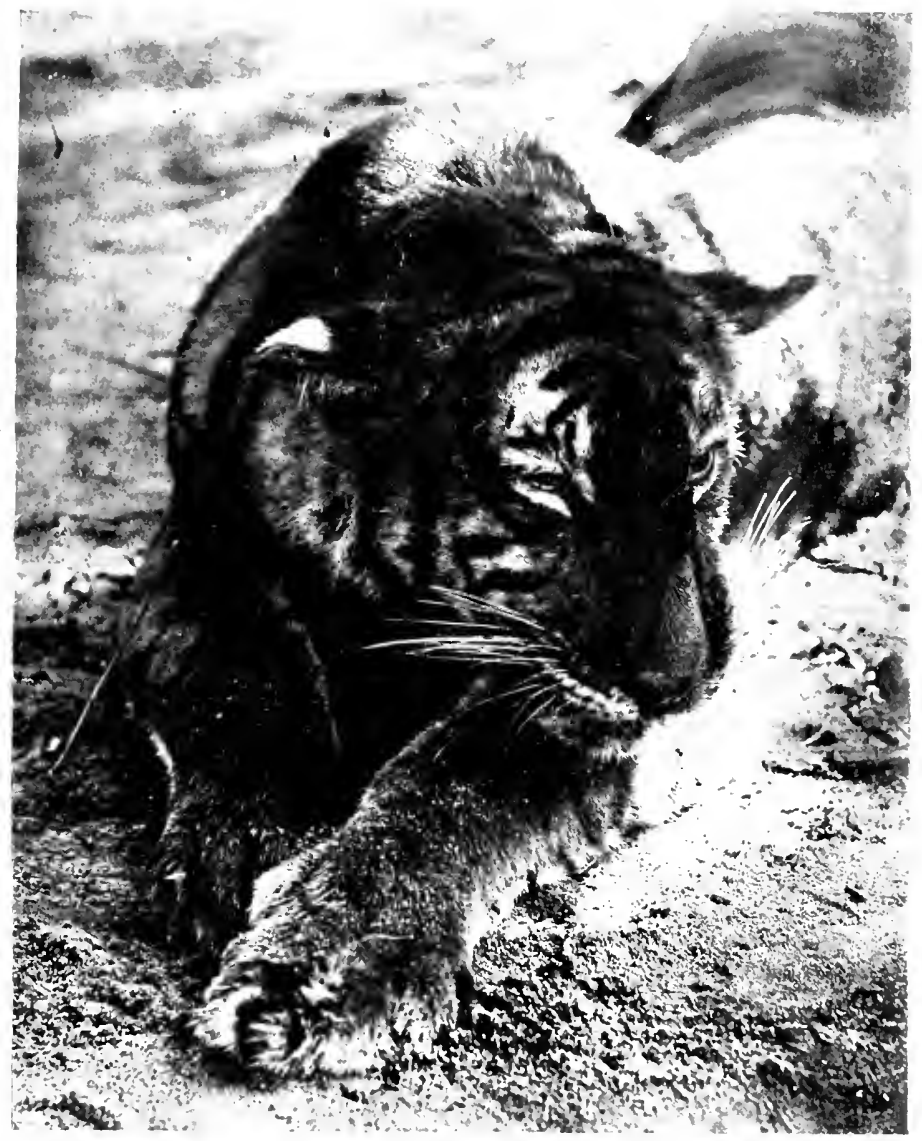

IHE REAL M.JW I.ION 

a strange stone with an inscription that was never deciphered. The stone has disappeared; by an act of vandalism it was blown to pieces, and though some fragments were rescued and sent to the Calcutta Museum, the rest of it helped to fill the swamp on which the present town is built.

With the doings of Albuquerque and his expedition we are on somewhat safer ground, though the opinions of the Portuguese historians in regard to the Malay are open to serious question in the light of modern knowledge. An enthusiastic Englishman, Mr. John Crawfurd, a member of the East India Company's service, and one of the first Residents of Singapore, visited Malacca in I82I and wrote: "We cannot, as Europeans, but survey with pride the spot on which stood the bridge by which Albuquerque, at the head of seven hundred Europeans, stormed walls and intrenchments that were guarded by thirty thousand barbarians." Unfortunately, it is more than probable that the seven hundred Europeans, the thirty thousand barbarians, and the walls and entrenchments were all equally imaginary. That Albuquerque, so soon after the discovery of the route round the Cape, and so immediately after his own arrival in India, should have undertaken two hazardous expeditions against such a distant and little known place as Malacca, clearly proves the courage and the foresight of this great adventurer; but as to the amount of resistance he met with, in the absence of any record from Albuquerque himself, we may form a judgment from the fact that Malays do not build walls, and that Lewis Wertemanns, of Rome, writing of a voyage made by him in 1503 , says :

"Sailing westward towards the city of Malacka, we arrived in eight days' sailing. Not far from this city is a famous river named Gaza, the largest I ever saw, containing twenty-five miles in breadth. On the other side is seen a very great island called Sumatra and is 
of old writers named Taprobina. When we came to the city of Malacka (which some call Meleka) we were incontinent commanded to come to the Sultan, being a Mahomedan and subject to the great Sultan of China and payeth him tribute, of which tribute the cause is, that more than eighty years ago that city was builded by the Sultan of China for none other cause than only for the commodity of the haven, being doubtless one of the fairest in that ocean. The region is not everywhere fruitful, yet hath it sufficient of wheat and flesh and but little wood. They have plenty of fowls as in Calicut, but the Popinjays are much finer. There is also found Sandilium and Tin, likewise elephants, horses, sheep, kyne, pardiles, bufflos, peacocks, and many other beasts and fowls. They have but few fruits. The people are of blackish ashe color. They have very large foreheads, round eyes, and flat noses. It is dangerous there to go abroad in the night, the inhabitants are so given to rob and murder. The people are fierce, of evil condition and unruly, for they will obey to no Governor, being altogether given to rob and murder, and therefore say to their Governors that they will forsake country if they strive to bind them to order, which they say the more boldly because they are near unto the sea and may easily depart to other places. For these causes we spent no long time here, but hiring a brigantine, we sailed to the Island of Sumatra where in few days sailing we arrived at a city named Pidir, distant about eighty miles from the continent or firm land."

That was in I503, and though the writer is far from accurate in his statements, and appears to have mistaken the Strait of Malacca for the River of Gaza (by which name the River Muar, in Johore, appears to have once been known), he would surely have mentioned the fortifications if there had been any worth the name.

1 Other writers give Taprobane as the ancient name of Ceylon. 
The following passage is from the Hon. E. J. Stanley's translation of the MS. attributed to Duarte Barbosa, but said by Mr. Stanley to be really the work of Magellan. It is specially interesting for the description of the Malays, so often regarded by ignorant people as savages. The MS. dates from the beginning of the sixteenth century:-

"This city of Malaca is the richest trading port and possesses the most valuable merchandise, and most numerous shipping and extensive traffic that is known in all the world. And it has got such a quantity of gold that the great merchants do not estimate their property nor reckon otherwise than by bahars ${ }^{1}$ of gold, which are four quintals each bahar. There are merchants among them who will take up singly three or four ships laden with very valuable goods and will supply them with cargo from their own property. They are very well made men and likewise the women. They are of a brown colour and go bare from the waist upwards, and from that downwards cover themselves with silk and cotton cloths, and they wear short jackets half way down the thigh of scarlet cloth, and silk, cotton, or brocade stuffs, and they are girt with belts, and carry daggers in their waists wrought with rich inlaid work; these they call querix. ${ }^{2}$ And the women dress in wraps of silk stuffs, and short skirts much adorned with gold and jewellery, and have long beautiful hair. These people have many mosques, and when they die they bury their bodies. Their children inherit from them. They live in large houses and have gardens and orchards and pools of water outside the city for their recreation. They have got many slaves who are married with wives and children. These slaves live separately and serve them when they have need of them. These Moors who are named Malays are very polished people, and gentlemen, musical, gallant, and well proportioned."

Whether Malacca, as Albuquerque found it in $15 \mathrm{II}$,

${ }^{1}$ One bahar or bhara is equal to 400 lbs. av. $\quad 2$ Kris. 
was a fortress or only a nest of pirates, it is certain that it was a place of great repute as a harbour and mart, and its fame, not only as an emporium for the immediate neighbourhood, but also as a convenient place of call and shelter, on the route to the furthest East, attracted Albuquerque to its conquest and occupation. There the Portuguese remained for I 30 years; there they built the Church of Our Lady of the Annunciation, and there was the scene of the labours and supposed miracles of St. Francis Xavier. Let the travelled stranger stand, to-day on the summit of that hill, by the walls of that ancient church, and as he looks across the close turf-

Where Sun and Shadow chequer-chase the green,-

through the branches of the poinsiana-a flat, brown network, covered and high-piled with glorious crimson blossom, just edged with foliage-down to the shore close beneath him, out to the roadstead with its picturesque boats, an island here and there; and then across the blue water, away out to the horizon, where sea and sky meet in another blaze of brilliant colour; he will admit that the East has few fairer prospects, and that Albuquerque, and those with him, did well when they chose this spot as the site of the Church of Our Lady del Monte. But the authority of the Portuguese never reached beyond the confines of the town, and it is very doubtful whether Malacca in its palmiest days ever equalled the prosperity and importance of Singapore under the Malay rulers in the twelfth and thirteenth centuries.

In $16_{4}$ I the Dutch drove the Portuguese out of Malacca, and at once proceeded to firmly establish themselves behind the strong fortifications. For all that, the fortunes of the place steadily declined, and early in the eighteenth century the population had dwindled to five thousand people all told. The Dutch made Malacca the headquarters of their enterprise in the Malay Peninsula, and 
opened trading stations-factories, as they were calledin Perak, Selangor, and other Malay States, where tin was bought and commodities bartered with the Malays. From about I779 till I795 (when Malacca was taken by the British) the trade of the place revived; but the occupation of Pinang by the East India Company and later, the establishment of an English station at Singapore, deprived Malacca of all importance as a great eastern market and port of call. Under the Treaty of Vienna, Malacca was handed back to the Dutch in I8I8; but the place came finally into our possession under the treaty with Holland of 1824 .

Curiously enough, it was only so lately as I86I, long after the days when the earliest English settlers in Singapore had done their best to collect all available information concerning the past history of the Malay Peninsula, that a manuscript, by Manuel Godinho de Eredia, written at Goa, in I6I3, and addressed to Philippe III, King of Spain, was discovered in the Royal Library at Brussels. This MS., while describing Malacca and many other parts of the Malay Peninsula, gives the writer some claim to be considered as one of the discoverers of Australia, not in his own person, but through a small expedition dispatched by him in I6Io. The paper was only published in I882, with all its maps and illustrations, together with a translation in French by M. Léon Janssen, member of the Geographical Society of Brussels. The work is full of interest as regards Malacca and its neighbourhood, and claims respect from the fact that Godinho de Eredia was himself born at Malacca, on I6 July, I563, being the son of de Juan de Heredia Aquaviva and a Malay lady, the daughter of the Raja of Supa, in Macassar. At thirteen years of age Godinho was sent to the Jesuit College at Goa, to be educated for the priesthood, but his passion for geography and exploration led him to abandon the religious life and devote himself to difficult and dangerous journeys 
of discovery in the Malay Peninsula and Archipelago. Godinho states that the name "Malacca" was only given in I4II, and that it was derived from a tree; a likely enough supposition and one generally accepted. Twentyfive miles to the north-west of the town of Malacca is a rocky promontory, called, in Godinho's time and to this day, Tanjong Tuan by Malays, Cape Rachado by Europeans. The Malay name was given because Tanjong Tuan 1 is the burial place of the founder and first ruler of Malacca, and Godinho says that in 1600 the remains of his marble tomb were still to be seen on the promontory. Godinho is responsible for the statement that from this point there was, in the time of Claudius Ptolemy, A.D. I63, a very narrow isthmus to a place called Tanjong Balvala, in the island of Sumatra. He adds that the people of the Peninsula used to walk across this isthmus to Sumatra, or Samâta, as it was first known, and he says the word Samâta means Peninsula, and that Ptolemy called it the Golden Chersonese.

There have been great differences of opinion amongst old writers as to the derivation of the word "Sumatra." None of the suggested derivations are very convincing, but if Sumatra is, as Godinho states, a corruption of Samâtathe name given in some of the old maps of the island-the explanation is not far to seek ; for the Peninsula Malay might say, Tânah Sa-mâta, which means the land opposite, the land facing us. On a clear day the hills of Sumatra are visible from the lighthouse on Cape Rachado, and, if ever there was a narrow isthmus between the Peninsula and the island, it would be natural for the Malays of Malacca to call the land at the other end of that isthmus Tânah Sa-mâta-mâta. That suggestion rests on very slender grounds, and Sir Henry Yule says that Samudra(the spelling adopted by certain earlygeographers) is Sanskrit for the sea. In Godinho's time the Malay

1 Tanjong Tuan means "the Headland of the Master." 
Peninsula was called Ujong Tânah-Land's End-whereas now it is called Negri Malâyu, i.e. the Malay Country, while Sumatra is called Pulau Përcha, the torn island, as though it had been torn off the mainland, or Tânah Săbrang, the country across the water. There is a very similar instance in the case of Pinang. That island, now separated from the mainland by a wide and deep stretch of sea, is still called "Tanjong" by all Malays; tanjong. being the Malay for a promontory.

Again, it has been suggested that Sumatra is a corruption of Samudra, the name of a small place on the east coast, which was probably frequented by early navigators, and so gave its name to the whole island. That seems probable, for it is very doubtful whether the natives of the place have ever called the island "Sumatra," though they would understand that this was the name by which it was known to white men.

A careful examination of ancient charts, so far as they are to be found in the British Museum, shows that the first mention of Sumatra is to be found in Martin Waldseemüller's Carta Marina, dated 1516, where the island is called Samotra. It appears under the same name in the Harleian Mappemonde of 1536 (British Museum Add. MS. 5413), and in this map a very distinct shoal or bank is marked exactly at the spot where Eredia places the narrow isthmus of sand between Cape Rachado and Sumatra. Pierre Descelier's Mappemonde of I 546 and 1550 give Sumatra, and also indicate the shoal. It is also interesting to note that the first mention of Singapore on any ancient map is found in the Theatrum Orbis Terrarum of Abraham Ortelius, dated Antwerp, I570, where the island appears as Cincapura. All these authorities give Taprobane as the ancient name of Sumatra, and by none of them is this island called the Golden Chersonese.

M. Henri Cordier, commenting on a passage in Odoric 
de Pordenone's Voyages en Asie (temp. I350), which alludes to the custom of branding with hot irons employed by certain tribes in Sinohara (Sumatra), says that this refers undoubtedly to one of the kingdoms of Sumatra, which has given its name to the whole island. $\mathrm{He}$ adds that the name Sumatra has been known from the earliest times, and was called by Chinese voyagers Sou-men-ta-la. M. Verbeck, in his Annals of the Extreme Orient (I, page I86), says that the real native name of the island is Poulo Pertjah-or Pulau Percha as we should now write itand that is correct. M. Devic (Merveilles de l'Inde, page 235) quotes a curious legend from the Malay chronicles of Pasi-probably he means the Sijara Malayu already mentioned-to account for the origin of the name Sumatra. It is to this effect : that one Marah Silou, while hunting with dogs in the north of the island, came upon a huge ant as large as a cat, which he caught and ate, and that he made his dwelling in that place and called it Samoudra, which means a great ant. As a matter of fact Sĕmut is the Malay for ant; but the story is far-fetched, and appears to have been invented by the annalist to give colour to the apparent resemblance between Sermut and Sumatra. Pauthier, in a note on page 565 of his Marco Polo, says: "Sumatra, a name of Indian origin (Soumatra -excellent matter or substance), was given (to this island) without doubt at the time when the Buddhist religion was introduced there."

Godinho gives careful plans of the original Malacca fort, built by Albuquerque in $15 \mathrm{II}$, and of the much more elaborate works existing in 1605 . The latter, which are minutely described, were in the shape of a pentagon, the base inland, the apex on the seashore with a strong tower on the water's edge. The circumference of the walls (partly stone and partly timber) was 655 brasses (one "brasse" being equal to ten hands, say five feet), and they contained the castle and palace of the 
governor, the palace of the bishop, the hall of the Council of State, and that of the Brothers of Mercy. There were five churches within the walls, that of Our Lady of the Annunciation being inside the Jesuit College on the hill, while another was in the Convent of the Dominicans, and a third in that of the Augustins. The cathedral church was called Nôtre Dame de l'Assomption.

There were four gates in the walls of the fortress leading to three "faubourgs," or suburbs, the principal being styled Tranqueira, which is explained to mean palissade, on account of the proximity of a long rampart of stone. Godinho concludes his notice of the town with the statement that there lived in the fortress, besides the garrison, three hundred married Portuguese with their families. Within and beyond the walls there were 7400 Christians, with four religious houses, fourteen churches, two hospitals with chapels, and several hermitages and oratories.

The Portuguese writer, whilst furnishing information on many other subjects, describes the flora and fauna of the Peninsula with minuteness and considerable accuracy, but he says there is a tree called the "snake tree" (canafistola), which is so powerful a protection against poison that when a venomous snake sees even the root of it he has to bow his head. Then, amongst the beasts of the land, he describes the armadillo, his scales, and his habit of tying himself up in a ball; but what is most surprising is that the elephant has a deadly fear of this creature, because if attacked the armadillo fights, seizes the elephant by the trunk, and, "according to the wild tribes," remains fixed there for several days, until the elephant dies of hunger, thirst, and exhaustion. There are snakes, too, which carry shining stones in their heads-bezoar stones, no doubt. Again, according to certain Malays, Godinho affirms that a stone was taken from the head of a snake 
and sold to some merchants from Mecca. "The stone was white, crystalline, with changing lights of red and blue, and sometimes it shed a light in the darkness of night, but not a strong light, because the stone was only the size of a partridge's egg." Godinho says the wild tribes of the Peninsula are convinced that these stones are found in the heads of some snakes and some beasts. He adds that in Corea there are centipedes of an amazing length, which carry a light strong enough to light a room; and, warming to his subject, tells how, in I594, the King of Bali, near Java, had in his palace a hare with four eyes, two for ordinary use, and two on the top of his head, which were so luminous that they sufficed to light the King's palace at night. It is only fair to state that though Godinho was aware that the Malay forests contained tailless apes, he does not pretend that they were in any way related to the wild tribes who, he says, went about naked and resembled satyrs. Godinho states, with perfect truth, that Malay fortifications were always of wood, with a deep and wide outside ditch, in the bottom of which were placed sharpened sticks, termed caltrops. Godino quotes classic authorities to prove that there was, in A.D. 163, an established trade between Egypt and the Coromandel coast, and from the latter to the Malay Peninsula and Sumatra. The small isthmus already mentioned was, he says, destroyed by violent tempests and the Malacca Strait formed. He traces the course of this trade as, by land, from Alexandria to Cairo (the ancient Bubalis), and thence to Suez, where ship was taken, and the merchants sailed down the Red Sea to Aden; then coasting along the shores of Arabia, Persia, and Hindustan they made for the Coromandel coast and Taprobane, the ancient name of Ceylon. From there they sailed past the mouths of the Ganges to Ujong Tânah (the Malay Peninsula), and reached a port called Sabbâra, in the Sabbâra Sea, to the north of Tanjong Tuan and the 
isthmus. Godinho suggests that Sabbâra ${ }^{1}$ (so called by Ptolemy) was the port of Calan (the present Klang, on the coast of Selangor), and he adds that from this place the merchants made their way to Tanjong Tuan, and thence by the isthmus to Sumatra-the Golden Chersonese. Or they might have sailed across the Sabbâra Sea to Auro, or Aru, in Sumatra, and thence made their way by river to Tacola, or Tico, in the centre of the island. The return voyage was the same journey reversed. Pliny says that in the time of Caius Cæsar, the son of Augustus, the navigation of the Red Sea to Arabia was well known, and after his time the extension of that voyage to Persia and Ceylon was recognized; but, as Godinho points out, it is strange that before Ptolemy no writer mentions the journey to Ujong Tânah and Sumatra, while Marco Polo, who made his return journey from China by Sumatra and Ceylon in 1292, knew nothing of the Malay Peninsula. All this is very interesting, and seems to support Godinho's contention that Malacca grew to importance subsequent to I 292. This view also accords with the statement of the Malay annalist that Singapore was destroyed in 1252, and Malacca was peopled by refugees from that city. Godinho fixes the date of Malacca's foundation as I4II; but it was probably much earlier, though it may not have attained to any great importance till the time named.

Speaking of the Malâka of his day, Godinho says :-

"This land is the freshest and most agreeable in the world. Its air is healthy and vivifying, good for human life and health, at once warm and moist. But neither the heat nor the moisture is excessive, for the heat is tempered by the moist vapours arising from the waters, at the same time that it counteracts the dampness of the excessive rains of all seasons, especially during the changes of the moon."

1 There is an island, off the east coast of Sumatra, almost exactly opposite to Tanjong Tuan, called Segaro. If this be merely a coincidence it is certainly a curious one. 
It is worthy of note that Godinho states that there were springs of mineral oil-minhat tanat he calls it, meaning no doubt minyak tânah, the Malay for "earth oil." Such springs probably exist, and it would be a good thing for Malacca if they could now be located.

There is a chapter on "Gunoledam," which is the writer's method of spelling Gunong Lêdang, the Malay name for a mountain near Malacca, known to Europeans as Mount Ophir. On this hill there were, and still are, a few aborigines called Orang Bĕnua, and this is what Godinho says of them :-

"These Bĕnua of the woods, in the same way and by the same methods and the use of the same words, transform themselves into tigers, lizards, crocodiles, and other animals; they are thus enabled to communicate with the absent, like the Sorcerers of Tuscany who had power to show distant objects. In this regard I must again mention dom Georges de Santa Lucia, first Bishop of Malacca, who tried to put a stop to the evil done by these Forest Bĕnua when, in the guise of tigers, they came by night to Malaca to kill unresisting women and children. The Bishop wished to excommunicate them and made public prayer in the Cathedral. Then, after High Mass and the procession of the fête of the Assumption of Our Lady of the Fortress, he solemnly excommunicated these tigers. Since that time they have never entered the villages, nor killed men, women, or children, and the Christians thank God for it. Many natives, struck by this miracle, were converted in the year 1560 , as well as a number of idolatrous Chelis."

If any excuse is needed for these references to and quotations from the work of Manuel Godinho de Eredia, it must be found in the great interest which attaches to a record, written so long ago, by one who was born and bred in Malacca. Moreover, the manuscript has not, so far as 
I am aware, received any attention from English writers on Malâya, though Godinho possessed and utilized opportunities of research and observation which were not shared by better known authorities. François Valentyn, for instance, whose great work on the East Indies was published at Dordrecht and Amsterdam in 1726, devotes a considerable space to the Malay Peninsula, and especially to Malacca, which was then under the dominion of Holland. Speaking of Malacca, Valentyn says :-

"The country in which it is situated was called by Ptolemy and the Ancients, Terra or Regio Aurifera, or the gold-bearing country, and Aurea Chersonesus or the Golden Peninsula, the latter name being conferred on account of its being joined to the countries of Tana-Sery ${ }^{1}$ (Tenasserim) and Siam by a narrow neck of land. It is the southernmost country of the continent of India, and is separated from the island of Sumatra by a fine strait which is known by the name of the Strait of Malakka, and sometimes by that of the Strait of Singapoera (commonly called Sincapoera) after a very ancient town on its shores. The strait has to be penetrated many miles before the important city of Malakka is reached."

This statement in reference to Ptolemy and the Golden Chersonese is at variance with that made by Eredia, whose contention, founded on Ptolemy's Map XI of Asia and other ancient charts, is that Sumatra was the Golden Chersonese of Ptolemy. The arguments of geographers of the sixteenth, seventeenth, and eighteenth centuries must be weighed by the knowledge of those times; but if Eredia was mistaken on this point, the error probably disposes of the story of the narrow isthmus between Cape Rachado and Sumatra; for if the Malay Peninsula was Ptolemy's Golden Chersonese, then the isthmus was the

1 Malay, Tânah Sri, the fortunate land ; or perhaps Tânah Sireh, i.e. the country of the sireh vine. 
Isthmus of Kra, in the north of the Peninsula, between Southern Siam and Northern Malaya. The Sinus Sabaricus would then have been the Gulf of Martaban or the Mergui Archipelago, and the Sinus Perimulicus the Gulf of Siam.

To return to Valentyn.

Continuing his account of Malacca, the historian says :-

"On the north-west side of the town there is a wall, a gate, and a small fortress; a river also enters the sea here, the water of which is fresh at low water and salt at high water. It is full forty paces wide, and the stream is usually very strong. It is called the Crysorant. There is another river on the east side of the town. The land on the opposite side of the river is of average height with that of the town, to which it is joined by a wooden bridge; but that on the south-east side is very marshy, and is generally flooded after rain,except a narrow strip along the beach, which is somewhat higher. There are several handsome and spacious streets in the town, but unpaved; and many fine stone houses, the greater part of which are built after the Portuguese fashion, very high. They are arranged in the form of a crescent. There is a respectable fortress, of great strength, with good walls and bulwarks, and well provided with cannon, which, with a good garrison, would stand a hard push. Within the fort there are many strong stone houses and regular streets, all bearing tokens of the old Portuguese times; and the tower which stands on the hill has still a respectable appearance, although it is in a state of great dilapidation.

"This fortress, which occupies the hill in the centre of the town, is about the size of Delfshaven, and has also two gates, with part of the town on a hill, and the outer side washed by the sea. It is at present the residence of the Governor, the public establishment, and of the garrison, which is tolerably strong. Two hundred years ago it was a mere fishing village, and now it is a handsome city. 
"In former times the fort contained eleven or twelve thousand inhabitants, but now there are not more than two or three hundred, partly Dutch and partly Portuguese and Malays, but the latter reside in mere attap huts in the remote corners of the fort. Beyond it there are also many handsome houses and tidy plantations of cocoanut and other trees, which are occupied chiefly by Malays.

"This is a city remarkably well situated for trade, the Straits having been long frequented by shipping, especially from Bengal, Coromandel, Surat, Persia, Ceylon, Java, Sumatra, Siam, Tonkin, Tsjina (China), and many other parts, so that the gross revenue in the year 1669 , consisting of import duty at Io per cent, export duty at 3 per cent, with certain local taxes, amounted to 74,950.19.0 florins."

So Valentyn draws the picture of the Malacca of two hundred years ago, then the only European possession in Malaya ; but why the historian, whose work was published in 1726 , should have gone to the year 1669 for his statistics is somewhat strange, especially as he gives a list of the Dutch governors of Malacca from I64I to I7I7. In leaving this famous authority, we must acknowledge our indebtedness for what is probably the first edition of a now well-known story. It is too good to be lost, or put in any words but his own :-

"People are not safe here (i.e. Malacca) from wild beasts when out in the forest. The Heer van Naarsen (a friend who himself related to me the occurrence) was once accidentally ran against by a tiger, and on several other occasions he encountered this animal, when his horse always became unmanageable. There are also many elephants and other beasts. This gentleman also related to me that he once saw a tiger spring upon a deer that had taken to the water to escape, but the deer got away, and the tiger was in the meantime pulled down by an alligator." 
This proneness to accept the marvellous tales of strange countries was not peculiar to Valentyn and Eredia. The latter seems to have gone to the Orang Benua when he wanted a new sensation, and they gratified him with stories of the Witch of Ginong Lêdang-stories which they probably more than half believed themselves. But it seems rather unkind of the Heer van Naarsen, the man who "was accidentally ran against by a tiger," to have taken advantage of his personal friend, a minister of the gospel, to tell him that story about the tiger and the crocodile (it must have been a crocodile, for there are no alligators in Malaya), just because the good man had accepted the "accident" without question. Still, all things are possible, and if it was the same tiger which rubbed himself against van Naarsen's leg, and afterwards, by another accident, jumped into the crocodile's mouth, it was as good a way as any other for the author to get rid of the hero of his romance. The Portuguese explorer told us that the Malacca tigers of the middle of the sixteenth century were dealt with by excommunication; a hundred, or a hundred and fifty years later, the Dutch historian leads them, by a chapter of accidents, to a sudden and painful end. There are some survivors still, and from time to time their adventures give colour to stories almost, if not quite, as strange as these. After all, it is these simple touches which make the dry bones of the dead live again for us; and with the writings of these worthies before us, with some knowledge of the place and the people they describe, we can see first Eredia, then Valentyn, strolling round the walls of Malacca, passing through her gates, lingering in her streets, gossiping with her people, listening to the last thrilling tale, the latest marvel of the land or sea.

And in the evening, when the sun was setting and each, in his day had climbed to the top of that hill in the centre of the fortress, as the bells of the churches rang out the angelus, or called the Hollander to his simpler worship, 
they would gaze out through the green leafage, over the red roofs and level rice fields; now to blue hills inland, and now to the summer sea, with its burden of strange craft, loaded with all the riches of the fragrant and mysterious East. And each in turn-the son of Portugal and Malâya, not less than the reverend and learned Hollander -would dwell with pride on his country's coveted possession of Malacca, famous city of romantic story, the goal of the earliest and most venturesome spirits of western adventure. As the Portuguese explorer did not dream that the Dutch would drive his countrymen from Malacca, so the historian was spared the mortification of knowing that Holland, in her turn, would have to yield her position in Malâya to England. Neither foresaw that the days of Malacca were already numbered; and that, whatever flag waved over Portuguese Cathedral and Dutch Stadt House, the glory of Malacca was on the wane, and her place in the far eastern seas was to be taken, her commerce and importance increased a thousandfold, by the English occupation of the once famous, but then uninhabited, island of Singapore. So the ancient Singapura disappeared, struck down violently, betrayed and sacked in a night, and the survivors journeyed north-west and founded Malacca, drawing thither much of the trade and prosperity of their earlier home. Now again, after six hundred years, Singapore rises from its ashes and draws to itself the trade of all rivals within a thousand miles. Having regard to the position and circumstances of Singapore, the fact need cause no surprise. What is strange is that, in those six hundred years, there should have been no Portuguese, no Hollander, no Englishman, with curiosity and application enough to make himself acquainted with the ancient history of Singapore, and prescience enough to realize that the existence, which had been suddenly and violently stifled, would revive in to a new and far more vigorous life the moment it was carefully and intelligently 
treated. The opportunity was there always, but the hand to seize it, to make the most of it, was wanting. The fire of the ancient city was not dead, it smouldered. Sir Stamford Raffles came, nursed the ashes, fanned them with foresight, with infinite knowledge, with tact, and, above all, with firm determination. Almost at once the place blazed into life and fame; and to-day Singapore, counted by the tonnage of her shipping, is the eighth largest port in the world, with a population of 250,000 people of forty different nationalities. 


\section{CHAPTER III}

\section{PINANG-EARLY HISTORY- \\ LORD MINTO'S EXPEDITION TO JAVA}

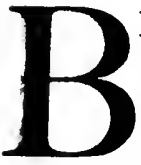

ETWEEN the disappearance of Malacca, as a serious commercial rival, and the rise of Singapore to the position of first importance in Malaya, a good many things happened to which reference must be made for a proper comprehension of succeeding events. Of these happenings the chiefest was the occupation of Pinang in 1786 . Let it be remembered that, at that date, the Dutch were still in possession of Malacca, and we had no foothold in the Straits. Our nearest station was Bencoolen, on the east coast of Sumatra. Now Bencoolen, where the East India Company founded a trading station in 1684 , is only notable for two incidents in a long but inglorious existence. Its chief value to the Company was that it became a centre for the collection of pepper, and the directors in London wrote to their agent at Bencoolen desiring that the cultivation of white pepper should be encouraged to the exclusion of the black variety. The Board was blissfully ignorant of the fact that the vine produces pepper, and whether it goes to the market black or white depends on whether it is gathered before or after the fruit has ripened. This was pointed out to the authorities in Leadenhall Street, and for a time they were very considerate to their representative in Bencoolen. But they had their revenge. A serious shortage was discovered in the stock of silver dollars stored in the Bencoolen Trea- 
sury, and the agent reported that, after full inquiry, the loss could only be ascribed to the ravages of white ants. When next the Company had occasion to send stores to Bencoolen they included a parcel of steel files, and, being asked what they were for, the Board replied that they should be used to file the teeth of the white ants!

The Honourable East India Company, doing then a large business with China, had become alive to the value and importance of the trade of the Malay Peninsula and Archipelago, from which the Company was shut out by Dutch exclusiveness. The Company had, therefore, given instructions to several likely men to look out for a suitable spot on which to found a station, the first object aimed at being a good anchorage and place of victualling, watering, and refitting for their vessels engaged in the China trade. One of the persons so commissioned was Mr. Francis Light, a shipmaster, who had considerable dealings with the Malay State of Kĕdah, on the west coast of the Peninsula, about three hundred miles north of Malacca. It appears that in I77I Mr. Light had suggested to Warren Hastings the desirability of occupying the island of Pinang and the island of Sallang (otherwise called Ujong Sâlang or Ujong Kâlang, now corrupted into Junk Ceylon), two islands belonging to Kĕdah, lying, at some distance apart, off the coast of that State. Although Mr. Hastings favoured the plan, and steps were actually taken, in 1780 , to raise a private subscription in order to secure Sâlang, war with France put a stop to the project. In 1786, however, Mr. Light opened negotiations at Kĕdah (where he was on excellent terms with the Sultan), for the cession of Pinang to the East India Company, and, meeting with a favourable reception to his proposal, he obtained a letter from the Sultan to the GovernorGeneral, with which he proceeded to Calcutta. In a subsequent letter from Pinang, dated i 8 June, I787, addressed to Lord Cornwallis, Mr. Light says :- 
"On my arrival at Calcutta (in I786), I found Mr. Macpherson in the chair, who readily accepted the King of Queda's (i.e. Kĕdah) offer, but declined taking Sâlang, as it would have required a greater force than could with any degree of convenience have been sent. . . Not only the commanders of the British vessels, but foreigners, continually complained of there being no place of safety east of the Bay of Bengal for ships to take shelter in and to refit at. Every one seemed to think it a duty incumbent on the English East India Company, they enjoying the greatest possessions and the readiest means for effecting it."

This time Mr. Light's suggestion was accepted, and he returned to Kĕdah the bearer of a favourable reply from the Company's chief representative. At Kĕdah he made his preparations, and on I4 July, I786, in the afternoon, he sailed from that place and anchored at Pinang the next morning. The following days were spent in landing troops, stores, and guns, in clearing ground, pitching tents, building huts, lining out a fort, and setting up a flagstaff. On I I August, I786, Mr. Light hoisted the British flag in the presence of all his people and the captains of two of the Company's ships-the Vansittart and the Valentine-which had arrived the previous day, and he took formal possession of the island by the issue of the following proclamation:-

"These are to certify that agreeable to my orders and instructions from the Honourable GovernorGeneral and Council of Bengal, I have this day taken possession of this Island called Pooloo Pinang now named the Prince of Wales Island, and hoisted the British Colours in the name of His Majesty George the Third and for the use of the Honourable East India Company, this eleventh Day of August, One Thousand Seven Hundred and Eighty Six, being the Eve of the Prince of Wales' Birthday.

"In the presence of the underwritten"(Signed) FRANCIS Light." 
There was once a tradition, cherished by lovers of romance, that Light fell in love with and married a daughter of the Sultan of Kĕdah, and that that potentate gave the island of Pinang to the lady as a marriage portion. There is no foundation for this story. Francis Light was a Suffolk man, and was adopted and educated by a relative named William Negus, of Melton, who died in 1773. Light first joined the Navy; he was a midshipman on board H.M.S. Arrogant in 1761 , but he soon abandoned that service, sailed to the east, obtained the mastership of a trading vessel, and made his headquarters at the island of Sâlang, where, or in Siam, he probably met the lady who became the mother of his children. This lady is described, in Francis Light's will, as Martina Rozells, and it may be inferred that she was of Portuguese extraction. It is clear from what follows that she had not the remotest connexion with the cession of Pinang to the East India Company, though she no doubt went with Light to Pinang at the time of its occupation, or very shortly afterwards, and died there, but of the date there is no record. When Mr. Light made his first proposal, in $177 \mathrm{I}$, the idea of occupying Pinang and Sâlang was probably his own; but between 1780 and 1785 the Government of Bengal turned its attention to the acquisition of a station in the Far East, and from one of Mr. Light's letters it appears that they had already, by some other hand, unsuccessfully sought the island of Pinang from the Sultan of Kĕdah. Mr. Light, in reporting the result of his negotiations, says :-

"As I understand this Government had made application to the King of Kĕdah for the island of Pinang without success, with the consent of the Governor-General I made use of the influence and interest I had with the King and Ministry to procure a grant of the island of Pinang to the Honourable Company. The King of Kĕdah, who now solicits your friendship and alliance, has 
sent by me a grant of the island of Pinang, and has annexed to the grant some requests."

Now that was the beginning of a great deal of trouble, of much heart-burning, much shedding of blood, and infinite misery to thousands of entirely innocent people. It was to result in an unprovoked attack on Kĕdah, when the country was wasted by fire and sword ; the people subjected to barbarous tortures, nameless horrors; their Sultan, our ally, and many of his subjects driven into perpetual exile, and the country placed under a foreign yoke. The cause of these untoward events was the cowardice of the East India Company, ending in a breach of faith which sullied the British name and weakened its influence with Malays for very many years.

To relate the whole of the circumstances, and quote all the documents necessary for an exact appreciation of the case, would be of interest to very few readers to-day; but enough of the story must be told to prevent, if that be possible, the repetition of proceedings so damaging to native belief in British honour and good faith. There is another, some think a better, reason for recalling these events, and that is expediency. An opportunity is offered to one generation, and it is declined, or lost, or muddled. But history repeats itself, and not infrequently the opportunity comes again to another generation, and is sometimes again neglected. Our position in the Malay States to-day is such that further mistakes would be inexcusable, though that fact alone is not sufficient to save us from them.

This is the letter from the Sultan of Kĕdah, containing the conditions on which he was prepared to cede the island of Pinang to the East India Company, and it is well to remember, in reading this and subsequent quotations from documents written at the time or when the events were fresh in men's minds, that apologists for the East India Company contend that the Sultan of Kĕdah was, and 
always had been, a vassal of Siam, and that as such he had no power to cede territory, no right to make treaties, no reason to expect that the Company would either promise or give him protection against the power and probable wrath of his master.

The letter. Written on Tuesday, 24th Shawal A.H. I I 99 :-

"Whereas Captain Light, Dêwa Râja, came here and informed me that the Râja of Bengal ordered him to request Pulau Pinang from me to make an English Settlement, where the Agents of the Company might reside, for the purpose of trading and building ships of war to protect the island and to cruise at sea, so that if any enemies of ours from the East or the West should come to attack us, the Company would regard them as enemies also and fight them, and all the expenses of such wars shall be borne by the Company. All ships, junks, or prows, large and small, which come from the East or the West and wish to enter the Kĕdah river to trade, shall not be molested or obstructed, in any way, by the Company, but all persons desirous of coming to trade with us shall be allowed to do as they please; and at Pulau Pinang the same.

"The articles of opium, tin, and rattans are monopolies of our own, and the rivers Muda, Prai, and Krian are the places from whence tin, rattans, canes, besides other articles, are obtained. When the Company's people, therefore, shall reside at Pulau Pinang, I shall lose the benefit of this monopoly, and I request the Captain will explain this to the Governor-General, and beg, as a compensation for my losses, 30,000 dollars a year, to be paid annually to me as long as the Company reside at Pulau Pinang. I shall permit the free export of all sorts of provisions, and timber for shipbuilding.

"Moreover, if any of the Agents of the Company make loans or advances to any of the Nobles, Chiefs, or Rajas of the Kedah country, the Company shall not hold me 


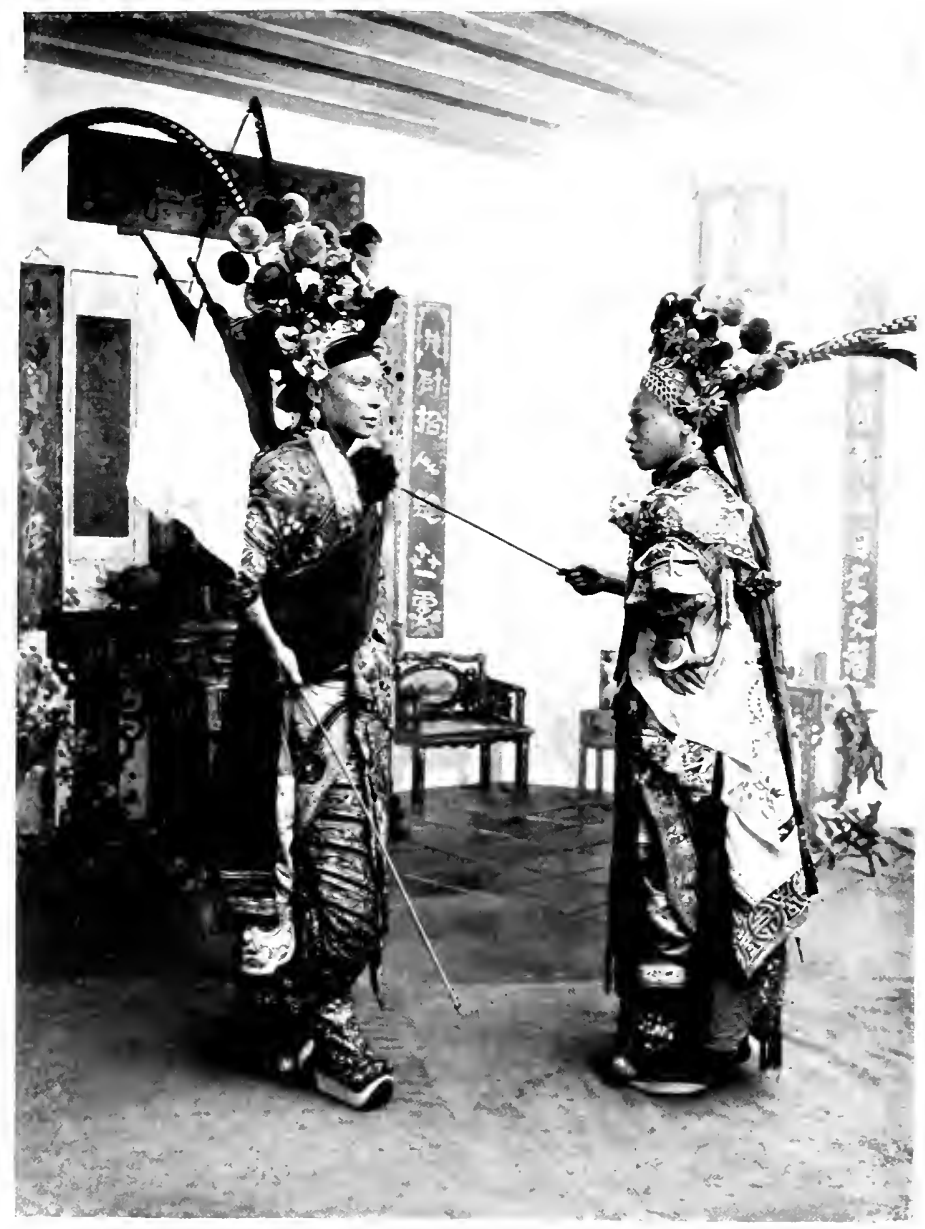

(HIXESE Ar IORC 

responsible for any such advances. Should any one in this country become my enemy, even my own children, all such shall be considered as enemies also of the Company; the Company shall not alter their engagements of alliance, so long as the heavenly bodies continue to perform their revolutions; and when any enemies attack us from the interior, they also shall be considered as enemies of the Company. I request from the Company men and powder, shot, arms large and small, also money for the purpose of carrying on the war, and when the business is settled I will repay the advances. Should these propositions be considered proper and acceptable to the GovernorGeneral, he may send a Confidential Agent to Pulau Pinang to reside; but if the Governor-General does not approve of the terms and conditions of this engagement, let him not be offended with me. Such are my wishes to be made known to the Company, and this treaty must be faithfully adhered to till the most distant times."

There is no ambiguity about these "terms and conditions," and if Mr. Light had exceeded his instructions, if he had made any promises the Company were not prepared to endorse, this was the time to say so.

In forwarding the proposals of the Sultan of Kĕdah, Mr. Light added his own remarks, and, referring to the first condition, he wrote :-

"This article comprehends the principal and only reason why the King wishes an alliance with the Honourable Company, and the treaty must be worded with caution, so as to distinguish between an enemy endeavouring or aiming at his destruction or the Kingdom, and one who may simply fall into displeasure with either the King or his Ministers."

The Supreme Government accepted the grant, and addressed Mr. Light in these terms :- 
“It has been resolved to accept the King of Kedah's offer to the Company of the harbour and island of Pinang. This Government will always keep an armed vessel stationed to guard the island of Pinang and the coast adjacent belonging to the King of Kedah. The GovernorGeneral and Council, on the part of the English India Company, will take care that the King of Kedah shall not be a sufferer by an English Settlement being formed on the island of Pinang."

Further, Sir John Macpherson, then Governor-General, wrote to the Sultan in reply to his letter, made no objection to the conditions, accepted the island, and said:

"Your friendly letter containing a grant of Pulau Pinang to the Honourable Company was delivered to me by Captain Francis Light, the 16 th February, I786. Captain Light also made known to me the requests of my friend and brother, which $I$, having the interest and friendship of my noble friend at heart, have already transmitted to England for the approbation of the King of England and the Honourable English Company. I have likewise ordered a ship of war for the defence of the island and protection of the coast of Kedah."

This also is plain enough, and if any casuist can read two meanings into "the protection of the coast of Kedah," the words have only one for the ordinary intelligence of the plain man.

Mr. Light was authorized to occupy Pinang, and, as we have seen, did so. Only a month later, Mr. Light wrote to the Supreme Government: "The King of Kedah has reason to be afraid of such a tyrant (the King of Siam), and hopes to secure himself by an alliance with the Honourable Company."

Therefore at the very outset the Company knew that the one condition on which the Sultan was willing to cede Pinang was, that his enemies should be the Company's 
enemies, and that they should protect him. They accepted the condition and the protection alike, and their representative in Pinang gave them the particular information that the probable enemy whom the Sultan of Kĕdah had in his mind was the King of Siam. Further proof of these plain facts may seem needless, but in a letter to the Governor-General, dated 5 October, 1786, Mr. Light says : "I returned for answer" (to a letter the King addressed to him concerning an expected invasion from Siam) "that his best policy is to have as little communication as possible" (with the Burmans and Siamese), "but to put his country in a state of defence, and that while the English are here they will assist him if distressed."

The Governor-General, about the same time, seems to have thought it necessary to record, in a minute, his opinion both as regards the independence of the Sultan of Kĕdah and the reasons which influenced His Highness in coming to terms. The Governor-General writes :-

"The grant of Pinang seems, in fact, to have been procured by the influence of the principal officer of the King of Kedah, with a view to secure himself a place of retreat against his numerous enemies, and the ostensible object of the King himself in making the grant, originated in the idea of supporting his own independence by the protection of the English, and his attachment to us will either be strengthened or changed into animosity, as that protection is granted or withheld. This protection, however, cannot be effectually given without involving us in disputes with the Burmans or Siamese, the latter of whom are the most powerful."

This shows that the highest British authority in the East, the one who had authorized the negotiation for Pinang, and accepted the terms without question, fully realized the situation and recognized the independence of Kĕdah. 
Pinang was taken possession of on II August, I786, and it was only in January, 1787 , that the Supreme Government decided to decline the main condition on which the Sultan of Kĕdah had consented to the cession. That decision was communicated to Mr. Light in these terms :-

"With respect to protecting the King of Kedah against the Siamese, the Governor-General in Council has already decided against any measures that may involve the Company in military operations against any of the Eastern Princes. It follows, of course, that any acts or promises which may be construed into an obligation to defend the King of Kedah are to be avoided. If, however, Mr. Light can employ the countenance or influence of the Company for the security of the King of Kedah, consistently with these rules, the Governor-General in Council has no objection to his adopting the measure, strictly guarding against any acts or declarations that may involve the honour, credit, or troops of the Company."

So Mr. Light found himself in the position in which other agents of the British Government have been placed, both before his time and since; but it was rather late for the Company to be particular about its honour and credit.

On 7 May, I787, nearly a year after the occupation of Pinang, the question of monetary compensation was thus raised in a letter from Mr. Light to the Government of Bengal :-

"There is a necessity for coming to some terms with the King of Kedah while the Siamese and Burmans are upon him ; and I have reason to believe that nothing will be acceptable without Government promising the King protection. This place will be subject to many inconveniences without such an alliance as will oblige the King to furnish the Settlement at all times with provisions, and preventing other European nations from settling in 
any other part of his country. Should the Siamese be permitted to take possession of his country, we shall not only find an insolent and troublesome neighbour, but be under the necessity of assisting them in their wars or to go to war with them ourselves. I humbly conceive that it will be easier, and attended with less expense to the Honourable Company, to declare at once the King of Kedah under our protection; little else than the name of the Company will be wanted; the longer it is delayed, the greater will appear the consequence of the island, and the more difficulty there will be in fixing a Settlement. The Danes, the Dutch, and the French have solicited permission to have only a house in Kedah; either of them will promise much, and should the King consider himself aggrieved or disappointed by the English, he may in despair seek for other alliance."

Finding the argument of right, and the faithful observance of promises, of no avail, Mr. Light pleads the cause of expediency, but with no better success. The Company had secured the island, and they knew that no Malay power could dispossess them, and no attempt would be made to do so. Therefore Mr. Light, who was on the spot, could make the best of it, for, to people in Calcutta, the whole affair was of very trifling importance. From Mr. Light's point of view, however, the prospect had quite a different aspect. Pinang was a jungle-island with no means of supporting a population, and they depended upon Kĕdah for almost everything. But the Sultan of Kĕdah, as the Governor-General had foreseen when he wrote "his attachment to us will either be strengthened, or changed into animosity, as that protection is granted or withheld," now knew that he had lost the island, and the other party to the transaction did not intend to give the consideration for which he had bargained. Therefore he was somewhat outspoken in his expressions of opinion, and began to try if he could find some other power on whom more reliance 
could be placed. These proceedings Mr. Light characterized as "duplicity and cunning," and he wrote as follows to Calcutta :-

"I should be extremely sorry, from any ill-grounded apprehension, to put Government to any unnecessary charge or trouble; but it is impossible to say what may be the intentions of the Siamese. If they destroy the country of Kedah, they deprive us of our great supplies of provisions, and the English will suffer disgrace in tamely suffering the King of Kedah to be cut off. We shall then be obliged to war in self-defence against the Siamese and Malays; should your Lordship resolve upon protecting Kedah, two companies of Sepoys, with four six-pounder field pieces, a supply of small arms and ammunition, will effectually defend this country against the Siamese, who, though they are a very destructive enemy, are by no means formidable in battle; and it will be much less expense to give the King of Kedah timely assistance than be obliged to drive out the Siamese after they have possessed themselves of the country."

Mr. Light's appeals, as well to economy as to expediency, fell on deaf ears. Perhaps the Company thought the strength of the force required to maintain the independence of the Sultan, and the open market in Kĕdah, was under-estimated; probably they were beginning to be annoyed by the whole business. At any rate, they were not prepared to supply the two companies of Sepoys, the four guns, and the small arms, and Mr. Light had to continue his negotiations for a money payment, which, in default of protection, the Sultan was not prepared to accept. In July, 1789, after detailing the failure of his various attempts to settle this money question, Mr. Light wrote :-

"Being informed that he did not relish the idea of selling the island, I asked him if he chose to accept four thousand dollars per annum for as long a time as the Honour- 
able Company should continue in possession of the island. To this, after waiting a considerable time, he answered in the negative, at the same time by his letters and messengers he endeavoured to draw a full promise, that the Honourable Company would assist him with arms and men in case an attack from the Siamese should render it necessary. This I evaded by telling him no treaty, which was likely to occasion a dispute between the Honourable Company and the Siamese, could be made without approbation of the King of Great Britain."

In 1793 , seven years after the occupation of the island, the Home Government sent out this definitive instruction: "No offensive and defensive alliance should be made with the Raja of Kedah." Mr. Light died in the latter part of the same year.

We may assume that the political relations between the Company and the Courts of Burma and Siam were such, that the Supreme Government considered it would be inexpedient to support Kĕdah against both her enemies, and thus perhaps induce them, always hitherto at feud, to combine against the Company. Pinang had been secured; seven years of occupation had proved its value, and shown that it could be held, without difficulty, by a small garrison against Asiatics; Mr. Light, the original negotiator, was dead; a treaty, which said nothing about offensive or defensive alliances, had been concluded; the promises of I 785 and I 786 were forgotten or ignored; and the Sultan of Kĕdah might be left to settle accounts with his northern foes, as soon as the conclusion of their mutual quarrels should give them time to turn their attention to him.

As Mr. Light had pointed out, Kĕdah was safe as long as Siam and Ava believed that an attack on Kĕdah might involve a trial of conclusions with the British; but when it was publicly given out, that the assistance for which Pinang had been ceded could not be relied upon, would not in fact, be given, then the fate of Kĕdah became a 
mere question of time, the prospective conqueror, whether Siamese or Burman, a matter of chance.

It is perhaps not necessary to push the matter further, except as regards one point, and that is, how the Sultan of Kĕdah came to consent to two treaties, the first in I79I, and the second in 1800 , without stipulating for that provision which, to him, was the sole reason for the cession of Pinang. Neither document provided for the protection of Kĕdah. By the first engagement the Company undertakes to pay to the Sultan six thousand dollars a year so long as the English remain in possession of Pinang. By the second, called a treaty of friendship and alliancesigned by Sir George Leith, Lieutenant-Governor of Pinang-it is provided, that the Company shall pay to the Sultan ten thousand dollars a year, so long as they occupy Pinang and the strip of territory opposite (now called Province Wellesley), and the Sultan agrees to give to the Company for ever the strip of mainland referred to, which is then roughly defined.

This apparently serious omission on the part of the Sultan need not surprise any one.

If a British officer, accredited by the British Government, makes, during the progress of negotiations with a Malay Raja, any promise on behalf of his Government, it would not occur to the Malay to doubt that such promise would be accepted, and honourably fulfilled by those who sent the envoy. Were such a promise given, and, on the strength of it, territory ceded to the British Government, the acceptance of the cession would be deemed by the Malay the acceptance of the promise, if nothing were then said or written to him, to the effect that his demand could not be complied with:

If, after five years' occupation of such ceded territory, a treaty were concluded, though that treaty did not contain the fulfilment of the promise, the Malay would not consider that the British Government was thereby released from 
performing an engagement, on the faith of which the occupation had taken place.

If such a treaty were then, or afterwards, styled "preliminary," and it were necessary to obtain sanction from a distant Government, to important provisions, it is probable the Malay would be told that this particular request of his was still under consideration, and that, when instructions were received from that high and distant authority, a further and permanent treaty would be concluded with him.

Under these circumstances a Malay Raja, dealing with British officers, would accept their advice.

Lastly, if the British, having been in occupation of a strong position for five years, as the friends of a Malay Raja, proposed to conclude with him a treaty which was not all, or any thing, that he could have hoped for, it is difficult to see what the Malay would gain by refusal.

How all these matters appeared to the Sultan of Kĕdah (successor of him who ceded Pinang to the Company) will be seen from the following letter, addressed by His Highness, on 24 December, I8IO, to Lord Minto, GovernorGeneral of India, as he passed through Pinang on his memorable journey to the conquest of Java :-

"In the year II 199 of the Hegira, in the time of my late father, Mr. Light bearing on the head of submission the commands of the King of England, and the orders of the Governor-General, with various splendid presents, appeared in the presence of my late father, the Râja, and requested in the name of the King of England and of the Governor-General, the island of Penang, for the purpose of repairing their ships-of-war, highly extolling the greatness, splendour, power, wisdom, beneficence, of His Majesty, the prosperity of the Honourable Company and all those connected in the ties of friendship with them ; promising that the King and the Governor-General would assist my father in whatever might be required, and 
would prevent the enemies of Kĕdah engaging in proceedings detrimental to the country. Moreover, that they should pay rent for the island 30,000 dollars per annum, and entered into sundry other engagements. My father, consulting with the Ministers, considering that the neighbouring Burman and Siamese nations were more powerful than Kĕdah and having reflected that the King of Europe (i.e., England) was greater and more powerful than either of those nations, and that by means of the friendship of the English Company, these powers would be prevented from violence or molestation, perceived that it would be very desirable to enter into alliance with the Company, because the Europeans were just and regular in conducting all their affairs, and should the Burman or Siamese powers unjustly attempt violence, the powerful aid and protection of the Company would enable my father to repel the aggression. My father was, therefore, extremely desirous of obtaining the friendship of the Company, under whose powerful shelter and protection, the country might be transmitted to his descendants increased in strength. For this country, being small and deficient in strength, would depend on the power of the Company to repel the attacks of the Siamese and Burmans. My father accordingly, impressed with a sincere desire to obtain the friendship of the Company, granted the island of Penang according to the request of $\mathrm{Mr}$. Light, the Agent for the Governor-General, and a written engagement, containing my father's demands from the Company, was given to Mr. Light, for the purpose of being forwarded to the Governor-General. After some time, Mr. Light returned to settle on the island, bringing some Sepoys, and he informed my father that the Governor-General consented to his requests, and had sent people to settle on the island; that the writing from my father had been transmitted by the Governor-General to Europe, for the purpose of receiving the royal seal and 
sanction, and that it would be returned in six months. My father accordingly granted permission to proceed to settle on the island of Penang, and sent his people to assist in the work, and his officers to protect them from the pirates in the commencement. My father having waited some time, at the expiration of the year, requested the writing from Mr. Light, who desired him to wait a little; at the end of six years no authentic writing could be obtained; he received 10,000 dollars per annum, but Mr. Light refused to fulfil the remainder of his engagements, and in consequence of my father insisting upon having a writing, agreeably to his former stipulation, a misunderstanding arose between Kĕdah and Penang, after which a new treaty of alliance was concluded. Since that time, many Governors have been placed over Penang, but my father was unable to obtain a writing either from Europe, or from the Governor-General. In the year I2I 5 , my father left the government to my uncle, at which time the Governor of Penang, Sir George Leith, requested the cession of a tract of land on the opposite shore, alleging that the island being small, the Company's people were distressed for procuring timber, and the raising of cattle. My uncle being desirous of removing the uneasiness, granted a tract (of which the boundaries were defined) accordingly, placing entire dependence on the power of the Company to protect and defend him against his enemies, and Sir George Leith made a new treaty, consisting of fourteen articles, and constituting the two as one country. This, and the former treaty, are inscribed on the Company's records. During the whole government of my father and uncle, no injury or molestation of any consequence had been sustained, nor has any one ever offered to send my letter of supplication to the King or to the Governor-General. I consequently desisted, and only communicated with the several Governors of the islands in matters relating to the two countries, but no 
certain arrangement from Europe could be heard of, nor could I obtain any assurances on which I could depend.

"Moreover, so long as I have administered the Government of Kĕdah, during the time of the late King of Siam, his proceedings were just and consistent with former established custom and usage. Since the decease of the King, and the accession of his son to the throne, in the year I I I , violence and severity have been exercised by the Siamese against Kĕdah, in demands and requisitions exceeding all former custom and usage, and which I cannot support for a length of time. The Râjas of Kĕdah have been accustomed to submit to the Siamese authority in matters clearly proper and consistent with the established customs of the governments, for the sake of the preservation of the country, being unable to contend with Siam, from the superior number of their people. During my administration, their demands have been beyond measure increased, and heavy services have been required of me, inconsistent with the custom of the country. These, however, I submitted to as far as I have been able, for the sake of the people, and to prevent the danger of a rupture with them; how many services, unprecedented in former years, have I not performed, and what expenses have I not incurred in carrying into effect their requisitions! Nevertheless, I cannot obtain any good understanding with them, nor any peace, nor any termination to their injuries and oppressions. They no longer confide in me, and seek to attach blame, alleging that I have joined with the Burmans, with whom this year they have made war, and their intention is to attack Kĕdah for the purpose of reducing the country under their government. I have in vain endeavoured to avert the enmity of Siam, but without any appearance of success. I have made known to the Governor of Penang, every circumstance with relation to this country and Siam, and have requested his advice and the assistance of 
the Company, on which my father relied, because the countries of Kĕdah and Penang are as one country and as one interest. When, therefore, Kĕdah is distressed, it cannot be otherwise with Penang. The Governor advised me by all means to avoid coming to a rupture with Siam, alleging that it was not in his power to afford me assistance, for that the Supreme Government in Europe had forbidden all interference in the wars of the neighbouring powers. Perhaps this would be improper with respect to other countries, but Kĕdah and Penang are much distressed by the labours necessarily imposed to avert the resentment of Siam, and every exertion on my part has been made to prevent coming to a rupture with that power, but I was unable to submit to demands exceeding all former precedent, which induced me to apply to the Governor of Penang for the Company's aid to enable me to repel their demands, for my father having transmitted to me his friendship and alliance with the Company, it would be otherwise a reflection upon the power of the King of England, who is accounted a Prince greater and more powerful than any other. I conceive that the countries of Kĕdah and Penang have but one interest, and perhaps the King and my friend may not have been well informed, and in consequence the Governor of Penang has not been authorised to afford assistance, and that should they be acquainted therewith, they would consider it impossible to separate the two countries. In consequence, I request my friend to issue directions, and to forward a representation to the King and to the Honourable Company, of the matters contained in this letter. I request that the engagements contracted by Mr. Light with my late father, may be ratified, as my country and I are deficient in strength; the favour of His Majesty the King of England extended to me, will render his name illustrious for justice and beneficence, and the grace of his Majesty will fill me with gratitude; under the power and 
Majesty of the King, I desire to repose in safety from the attempts of all my enemies, and that the King may be disposed to kindness and favour towards me, as if I were his own subject, that he will be pleased to issue his commands to the Governor of Penang to afford me aid and assistance in my distresses and dangers, and cause a regulation to be made by which the two countries may have but one interest; in like manner I shall not refuse any aid to Penang, consistent with my ability. I further request a writing from the King, and from my friend, that it may remain as an assurance of the protection of the King, and descend to my successors in the government. I place a perfect reliance in the favour and aid of $m y$ friend in all these matters."

I have not succeeded in ascertaining what answer was sent to the Raja, but that letter, addressed to the highest authority then known to the Malays, would appear to the Raja to exhaust his efforts at redress. An adverse reply would be conclusive of the futility of further representations.

It was not till I82 I that the Siamese found leisure to attend to Kĕdah; then the attack was sudden, the cruelties perpetrated barbarous to a degree, and the rout of the Malays complete. Without the slightest warning a large fleet of boats loaded with Siamese suddenly appeared in the Kĕdah river and landed at a fort, where they were civilly received. Several of the principal Kĕdah chiefs were present, and a large number of the Siamese having landed, their leaders threw off the mask, told the chiefs they had come to seize them, and they must submit to be bound. The Malays at once shouted, "We are betrayed, let us attack them furiously," and fell upon the Siamese, but were immediately cut down. The Siamese then proceeded up river, carrying fire and sword wherever they went; killing the men, outraging the women, pillaging, torturing, destroying all over the land. The Raja of 
Kĕdah himself escaped with the greatest difficulty, and after infinite privations made his way into Province Wellesley and thence by water to Pinang, where he was hospitably received and well treated by the Governor. Not satisfied with their work in Kĕdah, the Siamese pushed on to Perak, attacked and subdued the people of that State, and made preparations to continue their conquests in Selangor. The Sultan of Selangor was, however, prepared for them, and, in face of his reputation and determined attitude, the Siamese decided to withdraw their forces and returned to Ligor, the Southern Siamese State, from which they had started. The Sultan of Kĕdah died in exile, while his favourite son was captured and sent in bonds to Siam. The principal minister was also captured, and after being kept in chains in Kĕdah for a long time, was carried away and poisoned on the road to Senggôra.

These particulars and an immense number of other details were collected and published in the form of a pamphlet, under the authority of the Government of Pinang, by Mr. John Anderson, secretary to that Government, in the year I 824. Immediately after its publication the pamphlet was recalled and so carefully suppressed that Mr. Anderson was obliged to give his word of honour that he had not retained a single copy. One copy did, however, escape, and was republished in a Straits newspaper in 1835 ; this publication having become equally scarce, the paper was reprinted, in 1854 , in the Journal of the Eastern Archipelago, of which very few complete copies are now in existence.

The only question which remains is whether Kĕdah, in I 786, owed any allegiance to Siam, or was subject to the control of that kingdom. It would be easy to give many proofs to the contrary, but one is sufficient. The East India Company negotiated with the Sultan of Kĕdah as an independent ruler in 1786 , and made an arrangement 
with him for a cession of territory. The Company made treaties with the Sultan to confirm this arrangement in I79I, and again, in I800, for the cession of a considerable territory on the mainland and it was not till I82 I that the Siamese made an unprovoked and treacherous attack on the Malay State. These facts seem to prove the Sultan's absolute independence.

In the early history of Pinang there is one point of special interest to which reference should be made. It has been customary to give Sir Stamford Raffles the credit for insisting that Singapore should be a free port from its very foundation as a British Settlement. That birthright has been the main source of the extraordinary prosperity of this great eastern market, and no doubt Sir Stamford Raffles was responsible for this policy in regard to Singapore. It was not, however, a new idea in the British Settlements in Malaya in the year 1819 , for when Raffles was still in the nursery, Sir John Macpherson, then Governor-General of India, wrote as follows to Mr. Light, in regard to Pinang, only six months after the occupation of that island :-

"If the situation is favourable, the merchants will find their advantages in resorting with their goods to it, and as an inducement to them, we desire you will refrain from levying any kind of duties or tax on goods landed or vessels importing at Prince of Wales Island, and it is our wish to make the port free to all nations."

A year later another Governor-General asked Mr. Light how he proposed to meet the growing expenses of maintaining the Pinang administration. Mr. Light took six months to consider the matter, and then suggested, amongst other taxes, the following duties :-

5. That a duty of 4 per cent be levied upon all India goods imported on foreign vessels.

6. That a duty of 4 per cent be levied upon all goods 
imported on Choolia vessels not immediately from any of the Company's Settlements.

7. That a duty of 6 per cent be levied upon all China goods without distinction.

8. That a duty of 6 per cent be levied upon all tobacco, salt, arrack, sugar, and coarse cloths the produce or manufacture of Java or any other Dutch possession to the eastward.

9. That a duty of 6 per cent be levied upon all Europe articles imported by foreign ships unless the produce or manufacture of Great Britain.

Mr. Light evidently did not like his own proposals, for he added :-

"To levy a general duty on all goods which come to this port would defeat the intention of Government in making remittances to China by the barter of the manufactures of India for the produce of those countries. The present situation of the surrounding kingdoms, distracted by foreign and civil wars which deprive their inhabitants of the privilege of bringing the produce of their lands to this port, added to the various impediments thrown into the way of the English trade by the Dutch, who prevent the China junks and the Malay and Bugis prows from passing Malacca, while by threats they cause some of the Malay States and by force oblige others to desist from trading with the English, are obstacles too great to admit of the levying with success any general duties. ... Few colonies, I believe, in America or the West Indies were capable of making returns in the course of seven years from their settling, and this island, it appears to me, ought to be treated as a colony, and the expense of maintaining it drawn from the lands and not from the trade, which should be encouraged as much as possible while subject to so many inconveniences, to the end that the export of manufactures of the Company's territories in India may 
be extended, and the remittances to China by the sale of these manufactures increased."

The approval of Government was given to Mr. Light's proposals for raising revenue, but the effect of the import duties was so unsatisfactory that they were abolished one by one, and Pinang became again, and remains to this day, a free port to all nations as originally decreed by Sir John Macpherson.

While following up this record of the foundation of Pinang, so little flattering to our national pride, we have got far beyond the date (1795) when England first entered into possession of Malacca, and have even passed the occupation of Singapore in 1819 . The reader will understand that it is practically impossible to keep in constant touch with three Settlements like Malacca, Pinang, and Singapore, none of which were in our possession in 1785 . One became ours in 1786 , and is so still ; one we captured in 1795 , restored in 1801 , occupied for the second time in 1807 , gave up in 1818 , and again took it over in March, 1825, in exchange for Bencoolen and other ports in Sumatra, while we occupied the third in 1819 and have kept it ever since. For a time these Settlements were rivals, under different and independent control, but all subject to a supreme authority in Calcutta; then they became united as one Presidency, under a Government which itself must needs change, from the Honourable East India Company to the Government of India. Finally they were severed from Indian control, took rank as three Settlements forming one Crown Colony, under a governor, who was also commander-in-chief and vice-admiral within the borders of his own administration.

To maintain continuity it is necessary to return for a moment to Malacca. This place surrendered, in August, I795, to the expedition under command of Captain Newcome, of the Orpheus, and Major Brown, of the East India Company's Service. From that time till its second 


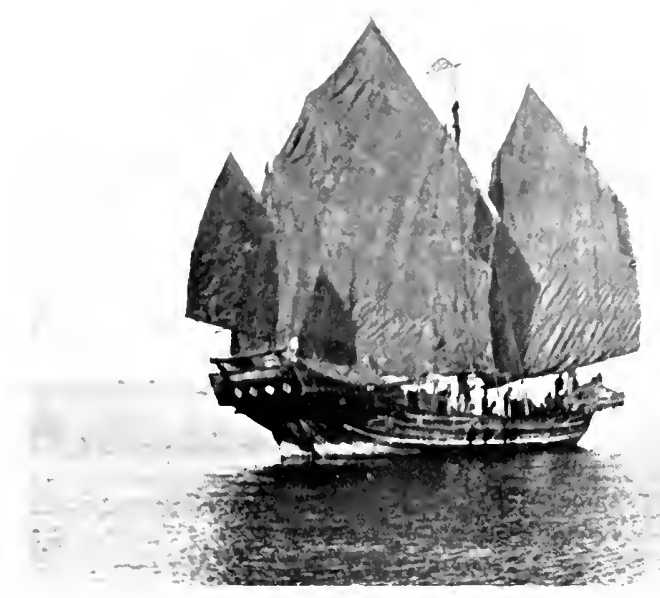

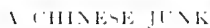

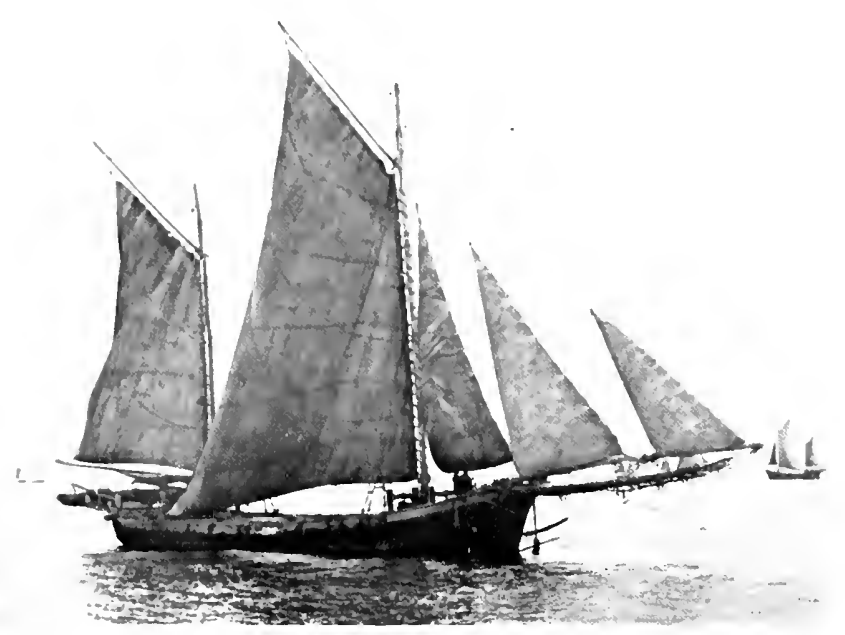

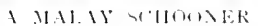



restoration to the Dutch in I8I8, only two occurrences need be mentioned. In 1807 , the ancient fortifications of Malacca, built by Albuquerque and strengthened by the Dutch, valued by the British Resident, Colonel Farquhar, at 700,000 Spanish dollars-that is, about $£ 150,000-$ were destroyed. One writer places the cost of destruction at 260,000 rupees, and another at $£ 70,000$. In either case it was enormous, perfectly needless, and an act of unforgivable vandalism.

The other notable event, during the second occupation of Malacca by the British was that Lord Minto chose this place as the rendezvous for the British force which captured Java in I8I I. It was there that Raffles met the Governor-General ; there that plans were discussed and all preparations made, and from there, on the strong advice of Raffles, the fleet sailed by a route which the sailors considered risky and unwise, but the event proved that Raffles was right. In the Stadt House at Malacca there hung until recently a very interesting portrait of Lord Minto, which was probably painted about this time, for the background is unquestionably the old town of Malacca, but little changed from the appearance of the place as seen to-day.

None of the many English writers who have dealt with Malacca and its changeful and romantic history, appear to mention this eventful gathering for the conquest of Java. Less than a year after the first occupation of Malacca by the British, there was born there a Malay boy, named Abdullah, the son Abdulkadir, who in time became a Malay writer in the office of Colonel Farquhar, the Resident and Commandant. When this boy was about fifteen years of age, Raffles and his wife came to Malacca, to prepare for the arrival of Lord Minto. Raffles was soon attracted to the Malay boy, and made great use of him as a scribe. Thirty years later, at Raffles' request, Abdullah wrote a book of over four hundred pages, called the Hikaiat 
Abdullah, Abdullah's history, in which the writer tells, with great accuracy and detail, the story of his own life. Raffles inspired in the boy a very strong admiration and affection, and three chapters of the book are devoted to a minute description of Raffles' proceedings in Malacca; the arrival of the transports with the troops; the landing of the men, guns, and horses; the camp life and the amazement of the good people of Malacca at the sight of so many strange warriors with their peculiar caste prejudices. He describes a regiment of three hundred Indian horsemen, who rode without reins in order that they might be able to use the very numerous weapons with which they were armed, and tells how he went to see them at exercise ; and when the show was over, the English officer in command, who was quartered near the ground, disdained to ride through the gate of the garden surrounding his house, but preferred to jump his horse over the fence, to the great delight of an immense crowd of spectators. Abdullah says that this delightful person-whose name alas! is lost-invariably came on to parade over the fence and returned by the same way-conscious, no doubt, of the admiration he excited. There need be no shadow of doubt as to the performance, but Abdullah says the fence was seven cubits high, and one may be permitted to wonder what was the length of the cubit. Abdullah's inquiring mind impelled him to make a personal visit to the camp of these horse-soldiers, and this is the account of the visit:-_" I asked them, "Where did the English bring you from?' And they replied, 'We are all from Delhi, the Nabab's men. The English came there and asked for men, and the Nabab gave three hundred of us. There are thousands of our companions still left there, all horse soldiers like ourselves.' Then I said, 'What are your wages per month?' And they answered, 'The Nabab pays us three hundred Sicca rupees a month, per man, and the English pay us the same amount, and they have 
promised us that if they take Java, they will give us a present in addition to our wages." " No doubt these Indian warriors could not resist the temptation of magnifying their importance by enormously exaggerating the rate of their pay.

A Malay, born in the Malacca of I796, after nearly three hundred years of European domination, is not quite the same being as a Malay whose people never saw a white face ; his point of view is different, but still it is interesting, and I have therefore translated the following passage from a chapter which Abdullah calls " Concerning Lord Minto." The Malay historian describes the arrival of the GovernorGeneral in "a very swift black ship, low in the water, flying a special flag at the main." He tells of the landing, the quantities of troops paraded, the salutes, the bands, the whole populace in attendance; and here, evidently written from the heart, is Lord Minto, as he appeared to one of the vast crowd of Malays who respectfully welcomed His Excellency to the Malacca of early Malay enterprise, the Malacca of Albuquerque, the Malacca which, with the departure of this great expedition, was to sink into the obscurity of those whose day is done.

"When I saw Lord Minto, and how he bore himself, I was amazed. For I had imagined to myself what he would be like, his height, his appearance, his dress. Then I thought of the Malay proverb which says, 'fair fame is better than a fine appearance,' and I bit my finger. To me he appeared to be a man of middle age, with a spare figure, charming manners, and a pleasant countenance. I said to myself that I did not think he could lift so much as $30 \mathrm{lbs}$. He wore a dark coat and dark trousers, and beyond that there was nothing to remark in his dress. And all the great men who were there to welcome him stood a long way off; and not one of them dared to offer his hand, they only raised their hats and perspired. Then the commander of the soldiers shouted an order, and every 
musket was brought to the salute. And as he (Lord Minto) came forward, he looked to left and right, and bowed to either hand, and then walked slowly through the guard of honour, while the guns kept thundering the salute, and he never ceased raising his hand in courteous acknowledgment of salutations. I could not see in him the slightest trace of hauteur or self-importance, he simply bowed without affectation, and regarded every one pleasantly. And as he came to a great crowd of people they saluted him ; and he stopped for a moment and raised his hand, to acknowledge the welcome of all those poor folk - Chinese, Malays, Tamils, and Eurasians-and he smiled as he returned their greeting. How the hearts of all God's servants expanded with joy, and how the people prayed for blessings on Lord Minto, when they saw how he bore himself, and how well he knew the way to win affection. Then I had a momentary hesitation, because I remembered the Malay proverb which says: 'Even though a snake passes close by the root of the tree which contains a cure against his bite, he does not lose his venom.' There is also a Chinese proverb which says : 'It is not the water in the full bucket which splashes about and makes a noise, it is that of the bucket which is only half full.' And so it is with great men. In these days the servants who wait at table have no rank, but their arrogance is lofty as Heaven. If a poor man, like myself, bids them good day, even three or four times, they pretend they do not see him. How much more is this the case when they have arrived at carriage rank! As children say, 'If you give a monkey a flower he has no idea what to do with it, he simply pulls it to pieces and drops it on the ground.' Moreover, Malays say, 'However high the white padi bird may soar, he perches eventually on the back of a buffalo'; and however great men may become, in the end they go down into the dust.

"I make, however, ten thousand apologies to the great 
man of whom I am writing. Let no one who reads this book think that I have written in envy, or depreciation of any one ; but we live on earth for a day or two, and if we do well, people speak well of us, if evil, the opposite. The Malays say: 'A tiger dies and leaves his stripes; an elephant dies and leaves his bones; a man dies and leaves his name, to those who come after him.' But to get back to Lord Minto. After waiting a moment, to return the salutations, he walked on slowly, bowing to the people, until he reached the Stadt House and entered it. Then all the great people of Malacca, and all the great amongst those recently arrived, went to meet him; and I noticed that amongst all those distinguished people it was $\mathrm{Mr}$. Raffles who was bold enough to approach him, the others sat a long way off. A few moments later every one who had entered and met the Governor-General withdrew, and returned to their own quarters. Then the troops fired three volleys in succession, and they also returned to their camp." 


\title{
CHAPTER IV
}

\section{SINGAPORE-EARLY HISTORY- STAMFORD RAFFLES}

\begin{abstract}
$\mathrm{N}$ incident, which must always be connected with the history of Malacca, has introduced Raffles as the leading figure in the final arrangements for the dispatch of Lord Minto's expedition for the conquest of Java.
\end{abstract}

Stamford Raffles, who has written his name for all time in the book of great English Empire builders, was the son of the master of a West Indiaman, and the boy was born on board ship on 5 July, 178I. After a very brief schooling Raffles, at the age of fourteen, became a clerk in the offices of the East India Company in Leadenhall Street, and when only twenty-four he was sent to join the Pinang establishment as an assistant secretary. Raffles began to learn Malay on his voyage to the East, and from the moment he reached Pinang he devoted all his leisure to the study of the language and people with whom his lot was cast, and for whom he appears to have conceived a great sympathy and affection. This characteristic not only won him the confidence of the Malays, but through the instrumentality of Dr. Leyden, who met him in Pinang, it brought his name prominently to the notice of Lord Minto, and laid the foundations of that knowledge of Malay affairs which so soon carried him to the front and established his fame as Lieutenant-Governor of Java, and later as the founder of Singapore. 
About I 807 Raffles visited Calcutta, where he was received with great kindness by the Governor-General, and returned to the Straits with the title of GovernorGeneral's Agent in the Eastern Seas. This appointment gave him a position of semi-independence, and enabled him to collect all the information necessary to determine the Government to dispatch an expedition for the capture of Java. We have seen how the force, six thousand British and six thousand Indian troops, in ninety vessels, rendezvoused at Malacca, from whence they sailed on II June, I $8 \mathrm{I}$, under the personal direction of Lord Minto with Raffles as his chief Intelligence Officer. The army landed near Batavia on 4 August, occupied that place on the 9th, and on the $25^{\text {th }}$ fought the decisive Battle of Cornelis, where we lost five hundred men, and the enemy, under General Janssens, four thousand, while five thousand were taken prisoners.

Six weeks later Lord Minto returned, leaving Raffles as Lieutenant-Governor of the newly conquered, populous and fertile island with all its dependencies. It is certainly remarkable that Raffles, with no family or other influence, and little education except what was due to his own industry, should, at the age of thirty, after only six years in the East, have found himself in a position of such honour and responsibility. The fact is immensely creditable to Raffles, and not less so to the discernment and sound judgment of the GovernorGeneral.

It cannot but be interesting to have a description of such a personality at such a moment; and the interest is all the deeper when the picture is drawn by one who was daily and hourly studying his subject with the alert intelligence of a bright Malay boy. Reference has been made to Abdullah's history, and this is Raffles, in I8II, drawn by Abdullah's pen. I have only put the writer's words into English:- 
"Now as to the appearance of Mr. Raffles, I noticed that he was of medium height, neither tall nor short, neither stout nor thin. His forehead was wide, a sign of great power of organization, and the front of his head was large, a sign of ability. His hair was light, a sign of courage ; his ears were broad, to enable him to hear everything; his eyebrows were strongly marked; he had a cast in his left eye; his nose was thin, the sign of a clever talker: his tongue was persuasive, his mouth large, and his neck of a good length. His complexion was not excessively fair; he had a broad chest, a small waist, and feet of medium size. When he walked, it was with a slight stoop. As to his manner, he seemed generally to be absorbed in thought. He was extraordinarily courteous, with a pleasant face and word for every one, of every station, and a wide sympathy for all men. He was generous to the poor. He was very clever in repartee, and whenever he spoke it was always with a smile. He had a great power of getting out the details of long past events, and he never let a matter go till he had got to the bottom of it. He preferred quiet places, and he was for ever writing or reading books. Whenever he was studying or talking, it did not matter who came to his house, he would not see them till he had finished. I also observed that he did everything with method; taking each in its turn, and never jumbling up one with another. I noticed also that in the evening, when he had had his tea with his friends, there were always ready, on a large table, pens, ink and paper, and two lighted candles. And when he was tired of walking up and down the room, he would lean right down on the table and shut his eyes like one weary and asleep. Two or three times I thought he was asleep, when suddenly he would start up and write, and then return to his former attitude. He would go on like that till eleven or twelve o'clock when he went to bed. That was his daily custom, except when he had friends. When he woke in the morning, he would read what he had 
written the night before, walking backwards and forwards all the time. Out of ten pages which he read, he would give three or four to a clerk to copy into a book; the rest he would tear up and throw away."

This is not the place to speak of the remarkable work done by Raffles during his five years in Java; but when he left the island in 1816 , it was to go to England for a much-needed rest. In $\mathrm{I} 8 \mathrm{I} 7$ he was appointed LieutenantGovernor of Bencoolen, in Sumatra, a miserable out-ofthe-way place, to which he was sent by those who feared his restless energy. Raffles reached Bencoolen in March, I818, and in April he was already insisting upon the necessity of finding a suitable spot on which to establish a British Settlement, to counteract the aggressive and exclusive policy of the Dutch.

The spot selected was the island of Singapore, at the southern extremity of the Straits of Malacca, and there a preliminary treaty was concluded with the local Malay chief, the Dato Tĕmĕnggong of Johore, on 30 January, I819, and a more formal document was drawn up on 6 February, 1819, between Sir Stamford Raffles, on behalf of the Honourable East India Company, and Sultan Husein of Johore and the Dato Tĕměnggong. How Singapore came to be chosen for the British Settlement and the steps which actually led up to the making of the treaties are questions which have been greatly argued. The interest which now attaches to these matters has grown out of the succession of controversies raised by different writers on the subject. The generally accepted version is that Raffles, having been to Calcutta and persuaded the Supreme Government that his view of the situation was correct, returned to Bencoolen with authority to select and occupy, at the southern end of the Malacca Straits, a position which would act as a barrier to Dutch influence and open the door to the extension of British trade in the Malay Archipelago. At this very 
time Colonel Farquhar, the Resident of Malacca, was about to return to England, as Malacca was on the point of being handed back to the Dutch under the terms of the Treaty of Vienna. Whilst in Malacca Colonel Farquhar had been under the Government of Pinang, and, by their instructions, he had attempted to secure a suitable position for a British Settlement on the island of Bentan, in the neighbourhood of Singapore. This attempt had failed (owing to the action of the Dutch, who had seized Rhio), and the Pinang Government abandoned the scheme as hopeless. Colonel Farquhar had, however, discharged his duties to the satisfaction of the authorities in Calcutta, and they, thinking that his experience and services would be very useful to Raffles, wrote to Colonel Farquhar directing him to postpone his departure, and to place himself at the disposal of Raffles for the selection of a new station which, when occupied, would be placed under his charge.

Raffles was also entrusted with a mission to Achin, and his instructions were to deal first with that question and then proceed to the selection of the new Settlement. Raffles, apparently at the instance of the Government of Pinang, determined to let the Achin matter wait and immediately sailed down the Straits, picking up Colonel Farquhar somewhere-certainly not at Malacca-on the way. Raffles and Farquhar then visited and abandoned in turn Siak, on the east coast of Sumatra, and the Karimun Islands. Disappointed with these places, they sailed for Johore and, either by accident or design, landed at Singapore. Finding this place almost uninhabited and with great natural advantages, Raffles immediately determined to acquire it, and to that end made a preliminary arrangement with the local chief. This Malay chief was the Dato Terměnggong of Johore, a high officer of the Sultan of Johore, who asserted that he had certain special rights over Singapore, though by his action, and by his other 


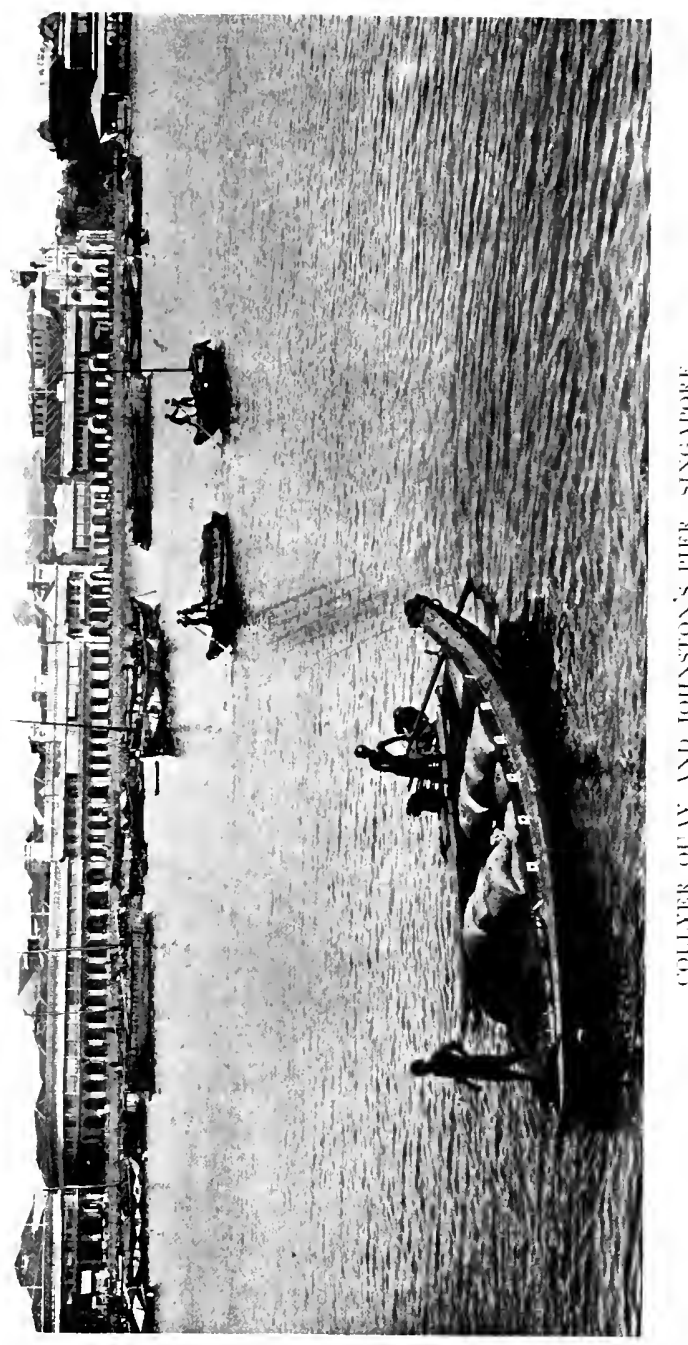



statements to the English officers, it was clear that any arrangement made by him must be subject to the approval and confirmation of the Sultan of Johore.

At this time, owing to intrigues and a variety of circumstances needless to relate, the younger of two brothers had, on the death of their father and during the temporary absence of the elder and rightful heir, been persuaded to allow himself to be proclaimed Sultan of Johore. It was also known that this younger brother was under the influence of designing people with Dutch sympathies. Raffles, therefore, sent at once to Rhio for the elder brother, Tunku Husein, otherwise called Tunku Long, and on his arrival in Singapore he was duly proclaimed Sultan of Johore. His title and authority were formally recognized by Raffles, on behalf of the East India Company, and a new treaty was made on 6 February, I8I9, between Raffles on the one hand and the Sultan Husein and the Termenggong on the other, by which the Malays granted to the British Government the right to settle on the island.

A further arrangement, dealing with administrative questions, was entered into on 26 June, 1819 ; yet another agreement was made in June, I823; and the final treaty, by which Singapore is now held, is dated 19 November, I 824 .

All this seems plain and simple enough, but seeing the immense success of Singapore under English rule, its rapid rise, its great natural advantages, its unique position and immense importance to the Imperial Government, the interest of many intelligent men who had a hand in its advancement was, years ago, aroused to ascertain and record the exact facts of its occupation as a British Settlement. In the course of the inquiries which began then and have continued spasmodically ever since, some claim has been made to give Colonel Farquhar at least a part of the credit for choosing Singapore as the new English 
station. That claim was asserted by Colonel Farquhar in his lifetime, but it found few supporters, and the theory generally accepted is the one just stated. To support it there are a number of official documents, a few statements in letters from Raffles-not very definite or positive statements-added to the general belief that Raffles alone was responsible for the selection of Singapore, as well as for the far-seeing and broad-minded policy on which the place was nurtured into greatness. A stronger proof than anything before advanced is probably to be found in the original Malay treaty, lately unearthed by the diligent inquiries of Mr. C. B. Buckley, a photographic copy of which is to be found in his interesting book, An Anecdotal History of Singapore. This is the treaty of 30 January, 1819, between Sir Stamford Raffles and the Dato Tĕmĕnggong of Johore, signed by Raffles and sealed by both the parties.

To those who have no special interest in the Straits the question may seem to be of small importance, but it is impossible to leave it without drawing attention to the fact that Abdullah, who in his History gives several most carefully written chapters to the search for a place on which to found a new British Settlement, and to the actual occupation of Singapore, not only does not mention that Raffles was present when the expedition landed at Singapore, but distinctly and several times says he was not there!

Some of these chapters were translated and published many years ago, and those writers who have referred to them, in connexion with this question, were satisfied to dismiss Abdullah's record with the statement that he admits he only went to Singapore four months after its occupation, and therefore that his account is all hearsay. A careful examination of the original Hikaiat Abdullah leaves the reader in doubt on this point, for several reasons which need not be gone into here. It might be argued 
that the visit paid to the Settlement, when it was four months old, was not the first; but if it was, then Abdullah, long before mentioning that fact, has recounted several personal adventures of his own in Singapore which must of necessity have occurred subsequent to his arrival, and should have so appeared in his book. If there were no evidence available beyond Abdullah's History, it would be difficult to believe that Sir Stamford Raffles was present when Colonel Farquhar landed at Singapore. The preliminary treaty of 30 January, I 819 , with the Tĕmĕnggong, the treaty of 6 February, I8I9, with the Sultan and Tĕměnggong, both signed by Raffles, and the instructions which Sir Stamford addressed to Colonel Farquhar on 6 February, 1819, settle this question absolutely in a contrary sense.

Raffles' knowledge of Malay history, or tradition, would have made him acquainted with the fact that, six hundred years earlier, ages before Portuguese or Dutch had been heard of in the Far East, Singapore had been a thriving, populous city, the foremost in the Archipelago. Yet we know that Raffles' first idea was to found a station in the Straits of Sunda, and he actually did attempt to create such a place, but it was a failure. When he sailed down the Straits of Malacca in January, 1819, and met Colonel Farquhar, it is probable that Raffles may have had Singapore in his mind as a suitable spot for his settlement, if he found nothing better. Colonel Farquhar, who had been some years at Malacca, where he had made friends with Tunku Husein, and probably discussed with him the possibility of finding a good station in the vicinity of Johore, ought to have known the neighbourhood much better than Raffles. Moreover, Colonel Farquhar had already visited Rhio at least once, and that journey must have taken him past the Johore side of Singapore, both going and returning. Siak was useless, and the Karîmun Islands, which seem to have been the suggestion of Colonel 
Farquhar, were also unsuitable. Raffles' instructions from the Supreme Government were, that he was to negotiate for a firm position at Achin, in Sumatra, and endeavour to establish "a station beyond Malacca." The port of Rhio was specifically named, and failing that place, on account of its being previously occupied by the Dutch, Raffles was directed "to endeavour to establish a connexion with the Sultan of Johore," his instructions adding: "The position of Johore renders it nearly, or perhaps entirely, as convenient a post for our purposes as Rhio." It is therefore probable that the expedition was cruising along without a definite destination when, passing Singapore, the explorers decided to put in there and consult the Dato Těměnggong, who had made Singapore his headquarters since I8II. The splendid roadstead and other natural advantages once seen, there would be no further doubt, and Raffles lost no time in coming to terms with the Malay chief whom he found on the spot; though he realized at once that, to secure his title, he must have the consent of the Sultan of Johore. Tunku Husein's presence was a necessity; he was summoned from Rhio, proclaimed Sultan of Johore (a title to which he had an absolute right), and the more formal treaty of 6 February was then concluded. Raffles immediately sailed for Pinang and Sumatra to carry out his mission to Achin, and report to the Governor-General, the Marquis of Hastings; while Colonel Farquhar was left in charge of the infant Settlement. The exact facts are not of real importance; but it is more than probable that Raffles, by good luck and without assistance from others, selected Singapore as the site of his avowedly anti-Dutch proBritish Station. The idea of such a post was Raffles' own; for it is probable that his instructions were drafted on information supplied by himself, and in that case it is noticeable that Rhio and Johore are indicated as likely places, but not Singapore; he went South with the 
express object of carrying out his favourite scheme before his masters could have time to change their minds, or his rivals to anticipate his design. Colonel Farquhar was only there to help his senior, and it is certain that, if there had been no Raffles in I8I9, there would have been no British Singapore to-day.

The recognition of the value of Singapore island to meet all the requirements of the situation, and its acquisition from those entitled to dispose of it, were very simple matters compared with the difficulty of retaining a hold upon it and of convincing the Governor-General, the Board of the East India Company, the Secretary of State for Foreign Affairs, the British Government, and the British people, that the island must on no account be given up. The Marquis of Hastings, under whose directions Raffles started with the special intention of occupying a position in Johore, wrote to the Governor of Pinang, less than two months later, to say that Raffles was not justified in sending Major Farquhar eastward in the face of a Dutch protest, and "if the post has not yet been obtained he is to desist from any further attempt to establish one"! Fortunately the post had been obtained, and the weathercock-mind of the Governor-General veered round once again. The members of the East India Board were furious, and the ministers of the Crown were "excessively angry." Indeed, had it not been for Raffles, his insistence, his arguments, his labours to secure supporters for his scheme, it is certain that Singapore would have been abandoned by the British, and equally certain that it would now be a Dutch possession. Raffles made it, and Raffles saved it; but even he alone could not have kept the place if the interest of the English mercantile community had not been aroused, and they had not exerted their influence to retain Singapore. Raffles' genius and patriotism were rewarded by endless worry, by the disapproval of his employers, and by public censure from his country's ministers. 
The jealousy of the Pinang Government (which had failed in its own attempt to secure a Settlement at Rhio), even tried to wreck Raffles' scheme; they refused to render assistance to Colonel Farquhar when he feared an attack; suggested that he ought to withdraw all his people rather than risk an engagement, and advised the Calcutta authorities to abandon Singapore to the Dutch!

Time, mercantile influence, and the ever-growing success of the new station won the day. But fate seems to have been strangely malign, for with the assurance of the certain prosperity of his Settlement came the end of Raffles' career.

Raffles, the most assiduous worker, the most en thusiastic collector of everything which could advance the cause of knowledge and of science, sailed for England from Bencoolen in a small vessel called the Fame on 2 February, I824. The same evening the vessel caught fire, and those on board had barely time to get out of the ship into small boats before she was nothing but a mass of flames. Sir Stamford and Lady Raffles and the rest of those saved from the Fame got back to Bencoolen with no little difficulty, but the fruits of many years' work in Sumatra and Singapore-the notes, the maps, the books, the collections of every kind, including many wild animals and birds-had gone utterly and for ever. Raffles himself was already broken in health; he had lost his first wife in Java and three children in Bencoolen, and when, two months later, he finally left Sumatra and the Far East, he had exhausted his energies in the service of the Company and his country. Two years of further worry in England, of charges and claims by his late employers, resulted in his death at the age of forty-five. Comparatively few people in England know the name of Stamford Raffles or what it stands for ; and yet to him we owe the possession of Singapore, the Gate of the Farther East, a naval base of the highest importance, a great commercial centre, and 
the most prosperous of British Crown Colonies. Indirectly, the foresight which secured Singapore for the British Empire led also to the extension of British influence throughout the States of the Malay Peninsula, a territory which, under British protection and guidance, has not only far surpassed in rapid development the progress of Raffles' Settlement, but has enormously contributed to the prosperity of both Pinang and Singapore, and proved itself to be, in proportion to its area, one of the richest countries in the world.

In all this, no British party and no British Government can claim to have taken any part, except by grudgingly assenting to what had been done, almost without their knowledge, entirely against their wishes. The man to whom the credit belongs gave his talents and his life to achieve an end which he believed to be necessary to the prestige, the power, and the trade of England in the Far East. He died on 5 July, I826, and was buried in England, but no one knows where to find his grave.

The single consolation vouchsafed to Raffles was the knowledge that Singapore had succeeded beyond his fondest hopes, and that, in the esteem and affection of all classes and nationalities there, he held a place which he never could lose. When he left the island for the last time, in June, 1823, the European and native merchants presented him with an address which contains the following passage :-

"To your unwearied zeal, your vigilance, and your comprehensive views, we owe at once the foundation and maintenance of a Settlement unparalleled for the liberality of the principles on which it has been established; principles the operation of which has converted, in a period short beyond all example, a haunt of pirates into the abode of enterprise, security, and opulence.

"While we acknowledge our own peculiar obligations to you, we reflect at the same time with pride and satisfac- 
tion upon the active and beneficent means by which you have promoted and patronized the diffusion of intellectual and moral improvement, and we anticipate with confidence their happy influence in advancing the cause of humanity and civilization."

Raffles acknowledged this letter, and in the course of his reply, wrote :-

"It has happily been consistent with the policy of Great Britain, and accordant with the principles of the East India Company, that Singapore should be established as a free port; that no sinister, no sordid view, no considerations either of political importance or pecuniary advantage, should interfere with the broad and liberal principles on which the British interests have been established. Monopoly and exclusive privileges, against which public opinion has long raised its voice, are here unknown, and while the Free Port of Singapore is allowed to continue and prosper, as it hitherto has done, the policy and liberality of the East India Company, by whom the Settlement was founded, and under whose protection and control it is still administered, can never be disputed.

"That Singapore will long and always remain a free port, and that no taxes on trade or industry will be established to check its future rise and prosperity, I can have no doubt. I am justified in saying thus much, on the authority of the Supreme Government of India, and on the authority of those who are most likely to have weight in the Councils of our nation at home.

"For the public and peculiar mark of respect which you, Gentlemen, have been desirous of showing me on the occasion of my departure from the Settlement, I beg that you will accept my most sincere thanks. I know the feeling which dictated it, I acknowledge the delicacy with which it has been conveyed, and I prize most highly the gratifying terms to me personally in which it has been expressed." 
Raffles' whole connexion with Singapore extended from February, I8I9, to June, I823, just over four years, and in that time he only visited the island three times; but during those visits, by his personal influence and direction and by the written instructions which he issued to the Resident, he laid the foundations of that liberal and enlightened administration which secured the immediate and lasting success of the Settlement. There is no need to detract from the credit due to others to increase Raffles' fame. His personality and his services were big enough to place him beyond the reach of comparison with men of his own time in eastern administration, but in matters of detail his judgment was sometimes hasty, and he did not like opposition. Singapore has to thank Farquhar and not Raffles for the splendid esplanade, which is one of the most attractive features of the island.

If we have no picturesque record of Raffles' first landing on the shores of Singapore, Abdullah has left us a very pathetic account of his own last hours with his master, and the latter's final departure from the place he had created and of which he was so justly proud. Abdullah writes :-

"On the day after all his things had been put on board the ship, he sent for me and I went to the room where he used to write. He said, ' Take this letter and keep it carefully, with the one I gave you at Malacca. If hereafter any distinguished Englishman comes here, show him the letters and he will befriend you. Moreover, should you get work in the Court, show the letters to whoever is then at the head of affairs in Singapore, and you will receive a higher salary than is usually paid to Malays. Do not grieve, for if I live I will surely return to Singapore; but should I die, then good bye, and I charge you to diligently learn the English language until you know it well. Here is another paper; take it, and when I have gone give it to Mr. Queiros, who will pay you two hundred dollars, which 
I ask you to accept from me. If I ever return, I want to write several books dealing with the countries in this neighbourhood; in them I will mention your name and the great help you have given me in all Malay matters and everything that was within your knowledge, so that white men may know you and trust you.' I could not speak, but I took the papers while the tears streamed down my face without my being conscious of it. That day, to part with Sir Stamford Raffles was to me as the death of my parents. My regret was not because of the benefits I had received, or because of his greatness or attractions; but because of his character and attainments, because every word he said was sincere and reliable, because he never exalted himself or depreciated others. All these things have remained in my heart till now, and though I have seen many distinguished men, many who were clever, who were rich, who were handsome-for character, for the power of winning affection, and for talent and understanding, I have never seen the equal of Sir Stamford Raffles. Though I die and live again, I shall never find his peer. . . . When I had received the two letters, Sir Stamford and his lady went down to the sea accompanied by an immense crowd of people of every nationality. I also went with them, and when they reached the ship they went on board. A moment later preparations were made to heave up the anchor, and Sir Stamford sent for me. I went into his cabin, and saw that he was wiping the tears from his eyes. He said, 'Go home; you must not grieve, for if I live we shall meet again.' Then Lady Raffles came in and gave me twenty-five dollars, saying, 'This is for your children in Malacca.' When I heard that my heart was more than ever fired by the thought of their kindness. I thanked her, and shook them both by the hand; but I could not restrain my tears, so I hurriedly got into my boat and pulled away. When we had gone some distance I looked back and saw Sir Stamford gazing from the port. I saluted him and he 
waved his hand. After some moments the sails filled and the ship moved slowly away."

The great administrator and his Malay protégé were not to meet again, but the eastern did not forget his hero. Raffles' best epitaph is written in Malay; and had he been buried in the country he loved so well, we should know where to find his grave. 


\section{CHAPTER V}

THE STRAITS FROM I825-67-THE ARRANGEMENT MADE TO SETTLE THE CLAIMS OF THE SULTAN AND TËMẼNGGONG IN REGARD TO JOHORE

I

$\mathrm{N}$ January, I819, there were about I 50 inhabitants on the island of Singapore; a few of them were aborigines and the rest people who had accompanied the Dato' Tĕměnggong when he settled there eight years earlier. The Malays lived in boats and miserable huts on the left bank of the Singapore River, and they are supposed to have made a livelihood by piracy; the place was quite uncultivated and covered by jungle, though Raffles, in an exuberance of enthusiasm, wrote that he could trace the fortifications of the ancient citadel, destroyed about six hundred years earlier. The supposed site of this citadel was a small hill (now called Fort Canning) on the left bank of the Singapore River, about a quarter of a mile from the shore. It was entirely overgrown, was called "the Forbidden Hill," and was treated by the Malays with superstitious veneration, as the spot once occupied by the palace of the Raja of Singapore. When cleared of jungle, it was found that there were a number of fruit trees on the hill, the stone foundations of buildings long destroyed, and also some very ancient Malay graves. So far as can now be ascertained, these were, with one exception, the only vestiges of Singapore's former inhabitants. The exception was a curious 
stone found at the mouth of the river, when the right bank was cleared and levelled to prepare it for the site of the present town. A passing reference has already been made to this stone, but, having regard to its unique historic interest, it is well to translate Abdullah's contemporary description of the finding, and subsequent treatment, of this ancient relic. He writes :-

"At that time there was found, at the end of the point, buried in jungle, a smooth, square-sided stone, about six feet long, covered with chiselled characters. No one could read the characters, for they had been exposed to the action of the sea water for God knows how many thousands of years. When the stone was discovered people of every race went in crowds to see it. The Hindus said the writing was Hindi, but they could not read it. The Chinese said it was Chinese. I went with Sir Stamford Raffles and the Reverend Mr. Thompson and others, and to me it seemed that the letters resembled Arabic letters, but I could not decipher them, owing to the ages during which the stone had been subject to the rise and fall of the tides. Numbers of clever people came to read the inscription; some brought soft dough and took an impression, while others brought black ink and smeared it over the stone in order to make the writing plain. Every one exhausted his ingenuity in attempts to ascertain the nature of the characters and the language, but all without success. So the stone remained where it lay, with the tide washing it every day. Then Sir Stamford Raffles decided that the writing was in the Hindi character, because the Hindus were the first people to come to these parts, to Java, Bali, and Siam, whose people are all descended from Hindus. But not a man in Singapore could say what was the meaning of the words cut on that stone; only God knows. And the stone remained there till Mr. Bonham became ${ }^{1}$ Governor of Singapore, 
Pinang, and Malacca. At that time Mr. Colman was the Government Engineer at Singapore, and he, sad to tell, broke the stone. In my opinion it was a very improper thing to do, but perhaps it was due to his stupidity and ignorance, and because he could not understand the writing that he destroyed the stone. It never occurred to him that there might be others more clever than himself who could unravel the secret; for I have heard that there are those, in England, who are able to read such a riddle as this with ease, whatever the language, whoever the people who wrote it. As the Malays say: 'What you can't mend, don't destroy.'"

It almost passes belief that the only existing clue to the very early history of Singapore should have been ruthlessly and quite needlessly destroyed, but so it is. The stone was deliberately blown to pieces; a few of the fragments were collected by some of the more intelligent Europeans and placed in Government buildings, from whence they were eventually sent to the Asiatic Society's Museum in Calcutta. Lieutenant Begbie, writing in 1834 , gives it as his opinion, that this stone is the one referred to in a story in the Malay Annals describing a contest of strength between a Singapura Samson, named Bâdang, and a rival from the Coromandel coast. Bâdang won the contest, and the annalist says that when Bâdang died, and was buried at the mouth of the Singapura River, the Coromandel King sent two stones to mark his grave. Lieutenant Begbie suggested that this was one of them.

It appears, however, that besides the fragments, a rubbing of the unbroken stone had reached Calcutta. The wise men there gave up the attempt to decipher the inscription, but offered a pious opinion that it was written in Javanese, before the conversion of the Malays to Muhammadanism.

The conclusion is not very satisfying, but as there seems to be no means of raising the veil and getting at the 
secret, we come back to the fact that Singapore, when Raffles fixed upon it as the place for his new station, was a jungle-covered island with 150 inhabitants whose business was, probably, piracy. It is almost impossible at this date to realize the bondage in which the Straits of Malacca, and especially the Johore Strait, were held by pirates, not only in 1820 , but even in 1840 and later. Abdullah says that the skulls of hundreds of victims of piracy were, in 1819, floating in the waters of Singapore harbour, and were collected and disposed of by the orders of Colonel Farquhar. The accounts of piracies and the measures taken, in the next twenty years, to put down the practice, are one long record of murder and robbery, the capture and sale of boys and girls, women and children, with severe measures of repression. The pirates often mistook the vessels of war for traders, and when too late they discovered their mistake, they seem to have fought with a desperate courage which almost invariably resulted in their annihilation. When Raffles left the East, the question of piracy was one which he pressed upon the most earnest attention of the Resident in Singapore, and nothing but a perusal of the official records of the time could convey any real idea of the extent of the evil, or the years that it took to eradicate it.

Meanwhile, in spite of this great difficulty, Singapore grew and prospered; while the older settlements, Malacca and Pinang, the latter severely handicapped against its free-trade rival, were a serious charge on the resources of the East India Company. In 1825 the three settlements became a Presidency of India, and in 1827 Lord William Bentinck, the then Governor-General, visited them in order to look into matters. He declared that he could not see what Pinang was like for the number of cocked hats which shut out the view, so he reduced the establishments, abolished the duties, and reorganized the Government. From 1829 the Straits ceased to be a Presidency 
and were placed under the Government of Bengal, but in I85 I they passed to the control of the Supreme Government of India, and so remained until they became a colony in 1867 .

When Raffles left Singapore, in 1824 , the population of the settlement was stated to be about 10,000, and the tonnage of the shipping 75,000. Newbold, writing in 1839, gives the following figures as the revenue and expenditure of the three Settlements in the years $1835-6$, but the expenditure does not include the cost of either the military or the convict establishments, so the annual loss must have been very considerable.

$$
\begin{aligned}
& \text { Revenue in } \\
& \text { Sicca Rupees. }{ }^{1} \text { Expenditure. Population. } \\
& \begin{array}{lllllll}
\text { Malacca } & \dot{P}_{\text {r }} & 62,757 & \ldots & 160,057 & \ldots & 37,706
\end{array} \\
& \text { Pinang and Prov- } \\
& \begin{array}{lllllll}
\text { ince Wellesley . } & 178,930 & \ldots & 253,328 & \ldots & 86,009
\end{array} \\
& \begin{array}{lllllll}
\text { Singapore } . ~ & \cdot & 274,178 & \ldots & 222,333 & \ldots & 29,984
\end{array}
\end{aligned}
$$

The tonnage of the Singapore shipping for the same year was returned as 200,000 tons. In eleven years, therefore, Singapore had trebled its population and almost trebled its trade, while in proportion to its population it was earning a far larger revenue than either of the other Settlements. The main source of revenue was an excise duty on the sale of opium and spirits, and in order to save the Government the trouble and expense of collecting and protecting this revenue, it was farmed out for a term of years to the highest bidders, so that the preparation of the raw opium for sale by retail dealers, the issue of licences to sell, and the whole trade in opium within the Straits Presidency, became a monopoly, held almost invariably by Chinese. In the earliest days of Singapore there was

${ }^{1}$ It is impossible to avoid giving values in rupees and dollars, though, when it could be done with certainty, the sterling equivalent is also stated. The sterling value of both rupees and dollars has so constantly varied that, in many cases, such for instance as the cost of railways spread over many years and paid for in dollars, the amount cannot be rendered into sterling with accuracy. 


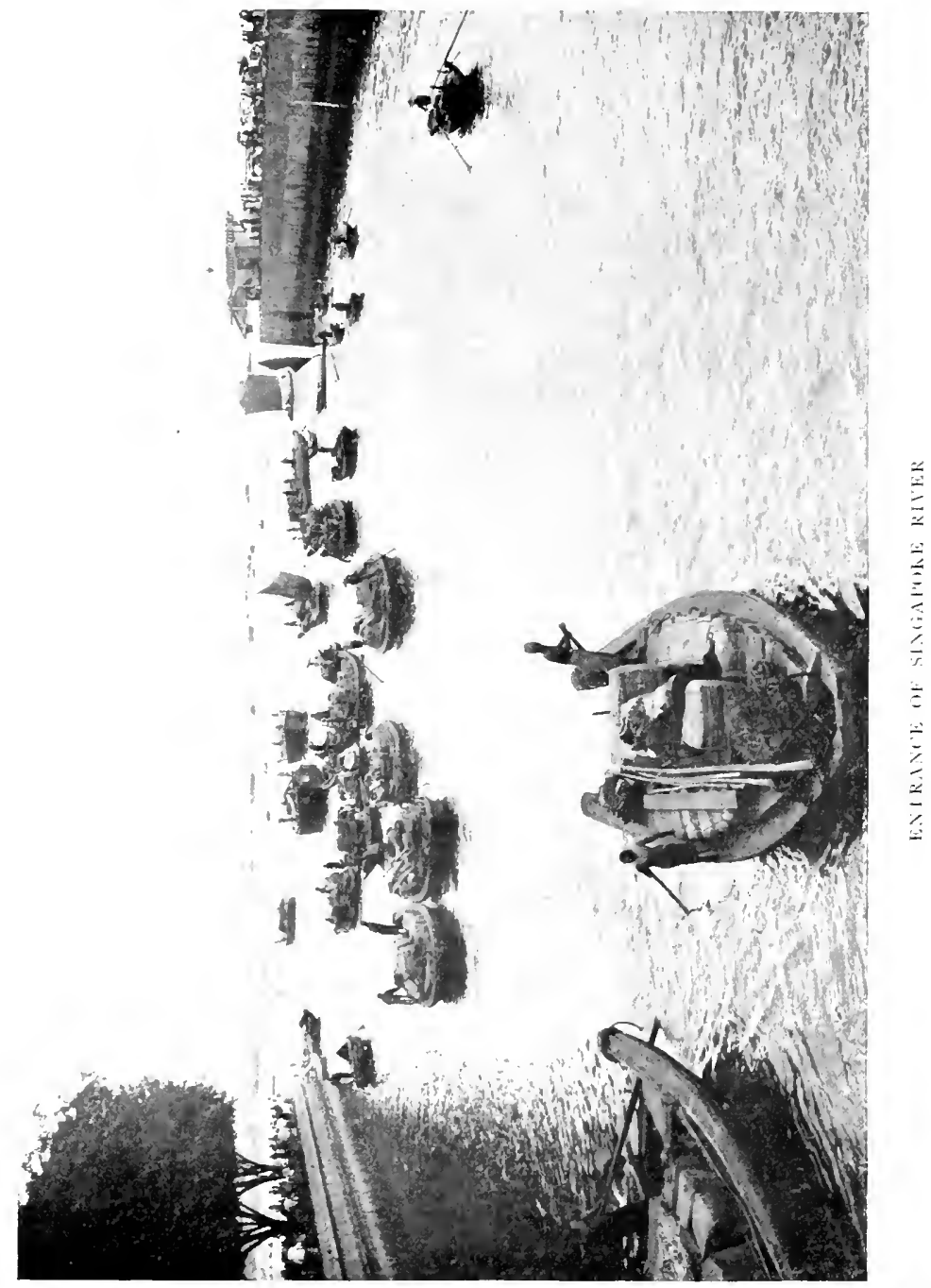



also a farm of the right to maintain public gambling establishments, but Sir Stamford Raffles set his face against this method of raising revenue, and he was supported by the majority of the European mercantile community. The Company was not so anxious to suppress a practice which had long been countenanced in Pinang, but Raffles' advice was adopted in 1829 . Since that time, the question has been repeatedly argued and the weight of dispassionate opinion held that Sir Stamford Raffles was, in this instance, mistaken, and that the reasons he put forward in support of his views were neither sound nor logical. The fact remains that gambling in the Straits was prohibited, and has remained so, though the practice has been recognized and legalized in most of the neighbouring colonies of other nations, and in all independent States.

By the year 1864 the revenue of the Settlements had risen to $£ \mathrm{I} 92,000$, and the civil expenditure to $£ \mathrm{II} 4,932$, with a military charge of $£ 81,073$ in addition. Twothirds of the revenue were derived from the excise farms, $£ 26,000$ from stamp duties, and only $£ 6705$ from lands and forests. The Governor's salary was $£ 4200$ (though the Governor of Pinang, many years earlier, had been in receipt of $£ 9000$ a year), and the principal item of expenditure was the cost of constructing certain land defences which, at the time of their building, were recognized to be useless, and were of necessity abandoned.

During the period now so briefly reviewed, from 1825 to 1867 , nothing of any importance occurred in Malacca beyond a difference with a very small border State called Naning. This quarrel resulted in the dispatch of two small military expeditions, which took many months to accomplish, at a cost of a million rupees, or $£ \mathrm{I} 00,000$, what should have been done in a week. The business began in August, I 831, and was completed in May, I 832, the troops taking ten weeks to cover the last twelve miles 
of a march, the goal of which was only twenty-two miles from the town of Malacca.

In Pinang there was no occurrence of any importance ; but just as the founding of this Settlement had taken much of the trade from Malacca, so, with the opening of a free port at Singapore under the enlightened direction of Raffles, Pinang lost much of her trade and prosperity. Indeed, it was freely and constantly stated in the fifties not only that Pinang was a financial failure, but that it was ridiculous to suppose that the Settlement could ever be self-supporting. Even in the seventies it was still held that Singapore surpluses paid for the deficiencies of Pinang and Malacca, though the people of Pinang declined to subscribe to that theory, the difference of opinion resting mainly on the apportionment of military and civil charges paid by the colony as a whole.

From the smallness of the land revenue, it will be understood that no great progress had been made in the cultivation of the soil. This was mainly owing to the extraordinarily illiberal land policy of the East India Company and its officers. In Singapore, however, with the poorest soil, the greatest efforts had been made and the largest success achieved. That was only for a very short time. Partly owing to the fact that three successive crops practically exhausted the land, and partly because of a blight which destroyed the spice trees, cultivation on anything like an extensive scale came to a sudden end, and the Chinese, who had been engaged in this industry, passed across the narrow Strait which divided the island from the mainland of Johore. When Singapore was occupied, in 1819, it had no permanent inhabitants, and there was not an acre of cultivation on the island. It was the same in Johore, and that place obtained its first cultivators from Singapore, and grew to prosperity simply by reason of its proximity to the English Settlement.

The reader will remember that Raffles made his first 
treaty with the Tĕmenggong of Johore (a high officer of the Sultan), who, for his own reasons, happened to be on the island when Raffles arrived. The treaty was signed by the Tĕmĕnggong, on his own account and on behalf of the Sultan of Johore, his master. Raffles sent to Rhio for the rightful claimant to this title, acknowledged him as Sultan, and made a new treaty with both Sultan and Tĕmĕnggong, agreeing to pay certain allowances to each of them. In the course of time both these Malays died, and while the Tĕmenggong's son immediately succeeded his father and was recognized by the Indian Government, that authority declined to recognize as Sultan of Johore the son of the man whom their own officer had, with their full approval, invested with the title. It is not a nice story, and it has never been told, yet it is necessary for the purposes of this book to give it. The East India Company is dead, but it is impossible to observe, in regard to that body, the kindly injunction, de mortuis nil nisi bonum. We have seen how that Company behaved to the Sultan of Kĕdah, to Mr. Light, and to Sir Stamford Raffles; their treatment of Tunku Ali was no better, though in his case there were local influences which helped to his destruction. The tale, if it were all told, is a long one; so I will spare the reader the proof of every statement, the quotation of all the authorities, and give the facts as shortly as possible, merely remarking that they are the result of weeks of incessant work, searching for and examining long-forgotten documents in the archives of Government offices.

Colonel Butterworth was Governor of the Straits from I 843 to I 855 , and during the latter part of his rule considerable friction had arisen between the Tĕmĕnggong Ibrahim and Tunku Ali, the son and heir of Sultan Husein of Johore. Colonel Butterworth went on leave to Australia in November, 185 I, returning in November, 1853, and during his absence Mr. Blundell, the Resident Councillor of Pinang, an officer with great local experience, officiated for him. 
It is necessary to remember that the Sultan Husein of Johore, and the Dato' Tĕmĕnggong, were living in Singapore as pensioners of the East India Company, because, as Johore was quite uninhabited, they had only a few personal followers, no subjects, and no revenues.

Dato'Tĕmĕnggong Abdulrahman died in 1825 , and was immediately succeeded by his second son Ibrahim, though the office of Tĕmĕnggong in a Malay State is not necessarily an hereditary office. Sultan Husein died in I835, and, though his eldest son, Tunku Ali, repeatedly asked that the Government of Bengal should recognize him as Sultan of Johore, the request was ignored or refused ; but a proclamation was issued in 1840 recognizing him as his father's successor "in every respect." That concession was evidently counted as of no value, and though Tunku Ali's case seems to have been urged on the Government, they replied with a curt negative on the ground that there was no plea of expediency. The plea was one of justice, and involved nothing but the title to which Tunku Ali had an undisputed claim. When, however, the spice plantations of Singapore failed, between I 835 and I 840 , and Chinese began to settle in Johore, then, for the first time, that State developed a present and prospective value as a revenue-producing property, and it became a matter of considerable moment to whom the revenue should be paid. On 2 I October, I 846, Governor Butterworth wrote as follows to the Under-Secretary to the Government of Bengal :-

"I cannot ascertain that any revenue is or ever has been derived from the territory of Johore, either by the late or present Sultan and Tĕmĕnggong, beyond a trifling duty on timber-which is irregularly collected by the latter chief-but the late emigration of the Chinese to the opposite coast has induced the opium farmer to enter into an agreement with the Tĕmĕnggong to extend the farm to that Settlement on payment to him of $\$ 300$ per mensem, as reported in my letter under date the 14 September last, 
No. I 38 , which I think should be equally divided between the Tĕmĕnggong and Sultan, and I will, if the Honourable the Deputy-Governor of Bengal approve of it, endeavour to carry this arrangement into effect.

"I have little doubt that I could bring the Temernggong and the Bendahara of Pahang to accede to the young Sultan's formal installation, but the ceremony consequent on such an event would cost a considerable sum of money for which Tunku Ali would look to the Government, as also for the means of supporting the dignity of his new position which neither his outward bearing nor his intellectual capacity would enable him to do against the powerful influence of the Tĕmĕnggong of Johore."

It is noticeable here that the Governor styles Tunku Ali "the Sultan", that he says the small revenue of Johore had hitherto been irregularly collected by the Tĕmĕnggong, that the Governor thought the $£ 800$ a year offered by the farmer should be equally divided between the Sultan and the Tĕmĕnggong, and that the latter was a person with "powerful influence." This influence could only have been derived from Europeans.

At the same time, precisely 25 August, I846, the Resident Councillor of Singapore wrote to the Governor :-

"The Tĕmĕnggong appears to exercise exclusive and supreme control over the dominions of Johore. This arises in consequence of Tunku Ali not having been regularly installed and recognized as Sultan."

There was no plea of "expediency," nothing for the Company to gain, by acknowledging Tunku Ali as Sultan; quite the contrary ; for it was pointed out that his pension or allowance amounted to $\$$ II 5 a month, about $£ 300$ a year, and that he would not be able to support his title, his family, and his followers on that income. Therefore the Company turned a deaf ear to the representations of its officers. 
In $1852 \mathrm{Mr}$. E. A. Blundell was officiating as Governor, and he appears to have gone very carefully into this question. On 20 July he wrote as follows to the Government of India :-

"I deem it my duty to request that you will lay before the most noble the Governor-General of India in Council the subject of our present relations with the Chiefs of the country of Johore, of which the island of Singapore was at one time a dependency. My object in so doing is to endeavour to obtain a final settlement of various conflicting rights and claims, regarding which the present disputes are causing violent family quarrels, and seem to me to tend towards disruption and bloodshed in the State.

" 2 . The first question calling for decision is the claim of Tunku Ali, son of the late Sultan of Johore, to be installed as Sultan of that country. The two Princes (the Sultan and Termĕnggong of Johore) who signed the Treaty of 2 August, I824, with Mr. J. Crawford, are both dead. The eldest son of the Sultan was a minor at the time of the death of his father, while the eldest ${ }^{1}$ son of the Tĕmĕnggong was, soon after his father's death, duly installed in the office of Tĕmĕnggong. In I 846 Tunku Ali, eldest surviving son of the Sultan, applied to be acknowledged and installed as Sultan, and his application was transmitted to Government by Colonel Butterworth, with a letter dated 2 I October, I 846 , to which the reply of 23 January, 1847, was to the effect that unless some political advantage could be shown to accrue from the measure the Honourable the President in Council declined to adopt it.

"3. I am not prepared to state that any political advantage would accrue at the present time from acknowledging Tunku Ali as the Sultan of Johore, but I certainly think it impolitic to allow such an apparently clear and undisputed claim to remain any longer in abeyance.

1 It was the second son. 
"The Malayan laws of hereditary succession are burened with many restrictions and conflicting rights and interests of other parties, which render it in some measure elective. Certain high officers of the State must concur in acknowledging the claim of a successor, who of course finds it necessary to bind them to his interests by handsome presents and promises for the future. Until the sanction and approval of these State officers be obtained, no claim to the 'Musnud' is, in theory, held valid, and the natural consequence is that, in all Malayan States, when the supreme authority is weakened, the hereditary succession is attended with disputes and bloodshed. In the case of Johore, the succession to the Sultanship requires the sanction of the Termĕnggong and the Bĕndahâra. Of these two great officers, the first, the Termenggong, is a pensioner, and is dependent on the British Government, being the son of him who signed the Treaty of I 824 with Mr. Crawford, and receiving an allowance of $\$ 350$ a month for himself and his father's family. It would appear that the Governorship of Johore, under the Sultan, is, or was, an hereditary appanage of the Tĕmĕnggong, and in virtue of this, the present man, while residing wholly at Singapore, has administered the Government of Johore and possessed himself of the entire revenue of the country, preventing (and in some instances forcibly) the young Sultan from exercising any of the rights of sovereignty. ...

"5. I cannot deny that it seems better for our interests that the rule over the country of Johore should remain, as at present, wholly in the hands of the Termernggong. Owing to the notice extended towards him by the Government of the Straits, and by the Mercantile community of Singapore, he has become comparatively civilized, and is undoubtedly superior to the young Sultan in the capacity to govern the country of Johore in subservience to British interests, but I am bound to state it as my 
opinion that if the same degree of notice had been extended towards Tunku Ali, both by the Government and the community of Singapore, that is, had he in his youth been taken by the hand, his vices discouraged and his good qualities fostered, he would have proved himself as good a ruler, and as valuable an ally, as the Tĕmĕnggong. As it is, I agree with the resident Councillor at Singapore, in thinking that much confusion and trouble may ensue from recognizing him as the Sultan, but still I am impressed with the injustice of disregarding the claims of the son of the Prince from whom we obtained the island of Singapore, simply because it is less troublesome, and perhaps more advantageous to us, that the rule should continue in the hands of a subordinate officer. . . . I doubt not that, at the instance of the British Government, the two great officers will do immediately what is required of them without insisting on the receipt of the customary presents. . . .

"7. . . . It consists of a letter addressed to me by Tunku Ali which was transmitted to the Resident Councillor at Singapore, whose reply embodies the objections that may be urged against the recognition of Tunku Ali as Sultan. These objections seem founded solely on expediency, but I think myself if the principle of Justice towards all parties be recognized and followed, the evils that may result from the change of policy will soon be overcome.

"8. . . . But if the Governor-General of India in Council should be pleased to think that, in justice towards this young Prince, we are bound to see him so installed, the expression of such an opinion, on the part of the Supreme Government of India, will remove most of the difficulties.

"9. . . . The present Tĕmĕnggong who administers the affairs of the country (Johore) and enjoys the whole revenue, lives at Singapore as a British subject. . . ." 
Mr. Blundell's appeal to the Government of India's sense of justice met with an unfavourable reply, but he returned to the charge with a letter dated I4 January, 1853 , and the following are the most important paragraphs :-

"I have communicated to Tunku Ali, the son of the late Sultan of Johore, the decision of the Government of India not to interfere in installing him in his father's place as Sultan. ...

"Granting that the Sultan brought forward to sign the Treaty of 1824 was a nullity, and that the whole Government of the country rested with the Těmĕnggong, still we recognized a Sultan of Johore and paid to him considerably more money than to the Termenggong. The consequence of this is that the son of the Sultan claims a higher position and superior power to the son of the Tĕmenggong. This claim is recognized by many of the natives of the country; there is natural veneration for the title of Sultan, and among the European community of Singapore, where the rights and claims of both parties are much discussed, I am inclined to think that the only point in favour of the Tĕměnggong is that he has been longer known to the community, has become familiar with many, and has allowed his sons to acquire a taste for English habits, manners, and dress. The Tĕmĕnggong, who for fifteen years since his installation has ruled the country of Johore and enjoyed all its revenues, lives in Singapore as a British subject. These revenues arise chiefly from the proximity of his country to Singapore and the consesequent extension to it of our peculiar Excise laws. . . . But it appears to me unjust that one family should enjoy all the pecuniary advantages of this safe and easy mode of Government to the exclusion of the family of the Sultan. ... I have therefore recommended to the Tĕmĕnggong that, provided Tunku Ali will engage not to interfere at any time with the Government of the country, he 
should agree to clear the way for his installation as Sultan, and make over to him half the revenue of the country, calculating that half at $\$ 300$ per mensem for three years, at the expiration of which a new calculation to be made.

"To this arrangement both parties have agreed. I have now the honour to solicit a confirmation of it on the part of the Government of India."

We may not be able to follow Mr. Blundell's reasoning in the course he recommended to Tunku Ali, and that is why we cannot but wonder that he could not find some plea of expediency with which to satisfy the Government of India when he realized that it was useless to harp on the string of justice.

There is a striking similarity between this case and that of the Sultan of Kĕdah.

To secure Pinang the Government's Agent might promise almost anything, but when the end was gained the Company saw no need to redeem the promises. To gain Singapore the Agent was authorized to recognize a Sultan of Johore, who alone could give the Company a good title to the land. As no one had imagination enough to suggest how there might be a "political advantage "in recognizing the succession of their own Sultan's son, they declined to adopt the proposal as a mere matter of justice. If the son suffered, and the Termernggong gained by their lop-sided view of the duties of a paramount Power, it was not their concern, for they stated quite openly-to their officers-that they only interfered when they were satisfied that some advantage would result. But it is well to let the Government of India speak for itself. In a letter to Governor Blundell, dated 4 March, I853, the Secretary to that Government writes:-

"In reply, I am directed to inform you that the Government of India has no concern with the relations between the Sultan and the Tĕmĕnggong. When it wished to con- 
clude a treaty for the cession of Singapore, in I824, it recognized the Sultan and the Temmenggong as joint rulers in Johore. It styled them 'their Highnesses the Sultan and Tĕmĕnggong of Johore.' But neither then nor at any subsequent period did the Government of India seek to define what share of authority belonged to either, or what proportion of revenue should be enjoyed by either. ... If the arbitration in question should be proposed, and the Tĕmĕnggong should be willing to purchase entire sovereignty by a sacrifice of revenue in favour of the Sultan, the Governor-General in Council conceives that the measure would be a beneficial one to all parties."

Of course the Government of India "did not seek to define what proportion of revenue should be enjoyed by either" because, in 1824 , there was no revenue to enjoy. But if the Government of India regarded the Sultan and Tĕmĕnggong as "joint rulers in Johore"-without making any proper inquiries into their relative positions-it was surely a misuse of language, to talk of the Tĕmĕnggong purchasing entire sovereignty by a sacrifice of revenue in favour of the Sultan, when Mr. Blundell had written that the Sultan and Temernggong were willing to divide the revenues, on an estimate of receipts for three years, at the expiration of which a new calculation would be made. That arrangement, already agreed to by the parties, and recommended by Governor Blundell, was the one approved in this letter from the Government of India.

It is very important to remember this fact, because, before Mr. Blundell acted on the sanction conveyed to his proposal, Colonel Butterworth returned from leave and took over the Government. It is probable that there would have been delay, for Mr. Blundell passed a good deal of his time at Pinang, and as he was only officiating for the substantive holder of the Governorship, he may have decided that he ought to leave this question to Colonel Butterworth, who would so soon be back at his post. 
The letter from the Government of India was dated 4 March, 1853 , but, for reasons given, it was not till 22 December, 1854, more than a year after his return to Singapore, that Colonel Butterworth dealt with it, in the following dispatch, written at Pinang :-

"2. The Sultan and Tĕmĕnggong sought my intervention soon after I came back from the Colonies, but the former had become entangled with an European merchant at Singapore, the gentleman adverted to by Mr. Church as holding possession of the Royal Seal, and it was not till Tunku Ali had freed himself that I consented to arbitrate between the two Chieftains, when I proposed the terms laid down in the concluding paragraph of your letter, under date 4 March, I853, viz. that the Sultan should resign the whole territory of Johore to the Termenggong, on receiving the sum of five thousand dollars on the ratification of the agreement, and five hundred dollars per mensem in perpetuity.

"3. The Sultan, under the influence of his friends, declined the terms proposed by me, and I left Singapore for this station; but the case was very shortly opened by him, through the Resident Councillor, with his expressed determination to abide by my decision, at the same time, however, soliciting permission to keep possession of the Kesang-Muar, a small tract of country between the Kesang and Muar rivers, the former being the southern boundary of the Malacca territory, as shown in the accompanying outline sketch. ${ }^{1}$

"The Resident Councillor earnestly urges this concession to Tunku Ali, if I may so designate the desire of the Sultan to retain the above portion of Johore, in which I am led to believe some of his ancestors are buried. Then the Tĕmĕnggong objected, evidently, however, without any intention of finally rejecting the proposition, for on

1 The sketch map was taken from Moore's Eastern Archipelag'o. 
receiving my reply, forwarded under cover to the Resident Councillor, to the effect that I had no wish to coerce him in any way, he immediately sent in his concurrence to the heads of the treaty now submitted."

In a question of such importance, which has had such far-reaching effects, not only on the principals and their descendants, but throughout the Malay Peninsula, the less the historian indulges in speculation the better. The documents available are, however, sufficient evidence on which to form a dispassionate judgment. Governor Blundell made a certain recommendation to the Government of India, and he stated that both Sultan and Tĕmĕnggong accepted his proposal. It is probable that Mr. Blundell, when in Singapore, had personally conducted the negotiations. The Government of India approved, adding that it was no concern of theirs if the Tĕmĕnggong chose to sacrifice revenue in order to gain complete sovereignty. Then Governor Butterworth returned, and being told that Tunku Ali was "entangled with an European merchant at Singapore," declined to arbitrate, in a matter which was already settled, and went to Pinang. It is certain that the further negotiations were carried on by the Resident Councillor of Singapore, Mr. T. Church, and he succeeded in putting an entirely different complexion on the terms of agreement; so that we have Governor Butterworth addressing the Government of India, purporting to quote from that Government's dispatch of $4 \mathrm{March}$, 1853 , terms which were never written, or ever imagined, and suggesting that, as a favour, Tunku Ali, when installed as Sultan of Johore, should be allowed to retain a small district called Kesang-Muar, and receive $\$ 500$ a month in perpetuity. That is to say, the Government of India having approved Governor Blundell's recommendation of $\$ 300$ a month, for three years, and then a new calculation of the value of the Johore revenues, Governor Butterworth, acting on the advice of $\mathrm{Mr}$. Church, 
settles the matter by giving $\$ 5000$ down, $\$ 500$ a month in perpetuity, and allowing the Sultan to retain the district of Muar, on the confines of Malacca, not because it would yield an income, but because it contained the graves of the Sultan's ancestors!

A writer may hesitate to characterize these proceedings in plain language, but the reader will have no difficulty in arriving at a correct conclusion. Mr. Church's influence in the final arrangement may be gathered from the following extracts from two letters written by him to the secretary to the Governor. The first is dated 28 April, 1854:-

"4. Translations of the terms proposed by Tunku Ali and the Tĕmĕnggong respectively, I beg to enclose for the information of His Honour the Governor, under whose sanction I have acted.

" 5. For Tunku Ali to accept without modifications the conditions propounded by the Tĕmĕnggong would be a voluntary relinquishment, for himself and heirs for ever, of all power and influence as a chief, a position not likely to be adopted in any part of the world.

"7. The relative position of the Sultan and Tĕmĕnggong of Johore will be found accurately described in $\mathrm{Mr}$. Crawford's able letter dated the 3 rd August, i824, to the address of the Government of India. The words are: 'I have viewed the Sultan as possessing the right of paramount dominion, and the Tĕmĕnggong as not only virtually exercising the power of government, but being, like other Asiatic sovereigns, de facto, the real proprietor of the soil.' . . . and (he) appropriates the entire revenues to his own use; it is questionable whether the latter procedure is consistent with Malay usage with reference to the heir and other members of the Sultan's family." 
As regards the quotation in this letter from $\mathrm{Mr}$. Crawford, formerly Resident of Singapore, I venture to disagree with his definition. Mr. Crawford must have known that the Tĕmĕnggong was not a sovereign, for had he been so, there was no need to send to Rhio for Tunku Husein, and recognize him as Sultan in order that the Company might have a sound title for their occupation of the island. Indeed, it is difficult, without a smile, to think of the Tĕmĕnggong, with his handful of followers, eking out a precarious existence in the creeks of Singapore as "an Asiatic sovereign, virtually exercising the power of government." It is, however, a question which Mr. Crawford has himself decided, and though the statement in his letter of 3 August, 1824, has often been quoted as the last word of authority, no one seems to have noticed that in his Account of Siam, published in 1830, he writes: "It was with this individual and the inferior chief already named, that a treaty for the cession of the island was concluded in August, 1824." The individual was Sultan Husein, and the inferior chief the Tĕmĕnggong Abdulrahman.

Enclosed in the Resident's letter of 28 April, 1854, were the new proposals of Tunku Ali and the Tĕmĕnggong Ibrahim, put forward in the course of their later negotiations with Mr. Church. Tunku Ali's proposals were these :-

I. "Inche Wan Ibrahim [that is, the Termenggong] must, in the first instance, recognize us and also assist in the installation of me as Sultan, together with the other chiefs, whenever we may be pleased to require it.

2. "Inche Wan Ibrahim will govern a portion of Johore Empire, of which the limits will be hereafter defined, and to hold such government as a Minister under the authority of the Sultan of Johore.

3. "The revenues of the province placed under the authority of Inche Wan Ibrahim are to be divided in such 
a manner as may be considered equitable and proper, a deduction being made for the expenses of collection and other charges.

4. "The seal and chap of Inche Wan Ibrahim to be hereafter of the customary form and size which has been adopted by those of his rank and prescribed by Malay usage.

5. "When the terms are agreed to, Inche Wan Ibrahim is to pay to us the sum of $\$ 10,000$.

6. "The treaty of the I 9 th November, $1824,{ }^{1}$ is in no way to be infringed by the present arrangement.

"Written at Kampong Glam on Saturday, 22 April, I854."

The terms submitted by the Tĕmĕnggong on 3 April, I 854, were as follows :-

I. "Dato Tĕmĕnggong Sri Maharaja, at present residing at Teluk Blanga, Singapore, with his heirs and successors, to be recognized as the rightful rulers of Johore and Dependencies for ever, and that Tunku Ali, his heirs, successors, and relations, are not to interfere in the government of the country.

2. "Tunku Ali, his heirs and successors to be recognized as Sultan of Johore under an agreement to be drawn up, the Sultan and his relations engaging at the same time never to rule at Johore, or reside there, without previously informing the Tĕměnggong of such intention.

3. "A stipulated amount of the revenues of Johore to be fixed in perpetuity to be paid by the Teměnggong to Tunku Ali in accordance with an agreement drawn up last year."

The agreement drawn up last year was no doubt the one referred to by Governor Blundell as having been accepted by both parties.

\footnotetext{
${ }^{1}$ A mistake for 3 August, 1824.
} 
On I6 November, I854, Mr. Church wrote to the Governor's secretary :-

“. . . The request made by Tunku Ali to retain Muar (to be bounded by the Kesang and Muar rivers) is by no means unreasonable; indeed, for the Temengggong to refuse to concede the point would have the appearance of avarice and a disposition to take advantage of and add to the humiliation of Tunku Ali and his brothers. . . . The Tĕmĕnggong has doubtless much reluctance there should be a semblance of a compliance with the demands of Tunku Ali."

Apparently there was not to be any compliance with the demands of Tunku Ali in regard to the only points which mattered, the government and the apportionment of the revenues of Johore. As to the reluctance of the Tĕměnggong, it may be gathered from this letter to Governor Butterworth, dated I 3 December, 1854.

"We have to acquaint our friend, with regard to Tunku Ali's request made to our friend. The left side of Sungei Muar, going up, will be Tunku Ali's according to the arrangement between our son Abubakar and Mr. Church, the Resident Councillor, with this arrangement we are much pleased. . . . Moreover we wish this matter to be settled under the auspices of our friend and to be finally terminated with our friend. . . We have every hope for the settlement of this question."

About the same date, on I 8 December, I 854, Tunku Ali wrote to Mr. Church :-

"We make known to our friend that, respecting our affairs with the Tĕmĕnggong, we have desired our brother Tunku Jaffar to confer with our friend. Whatever he has mentioned to our friend and the terms and conditions arranged between him and our friend we will now accept. If our friend's further assistance cannot be obtained in 
respect to our former letter, we have no other resource but to follow. Moreover, we have hitherto written with our seal duly affixed; in this instance there is no seal. This matters not, for our seal is displeased. We make this explanation that our friend may not take it amiss."

The "reluctance" seems to have been on the part of Tunku Ali, who gained the empty title of Sultan of Johore, which was his by right, and lost all material advantage except $£$ IOOO down, an allowance of $\$ 500$ a month, and the graves of his ancestors.

Governor Butterworth's letter to the Government of India, dated 22 December, I 854, was written directly after the above papers reached him in Pinang, and he reported later that the Treaty, between the Sultan and the Termenggong was concluded on Io March, I855. By that Treaty Tunku Ali, then, for the first time, twenty years after his father's death, was publicly acknowledged to be Sultan of Johore, on condition that he renounced all claim to the Government and revenues of that State. The Terměnggong came into full possession of these advantages, and he undertook to pay to Sultan Ali, and his heirs and successors, $\$ 500$ a month for ever, and to allow him to retain the district of Muar. It is said that, when the moment came for Sultan Ali to affix his seal to the Treaty, the seal_or chăp, as Malays call it-was so "displeased," that it was only put upon the document under considerable pressure.

To avoid a further reference to an unpleasant subject, it may be mentioned here that the annual revenues of Johore have amounted to over a million dollars for some years, and they are now, probably, about $\$ 1,200,000$, or, say, $£$ I 40,000 . Sultan Ali is dead, and his son would still be in receipt of $\$ 500$ a month from Johore (originally about $£$ I 200 a year), but the district of Muar has also passed away from him and his family to the Tĕmĕnggong's successors. When that further transfer took place, about twenty 
years ago, the allowance was, by the efforts of Governor Sir William Robinson, raised to $\$ 1250$ a month, divided amongst the late Sultan's family. Lastly, it must be noted that, though the second condition in the terms submitted by the Tĕměnggong on 3 April, I 854, was "Tunku Ali, his heirs and successors to be recognized as Sultan of Johore," the son and heir of Sultan Ali was never more than Tunku Alam, while the son and heir of the Tĕmĕnggong became the "Sultan of the State and Territory of Johore," and that is the title held by his grandson, the present Sultan. The grandson of Sultan Ali is to-day Tunku Mahmud. If Sultan Ali sold his birthright, in I 855 , to secure the recognition of his title by the Government of India, he made a poor bargain. The Government of India loftily disclaimed any concern with the relations between the Sultan and the Tĕmĕnggong; however indifferent that plea, it is one to which neither the local nor the British Government can lay any claim in their subsequent proceedings.

In the year 1863 there was formed, in Singapore, the nucleus of a company, with a capital of only about $£ 30,000$, to construct wharves, docks, and warehouses on the shore of what was then known as New Harbour, but has since been very properly renamed Keppel Harbour, in honour of the late Admiral Sir Harry Keppel, G.C.B., who first sailed a ship through it. This small company, whose capital had to be considerably increased in 1865 , built the famous Tanjong Pagar Docks, which are so much a part of the modern existence of Singapore-as a great coaling and refitting station and port of call for all vessels engaged in the Far Eastern trade-that the local Government decided, last year, to expropriate the proprietors, take over all the works and business, and spend a very large sum of money in providing further and better accommodation of all kinds. Apart from other considerations, the development of railway enterprise in the Malay States 
made this step very advisable; for it is highly probable that in the near future the interests of the dock, as a private concern, would not be identical with the interests of the railways, which are Government property. It is clearly of great moment that both the docks and the railways should be worked in the best interests of the colony and Malay States, rather than for private ends.

In 1857 the European population of the Straits began to agitate for severance from Indian control, and the grant of a separate and independent Government under the Crown. They petitioned the Houses of Parliament in a long statement of grievances which may be briefly summarized thus: That the Straits were too far from India for that Government to understand, and rapidly deal with, their wants; that since the Indian Government had lost their monopoly of trade with China, they took very little interest in the Straits, and refused to consider the reasonable wishes of those most nearly concerned; that the Straits were made a dumping-ground for Indian convicts of the worst type, and were over-burdened by troops, with an outrageous proportion of field officers, while the dependency was made to pay for both troops and convicts; that as there was no Council of any kind, the community was not represented; and, finally, that the Indian Government and its officers had altogether neglected the cultivation of good relations with the neighbouring Malay States, so that while the Dutch, the French, and the Spaniards had seized almost every seizable place in the neighbourhood, British interests had suffered and British influence had waned. The petition was duly presented in both Houses, was debated and shelved; but the Times, in an article on the subject, wrote :-

"The true idea of the Settlement, Colony, or by whatever name it may be called, is as the centre and citadel of British power in the Eastern Seas, and the great house of call between Great Britain and China." 


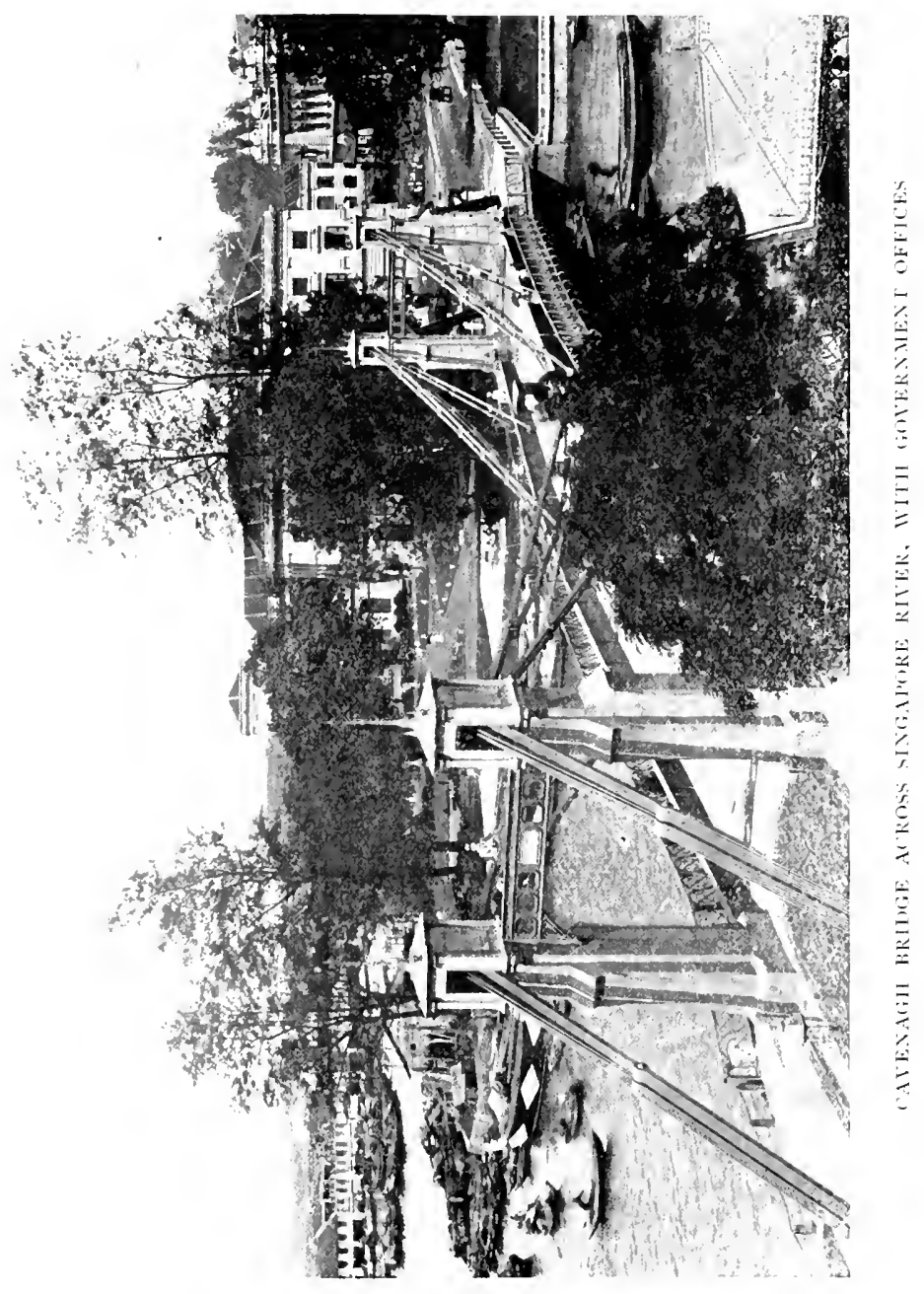



That statement is quoted because that "idea" was really the root of the whole matter, and it was not to be expected that a supreme authority in Calcutta would either realize the position, or exert itself to see that the Straits generally, and Singapore especially, fulfilled their manifest destiny. The Times realized in I 857 what English statesmen will not admit even now-that Singapore is an imperial station; though it was the insistence of people at the other end of the world, and not the foresight of the home authorities, which brought it into being.

After six years of ceaseless agitation, Sir Hercules Robinson was sent to the Straits to report whether they could afford to pay for the luxury of transfer to the Colonial Office, and then, after another decent interval of four years, the three settlements became, from I April, I 867, a Crown Colony. 


\section{CHAPTER VI}

THE STRAITS FROM I867-73

SIR HARRY ORD'S ADMINISTRATION

ANARCHY IN THE MALAY STATES

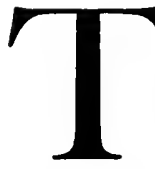

THE first Governor selected by the Colonial Office to undertake the somewhat difficult task of introducing the colonial system into a group of settlements saturated with the traditions of Indian methods of administration was Colonel Harry St. George Ord, C.B., of the Corps of Royal Engineers. It is perhaps not very surprising that Colonel Ord, who came from the West Coast of Africa, made an indifferent impression on the white population of this Far Eastern Government, and his unpopularity continued as long as he held the office. He was regarded as masterful and overbearing; extravagant in his ideas of what constituted a suitable Government House and Governor's yacht, and he neither sought the advice of the community, nor showed himself much inclined to accept it when tendered without invitation. $\mathrm{He}$ brought with him the usual Crown Colony Constitution, which comprised an Executive and Legislative Council, and in the latter the unofficial element was usually in opposition to the Governor. On the other hand, Governor Ord was a man of strong character and ability; he came to a dependency which had always been a burden on Indian finances, and he made it pay its way, and left it with a very respectable credit balance. 
The returns of Revenue and Expenditure, and the Value of Trade, in what we may henceforth call the Straits Colony, have already been given for the year I 835-6, and the progress of the settlements, up to the date of the transfer, may be gathered from the figures on the next page, far as they are from being complete.

Having regard to these figures, ${ }^{1}$ and the fact that the Government of India asserted, that the annual cost of maintaining a military garrison in the Straits amounted to $£ 300,000$, to which the dependency was only able to contribute $£ 63,000$, it is not surprising that no great objection was raised to the transfer of the Settlements to the control of the Colonial Office. This was more especially the case since Calcutta had lost interest in a place which had been acquired mainly for trading purposes. As India itself was to pass to the Crown, and be governed on new lines, it was no doubt decided that the India Office would have enough to do, without the additional responsibility of these small and distant Settlements.

Lord Canning, the Governor-General of India at the time when the agitation for transfer first began, expressed his views in an able minute in which he broadly stated the case for India and for the Straits. He wrote:-

"It must not be overlooked that the revenues of the Settlements have been steadily increasing, and that while the receipts have risen from 873,692 rupees, in $1854-55$, to $1,323,368$ in $1858-59$ (being an increase of $5 \mathrm{I}$ per cent in four years), the disbursements for civil charges, not including the cost of the foreign convicts, have in the same interval risen from 722,107 rupees to 821,913 , being an increase of 14 per cent only. As there is no reason why the civil charges of the Settlements should be further increased, it may be anticipated that, if peace should happily

1 Kindly supplied by the India Office. The expenditure figures do not include the military charges, nor, perhaps, the cost of the Indian convict establishment. 


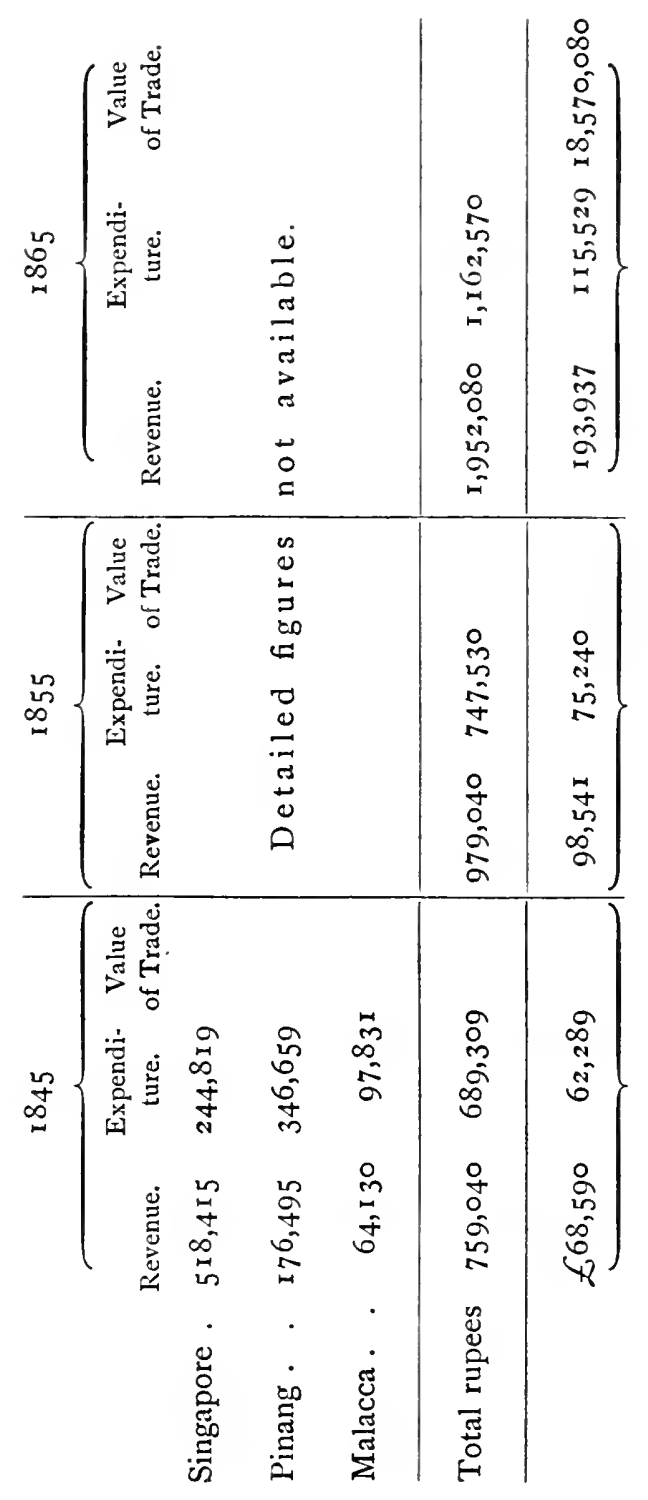


be maintained between England and the great European Powers, the revenues of the Straits Settlements will, in no very long time, equal their full charges, Military as well as Civil. But even if it prove otherwise, and if it should be necessary for England to make some sacrifice in this respect, I hold a clear opinion that it ought to be made in justice alike to the Settlements and to India."

Lord Canning evidently held the clear opinion that neither India nor the Straits should be charged for the cost of a garrison which, when once the Straits had passed from Indian to Imperial control, would cease to be an Indian concern, and could not rightly be regarded as a colonial liability; for the Imperial, and not the Colonial, Government would decide what the constitution of the garrison should be, and where drawn from. If there is any truth in the saying, "Who pays the piper shall call the tune," it would follow that, who calls the tune shall pay the piper. Lord Canning held other views, equally excellent, which probably were not endorsed by the members of the Indian Civil Service. He expressed them in a later passage of the same minute, and they apply to-day to officers whose experience has been gained in African or Mediterranean colonies, as well as they did, in 1859 , to officers with Indian training transferred for service in British Malaya. This is the passage :-

"But whether the main system of Government be altered or not, that under which officers are provided for service in the Straits is, so far as civil administration is concerned, a positive evil, which ought in any case to be remedied. Indian officers have no opportunities of acquiring experience of the habits or the language of either Malays or Chinese, and accordingly, when officers are sent to the Straits, they have everything to learn. The Government of India is unable to keep a close watch upon their efficiency; the field is so narrow as to afford 
little or no room to the Governor of the Settlements for exercising a power of selection in recommending to a vacant office; and there is consequently so complete an absence of stimulus to exertion that it may well be doubted whether Indian Civil officers sent to the Straits ever become thoroughly well qualified for, or heartily interested in the duties they have to discharge. The character of the Chinese, the most important and at times a very unmanageable part of the population of the Straits Settlements, is quite different from that of any people with whom Indian officers have to deal. . . . I am satisfied that if the Straits Settlements are to remain under the control of the Indian Government, it will be absolutely necessary to devise a plan by which the persons employed in administering the Civil Government shall receive a special training; and that without this the Indian Government cannot do justice to these Settlements."

It is curious how applicable these words of Lord Canning were to Colonel, afterwards Sir Harry, Ord; for the real mistakes he made were due to ignorance of Malay customs and affairs. It might be difficult to say how far Sir Harry Ord was responsible for the policy by which England abandoned all her interests in Sumatra, and ignored her treaty responsibilities to the Sultan and people of Achin, in return for Dutch concessions, of doubtful advantage, on the West Coast of Africa. It is, however, certain that Sir Harry Ord used all his influence to have this arrangement carried out, with the result that we were immediately saddled with the Ashanti expedition, which cost a good many lives and $£ 900,000$; while the Dutch entered, light-heartedly, into an attack on Achin which, after thirty-three years of fighting and enormous sacrifices in blood and treasure, is not concluded yet. This fact is worth remembering, in view of the attitude of the Dutch towards this country during the 


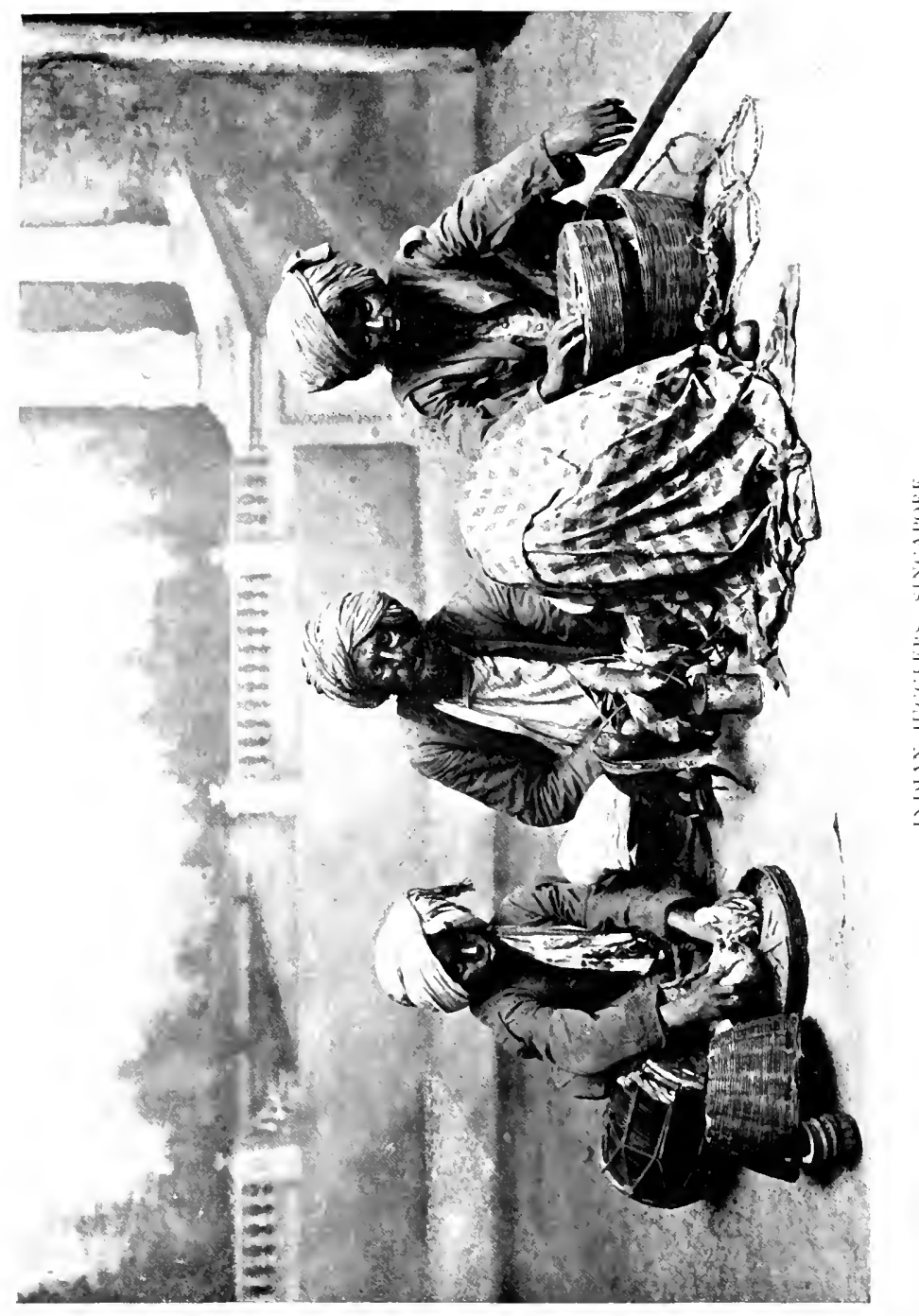



recent war in South Africa, when the two main charges against England were, that she had, without provocation, attacked an inoffensive people, in order to possess their country and deprive them of independence ; and, secondly, that it was a disgrace to British arms that the struggle should have lasted so long as it did. The last that has been heard of Dutch military operations in Achin was the slaughter of many hundreds of women and children, and the explanation given was that they were thrust to the front by the men, who sheltered themselves behind them, and, in any case, that the women were as desperate fighters as the men. If the last statement be true, it is a very significant testimony to the state of feeling of the Achinese, that their women should join the ranks and die, with their children, in hundreds, under the bullets of an enemy. It would probably be difficult to find a parallel ${ }^{1}$ in all Malay history.

1 Whilst this book was still in the press, a parallel to the incident referred to above has been supplied by a Dutch writer to the Times. I have never heard of tribal suicide as a Malay custom, and individual suicide is extremely rare. In any case, we may be thankful that the sacrifice described in the letter, here reprinted, did not take place in any Malay country under British influence.

\section{"TRIBAL SUICIDE." \\ TO THE EDITOR OF THE "TIMES."}

Sir,-May I by your courtesy be admitted to the hospitality of your columns to refute a statement I see in the Press?

In consequence of the wording of a Reuter telegram, it is alleged that the Netherland troops in Bali (not Achin, that is 1700 miles away from Bali) slaughtered about 400 people, among them a majority of women and children.

The death of so many human beings is sad enough, without the imputation of cruelty against the Netherlands soldiers. What happened is this.

All students of Malay and Hindu history know that one of the most horrid customs in those countries is the "poopootan," what I should like to call the tribal suicide.

A Bali prince, with the instincts of his warrior race, declines to surrender, but prefers death, and he with all his people seek death. The Prince of Badoeng did this. He turned a deaf ear to all suggestion of a settlement, 
This is not the place to discuss the acquisition of the Dutch Station on the West Coast of Africa. It may have been worth the Ashanti War and all that stands for; but it can be confidently asserted that the Gold Coast Colony, with its fatal climate and other drawbacks, would not compare in value with the position we held in Sumatra, if we had taken advantage of it, as Raffles intended that we should. Simply weighing the balance of advantages, they are with Sumatra, and the Dutch would not have been ready to make the exchange had they not felt convinced that they were getting the best of the bargain.

Both the Dutch and the British have paid dearly for the results of an arrangement in which those most nearly concerned were not consulted. But, apart from questions of gain, the Achinese were under the impression that we had treaty relations with them which did not admit of our withdrawal without cause and without notice. When they found themselves involved with the Dutch, the Sultan of Achin earnestly appealed to the Government of her late Majesty, but without avail. Even supposing that no question of prospective advantage was considered in making the exchange of rights (for we could not, perhaps, foresee that it meant a war between Holland and Achin, any more than the Dutch foresaw that we should be involved in a war with Ashanti), still, if the arrangement had not been made, the people of Northern Sumatra would have been spared thirty-three years of somewhat savage war-

but he and all connected with him, men, women, and children, committed suicide.

Nearly the same thing happened in 1895 in Lombok, a neighbouring island. The old King had surrendered, but one of his sons, a cripple, walked out with all his relations, dressed in gorgeous garments, bedecked with all their jewelry, and with their swords and lances attacked the Dutch army, only to find the death they courted. Those who were not killed in the fight were afterwards found to have also killed themselves.

I am, Sir, your obedient servant,

C. Thieme, London Correspondent of the

National Liberal Club, Sept. 25.

De Nieuwe Courant (The Hague). 
fare, during which many innocent people must have suffered terrible hardships, though the tale of them does not reach the outer world. Sumatra is, unquestionably, one of the richest territories in the East, and Raffles' object was to secure for Great Britain the keys of the Straits of Malacca; Achin in the north, and Singapore in the south. It looks rather like the irony of fate, that the first Colonial Governor of Singapore should have devoted much of his time, and all his influence, to undo part of the work of the Founder of Singapore. His action is curious for another reason. Pinang was, in $\mathbf{I} 867$, always had been since its early days, and is still, the principal market for the trade of Northern Sumatra. During the early years of Sir Harry Ord's administration there were several complaints from Pinang of native vessels from that Settlement being detained in the ports of Northern Sumatra, and even, in some cases, pirated by the subjects of Achin or the neighbouring States. Governor Ord remonstrated with the Sumatran chiefs, without great effect, and he may have thought that he would be relieved of trouble, and the Pinang traders of loss, if the Dutch authority was paramount in Sumatra. If so, he was prepared to make great sacrifices for small cause, and it cannot be forgotten that the first British station was established, at Bencoolen, as long ago as 1684, and the various agents of the East India Company, who resided there, never had any particular trouble with the Sumatran Chiefs.

One of the grievances made by the Straits people, in their petition for severance from Indian control, was that Raffles' principal injunction, to cultivate friendship with all neighbouring Malay States, in Sumatra, the Peninsula, and the Archipelago, and to advance British interests by friendly intercourse, had been entirely neglected. Governor Ord was no doubt aware of that complaint, and, having secured a Government yacht, he made periodical visits to the Malay States on the east coast of the Peninsula, to 
Kĕdah on the west, and he even travelled as far as Siam and Java, the latter in connexion with those Sumatran affairs already alluded to. He does not appear to have made the acquaintance of the Sultans of Pêrak or Sĕlangor till near the end of his term of office, but he befriended and took a very great interest in the Tĕměnggong Abubâkar of Johore a State, which by this time, had considerably developed, owing to the agricultural enterprise of wealthy Chinese in Singapore, who owned large and flourishing plantations in Johore, where they cultivated the pepper vine, and a shrub called gambir, from the leaves of which is extracted a valuable dye.

In the history of the Straits, few things are more remarkable than the gradual loss of interest in, and knowledge of, the neighbouring Malay countries. We have seen that research into everything Malay was the guiding force of Raffles' life ; to know the people, their language, customs, and literature, were his greatest interest and delight; in fact, his whole official career was divided between this study of the Malay and the determination to gain for his country a share of that trade and influence which every day was becoming more of a Dutch monopoly. Raffles' example seems to have stirred a good many other contemporaries to similar pursuits, and men like Marsden, Crawford, Logan, and Braddell studied and wrote upon a great number of subjects affecting their immediate neighbourhood, and countries as far afield as Borneo, Siam, China, the Philippines, New Guinea, and Australia. This admirable enthusiasm continued till 1860 , by which time nearly all the leading contributors to what may be called the English literature of Malaya had disappeared from the Straits. Mr. Braddell alone remained, and was in the Straits during the whole of Sir Harry Ord's administration; but his duties as Attorney-General occupied all his time, and left none for further research into those subjects to which he had formerly given his leisure. 
In the first years of the colony's history, from I 867 to 1874, it is almost inconceivable how little was actually known of the independent Malay States in the Malay Peninsula. It would not be too much to say that in the colony there was probably not a European, and very few Malays, who could have given correctly the names of all the States in the Peninsula, from Singapore to the southern boundary of Siam. Similarly, no one could have stated, with approximate correctness, how all the States should be placed on a map, nor what were the real titles of their rulers. What was understood was that, in many of the States, there was going on some kind of domestic struggle between rival claimants to power who, from time to time, as they could raise funds or gain credit, sent to the colony for arms and ammunition to carry on a warfare which claimed comparatively few victims, and in which the fortunes of the combatants varied with bewildering rapidity. Meanwhile the country was being depopulated more by emigration and disease than by the numbers slain, and only very rash people were so foolish as to thrust their heads into such a hornets' nest, in spite of wonderful tales of its mineral riches. Indeed, when some of those who had unwisely made advances of money or material to Malays and Chinese within the zone of disturbance, appealed to the Government to assist them to recover their debts or their property, they were met with the reply :-

"If persons, knowing the risks they run, owing to the disturbed state of these countries, choose to hazard their lives and properties for the sake of the large profits which accompany successful trading, they must not expect the British Government to be answerable if their speculation proves unsuccessful."

Johore, at this time, was tranquil ; indeed, it was only sparsely peopled, and it was too close to Singapore for the making of trouble. As already stated, Governor Ord took a great personal interest in the Těmĕnggong, and he 
advised him on all important matters of administration, making it understood that the advice was to be followed, as indeed it was, almost invariably. Before Sir Harry Ord had been twelve months in the Colony the Tĕmenggong wrote to him a letter suggesting that, as the inferior title of Termĕnggong was altogether inapplicable to the Sovereign Ruler of Johore, it should be abandoned. The Governor forwarded the request, with a strong recommendation that it should be granted, and on 20 May, I868, the Duke of Buckingham and Chandos replied :-

"... In reply, I have to instruct you to inform $\mathrm{His}$ Highness that Her Majesty's Government have much pleasure in acceding to his wishes that the title of Maharaja of Johore should be adopted in the place of that of Tumongong, and you will consider yourself therefore at liberty to use that title in future."

The title "Maharaja" is common in India, but unknown as applied to Malay rulers.

A reference to the map will show that there are on the west coast of the Peninsula, between Kĕdah in the north and Johore in the south, three Malay States, namely Pêrak, Sělangor, and Něgri Sambillan, which means the nine States. The boundaries of these States have been altered since they came under British protection; a tract of country called the Dindings, seventy miles south of Pinang, has become British territory, and a coast district, called Lukut, formerly under Sělangor, is now a part of Nĕgri Sambilan. These three states, counting the Nĕgri Sambîlan as a whole, had for years been given up to internal strife, and it will be necessary to explain the causes of the various quarrels.

The outside world knew and cared very little about it, and if the combatants had confined their attentions to their own countries and refrained from molesting British subjects, it is quite possible that they might have killed each other to the last man without our interference. 


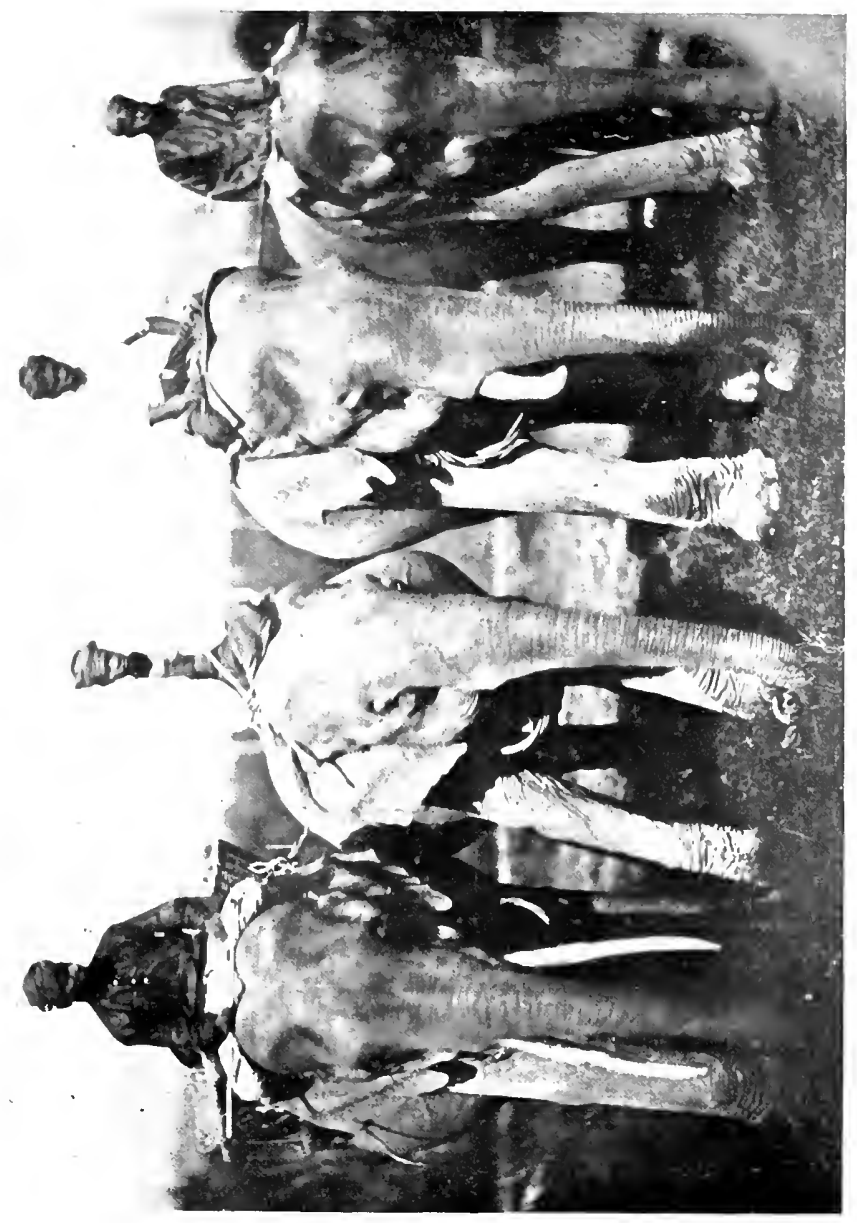

资 

Letters imploring assistance, and offers to hand over their States to the Company or the British Government, had been made at intervals ever since the occupation of Pinang. The former had been disregarded and the latter politely declined, partly because no one urged that any special advantage was to be gained by undertaking such responsibilities, partly because people in authority were always afraid of offending some other power, and partly because it was recognized that any such proposal would be declined by the home Government. Towards the end of Sir Harry Ord's administration, the disturbances in both Pêrak and Sĕlangor began to affect persons and interests outside those States. In I 87 I the piracy of a British trading boat by Chinese and Sĕlangor Malays was reported, and when the Senior Naval Officer, in H.M.S. Rinaldo, went to the scene, and an endeavour was made to arrest persons identified as having taken part in the outrage, a struggle ensued, the Government vessels were fired upon by forts at the mouth of the Selangor River, and these forts were destroyed by the Rinaldo. Sir Harry Ord was then in England on leave of absence, but he returned to his post in 1872 , and finding the state of affairs in Selangor as bad as could be imagined, he endeavoured to use his influence to secure a cessation of hostilities. In this, however, he failed. In Pêrak matters were even worse, though the trouble was not of such long standing. There was a Malay quarrel about the succession to the sultanship, and a continuing fight, with very heavy losses on both sides, between two factions of Chinese, who were struggling for the possession of valuable tin mines. Both sides had friends amongst the Chinese in Pinang; these tried to furnish them with the sinews of war, and Pinang was invaded by two thousand wounded and starving people who had escaped from Lârut, the district of Pêrak where the most serious fighting was taking place. 
This was the condition of affairs in the end of 1872 , and in the following months, up to the time when Sir Harry Ord's term of office expired, in the autumn of 1873 , it grew much worse.

It is difficult, without wearying the reader, to give a comprehensive sketch of the causes which produced such a situation that the British Government reluctantly consented to authorize a new departure, and, forsaking the policy of rigid abstention, to make trial of some method by which peace and order might be introduced into the affairs of these unruly Malays, without committing the local or Imperial Government to any serious responsibility. The difficulty cannot be avoided; for the principal aim of this narrative is to show the nature of the Malay case which British officers were set to deal with, how they handled it, and the result.

Pêrak is a large State, covering about eight thousand square miles of territory. Its back is towards a great range of hills, some of them eight thousand feet high, running down the centre of the Peninsula, whilst it faces the Straits of Malacca, with a coast line about eighty miles in length. Speaking very roughly, the northern boundary of Pêrak marches with Province Wellesley and Kĕdah, while the southern boundary is a considerable river, the Bernam, dividing the territories of Pêrak from the adjoining State, Sělangor.

It will be understood that Pêrak and the other western States are drained by many large and small rivers, rising, for the most part, in the main range of mountains, and flowing, westward, into the waters of the Malacca Straits. Similarly the eastern States are drained by rivers, rising in the same mountain range, but flowing eastward into the China Sea. The principal river of Pêrak is a very fine stream, navigable to boats for about two hundred miles; it bears the same name as the country, and it falls into the Straits of Malacca just south of the 


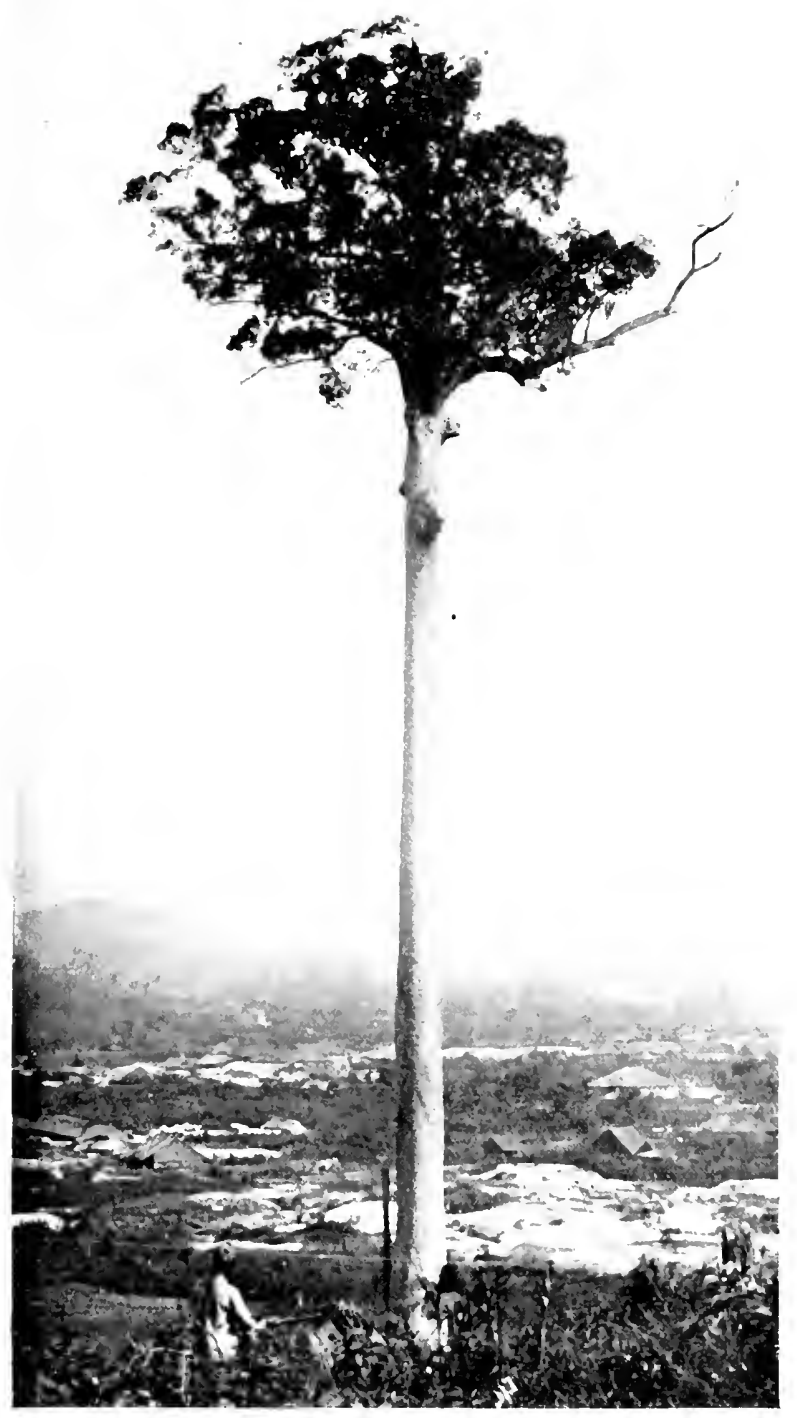

LOOKING WIER IHE MINES IN IARTT 

Dindings territory. On this river and its tributaries live by far the largest proportion of the Malay inhabitants of the country. The river is deep and tidal, and for the first thirty miles of its length from the sea is navigable for steamers. The country on either side is flat, swampy, and low, and the shore of the State, except the Dindings, is lined continuously with a broad belt of mangroves. At the time of which I am now writing, 1872-3, there were few Malays in this lower country; but there were, dotted along the coast, villages of Chinese fishermen over whom no one exercised any particular control. Above that first thirty miles of the Pêrak River the water ran clear as crystal over its sandy bed, and it was for the most part very shallow, with deep pools at unexpected places. For the next hundred and fifty miles the width of the stream varied from about seven hundred yards to seven hundred feet or less; it was dotted with islands, some of fair size, and, while the lower reaches were often bounded, on one side or the other, by long stretches of russet sand, the further the river was ascended, the higher became the banks, till they maintained a uniform height of about twenty feet from the ordinary level of the water. Throughout the whole of this riverlength were villages, large and small, usually divided from each other by several miles of heavy forest, and each village was the residence of an important chief, or under his control. Fifty miles from the sea the conformation of the country changed; small isolated hills were seen close to the river, while the spurs of ranges, rising to two thousand or three thousand feet, ran down to the water's edge. A hundred and fifty miles from its mouth the river forced its way through a succession of gorges and the navigation was difficult, on account of the numerous rapids. In the upper country, however, the villages were far apart and the population scanty. To the north of this great valley of the Pêrak River was a district called Lârut, drained by an insignificant stream. North of that again was the Krian 
district, which marched with Province Wellesley and Kĕdah. In Krian there were a few agriculturists, and on the coast a few fishermen. Inland was a sub-district called Salâma, where some tin mines were being worked, partly by Chinese and partly by Malays.

Lârut was the great tin-mining district of Pêrak. It contained a population of about twenty thousand Chinese and two or three thousand Malays. The mines lay at the foot of a great range of jungle-covered hills (rising, in their highest point, to over five thousand feet), and were distant from the navigable estuary of the Lârut River about ten miles, with another ten miles to the open sea. Speaking broadly, there were two groups of mines (all open-surface workings), about two miles apart, worked respectively by the Go Kuans (the five tribes) and the Si Kuans (the four tribes). In the whole of Pêrak, at this time, there was only one road, about twelve miles long, passing from the Si Kuan mines, through the Go Kuan village, down to the landing-place on the river estuary. From the middle of this road there was a branch of six miles to the village and residence of the Malay chief of the Lârut district. This man was styled the Mantri, and he was one of the four high officers of State.

On the southern side of the Pêrak Valley there were three districts. First, Kinta, drained by a river of that name, which joined the Pêrak River some forty miles above the mouth of the latter stream. Kinta was well populated by Malays, and had a few rich tin mines, some of which were worked by Chinese. Then came a district called Bâtang Pâdang, with a stream which also joined the Pêrak River a few miles below the Kuala Kinta, meaning the mouth of the Kinta River. There were very few inhabitants in the Bâtang Pâdang district, and fewer still in Bernam, which comprised a huge stretch of virgin forest on the left bank of a great river of the same name, the boundary between Pêrak and Sĕlangor. 


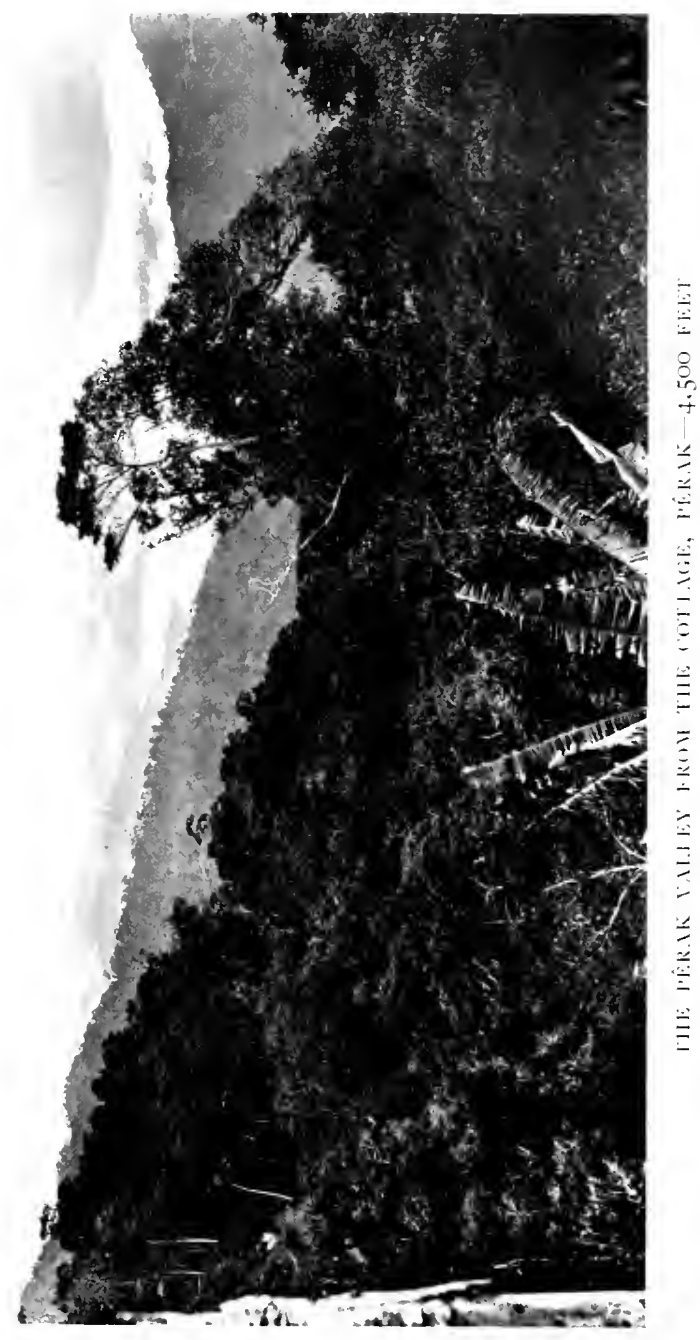



Will the reader try to realize the general appearance of this country before I tell him the nature of its rule, the condition of its people? I can no longer refer him to the authority of others. All that follows was the result of my own observation, often of my very bitter experience; and when I write of events in which I did not personally take a part I had, I believe, the best means of knowing what actually took place.

Here, then, was Pêrak, a "limitless expanse" of jungle ; miles upon miles of forest, broken only by silver streaks, where one might, from a very high place, catch glimpses of some river. A few patches of lighter green showed where there were, or more probably had been, clearings. Excluding the single district of Lârut, there was not a yard of road in the country, and hardly a decent house; there was not even a bridle path, only jungle tracks made by wild beasts and used by charcoal-burners and a few pedestrians. The commerce of the country was by the rivers; they were the highways, and the people would not leave them, unless they were compelled to do so. The country folk moved about but little, for they knew the difficulties too well. A boat journey of a hundred miles down river would take a week, and back again a month or more. When people of consideration had to journey by land, they travelled on elephants, if they could get them, and cut their way through the jungle. Pedestrians had to foot it as best they might; over the roots, through the thorns, wading or swimming rivers and streams, ploughing through miles of bog and mud in the heat and rain, stung by everything that stings (their name is legion), and usually spending two or three nights in the jungle with any kind of shelter that a chopper and the forest could supply. As for food, the traveller or his people carried it, and even in villages it was practically impossible to buy anything except an old hen. The Malay villages, always on the bank of a stream, were composed of palm-thatched 
wooden huts raised above the ground. These huts were scattered about, without the smallest attempt at regularity, in orchards of palm and fruit trees, no attempt being made to clear the undergrowth of weeds and bushes.

There would be a mosque-perhaps two, if the village was large-and behind it, in a swamp, there were usually some rice fields. The people lived on what they could catch in the river or the swamp, on the fruit of their orchards, on such vegetables as would grow without tending ; poultry and goats were a luxury. In the neighbourhood of mines it was a little better, because it was possible there to sell what they had to Chinese. But there again was a drawback, for, like vultures to a carcase, all robbers, thieves, and murderers collected round the mines ready to despoil, by every means, any one who possessed anything worth taking. If there was a complaint (poor people knew better than to make one), and the parties were hailed before some chief or raja, or swash-buckler with a few determined followers, the result usually was that everybody concerned returned poorer than he went.

For authority and justice there ought to have been a Sultan, the seventeenth of his line, for Pêrak is a State which prides itself upon the antiquity and completeness of its rules and customs; but, then, so do Păhang and Kĕdah, though it is certain that, in Pêrak, there has survived the most perfect organization of State officers, each with welldefined duties; only, in 1872, the duties were ignored and the titles were simply used as a cover for the exercise of a large authority. As for Sultans there were three, and that was the root of the whole matter. Not even an independent Malay State can put up with three masters without a good many tears.

There was little fault to be found with the constitution of Pêrak; the trouble was with the holders of office, the disappointed, the unruly, and the foreign freelances, who found the place exactly to their taste; while the poor 
groaned and suffered, and there was no one to listen to their exceeding bitter cry. Ancient custom provided that the State should be ruled by a Sultan-if possible, the eldest legitimate son of a previous Sultan, and he was supported by two dignitaries, also of royal birth, the Raja Muda and the Raja Bĕndahâra. The former of these was supposed to be the head of all those of Raja birth, and the latter was the Sultan's Wazîr, his Prime Minister. There was another post, of no great importance, with the title of Raja di Hilir, that is, the Raja of the lower, or down-stream, country, and this office was, or ought always to have been, held by the eldest son of the reigning Sultan. The office of Raja Bĕndahâra was held by the eldest son of the last Sultan, and that of Raja Muda by the eldest son of the Sultan before him. So, when a Sultan died, he was succeeded by the Raja Muda, and the Raja Běndahâra and Raja di Hilir each moved up a step, the son of the new Sultan being in due time appointed Raja di Hilir. By this means the country was always supposed to secure in its Sultan a man of considerable experience, who had held three high offices, who knew the State, its people, its customs, and its needs, and who, if he failed during the period of probation to prove his worth (in other words, if he turned out an irreclaimable scoundrel), would be passed over and left in the stage at which he had arrived. Should that occur, as it sometimes did, the son of the rejected did not necessarily suffer for the sins of his father, but might, in his turn, be appointed Raja di Hilir, when his ultimate destiny would be in his own hands.

Under the Sultan and his two royal props-as Malays call them-were four great chiefs, of whom the Mantri (with Lârut as his charge) was one, the Sri Adika Raja, or Chief of the Upper Country, another, and the Tĕmĕnggong the last. Under these, again, were eight chiefs, at the head of whom was the Maharaja Lela (of whom there 
is more to tell later on), the Laksamâna (the Admiral), the Shahandar (Port Officer), the Dato' Sagor, and others. Last of all were sixteen minor chiefs, with sufficiently high-sounding titles and real duties, if they had ever performed them. Besides all these, there were Court officials, priests, village head-men, and so on.

To come from the abstract to the concrete. It happened that when the last Sultan but one, Sultan Jafar by name, died, and was succeeded by Sultan Ali, a certain Raja Yusuf, son of a previous Sultan, was passed over; his junior, Raja Abdullah, was created Raja Muda, and a foreigner, a man called Raja Ismail, whose mother only belonged to the Pêrak royal family, was created Raja Bĕndahâra. It was said that Raja Yusuf was passed over on account of his unpopularity, and I can believe it, for I knew him very well. He retired to his own village in high dudgeon; but as he could get no support there was nothing to be done. Then Sultan Ali died, and this time Raja Abdullah was passed over, and the foreigner, Ismail, was created Sultan by a certain number of chiefs, of whom the Mantri was the leader. The excuse given in this case was that Abdullah neglected to attend the burial of Sultan Ali, and as it was the custom that a dead Sultan could not be buried until his successor had been appointed, the chiefs present acknowledged Ismail. They also said that, when his wife was carried off by a Sĕlangor Raja, Abdullah had neglected the opportunity offered him of revenging himself on the abductor and bringing his wife back again. As to the first plea, it is unsound; for it had not been the invariable custom in Pêrak to install the successor before burying a deceased Sultan, and Abdullah had excuse for his non-attendance. The second plea was not publicly advanced.

The real reason why Ismail was acknowledged by a number of up-country chiefs (many of whom had just received, or been promised, office) was that the Mantri 
willed it so. The Mantri, as already stated, was the chief of the Lârut district, and owing to the extent of the tinmining industry in that province, he was far the richest and most powerful individual in Pêrak. The Mantri himself was not a pure Malay; he was partly Indian, and the Indian blood gave him a shrewdness and business capacity foreign to Malays. He, no doubt, calculated that if he could get his friend Ismail, a foreigner and an old man, elected Sultan, there was no special reason why he might not, in the fullness of time, step into his friend's shoes. The Mantri was a travelled person, with a house in Pinang, and he may have drawn his inspiration from observation of passing events outside Pêrak. In any case Ismail received a certain amount of acknowledgment, though Abdullah had a fair following in his own country, down-stream.

As may be supposed, Abdullah was beside himself with fury, but as he was not a very bold man, and did not possess sufficient resources to make a fight of it, he caused himself to be acknowledged Sultan by his own party, and at the same time made overtures to Raja Yusuf, the discarded, and appointed him Raja Muda. In doing this he, no doubt, thought that he would secure a fighter for his side (though Yusuf had neither means nor followers), and Abdullah sent him to Lârut with a handful of men to support those who were in opposition to the Mantri. Then Abdullah wrote to the Governor of the Straits, stating what had happened, asking to be recognized as Sultan, and also requesting that a British officer might be sent to him to teach him the art of administration.

Whilst all this was going on, affairs in Lârut had got into a desperate state. The rival factions of Chinese had quarrelled about the mines-some said about a woman. The cause is of no particular importance, but the result was a pitched battle, and three thousand men were said to have been killed in a single day. The villages and 
every isolated house had been burnt down, almost every mine had stopped work, and the combatants had stockaded themselves in what they considered the most advantageous positions. The Mantri and his distant village were left unmolested, and, as his influence and authority were not sufficient to re-establish order, he espoused the cause of one side, the Go Kuans, and gave them all the assistance that he could. The Si Kuans had seized and stockaded positions between the Go Kuans and the sea, but as the Mantri owned two small steamers and was the recognized authority in Lârut, he kept his friends supplied with food and arms, and attempted to starve the other side into submission. Amongst these miners were many criminals, pirates, and desperadoes from the South of China, and steps were at once taken to increase their number. The Si Kuans were probably the best fighters, and their friends in Pinang did all they could to help them. They sent Chinese junks, loaded with arms and food, to out-of-the-way places on the coast, and tried to get the supplies forwarded by creeks, rivers, and overland. All this was, of course, done secretly, but, in spite of such assistance as they could get, the $\mathrm{Si}$ Kuans were driven to the most desperate straits, suffered terribly, and took to piracy to relieve their necessities. As far as fighting went they would not give in, and their opponents had not the courage to attack them in their stockades and make an end.

Hoping to settle matters, the Mantri had bought some Krupp guns and engaged the services of Captain T. C. Speedy, of Abyssinian fame, to recruit a number of Indian warriors (mostly Punjabis, Afghans, and Sikhs), and they were in a stockade on the branch road, about four hundred yards from a Si Kuan stockade built at the junction of the roads.

There had been several naval engagements off the coast of Lârut, between rival fleets of junks, and many 


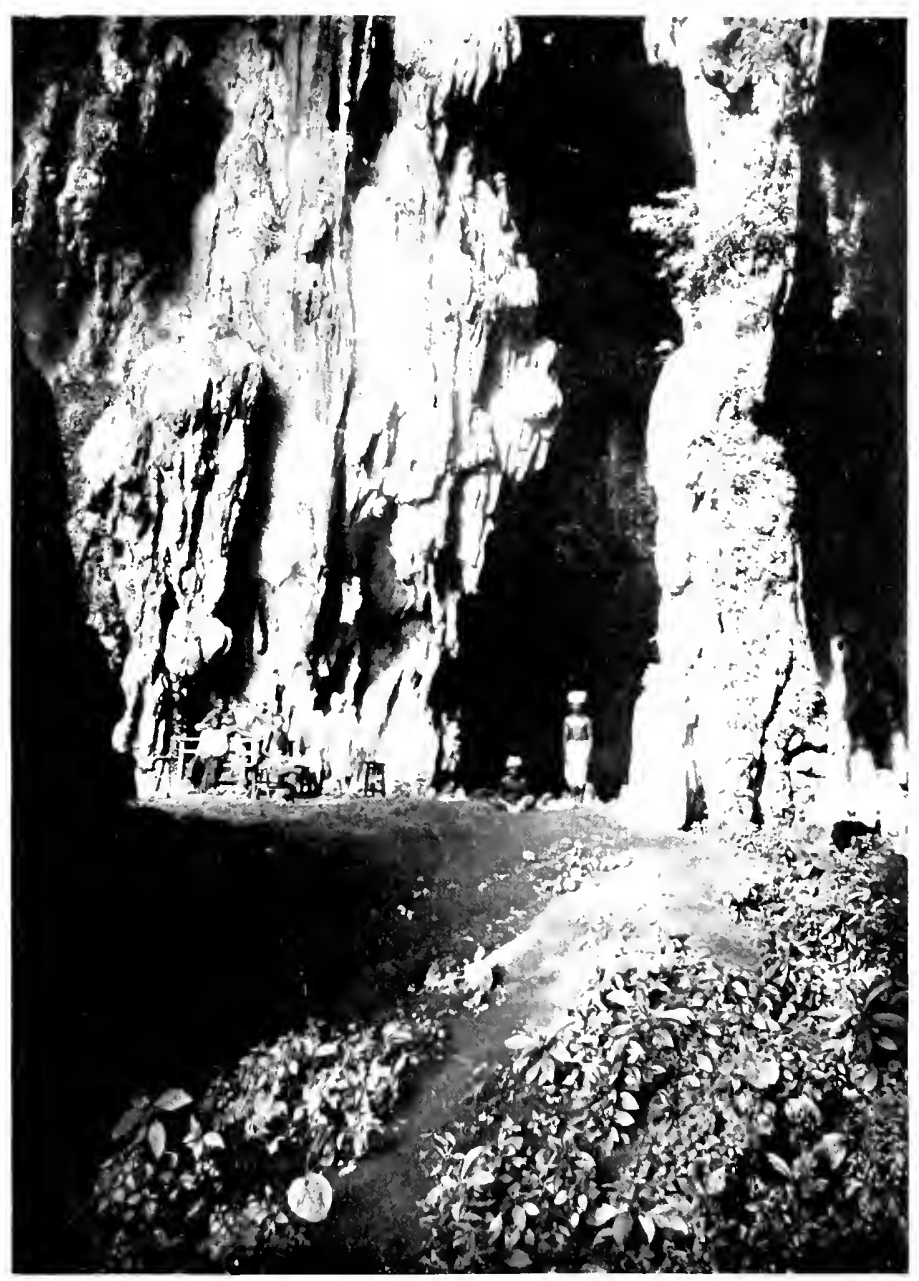

GREAT CIVES AT BATU, SELÂNGOR 

lives had been lost. The Si Kuans established a fort in the jungle, on the Lârut River, and from this vantage ground they commanded the river, attacked all boats, and fired on the Mantri's steamers. As months went by, and this lamentable state of affairs continued, the Si Kuans fitted out a number of long and fast fishing-boats, which, with guns and fighting platforms, fore and aft, and doublebanked oars, were used to prey upon all native craft navigating the Straits of Malacca in the immediate vicinity of the coast of Pêrak. No one was safe, all classes and nationalities were treated alike, and almost daily came in reports of vessels pirated and burnt, the crews murdered, and the cargoes stolen. A real panic was established, and not without cause. For months one or two of H.M.'s gunboats had patrolled the coast of Pêrak; but, as these vessels could not approach the shore, owing to the immense mud banks which stretch far out to sea, manned and armed boats were sent away, for days and nights together, in search of the pirates. The duty was an excessively trying one, the men being exposed, without the smallest protection, to the terrible heat of the sun all day, with very often deluges of tropical rain all night. I tried it for three weeks, so I know what it was like. It was impossible to land, for the coast was nothing but mangroves and mud, with here and there a fishing village, inhabited, no doubt, by pirates or their friends, but with nothing to prove their complicity. These mangrove flats were traversed in every direction, by deepwater lagoons, and whenever the pirates were sighted, as not infrequently happened, and chase was given, their faster boats pulled away from their pursuers with the greatest ease, and in a few minutes the pirates would be lost in a maze of water-ways, with nothing to indicate which turn they had taken. The whole business became somewhat ludicrous when native craft were pirated (usually by night) under the eyes of the British crews, 
and when their boats got up to the scene of action there was not a trace to show what had occurred, or where the pirates had gone. Finally the boats of H.M.S. Midge were attacked in the estuary of the Lârut River, and after a longish engagement the pirates were beaten off, having seriously wounded two British officers. The net result of these excursions was, that about fifty per cent of the crews of the gun-vessels were invalided, and not a single pirate boat or man had been captured; but the Si Kuan stockade in the Lârut River and several junks had been destroyed. It will be understood that honest people did not frequent either the land or the waters of Lârut at this time, and, if necessity drove them that way, they went warily and, for their own sakes, shot at sight.

Not content with their exploits in Lârut and the Straits of Malacca, the Si Kuans attacked British police stations at the Dindings and in Province Wellesley, and they, or their emissaries, blew up by night the Mantri's house in Pinang, hoping to rid themselves of the man who had taken the part of their enemies.

Now turn to Sĕlangor. Whilst the Pêrak disturbances and quarrels had only been active for a few years, those of Sělangor had been in progress for at least a generation. There had been intervals of comparative quiet, but the normal state of Sělangor was robbery, battle, and murder. The people of the place rather prided themselves on their reputation, and the conditions of life had made all men fighters, while even the women would sometimes use deadly weapons under the spur of jealousy. As for the country it was divided into six districts, each drained by a river of the same name; they were, from north to south, Bernam, Upper and Lower Sělangor, Klang, Upper and Lower Langat, Lukut, and Sungei Raia. Except in Lukut and Sungei Raia, the rivers were all considerable, tidal in their lower reaches, where they were navigable to small steamers, and, above that, to cargo boats. Every river on 
this coast, with one exception, has a shallow water bar; the exception is the Klang River, the mouth of which is protected by two long islands. As to the general appearance of the place, it was similar to Pêrak, but the low country was more extensive, there being but few ranges of low hills, while the distance from the sea to the foot of the main range was about forty miles, throughout the length of the State. The coast line of Sělangor extended to a distance of about I4O miles until Lukut and Sungei Raia passed to the Něgri Sambîlan by a rectification of boundary.

Bernam was practically uninhabited, except for one small village on the Bernam River, some twenty-five miles from the sea. On the left bank of the Sĕlangor River, by its mouth, was an old Dutch fort, on an isolated hill. At the foot of this hill, up river, and also on the right bank, were a few cocoanut plantations and rice fields with a scattered population of Malays. Seven miles up the Klang River there was a small town, guarded by a fort on a low hill. The town possessed a few streets, or roads, and one respectable house. On the coast were a few Chinese fishing villages, and the Sultan and his people lived in a miserable swamp by the Langat River, while the Raja of Lukut had a dilapidated house in his own district. Up-country there were some tin mines (worked mainly by Chinese) at wide intervals along the foot hills of the main range, but, at a place called Kuala Lumpor, on the Klang River about seventy-five miles from its mouth, was a Chinese town, with two streets, and a considerable number of shops and houses, built of adobé and thatched with palm leaves. From this centre, Kuala Lumpor (now the principal town in the Malay States, and the head-quarters of the Government), there were a few miles of rough, unmetalled, cart-track, running north and south, to other smaller mining camps. For the rest there was unbroken forest and a very sparse population. 
Sĕlangor had a Sultan, but practically no constitution. The Sultan was a very old man and quite a curiosity in his way. He was supposed to have killed ninety-nine men with his own hand, and did not deny the imputation. He had secured his position by violence, ousting a Raja with a better hereditary claim, and he had held the office for about thirty years by his uncompromising reputation. This was rather strange for, in 1872 , he was living in retirement in a mud swamp on the bank of a melancholy tidal stream, and his manners were as mild as those of a missionary. He was then over sixty years of age, a small, spare, wizened man, with a kindly smile, fond of a good story, and with a strong sense of humour. His amusements were gardening (in which he sometimes showed remarkable energy), hoarding money and tin, of which he was supposed to have a very large store buried under his house, and smoking opium to excess. He was not a rigid Muhammadan, for he was fond of snipe, and, as I lived in a Malay hovel in the swamp quite close by, I used to shoot snipe for him in the season, and all the Sultan asked was whether I had said "Bismillah" as I pulled the trigger. If I had, they were halal, and he could eat them. I rejoice to think that, in spite of the difficulties of his position, he lived to the age of ninety-three-gardening and hoarding and smoking opium to the last-and died mourned, not only by his own people, but by all who knew him.

In the distressful times to which we must return, the Sultan of Sĕlangor reminded one of Old Mother Hubbard. He not only had a large family (mainly grown-up sons), but they were singularly unruly, not to say wicked. Then there was a host of male relatives and connexions, also grown up, and the difficulty of finding employment and incomes for these aspirants to place and position was so great that, when they took to quarrelling, as they seem to have done at a very early age (or they perpetuated some older quarrel of their ancestors), the Sultan probably 


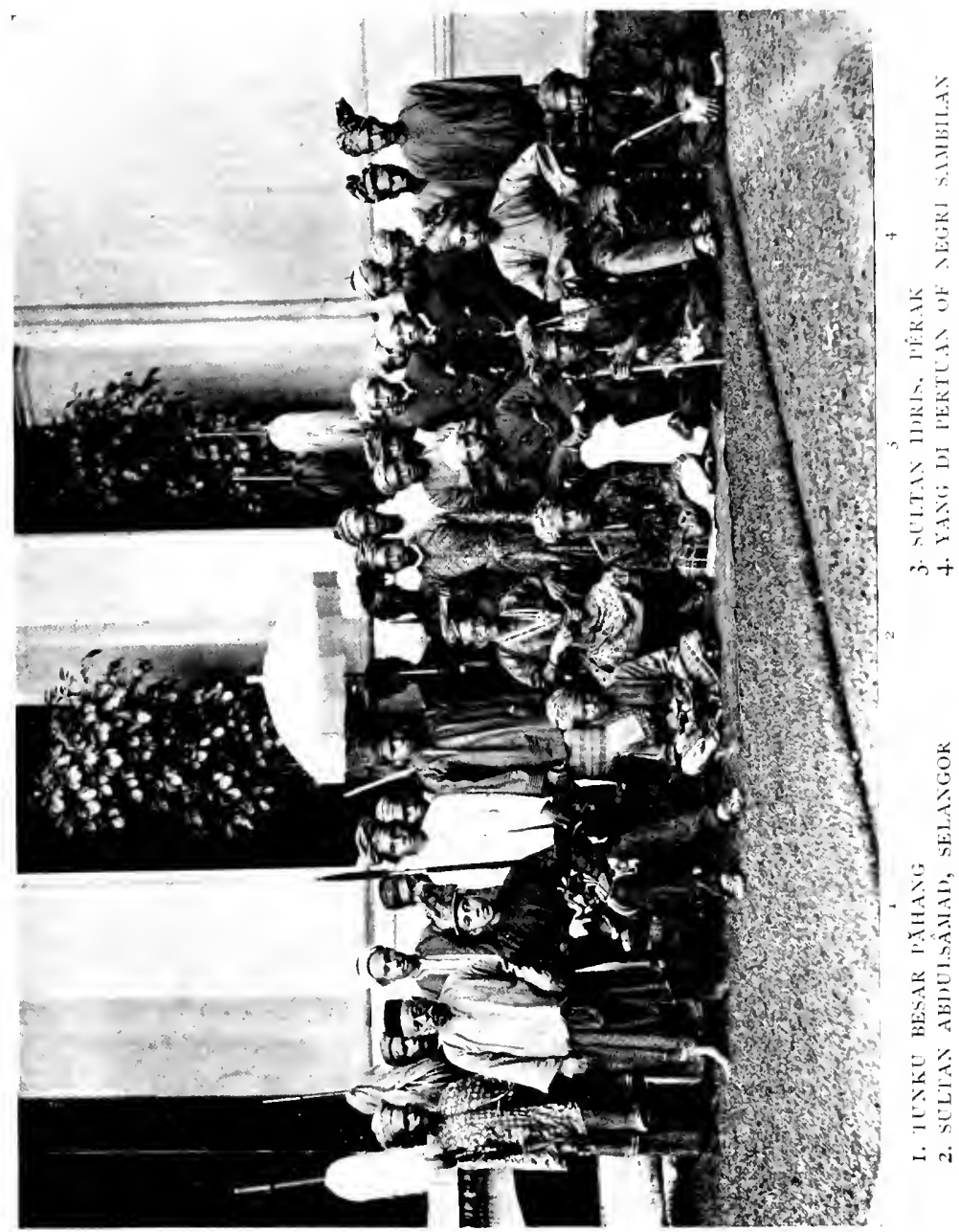



decided that his own real tastes were agricultural. It was unfortunate that his example found no imitators; for in all the Peninsula there was not a spot where life was so uncertain as in that mud swamp. It must have been the atmosphere of Sĕlangor, as much as its ancient and evil reputation, which made all men fighters; even the Chinese, first, no doubt, for their own protection, and afterwards for the excitement of the game, were almost as keen as the Malays. The one considerable body of Chinese lived in and around Kuala Lumpor, and as they were the only workers in the country, and their single means of communication with a market was by the Klang River, they had made friends with three Rajas (the sons of the Chief of Lukut), who held the village and forts of Klang. These brothers were driven from their position by three famous warriors, Raja Mahdi, Raja Mahmud, and Seyyid Mashhur, whose names were, to the western Malay States, what that of the Black Douglas was once to Scotland.

Just at this time the brother of the Sultan of Kĕdah married a very comely and intelligent daughter of the Sultan of Sellangor, and as a marriage of this kind entails a long residence at the home of the bride, the Kĕdah Raja thought he could improve it by introducing order into the disordered household of his father-in-law. He therefore persuaded the latter to appoint him Viceroy of Sělangor. That was all very well, and there the Sultan washed his hands of the business and returned to his garden; but while the discomfited brothers were quite ready to acknowledge the new Viceroy, the other party laughed at him, took all the tin which came down the Klang River, and sent their friends to attack the Chinese at the mines. The Viceroy had supporters in the colony, both Europeans and Chinese, and, with their money and the countenance of the Straits Government, he succeeded in retaking Klang and relieving Kuala Lumpor. The 
curious thing was that each party in turn and each individual leader made periodical visits to the old Sultan, complained bitterly of the other side, and asked for tin or money, arms and ammunition. To all comers, from whatever quarter, the Sultan seemed always to signify his approval, and, with strict impartiality, made gifts of some sort. All the combatants, therefore, declared that they were acting with the sanction and authority of the Sultan. Long afterwards I asked the Sultan what it meant, and His Highness explained, with a smile, that when people came and bothered him with long statements, to save discussion and get rid of them quickly he said, "Bĕnar, bĕnar," which means "Right, right"; but, he added, "I mean right from their point of view, not mine."

The fact that one or other party held this or that position was of no importance. Driven from Klang, the famous three retired to the Sělangor River ; checked at Kuala Lumpor, they withdrew deeper into the forest, the better to make another spring. So the "war" waged backwards and forwards, and just as the Mantri, in Larut, hired Indian mercenaries to fight for him, so the Viceroy of Sellangor collected a cosmopolitan band of Europeans and Easterns, and sent them to hold the mines. Very few of them ever returned, for they were attacked and broke, followed false guides and were cut off in detail, or died miserably in the forest. About that time I paid my first visit to Kuala Lumpor; it was a pleasure trip, not an official duty. I had a companion, and it took us three days and nights, poling up river, to reach Kuala Lumpor. On our return, after twelve hours' walking, miles of it up to our waists in jungle swamps, we reached a point on the Klang River where we got a boat to take us back to Klang. That was the jungle where the "foreign legion" was lost, and as they were all strangers it was not surprising.

The Chinese, under a very able captain, had their own 
way of doing their part of the fighting. Standing before an open shed in the market-place of Kuala Lumpor, and pointing to a kind of table, the Captain said to me, "That is where I pay for the heads of the enemy; every head brought in and placed on that table is worth $\$ 100$, and sometimes it has been as much as I could do to count the money fast enough."

After borrowing and spending a great deal of money; after months and years of struggle, with ever-varying fortune, the Viceroy found himself deeply indebted, and no nearer success. As a last resource, he asked the Bendahâra of Păhang to help him, and that potentate, when the request was backed by Governor Ord, agreed to send three thousand men over the dividing range, to take the Viceroy's opponents in rear. This move was generally successful, but it introduced into unhappy Sĕlangor a new element of trouble.

Of the Nĕgri Sambîlan it is not necessary to say much. Behind Malacca, and between Sellangor, on the north, and Johore, on the south, were nine little States, named Sungei Ujong, Rěmbau, Johôl, Jĕlěbu, Jĕmpôl, Gĕmĕncheh, Sri Mĕnanti, Gûnong Pâsir or Inas, and Ulu Muar. In former times these places were a part of the ancient kingdom of Johore, but so long ago as 1773 , owing to their peculiar customs and the trouble they gave, they were placed under the general control of a Raja from Měnangkâbau, in Sumatra, with the title Yang di Pertuan, the domestic government of each little State remaining with a local chief. Several of the States were fertile and well cultivated, Rembau alone had ten thousand Malay inhabitants and Sungei Ujong was rich in tin. As all these places were inland, the inhabitants could only get to the Straits of Malacca by the Linggi River in the north, or the Muar River in the south. The Linggi River is the northern boundary of Malacca, and about five miles from its mouth divides into two branches, the northern branch draining Sungei Ujong, 
and the southern Rĕmbau. The command of this waterway was everything to Sungei Ujong and Rĕmbau, and there was constant fighting for its possession. During these periods both sides built stockades on the banks of the river, and levied toll on all passers-by, Malacca traders being the principal sufferers. By 1872 the nine States had drifted apart and had not even a nominal head; there were two claimants to the post of Yang di Pertuan (the succession being, by Měnangkâbau custom, through the female line), and neither had influence enough to get himself recognized. In Sungei Ujong there were two chiefs, the Dato' Klâna, or land chief, and the Dato' Bandar, the water chief. They were supposed to have equal authority over different divisions of the State, but the Klâna, being a Seyyid, was trying to assume control over the Bandar, who refused to admit his pretensions. None of these circumstances made for peace and order; and if it be added that a change in the holder of the chief office in each little State almost invariably resulted in a struggle amongst the claimants to the succession, some idea may be gathered of the conditions of life in the Nĕgri Sambilan.

So when Sir Harry Ord left the colony, in I873, there was not only the promise of trouble, it had arrived, in over full measure; and in the brief period which elapsed between his departure in October, 1873 , and the arrival of his successor, the plot so thickened that it might truly be said the western States of the Peninsula, from Pêrak to the borders of Johore, were given up to native warfare, with all the evils and miseries that follow in its train. At the same time, the Straits of Malacca were the scene of daily piracies, and all trade by means of native craft was paralyzed. 


\section{CHAPTER VII}

THE MALAY: HIS CUSTOMS, PREJUDICES, ARTS, LANGUAGE, AND LITERATURE

I

$\mathrm{T}$ will probably be most convenient to the reader if I now tell him something of the people whose country I have tried in general terms to describe. The Malay being to the Malay of the Peninsula, of Pêrak, or Păhang, or any of the States that were independent in 1873 , and it is to the latter that I propose to refer.

When Sir Harry Ord left the Straits to make way for his successor, Sir Andrew Clarke, there was not in existence, so far as I am aware, any published account of the people of the Peninsula; certainly no one in the neighbourhood was then in a position to give one, and what follows is the result of years of observation, made under circumstances of close intimacy with every class of Malay society. To acquire this information at first hand, it is necessary to speak, read, and write the language, to sympathize with the people-for without sympathy you cannot win the confidence of a shy and reserved race-to live in their houses, join in their festivities, be allowed to listen to their prayers, to attend the rites of marriage and of burial. The searcher after knowledge must journey with them by land, and river, and sea; he must take the field with them, join in their sports, listen to their gossip, their complaints, their stories, tend them in sickness, help them when in difficulty, share their sorrows and their joys, 
respect their prejudices, be kind to their superstitions, and always treat them with consideration. If he does this, and exercises a great patience, he will gain his end, and the end is worth the effort. Only he must be able to make or seize the opportunities without which he cannot reach the innermost heart of the people.

The Malay is a brown man, rather short of stature, thickset and strong, capable of great endurance. His features, as a rule, are open and pleasant: he smiles on the man who greets him as an equal. His hair is black, abundant, and straight. His nose is inclined to be rather flat and wide at the nostrils, his mouth to be large; the pupils of his eyes are dark and brilliant, while the whites have a bluish tinge; his cheek bones are usually rather marked, his chin square, and his teeth, in youth, exceedingly white. $\mathrm{He}$ is well and cleanly made, stands firmly on his feet, and is deft in the use of weapons, in the casting of a net, the handling of a paddle, and the management of a boat; as a rule, he is an expert swimmer and diver. His courage is as good as most men's, and there is about him an absence of servility, which is unusual in the East. On the other hand, he is inclined to swagger, especially with strangers.

His dress is a loose jacket, loose trousers, and a sârong -a kind of tartan skirt fastened round the waist and reaching to the knee. This garment has many uses: it serves as a bathing or a sleeping dress; fastened over one shoulder and under the other arm a man can carry all his luggage in it; slung on two sticks it forms a very good litter. On his head a Malay commonly wears a coloured kerchief, and he knows how to tie it so that it shall be becoming. All these articles of clothing are made of cotton, of silk, of a mixture of the two, or of silk and gold thread, according to the means of the wearer and the circumstances under which they are worn.

In I 874 practically all Malays went about bare-foot, 


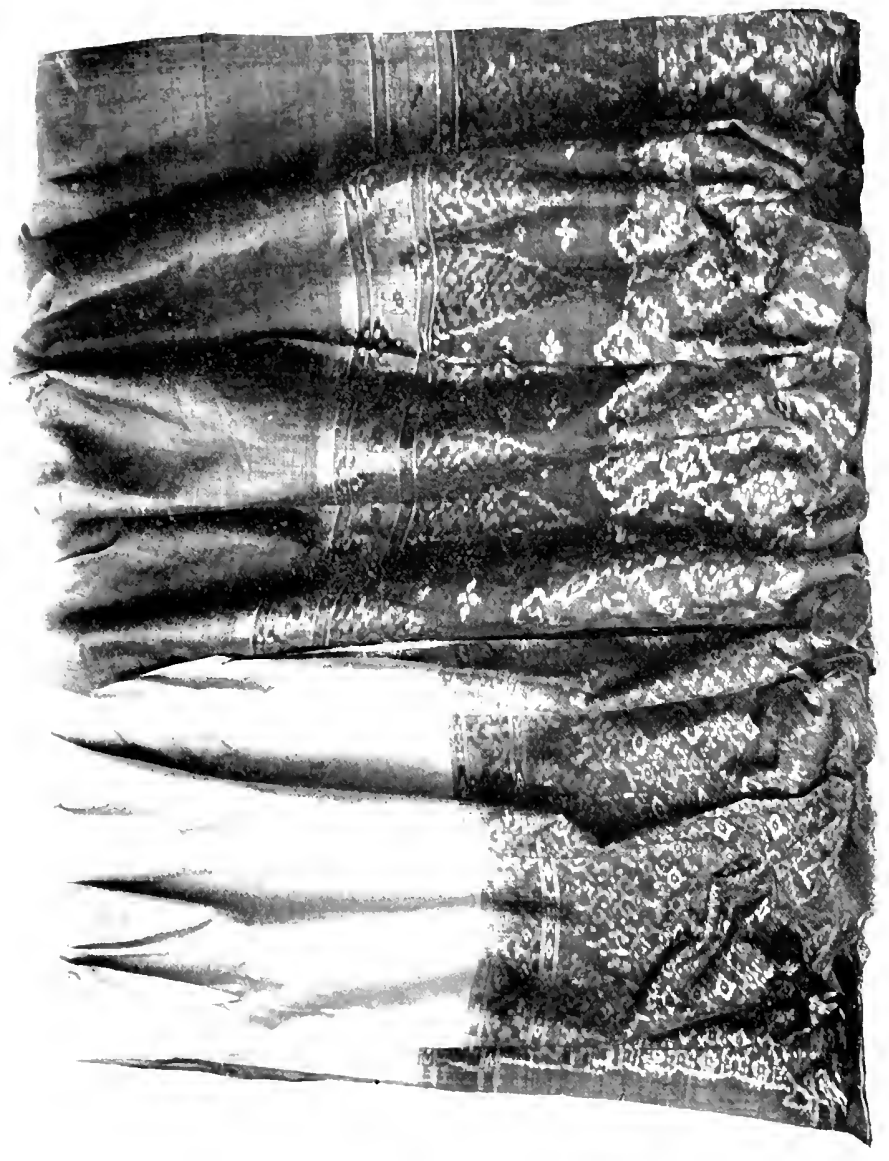

舀要

言

三人

$\bar{\equiv}$

二

二

三人

三人

$\div$

ㅍ

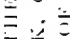

$=$

政

$\therefore=$

政

군

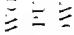

$\doteqdot$

1)

三人二

至

a

三

音

$;$

品

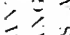

政

=

六三

至

三

品

政

- 

for shoes were useless in a roadless country. Nowadays they display a pretty taste in brown, or black, or patent leather, while the humble wear white canvas shoes, or a native pattern of sandal. In 1874 every Malay had as many weapons as he could carry: say, two daggers in his belt, two spears in his hand, a gun over his shoulder, and a long sword under his arm. The boys were usually content with two or three weapons. Now, the men carry umbrellas, and the boys slates and books.

The umbrella, especially if made of yellow silk or cotton, is used as a royal emblem, and it is probable that both the umbrella and the idea that yellow is the royal colour were imported from China. According to Malay history, at least two Malay Sultans married Chinese princesses. In some of the States of the Peninsula and of Sumatra both black and white are royal colours.

The Malay child wears no clothes and does as it pleases. When the parents are well-to-do there are always several people running about to attend to the child's wishes. I never saw a Malay child slapped, and they never seem to cry unless they are ill. They eat when they are hungry, and sleep when they feel inclined. The useful sârong, slung between two posts of a room, makes an excellent cradle or hammock. From about eight or ten years of age the boy is taught to read and write, and learns the Korân. Of course he cannot understand the Korân, because it is in Arabic; but if he is a child of the upper class he has to read it through, and it will save his face and delight the ears and hearts of his parents if he can accept the challenge to take his turn when the book is read in the house after the first evening prayer.

Once out of the thraldom of the guru, the teacher, the boy of 1874 ran wild and did a deal of mischief, much of which was regarded as a proper exhibition of spirit. If the son of a poor man, he had then to work-to help his father plant rice, fish in the river, tend goats, or collect 
jungle produce. The young Rajas and other gilded youths took to top-spinning, cock-fighting, gambling, opium-smoking love-making, and some of them to robbery, quarrelling, and murder.

A course of that kind of life might end abruptly, but more frequently it lasted long enough to induce a certain ennui as regards some of the pursuits. Marriage was inevitable, and was always supposed to make for reformation, but the reform was seldom more than transitory. Then there would perhaps come some kind of office, which, of course, meant an opportunity for licensed oppression, and, if that proved lucrative, the man with advancing years would develop into a miser, with some simple and inexpensive vice like the smoking of opium.

The leading characteristic of the Malay of every class is a disinclination to work. Nature has done so much for him that he is never really cold and never starves. He must have rice, but the smallest exertion will give it to him; and if he will not grow it, he can buy it for very little. Land had no value in the Malay States in 1874, and it was the custom for any one to settle where he pleased on unoccupied and unclaimed land, and leave it when he felt inclined. As a rule there would be a family cottage on a bit of land planted with palms and fruit trees, with an acre or two of rice land hard by. When the men of the family grew up and married, they would each in turn establish themselves near or far, while the old people and the girls remained in the original house till all the children were married or the parents died, or, more commonly, brought up grandchildren to inherit the usufruct of the land and occupy the house. No one was ever turned off the land, because it had no value, but sometimes a chief would lay claim to a productive orchard or a nicely-placed rice field, and the poor would find it impossible to resist the claim. All internal taxation was irregular, and the land was practically free. No culti- 


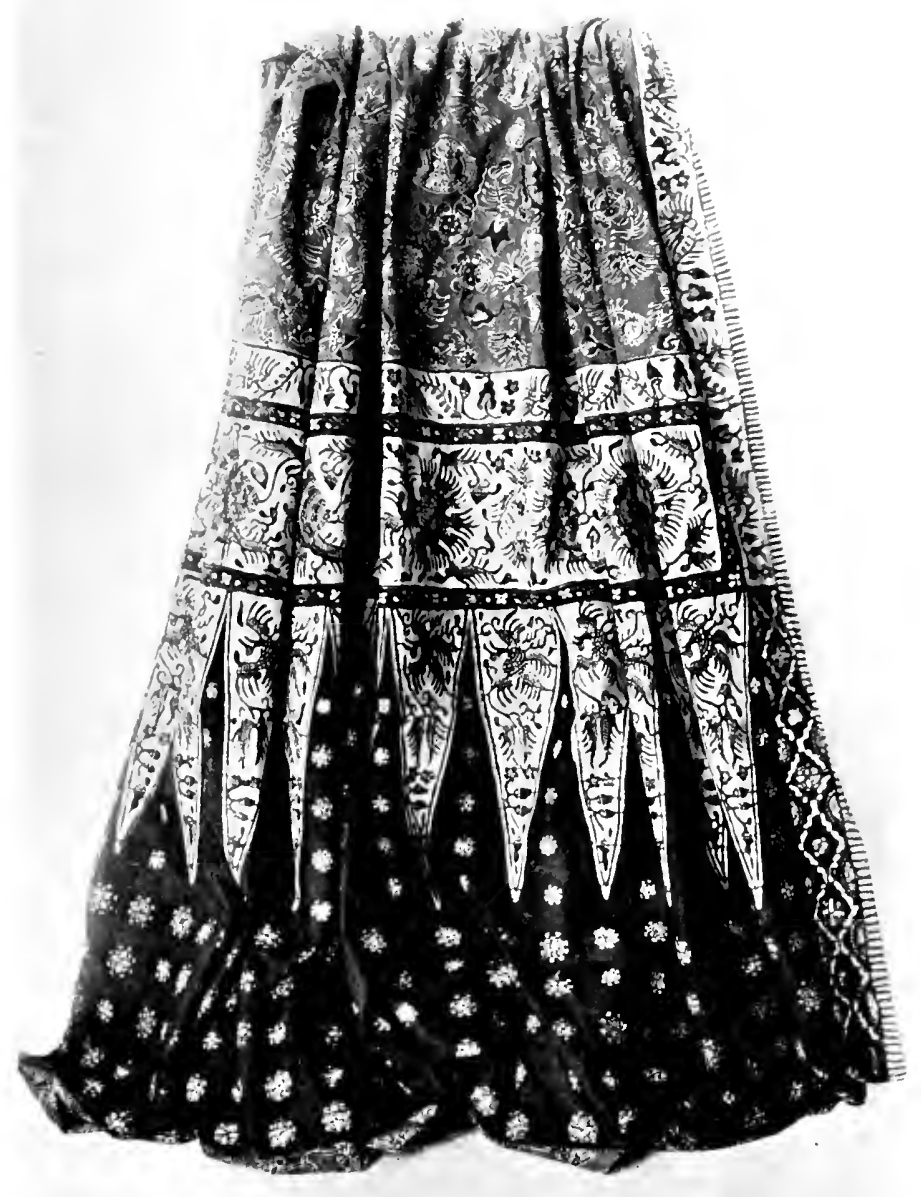

A SARONG BÁTEK OF DYED COTTON MAIE IN JAVA THE PREVAIIING COLOUR OF TIE BOHY IS BIUE, OF THE BORIERS ANI) CENTRE-IIECE BISTRE ANI WIITE 

vator had any title, but chiefs of districts and others with official positions-some, indeed, without-possessed written documents investing them with extraordinary powers over large and ill-defined areas. These documents were granted by the Sultan, but it was well recognized that they could be revoked or confirmed by his successor. It was, however, an accepted custom of the country that certain high offices, such as those held by the four and the eight chiefs in Pêrak, carried with them control over districts, or divisions of districts, and within those areas the chief claimed and exercised the powers of a landlord.

Less than one month's fitful exertion in twelve, a fish basket in the river or in a swamp, an hour with a casting net in the evening, would supply a man with food. A little more than this and he would have something to sell. Probably that accounts for the Malay's inherent laziness; that and a climate which inclines the body to ease and rest, the mind to dreamy contemplation rather than to strenuous and persistent toil. It is, however, extremely probable that the Malay's disinclination to exert himself is also due to the fact that, in the course of many generations, many hundreds of years, he has learned that when he did set his mind and his body moving, and so acquired money or valuables, these possessions immediately attracted the attention of those who felt that they could make a better use of them than the owner. The Malay is a philosopher and a fatalist, and he would reason that, if the world is made like that, it is useless to kick against the pricks. The practical lesson conveyed to him was that when a Chinese passed that way, it would only be thoughtful to relieve the infidel of anything of value which he might have about him, and if the man with the pigtail resisted-well, that was on his own head.

Whilst the Malay has no stomach for really hard and continuous work, either of the brain or the hands, if you 
let him take his own time he can produce most beautiful and artistic things. Perhaps I ought to say he has produced, for, except in very rare instances, he does it no longer; but I am convinced that if he were given the conditions which appeal to him, he would rise again to the height of his past achievements. Working in the precious metals, in gold and silver, in a mixed metal of gold and copper called suasa, and in a combination of silver, gold, and enamel, Malays have made vessels and ornaments and jewellery as beautiful in form, as original in design, and almost as perfect in workmanship, as anything of a similar kind to be found in the East. All this work was done under conditions which no longer prevail in the western States; it was done under a feudal system, where the workman and his family lived under the protection and at the expense of his chief, with no anxiety as to his own needs, and no pressure to hurry on the work. He was supplied with the metals, the tools, everything he wanted, and a capable worker was held in high esteem. In the courtyards of successive Sultans and chiefs, the goldsmiths, the blacksmiths, and the carvers in wood and ivory produced exquisite specimens of their various handicrafts, and some of these may still be seen. In silver they made beautiful bowls and dishes in every size, boxes of quaint shape and attractive decoration, and vessels of every kind in use by the people. In gold there were gem-studded boxes to carry the folded sîreh, scent-bottles which suggest early Greek work, chains and earrings, combs and brooches, hairpins, pillow ends, belt buckles, and the handles and sheaths of daggers. The most original and artistic work of all is called chitam or jâdam, and it was made originally in the Province of Ligor, which was conquered and absorbed by the Siamese many years ago. This chitam consists of a silver vessel on which a conventional pattern is hammered; a thin sheet of gold is then overlaid and hammered into the pattern 


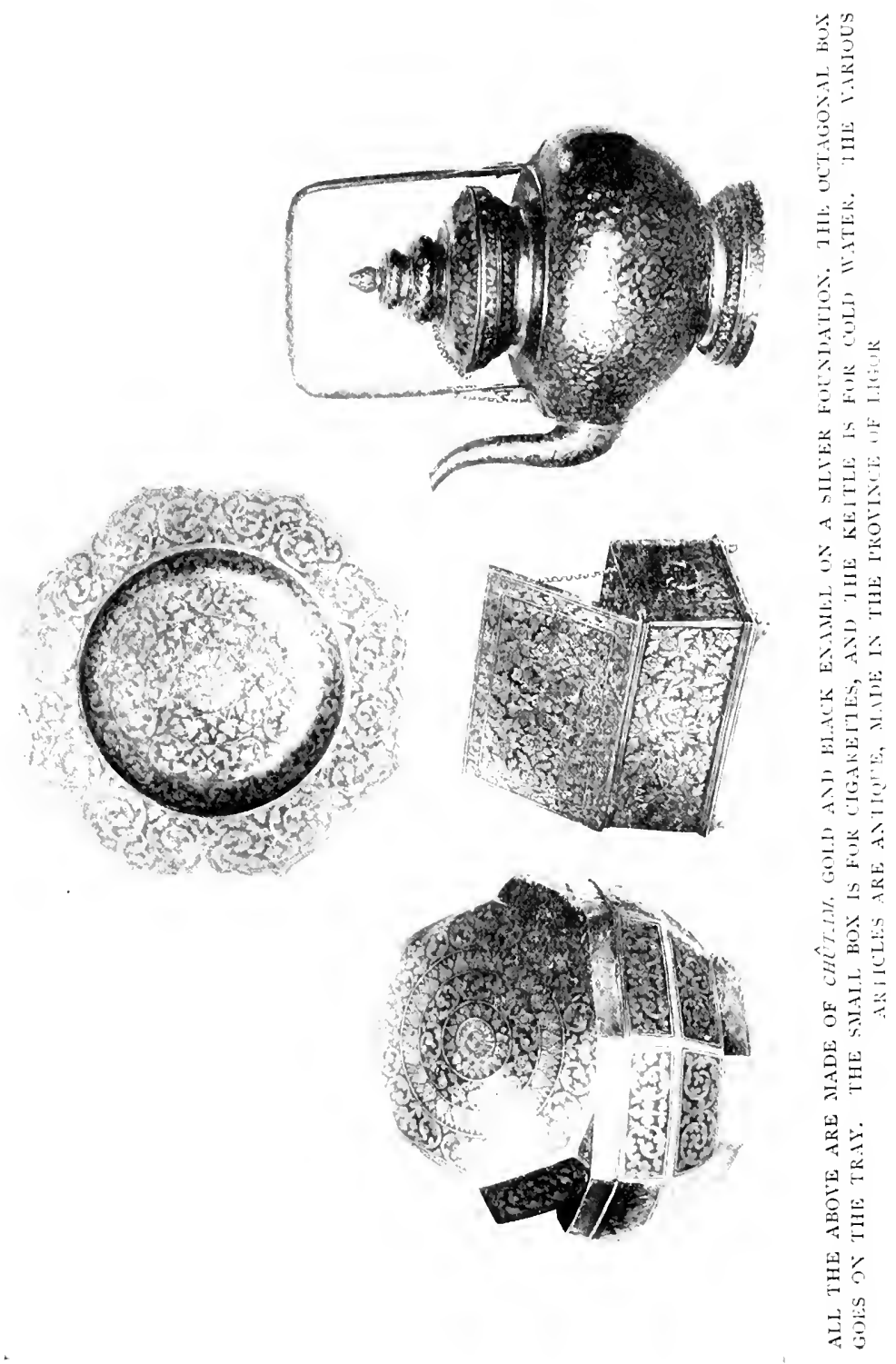





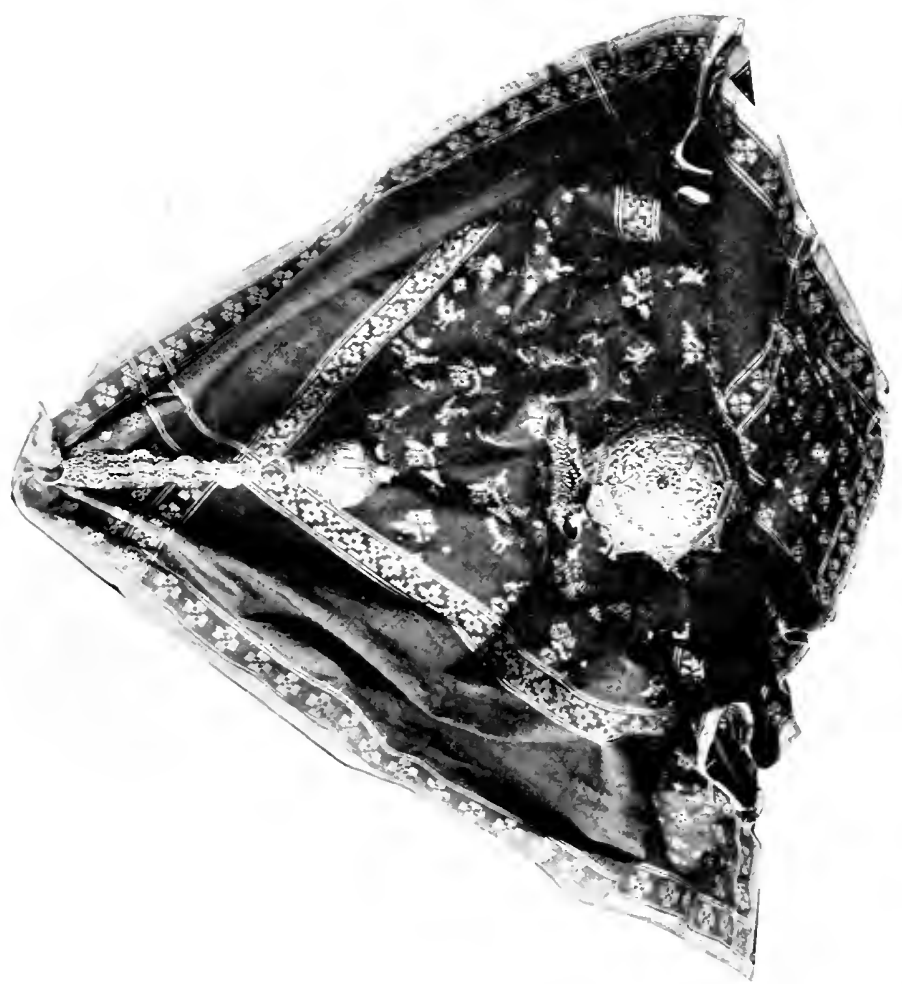

示示

s.

-

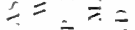

$=\div$

空

亲示.

$\checkmark=$

空

兴二

兰三标

-

$\leq=$

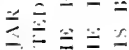

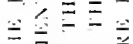

$\equiv \equiv$

,

二产等

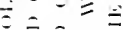

$\Xi$

=

管三

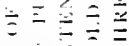

는

的

我三

$\equiv \leq-$

$5 \dot{0}=$

言突

兴

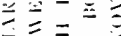

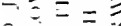

示标

$\bar{\Xi}$

-

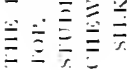



The depressions are filled with black enamel, the surface is polished, and a pattern is engraved with a sharp tool on that part of the gold which is exposed. Sometimes the gold is omitted altogether, and the product then resembles niello. The hinges and fastenings of the metal boxes are often both ingenious and decorative, and no two pieces of Malay metal work are ever exactly alike. The Malay silversmith appears to have carried on his trade throughout the Malay Peninsula, the Archipelago, and in Java and Sumatra. A little is still done in Trĕnggânu, in Păhang, and in some of the islands under Dutch control.

The smiths were notably makers of spears, krises, all sorts of daggers, a very well-balanced and highly-tempered chopper of various patterns, spurs for fighting cocks, and a curious kind of scissor used for slicing the betel nut. All these were made in Pêrak, and some of them in most of the other States. Celebes, Sambaua, Java, Palembang, Achin, Pětâni, Rĕmbau, and Trĕnggânu were all noted for the manufacture of spears and daggers, while the best choppers were made in Pêrak and Kĕdah. Some of the wood-carving is excellent, and the best now found in the Peninsula is done in the Nine States, where it was, no doubt, introduced from Sumatra. In Pêrak, as well as in Păhang and the other East Coast States, the Malays make rough, unglazed pottery of good shapes, ornamented with conventional patterns cut into the clay before it is fired.

Whatever the cause, the Malay of the Peninsula was, and is, unquestionably opposed to steady continuous work. And yet, if you can only give him an interest in the job, he will perform prodigies; he will strive, and endure, and be cheerful and courageous with the best. Take him on the war-path or any kind of chase, or even on some prosaic expedition which involves travel by river, or sea, or jungle, something therefore which has a risk; 
then the Malay is thoroughly awake, and you will wish for no better servant, no more pleasant or cheery companion. Perhaps it is these qualities which, a hundred years ago, made him such a dreaded pirate, a life to which he was driven by the unpardonable proceedings of early European navigators and adventurers, especially the Portuguese and the Dutch.

The Malay is loyal, for loyalty is part of his creed. $\mathrm{He}$ is hospitable, generous, extravagant, a gambler, a coxcomb. $\mathrm{He}$ is of fair and quick intelligence, a ready imitator, good at most games and likes to excel, but more inclined to admire the greater skill of a rival than to be jealous of it. $\mathrm{He}$ is reserved with strangers, cordial and sympathetic to his friends; he has a strong sense of humour, and makes an excellent companion, equally ready to talk or be silent. As a casual acquaintance he is politely uncommunicative; he will ask a few questions: but seldom give direct answers. Once you have gained his confidence he will probably make no concealments, taking a pleasure in telling you all he can. If he knows you well, he will be almost sure to borrow money from you, and he will seldom find it possible to repay the debt; but he will hold himself ready to undertake any service on your behalf, and you will probably realize in time that the obligation is rather on your side.

Privacy, as we understand it, is unknown in Malaya; therefore, secrets which mean life and death and dishonour are never confined to one or two people; but it is to the credit of the race that the stranger will find it almost impossible to get from the poorest any information which they believe they are bound in loyalty not to disclose. That is a highly honoured tradition on which their Rajas and chiefs rely with great confidence. The raiat will only speak when his Raja, or some one whom he regards in the same light, tells him to do so.

As a race Malays are guided more by their hearts than 


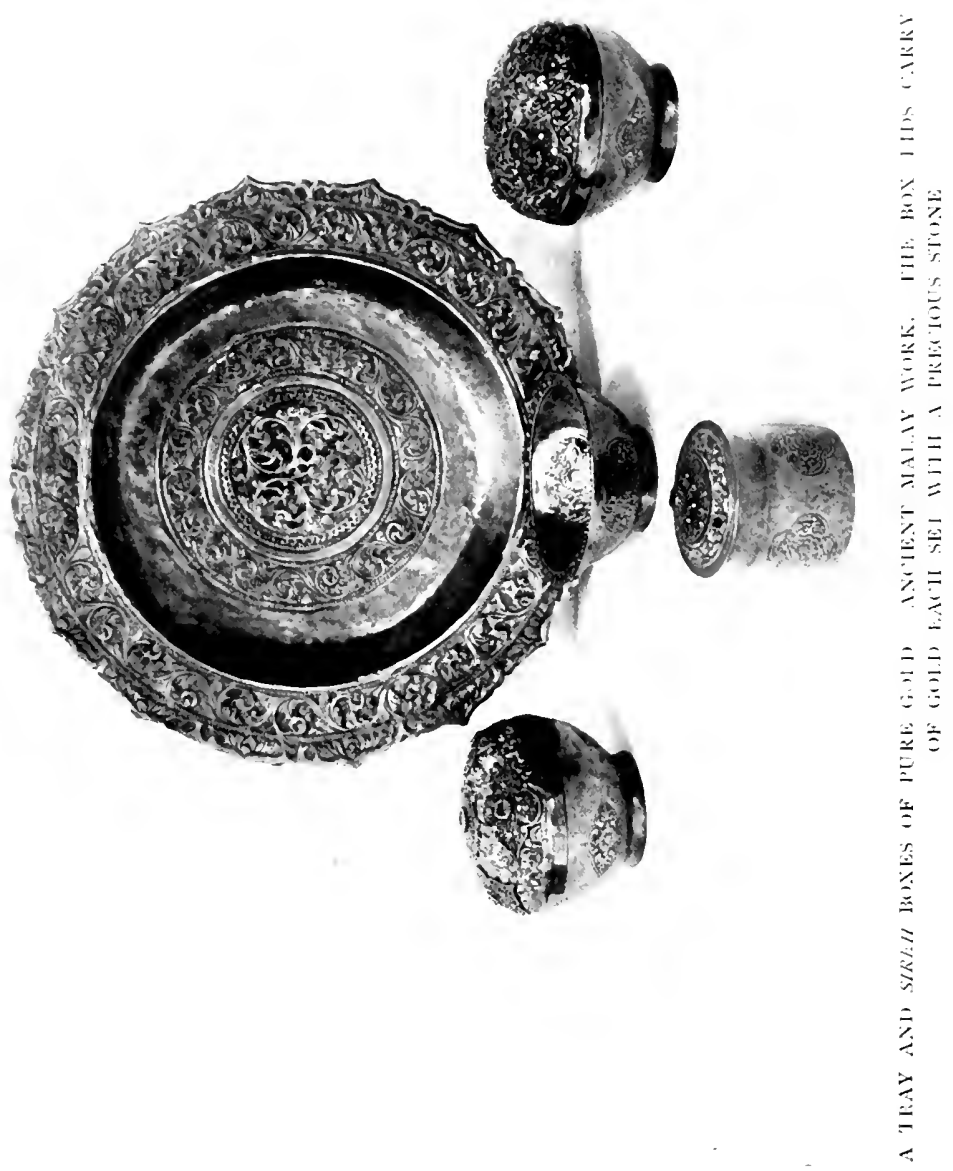



their heads. They will accept advice, follow a man to death, or go there at his bidding, not because he convinces them that it is the more excellent way, but simply because they like him. They will do the behest of a Raja or a chief because that also is part of the tradition of loyalty, the injunction of the men of old time; the responsibility is his, but they are willing to obey him blindly, expecting that he will support them in the day of trouble, and prepared to suffer if that be necessary. To do otherwise would be drahka, treason, and the punishment for that crime is death and disgrace.

There was, in 1874, a very broad line indeed between the ruling classes in Malaya and the raiats, the people. The people had no initiative whatever; they were there to do what their chiefs told them-no more, no less. They never thought whether anything was right or wrong, advantageous to them personally or otherwise; it was simply, "What is the Raja's order?" Wherever the Raja was recognized his order ran; the only exception would be where some local chief defied or disputed the authority of the Raja and told the people that they were only to take orders from him. Such a case would happen but seldom.

By nature and education the Malay is singularly conservative, and thirty years ago he held to customs and traditions with many of which Europeans could not easily sympathize. There was the practice of debt-slavery, a custom loathed by those who had to bear the burden of this iniquitous bondage, but upheld as a cherished privilege by the class which was benefited. And here it is necessary to emphasize the width and depth of the gulf which divided the governing from the working classes. The terms do not well fit the conditions of Malay society, for some of those who owned debt slaves did not pretend to authority in the affairs of the State, and from a European standpoint there were but few Malay labourers. At the time of which I am now writing there was not a wealthy 
Malay in the western States, for the Mantri, of Pêrak, who once had money, had spent it all in vain efforts to overcome the Si Kuans, and he was deeply indebted to Pinang Chinese, from whom he had borrowed funds to meet his necessities. But Pêrak was full of anak Raja, men and women, boys and girls, who bore the title of Raja, by direct descent from an ancestor of Raja birth. All these people claimed that the State must provide for them, and that claim was generally recognized. As there was no Civil List, no Treasury, no regular collection of revenue, and, above all, no accounting for what was raised in the name of taxation, the members of this Raja class endeavoured to satisfy their wants either by the holding of some office which enabled them to impose taxation on the people of a district, a village, a river; or they were given the right of collecting a particular tax in a particular place; or they were granted a block of mining land, and they arranged with Chinese and Malay miners for a certain percentage of all the tin and gold which came out of it ; or they were given authority over a tract of territory, and squeezed as much as they could out of those who inhabited it. Rajas holding high office usually maintained scores of relatives and hangers-on who, in return for this support, held themselves at the disposal of the master for any service he chose to command. It was the same with the chiefs, their families, and their retainers, and as no one had a hired servant or ever paid wages, it followed that all menial work was done by debt slaves and by a very few real slaves, either aborigines caught for that purpose or Africans who had been purchased. The Muhammadan law does not recognize that a Muhammadan can be a slave, though there was, practically, no difference between slavery and debt-slavery. It had, therefore, come to be recognized that it was the right of Rajas and chiefs to order and the duty of the people to obey. This rule had a practical observance whenever the Sultan, or any Raja 


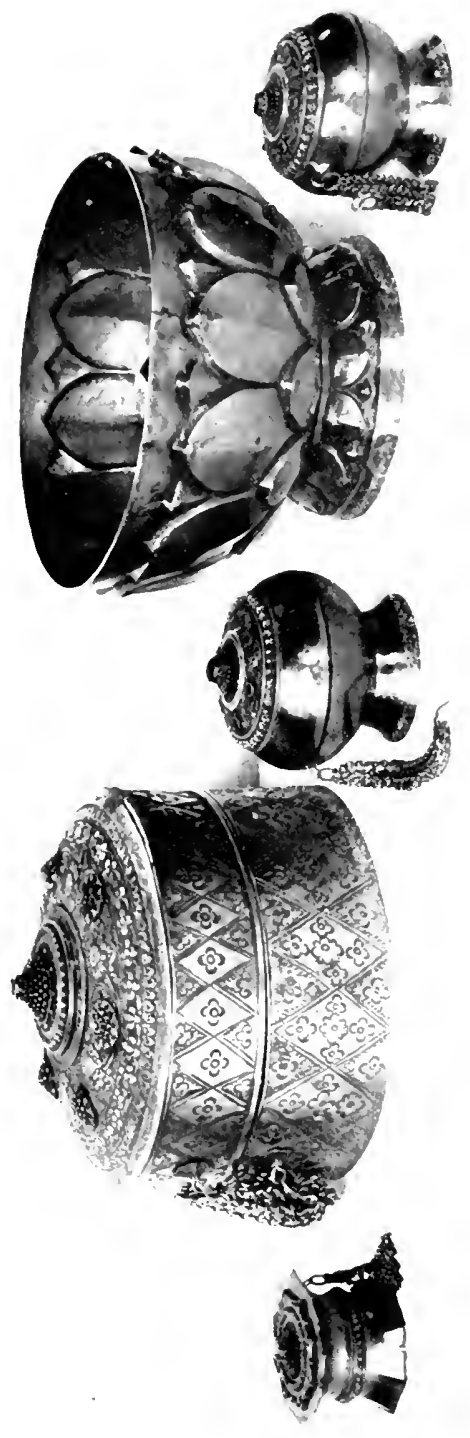

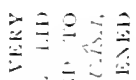

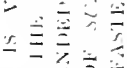

$\therefore$.

要要

禁等

$\vdots$

$\vdots \dot{\vdots} \div$

管

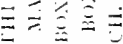

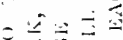

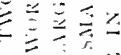

$=-y$

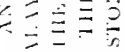

二

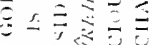

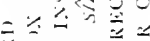

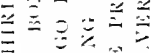

을

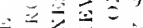

象芯三心

$\therefore-\dot{2}=0$

$\overline{2}=2=$

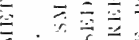

$\because \div$

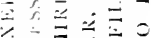

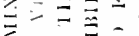

$+\overrightarrow{3}$

$\therefore=$

定

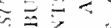

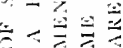

-

谷恣自

政

$\because=3$

$5 \equiv$

这

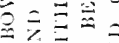

证自

象云

马皮

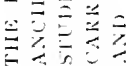



or chief of sufficient authority, wanted labour for any public or private work-such as the clearing of a river, the building of a mosque or house, the manning of boats for a journey-for then all the men within reach were summoned, through the village head-men, to come and undertake this forced labour, for which no payment was ever made, and though the labourers were supposed to be fed as long as the work lasted, that was not always done.

It might be imagined that, under these circumstances, the Malay would welcome any change, but strange to say that was not the case, and centuries of Malay mis-government has produced a race which looked with suspicion upon every innovation, opposed it on principle, and only became reconciled to alteration when the feeblest intelligence was compelled to admit that there was no harm in it. Indeed, some voluntarily contracted debts when they knew perfectly that it would lead to bondage; and when the whole system of debt-slavery was abolished, a certain number of the manumitted received the news of their freedom with regret, and hardly knew what to do with their new-found liberty.

It may seem curious that, living under such conditions, the ordinary Malay man should be extraordinarily sensitive in regard to any real or fancied affront, and yet that was, and is, characteristic of the people. I have already discussed this frame of mind, at some length, in another book, ${ }^{1}$ and will only say here that, when the Malay feels that a slight or insult has been put upon him which, for any reason, he cannot resent, he broods over his trouble till, in a fit of madness, he suddenly seizes a weapon and strikes out blindly at every one he sees-man, woman, or childoften beginning with those of his own family. This is the amok, the furious attack in which the madman hopes to find death and an end to his intolerable feeling of injury and dishonour. There can be little doubt that, except 
in rare instances, those who are suddenly seized by this fury to destroy are homicidal maniacs, and a straw in the current of life gives the suggestion which alone was needed to impel them on their career of destruction.

The Malay has been a Muhammadan since the reign of Sultan Muhammad Shah of Malacca, who flourished in 1276, and made his kingdom the third greatest in the Archipelago-Majapahit, in Java, being the first, and Pasi, in Sumatra, the second. It is unlikely that the Malay has ever been a religious bigot, it is not in his nature; and though he is a professing Muhammadan and ready to die for a faith which he only dimly understands, he has never entirely abandoned the superstitions of his earlier days. The origin of the Malay race is still a matter of doubt, but there are good reasons for believing that Malays are the descendants of people who crossed from the south of India to Sumatra, mixed with a people already inhabiting that island, and gradually spread themselves over the central and most fertile States_- Palembang, Jambi, Indragiri, Mĕnangkâbau, and Kampar. From Sumatra they gradually worked their way to Java, to Singapore and the Malay Peninsula, to Borneo, Celêbes, the other islands of the Archipelago, and even to the Philippines, Sulu, the Caroline Islands, and perhaps to Formosa. The word Malay is said to be derived from a river of that name, the Sungei Malâyu, which flows by the mountain Siguntang Mahâ Meru, in the State of Palembang, in Sumatra, but it is equally likely that it was carried by the first emigrants from the Mallia or Malaya country in Southern India. The Malay tradition, for which there is not only popular belief but the authority of the Malay Annals (whatever that is worth), is that the cradle of the Malay race is this Bukit Siguntang Mahâ Meru, now recognized as Gunong Dempo, and there appears to be there a stream with the name Sungei Malâyu. People coming from that place would naturally 


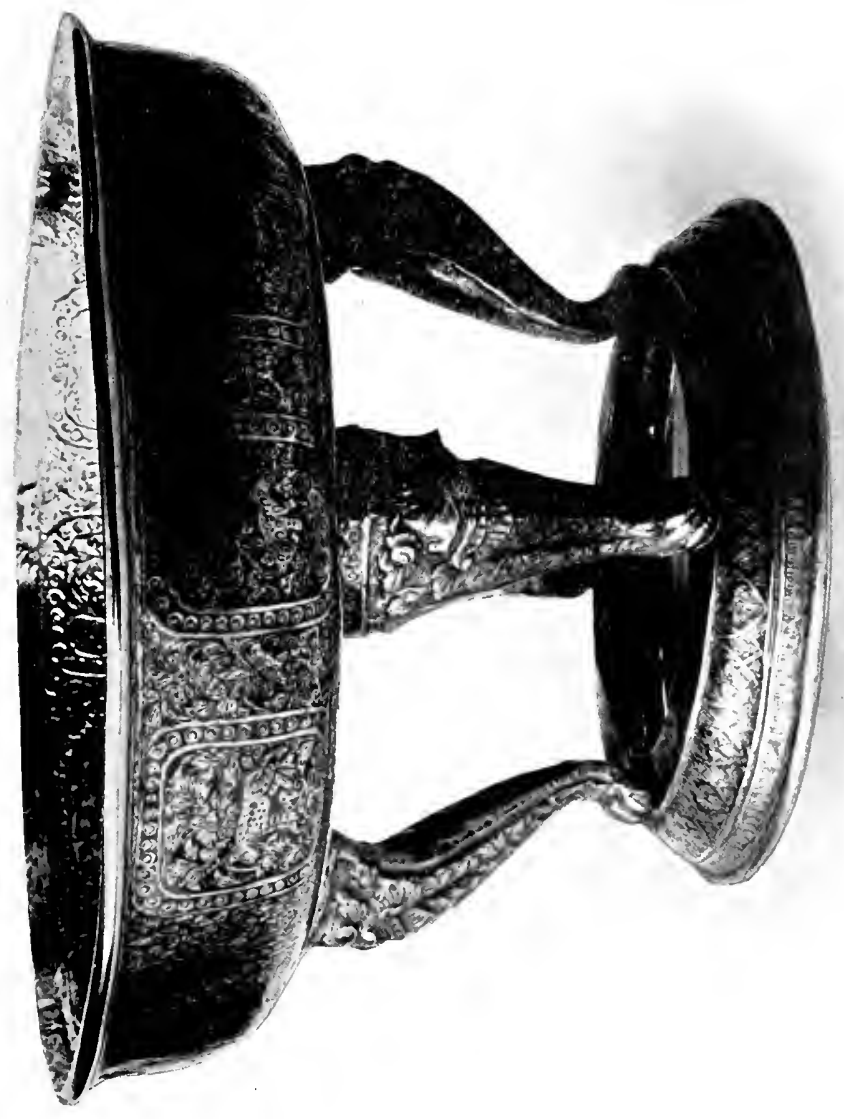

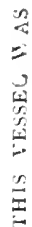

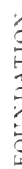

$\therefore 7$

的

ज为

4

它

$\stackrel{1}{2}$

元

応

壮

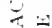

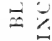

0

- 然

完

0

$\therefore 1$

政

范

㕸

量

3
3
3
3
0

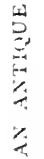



describe themselves as Orang Malâyu, the name by which they are known to-day. To support the theory of their Indian origin we have not only places like Singapura, with purely Indian names, but, when Pêrak Malays go back to their old superstitions and endeavour to propitiate malign spirits, they use a form of incantation which they do not understand, but which can certainly be traced to a Sanskrit origin.

I have said the Malay is a professing Muhammadan, his life is ruled by the Muhammadan law, and he accepts the teaching and the injunctions of the Moslem priesthood, but, with rare exceptions, he cannot be called devout; he does not pray five times a day, he does not rigorously observe a forty days' fast, he is not a regular attendant at the mosque. He is married and buried as a Muhammadan, he is circumcised and goes through the outward observances imposed by his Faith, yet, when he is hard pressed, he has a way of harking back to original sin, and the practice of witchcraft abhorred by the priesthood. This tendency to backsliding applies to all ranks of Malay society, from the highest to the lowest; but even when Malays take to devil-raising, to propitiating the spirits of earth and air and mountain, though many are implicit believers in the efficacy of the rites performed, some of the more intelligent enter into the game with extreme keenness, but with their tongues in their cheeks. If Malays are not inclined to work, neither are they greatly inclined to religious discipline or observance; still they are more tolerant than others whose lives are guided by a selection of higher moral principles.

Thirty years ago the Malay was not greatly impressed by the white man. Very few Malays of the Peninsula had ever seen any white men, and the popular impression was that they were people with loud voices, indifferent manners, and worse customs; that they habitually used bad language in their conversation, and not infrequently 
drank to intoxication. That impression has now been removed-to a large extent-but it is easy to understand that these failings were specially abhorrent to the Malay mind. His nature is to be reserved and severely polite, and he deeply resents a curiosity which leads Europeans into indiscretion. It is not the custom to ask a Malay his name; it is well to make the inquiry when he cannot hear it, but if you must know at once, you should ask some one else. Similarly you are not expected to express any curiosity you may feel about where he is going, or on what business, and it is specially advisable not to inquire after the health of his wife and daughters. It is a mistake to enthuse over the beauty or excellence of a Malay's possessions, for the Malay may feel it incumbent on him to ask you to accept what you so greatly admire. If that happens, the European should firmly but politely refuse the proffered gift, remembering that it is not a spontaneous act, but the result of his own too pointed remarks. If a Malay is wearing a weapon, it is not the custom to ask to be allowed to look at it, and if this imprudence is committed and the owner hands you the kris, or whatever it is, you must not unsheath it without first asking for permission to do so, and then you must draw the blade very slowly indeed and sheath it in the same way. Thirty years ago a Malay never moved without his kris, when he bathed he took it with him and when he slept it lay by his hand. He gave it more attention than his wife, and probably put a higher value upon it. If it was a famous blade, of Bugis make, and perfect in all measurements and every other test, no money would buy it; a common saying was, "money will buy gold, but it will not buy a lucky kris." The owner of the "lucky" dagger was supposed to get home on his adversary before the latter could touch him. Therefore for a stranger to try the point of the weapon on the wall, or the floor, was a grave insult to the owner. If it is urged that all these injunctions are 


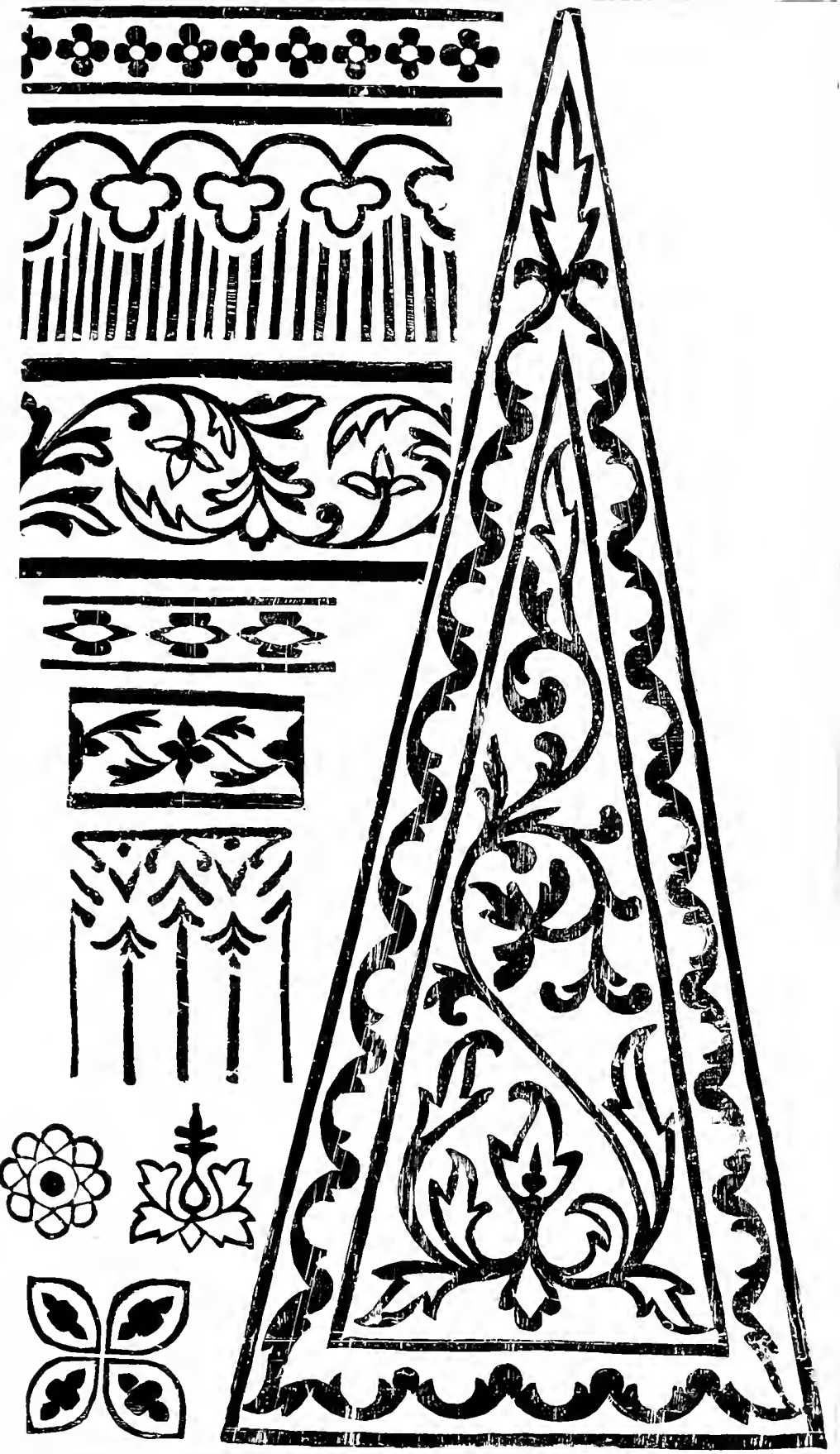



needless, and would naturally suggest themselves to persons with any pretence to good manners, I can only say that there are a number of people in the world who never get beyond the pretence, and I have seen Europeans, of whom you would not expect it, do all the things here mentioned as being serious offences to a Malay. He thinks that the white man's dress is very indelicate, but he will not tell him so, though the white man will, without hesitation, say, "Why do you wear this, or that?" The dancing of white people is also inexplicable to the Malay, and unless he is prepared to bring his own ladies it is wiser not to invite him to that form of entertainment.

Though the Malay is hardly ever a bigot in matters of religion, he has the strongest possible objection to a Malay woman marrying or living with a Chinese, and this is another of those matters which have caused a great deal of trouble in the Protected Malay States. A fairly well-to-do Chinese, a small shopkeeper for instance, appears to make a satisfactory husband, and it has happened that Malay women have preferred life with the Chinese infidel to a harder lot with a man of their own race and faith. The common result was, first a warning to the woman to leave the man of her choice, and if that failed the Chinese was killed, and sometimes the woman also. If the Chinese chose to become a Muhammadan these primitive measures would not be resorted to, but there was, and there is, a violent objection on the part of the Malay community to these domestic arrangements between the Celestial and the Malay woman. Of course no one was greatly shocked if a Malay man gathered a Chinese woman into his household, but the practice, seldom resorted to, was never regarded with favour.

The attitude of the Malay towards his women was not that which is observed in most Muhammadan countries. Married women seem to have always been allowed a very considerable liberty, and the man who tried to exclude his 
womenfolk from such amusements and social intercourse as was open to them was regarded as a jealous curmudgeon, and whatever happened to him the sympathies of society were with the ladies of the house and not with the master. On all festal occasions-a wedding, earpiercing, the appointment of officers by the Sultan, and so on-it is the invariable practice to give great entertainments to large numbers of people. At these times those who are invited are expected to bring their wives, and often their daughters or other near relatives as well. All these ladies lend a hand in making the necessary preparations for a series of festivities, which may last from one or two days to several weeks, and it is they who organize, direct, and actually assist in all the cooking, which is the main feature of the entertainment.

The guests who come from a distance are accommodated in the house of the host, or of any of their own friends in the neighbourhood, and it is usual to give them a meal which would correspond to luncheon-some time between twelve and one o'clock-and a dinner as soon as it is dark -that is, about seven o'clock. The evening meal is the one of real importance. When it is ready, the host and his principal guests sit in a circle on the floor, on mats spread for the purpose, and a great variety of dishes of food are placed in front of them, within easy reach of every one. They are waited upon by girls who either belong to the house or have come in to help, and who are dressed in a sort of uniform, and in the house of the Sultan they carry a strip of embroidered yellow cloth on their right shoulders. As soon as the diners have taken their places vessels of water are handed round, and every one washes his right hand-that is, the hand with which he eats. Then great bowls of boiled rice are served, from which the guests help themselves with a spoon made of wood, or of the shell of the cocoanut. For the rest, each man helps himself from the dishes in front of him, and 
when all are satisfied the servants bring a course of sweets-things that are half cake, half pudding or jelly, very sweet and rather insipid. After that there is tea or coffee, another washing of hands, and then cigarettes. In old days the sireh box used to be passed round immediately after the meal, and all the older guests indulged in the delights of this astringent. Now the chewing of betel has gone so completely out of fashion that it is seldom seen. Sireh is the leaf of a vine on which a little lime is spread with the finger, a scrap of betel nut and a bit of gambir are then wrapped up in the leaf, and the packet put in the mouth and chewed.

Whilst the host and his friends were being served in a special corner of the room, usually on a higher level, numbers of men of lower degree would sit side by side all round the walls, and the servants would attend to their wants in exactly the same way as to those at the higher floor. Very shortly after the meal was over the guests would leave the house and visit all the various entertainments prepared for their amusement. These would usually consist of Malay theatrical performances, shadow plays, chess, or gambling in one form or another.

As soon as the men have finished, the women take their meal; but that is always behind the veil, in the women's apartments. When poor people are quite alone, the man of the house, his wife and children eat together, but in the case of Rajas and well-to-do people the master very seldom eats with the ladies of his family.

When there is no great gathering for a State function, or a ceremony, such as the wedding of the son or daughter of an important person, the Malay still does a great deal of quiet hospitality. Either he entertains his own friends who are visiting or passing that way, or some stranger comes with an introduction or recommendation which practically makes the offer of hospitality a necessity. Amongst those who know each other well it often happens 
that no invitation is given in so many words; the visitor is there, and, when a meal is served, he shares it as a matter of course. It is on such occasions that the privileged friend sees the real inner life of a Malay family; for after dinner his host will invite him behind the curtain, where he will meet all the ladies of the household, and probably some of their relatives and friends as well.

Even in his most unregenerate days the Malay dearly loved a real picnic. He would go with a great party, on elephants, or by boat, to some charming spot in the depths of the jungle, a picturesque pool or waterfall on some clear mountain stream, and after a few hours of fishing, swimming, diving, rock-sliding or similar sports, fires would be made, rice cooked, fish roasted, and a most excellent meal improvised out of almost nothing, served on leaves of the wild plantain and eaten with fingers only. Here you would find men, women, and girls all mixing perfectly freely, and with very little pretence at shyness; but it is true that the party would include no real strangers. There is something strangely attractive and fascinating about the primeval forest, and even now it is probable that to Pêrak Malays of every class, especially those of the Sultan's own household, nothing would appeal more than four or five days' journey, in boats or on elephants, into some part of the country which is still practically unexplored. There is just such a place, full of the mysterious attraction of the unknown, straight inland from Pâsir Panjang on the left bank of the Pêrak River. It is called the Folding Plains.

If I give to the Malay woman a space which is all inadequate to her merits and influence on Malay society, it is not because I count her as a negligible quantity, but because, as a matter of history, she never had much to do with those affairs with which this book is mainly concerned. As a child she does not receive as much attention as a boy, but she is invested with the national garment, a tiny 


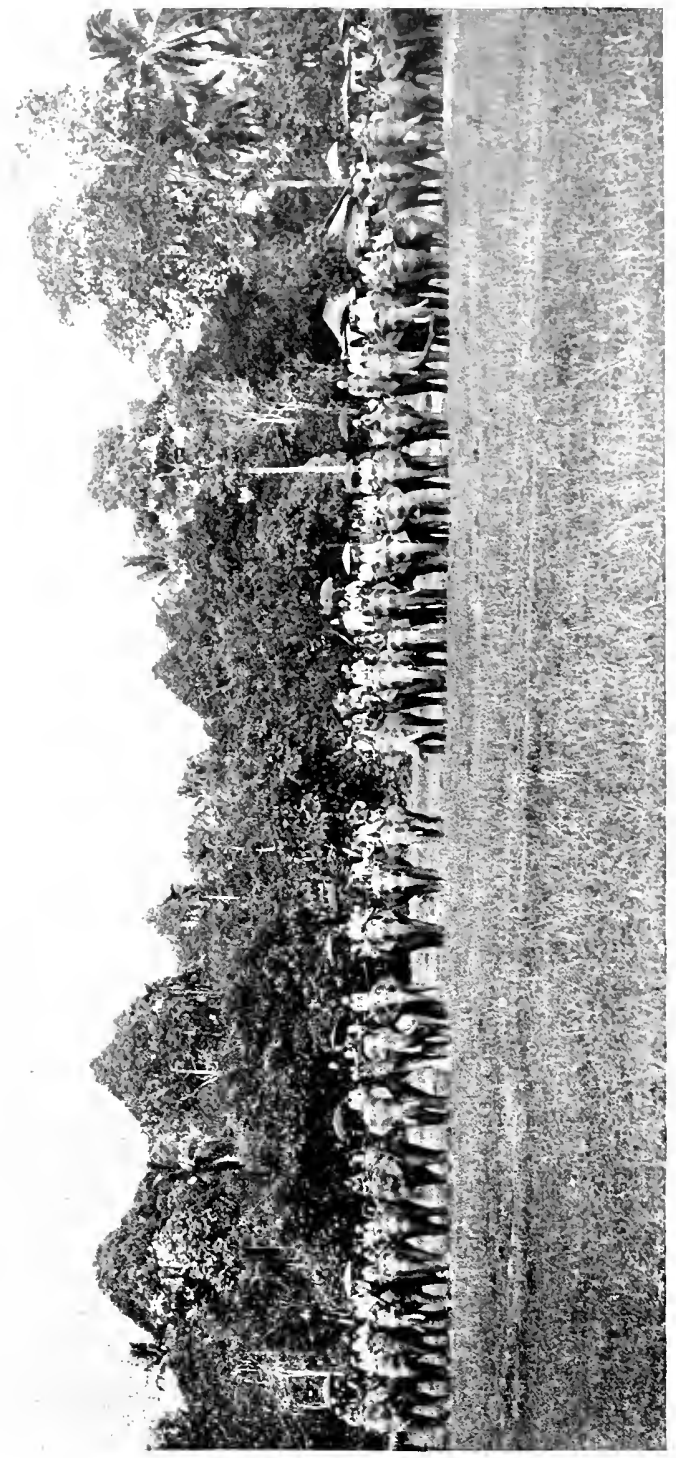

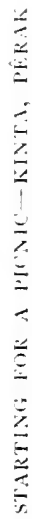



sârong, rather earlier than he is. Whilst the boy is learning to paddle a boat and help his father in any way he can, or is being taught the aliph-ba-ta (the Arabic alphabet) and the reading of the Korân, she is mostly in the house, helps her mother to carry water from the river, morning and evening, when all Malays bathe, and assists in the cooking, or any other household work. A Malay cottage is the embodiment of untidiness, and usually of dirt and insanitariness, but in this respect there has been a marked improvement of late years. The house is not cumbered by furniture or any attempt at decoration; there are no tables or chairs, no whitewash, and very little paint. The floor, which is always raised four or five feet above the ground, is of planks, nîbong, or split bamboos, and it is covered with mats; the walls are of plank or palm leaves, bark or interlaced cane; the thatch is of palm leaves. Every small Malay house is divided into three parts; a narrow veranda in front, and the rest of the floor space under the main roof, form the house; while, tacked on behind, is a small excrescence used as a kitchen. The same principle is carried out in more pretentious houses, only each of the three divisions is much larger and often forms a separate building, joined to the next one by a few feet of covered way. Strangers seldom pass beyond the veranda.

In some of the Malay States a great deal of weavingoften very beautiful-is done; there almost every house has a loom, and the main occupation of the women of all classes is the making of silk or cotton fabrics.. In Pêrak they pride themselves on their skill in mat-making and embroidery, and not without reason. In Kĕdah the women plait the inner fibre of the pandanus into baskets of a marvellous fineness, and they also weave a cloth of mixed silk and cotton. Sĕlangor was once famous for its sârongs of cloth of gold, but years of warfare destroyed the industry, and now they make nothing. In Păhang the women make excellent mats, of various colours, and very 
good silk cloth ; but the best and most beautiful weaving is done in Trĕnggânu, an independent State on the east coast, and in Kelantan, its northern neighbour.

The girls of poor people share all the women's tasks from an early age, and, in the season, they do most of the lighter work in the planting, the reaping, the winnowing, husking, and pounding of rice. Many of them find time to learn to read and write, and nowadays, in the Federated Malay States, there are successful schools for Malay girls. A girl sometimes, but very rarely, marries at fourteen ; but from seventeen to twenty is a much more common age. Until she marries she is not supposed to have any conversation with men, and when out of doors (never alone, of course) she meets a man she covers her face with extreme ostentation. Sometimes the effort is so great that her face is for a moment entirely disclosed. It is no doubt the result of excessive modesty and nervousness.

Malay girls are sometimes surprisingly fair for Easterns, but they vary from all shades of light to dark brown. Their hair is always black and usually abundant; their eyes are large and dark, their noses rather flat, mouths of moderate size but good shape, and teeth extremely white; they have good foreheads, round chins, and their faces are rather wide than oval. They nearly always have strongly marked eyebrows and long curling eyelashes. The general effect is that of a pleasant and good-humoured face, with plenty of character but no great claim to beauty. In height they are short, cleanly made and well formed, with smooth skin, very small hands, and small but square-toed feet. They admire small waists but use no appliances to produce them. As a rule they have pleasant voices and seldom raise them. In the house they wear a sârong and a loose jacket, long or short, but when dressed to be seen they often wear two sârongs, one over the other, and a long jacket of silk or satin, fastened in front by three gold or jewelled brooches. Their hair is pulled off 


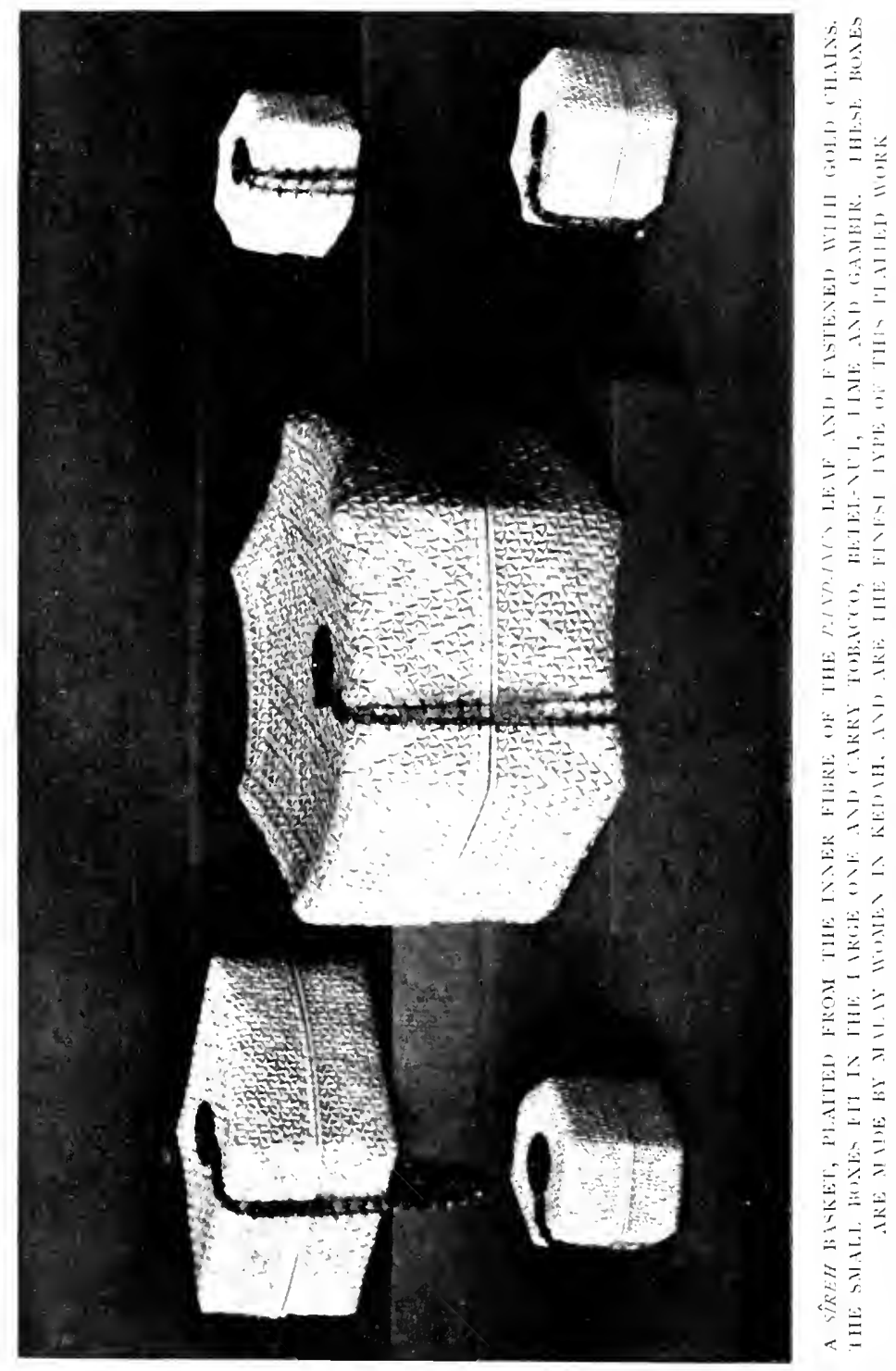



their foreheads and fastened in a knot behind with five or six jewelled pins. They are fond of rings, bracelets, and earrings, and not above the use of powder on their faces.

When the Malay States were entirely independent, it is probable that no girl was ever consulted as to her wishes in the matter of matrimony; everything was arranged by her parents and relatives, and indeed the young man was usually treated in the same way. Now it is rather different, and the most enlightened Malay parents would not press a girl to marry if she expressed a strong objection to the suitor. The wedding, especially in the case of the children of people of rank, is a very long, very tedious, and very expensive affair; all that need be said about it here is, that the wearing of orange blossoms and the throwing of rice are both Eastern customs and simply mean "be fruitful." The giving of wedding gifts, always money, is also a well-recognized custom amongst Malays. I have often known the Sultan of Pêrak-one of the most thoughtful of hosts-when he invited Europeans to witness the final and chiefest ceremony at the marriage of one of His Highness's children, provide his guests with the wedding gift lest they should be taken unawares.

With poor people it is usual for the bride to accompany her husband to his own home very shortly after the conclusion of the marriage ceremony; with Rajas and people of rank, the bridegroom often stays for months in the house of his wife's parents before they will let her go away. Not infrequently the husband goes and leaves his wife with her parents; he may even return several times, making long or short visits, before he can persuade the parents to part with their daughter. When at last she does leave her home it is possibly only for an absence of a few months, and for years she may spend almost as much of her time with her parents as with her husband. A Malay, like other Muhammadans, is allowed by law to have four wives at the same time, and, if he can afford it, 
he usually takes advantage of the permission. It nearly always happens that one of these ladies, of the same social rank as the husband, is the principal wife, and she remains, while the others, or some of them, are divorced and replaced. When a man embarks on the luxury, or extravagance, of more than one wife it is always understood that he is prepared to provide a separate house and establishment for each additional lady, and it is his duty to treat them all alike, to pass the same amount of time with each, and, if he makes a present to one, to give an identical present to each of the others. It need not be assumed that all Malays are scrupulous to act up to the letter of this law, but some of them do so. Divorce is certainly easy, but it is by no means the man who alone seeks it, and when the tie has been finally loosed, and the hundred days of grace, or abstinence, have expired, the woman is almost as certain to re-marry as the man, especially if she is young. Women of good birth and of means sometimes marry for the third or fourth or $n^{\text {th }}$ time, when they are between fifty and sixty years of age, but as a rule Malay ladies do not count on their physical attractions after they have reached the age of forty. I have often discussed the position of married women with the leaders of Malay society, and I have been struck by the fact that they have only one complaint to make, and that is their strong objection to being one wife of several. To divorce, as it obtains with them, they seem quite reconciled; but the idea of sharing a man with several other women is distinctly repugnant to them. Probably that opinion is very seldom expressed to a man, and never unless it is sought, but it is discussed by women.

Once a woman has married, and so obtained a certain amount of independence, she will, especially if she is of strong character, develop into a considerable power in her own household, and often exert her influence in many 


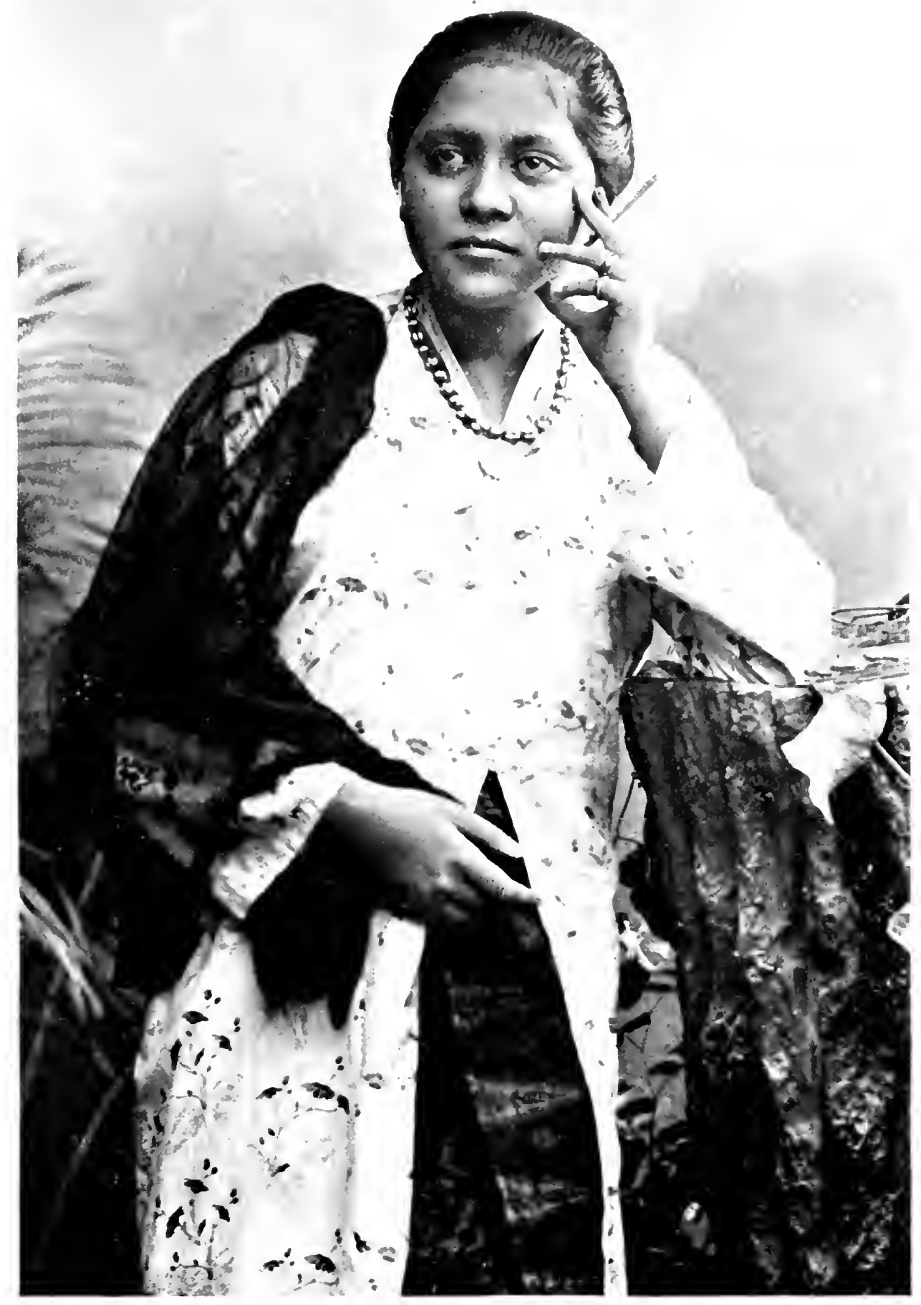

I MAIAY (IRI. 

directions beyond those narrow limits. She may earn a reputation as a good housewife, an excellent manager, a capital hostess, and even develop much business capacity. As the wife of an official she takes an interest in State affairs, and does her best to push her husband's claims to preferment and title; in this last ambition she has a special interest, for certain offices and titles held by the husband confer rank and title on his principal wife, and that helps greatly to assure her position. It is also the custom to grant offices, titles, and salaries to ladies connected with the Court, and in these cases, the husband, if there is one, is not concerned. Malay women of the better class, and most of those in the entourage of the Sultan and the leading Rajas, are distinctly intelligent if they cannot be called highly educated. They are usually of a cheerful temperament, capital company, witty and interesting, with a strong sense of humour; a man has to do his best to hold his own in their society. Both men and women are very quick and accurate in their estimate of strangers of any nationality, and especially of their social status. A Malay man hardly ever speaks of his food, either in anticipation of a meal or in criticism afterwards. Perhaps more curious is the fact that a Malay woman does not discuss another woman's clothes, either in praise or disparagement, but Malay men sometimes do it.

In illness Malays rely upon their own doctors, usually "wise women" with almost no real knowledge. Though the country is now supplied with many excellent hospitals, in the charge of able English surgeons, it is almost impossible to persuade Malays to enter them, except in cases which require surgical treatment. With great difficulty, and the assistance of a legal enactment, the people have been compelled to submit themselves to vaccination, with the result that smallpox, once the greatest scourge of the country, is now almost unknown. This is one of the innovations the value of which the Malay gratefully recog- 
nizes. Cases of deformity, imbecility, and hesitation of speech are very rare, and the Malay has an instinctive dislike to persons so afflicted. As already mentioned, when a patient becomes dangerously ill, and the usual forms of treatment have failed to give any relief, it is common, especially in Pêrak, to call in a pâwang, a kind of wizard or witch, who tries by incantations and other forms of the black art to lure the evil spirit from his prey.

For any one who has to do with Malays a knowledge of the language is an absolute necessity. To acquire such a smattering of the tongue as will enable a person to carry on a very simple conversation with the various Eastern people to be met with in the Straits Settlements and the Malay States is an easy task; but to speak, read, and write Malay really well is a matter of great difficulty, and the knowledge can only be obtained by years of study, and constant intercourse with the most cultivated Malays of the Peninsula. The Malays had several written characters of their own before they became Muhammadans. Since that date they have used the Arabic character and alphabet, with the addition of six letters, which were necessary to express sounds not known in the Arabic language. On the other hand, thirteen of the letters are only used in the writing of words of Arabic origin, leaving twenty letters for writing purely Malay words. As in all languages which use the Arabic character, Malay, is of course, written from right to left, and what greatly increases the difficulty of reading it is, that, to the unskilled eye, there appear to be no divisions between the words, no beginnings or ends of sentences, no commas, semicolons, or full stops, and the vowels are often not written at all. For instance, the common word minta, which means "to ask", is always written mnt; the compound word ka-pâda, which means "to" is written $k p d$ and the compound word sa-blas, meaning "eleven" is written sbls. Nothing but practice 


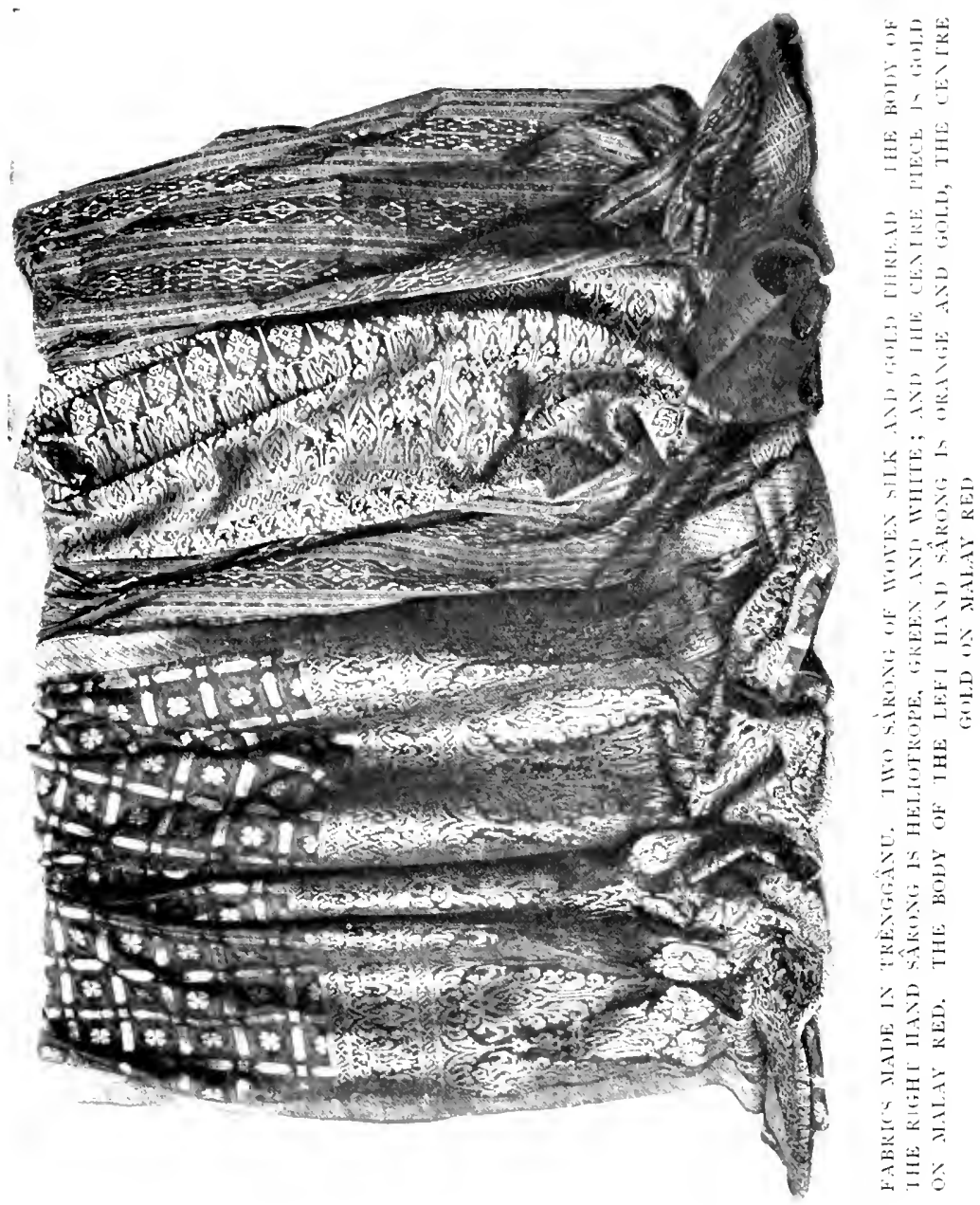



and the context will enable the reader to get over this difficulty and, when an unknown word is met with, the correct pronunciation can only be guessed, though a practised eye will probably divine the pronunciation without hesitation. The language is not burdened with much grammar and, for a long time, the study is mainly an effort of memory, to learn so many thousands of words and recognize them when met with in print and manuscript. All the real difficulties begin when ordinary conversation is no longer an effort. To speak Malay well, as Malays always talk to each other, is to speak in idioms which, as a rule, have no counterpart in European tongues. This, again, is an effort of memory and the result of constant practice. There is a step further. It is the delight of Malays, who recognize that they have made conversation a fine art, to talk in parables; to express what they mean by something which, to the uninitiated, would seem to have no connexion with the subject under discussion. The more difficult the riddle, the further the actual words from their implied meaning, the more subtle is the thrust and the more delighted the audience. If the less intelligent listeners find that something is going on which they cannot in the least understand, so that they smile vacantly as people do when they fancy something witty has been said in a foreign tongue, that only adds to the enjoyment of the rest of the company. There is still a higher level of attainment, almost beyond ambition, and that is to be able to take part, on fair terms, in a conversation with bright and intelligent Malay ladies. This is difficult because they use words and expressions not found in dictionaries and story-books, and they do not make allowances for ignorance or pretend not to hear mistakes. Quite the contrary, they are merciless in ridicule, especially if they are young.

To write, I will not say exhaustively, but to write at all fully of the Malay language and literature would certainly 
be a matter of a volume or two, and the subject would probably appeal to a very limited circle. In the early part of the last century there were three recognized English authorities on the Malay language, Marsden, Raffles, and Crawford ; the last named having been already mentioned as Major Farquhar's successor in the Singapore Residency. There were also a number of distinguished Dutch writers, but they dealt rather with the Malay of Java and Sumatra, which is not quite the same language as that spoken in the Malay Peninsula. The researches of Marsden and Raffles were also conducted mainly in Sumatra, and of the three English writers, all of whom took up the subject with enthusiasm and studied it with great diligence, Crawford wrote with probably the highest authority. The following extracts from a lecture and a paper by Crawford, both printed in 1848 , are of special interest as the thoughtful and reasoned views of a writer fully qualified to deal with the subject of the Malay language and the sources which carried it over so vast an area.

" Distinct and unequivocal traces of a Malayan ${ }^{1}$ language have been found from Madagascar to Easter Island, and from Formosa to New Zealand, over 70 degrees of latitude, and 200 of longitude."

"To account for this remarkable dissemination of a language, singular for its extent, among a people so rude, it has been imagined that all the tribes within the wide bounds referred to constitute, with the exception, however, of the Papuas or Negroes, one and the same race, and that the many tongues now known to be spoken by them were originally one language, broken down, by time and dispersion, into many dialects. This is the theory adopted by Mr. Marsden, Sir Stamford Raffles, and the Baron William Humboldt, as well as by many French and

\footnotetext{
1 "I use this word as a common term for all that belongs to the Archipelago."
} 


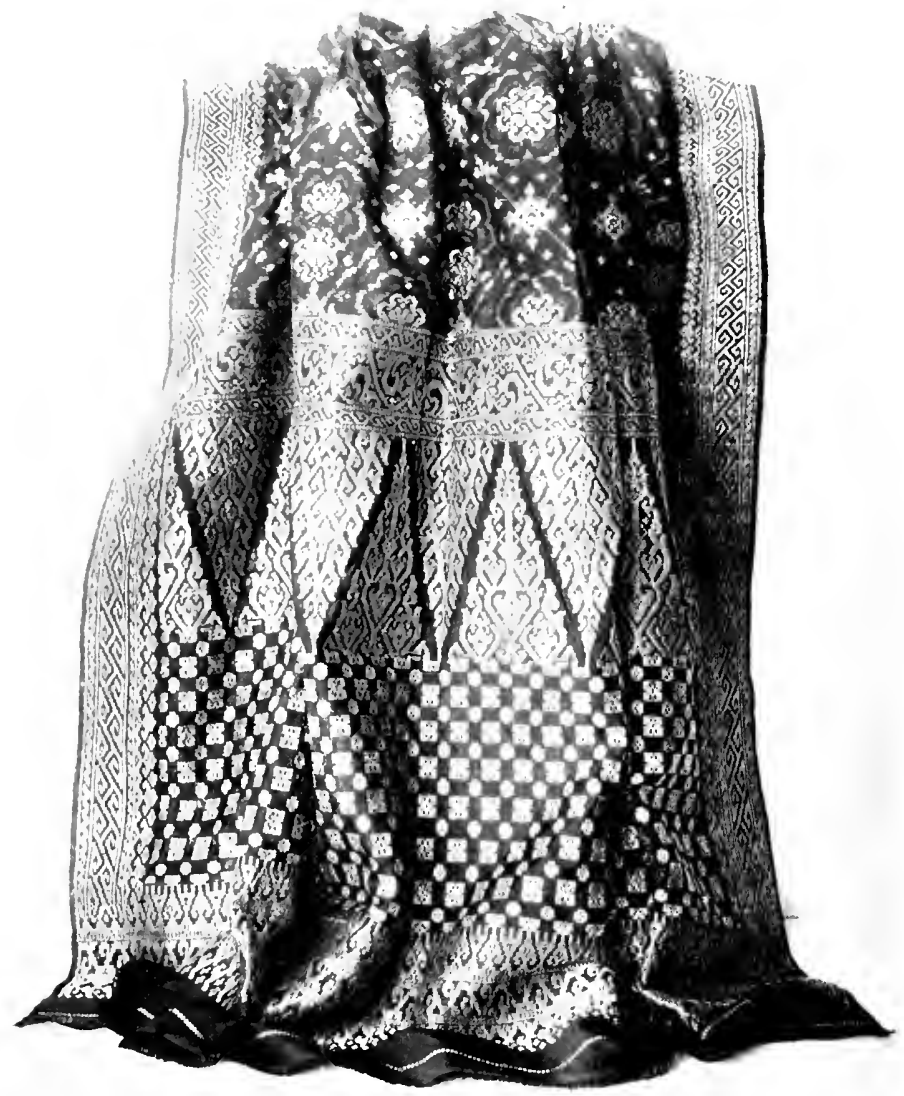

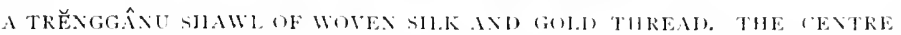

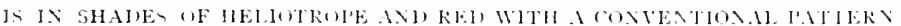

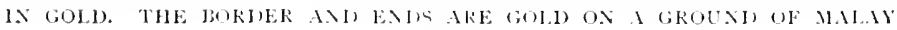
KEI 

German writers, but I believe it to be wholly destitute of foundation. ...

"A brief examination, phonetical, grammatical, and verbal, or glossarial, of some of the principal languages will, I think, clearly show that they are generally distinct tongues, not derived from a common stock, and that the Malayan words they contain have been engrafted on them as Teutonic words have been on the continental languages of Europe of Latin origin ; or as French words have been on our own Anglo-Saxon, although, indeed, the course through which this has been effected has been, in general, very different.

"The languages from which, in my opinion, the words so engrafted have been for the most part derived, are those of the two most civilized, numerous, and adventurous nations of the Archipelago, the Malays and Javanese. The Malayan words found in each language that has received them will, I think, be found not only numerous, but correct in sound and sense in proportion to the facilities, geographical, navigable, and lingual, possessed by the parties adopting them of communicating with the parent countries of the Malay and Javanese nations.

"The dissemination might be direct from Sumatra and Java, the parent countries in question, or indirectly from some nearer country; and it would happen through commerce, piratical expeditions ending in settlement and conquest, or by the fortuitous wreck of tempest-driven vessels, to all of which I shall, afterwards, more particularly allude. .... .

"When European nations first visited the Indian Archipelago, in the beginning of the sixteenth century, they found the Malays and Javanese conducting the first stage of that commerce in the clove and nutmeg, by which these then much valued articles found their way, first into the markets of Continental India, and eventually into those of Arabia, Egypt, Greece, and Rome-that is, 
making trading voyages which extended from the western bounds of the Archipelago. The spices in question were found in the Roman markets of the second century of our era; and the great probability, therefore, is that the Javanese and Malay trade alluded to had, when Europeans first observed it, been going on for at least fourteen centuries. ...

"Respecting the probable era of such adventures, we have just one faint ray of light. With the Malayan there came in a few words of Sanscrit, such as are popular in the Malay and Javanese. From this it may be fair to infer, that the chance migrations I have supposed, whether they had before taken place earlier or not, may have taken place, at all events, as early as the epoch of the connection of the Hindoos with the Indian Archipelago-a connection, the commencement of which cannot, I think, be placed later than the birth of Christ. . . .

"Within the Malayan Archipelago the Malay and Javanese languages have been communicated to others by conquest, settlement, or colonization, and commerce; while to Madagascar and the islands of the Pacific they have been communicated by the accidents of tempestdriven praus or fleets of praus.

"The insular character of the whole region over which a Malayan language has been disseminated, and the periodical winds prevailing within it which, on a superficial view, appear obstacles, are, in truth, the true causes of the dissemination, for had the region in question been a continent, stretching north and south like America, or lain within the latitudes of variable wind and storms, no such dispersion of one language could have taken place.

"Such is the most rational explanation I can render of a fact in the history of our race, mysterious without explanation, and wonderful enough even with it. ...

"The use of letters has been immemorially known to 
all the more civilized nations of the Indian Archipelago, of the brown-complexioned, lank-haired race, and many alphabets, at once distinct from each other, and not borrowed from any foreign source, are to be found among them, from Sumatra to the west, to Celebes and the Philippines to the east.

"Modern writers have supposed that the earliest writing was pictorial or hieroglyphic, and that in process of time this became vocal or phonetic, ending in literal alphabets. Of the truth of this theory, however, no evidence is to be discovered in the insular languages. Hieroglyphic writing is nowhere to be seen on any ancient monuments-the letters of the numerous alphabets which exist bear no resemblance to any object of nature, animate or inanimate - the names of the letters simply express their sounds, and the word for an alphabet consists, as with ourselves, only of an enumeration of a few of the first letters in order of which they are composed.

"The Javanese is certainly the most perfect alphabet of the Archipelago, and a brief account of it will give a general notion of the rest which, although they differ in form, bear it, in principle, a common resemblance. It has a distinct and invariable character for every sound in the language, and so far, therefore, it is a perfect system. . . .

"We have then, in all throughout the Archipelago, no fewer than nine distinct alphabets, every one of which appears to be a separate and a native invention. But they are not only distinct from each other; they differ equally from all foreign alphabets.

"Some, indeed, have fancied that the Malayan alphabets may have been borrowed from the Hindus, but there is assuredly no solid ground for such an hypothesis. Some improvements in details, there is no doubt, they did receive from this source, but on examination they are not found to be essential. The most striking of them is the 
organic and rhythmical classification. But two of the alphabets of Sumatra, the obsolete alphabet of Sumbawa, and the Javanese alphabet have not adopted this arrangement. The last of these is the most remarkable instance, for it was the one of all the characters of the Archipelago most amenable to Hindu influence, as is sufficiently attested by the greater number of Sanskrit words in the language of Java, and by the existence in that island of numerous Hindu monuments, including inscriptions in the Dewanagri, side by side with those in the ancient native writing. . . .

"In fact, the main characteristic of the Malayan letters, their differing among themselves, and then differing equally from all foreign letters, leads to the inevitable conclusion that each alphabet was a separate and independent invention, made, in all likelihood, in the localities in which we at present find them. If this be the case, the kind of fertility of invention which the fact evinces is a curious contrast to the utter absence of it in rude and early Europe, which never invented an alphabet, although in substantial civilization it is not to be imagined that the natives of Java and Sumatra two thousand years ago were superior to the energetic inhabitants of Germany, Gaul, and Briton.

"What causes conduced to this early invention of letters among Malayan nations, and at so many different and distant points, it is not very easy to say. It is certain that the discoveries must have been preceded by a very considerable advancement in civilization, such as would afford leisure to some class of men to attend to such things. That class was unquestionably a priesthood of some kind, and the first and earliest use of letters would assuredly be, not for the common conveniencies of life, or even for its amusement, as in a more advanced stage, but for the sheer purpose of conjuration or incantation. 
"The development of a civilization in which the invention of letters would spring up would require that the natural circumstances of a country should be favourable. The territory must be sufficiently large, and sufficiently fertile and easy of cultivation, to produce a population numerous enough for its own defence, and, therefore, to afford sufficient leisure to any class of its inhabitants. No respectable amount of civilization has ever risen, and no letters have ever been invented, in any country of the Archipelago destitute of these advantages.

"The nine alphabets of the Archipelago are the produce of five large islands only, out of the innumerable ones which compose it. The most fertile and civilized island, Java, has produced the most perfect alphabet, and that which has acquired the widest diffusion. The entire great group of the Philippines has produced, and that in its greatest and most fertile island only, a single alphabet; even this one is less perfect than the alphabets of the Western nations, in proportion as the Philippine islanders, when first seen by Europeans, were in a lower state of civilization than the nations of the west of the Archipelago.

"The Malayan Peninsula and Borneo, extensive as they are, have never given rise to an indigenous civilization sufficient to raise their inhabitants beyond the condition of small and miserable communities, and hence no indigenous alphabet can be traced to them. Their more civilized inhabitants are invariably stranger emigrants. This must be owing to the absence of a certain kind of fertility in the land available to the rude and feeble efforts of a native industry, such as elsewhere gave rise to a concentrated population, to leisure and to letters.

"No kind of native writing can be traced to the Spice Islands, which, notwithstanding their rich native productions, are incapable of yielding corn, iron, or cattle, the rough staples of early civilization, and without the presence of which letters have never been invented or existed. 
In the great island of New Guinea, with its savage negro population, and with the same deficiencies, the presence of any kind of writing is not reasonably to be looked for.

"No trace of a written character has been found in the wide extent of the islands of the Pacific. Most of them are, probably, too small to have furnished a population, at once sufficiently numerous and concentrated, to generate the amount of civilization requisite for the purpose. In the great islands of New Zealand, with their comparatively energetic race of inhabitants, the discovery of letters would, most probably, have been made, as among the rude nations of Sumatra, had the civilization necessary not been precluded by the absence, as in the smaller islands, of the larger animals for labour, and of all the cereal grasses for food.

"The facility with which materials to write on are obtained in the countries occupied by the Malayan nations has, probably, contributed something towards the early discovery of the art of writing. The want of them, on the contrary, is known to have proved a great obstacle to the progress of letters, and, probably, was to their invention in temperate regions. The absence of a good material in ancient Europe hindered the invention of printing, and its presence in China, no doubt, contributed largely to its early discovery in that country.

"The Indian islanders write on palm leaves, which have received no other preparation than that of being dried, and cut in slips-on the inner bark of trees, a little polished only by rubbing-on slips of the bamboo cane, simply freed from its epidermis, and on stone, metal, and finally on paper.

"The palm leaf employed is that of the lontar, or borassus flabelliformis. The Malay word is most likely a corruption of two words: ron, a leaf in Javanese, and tal, the proper name of this palm in Sanskrit. This seems corroborated by the Javanese name, which is written rontal. 


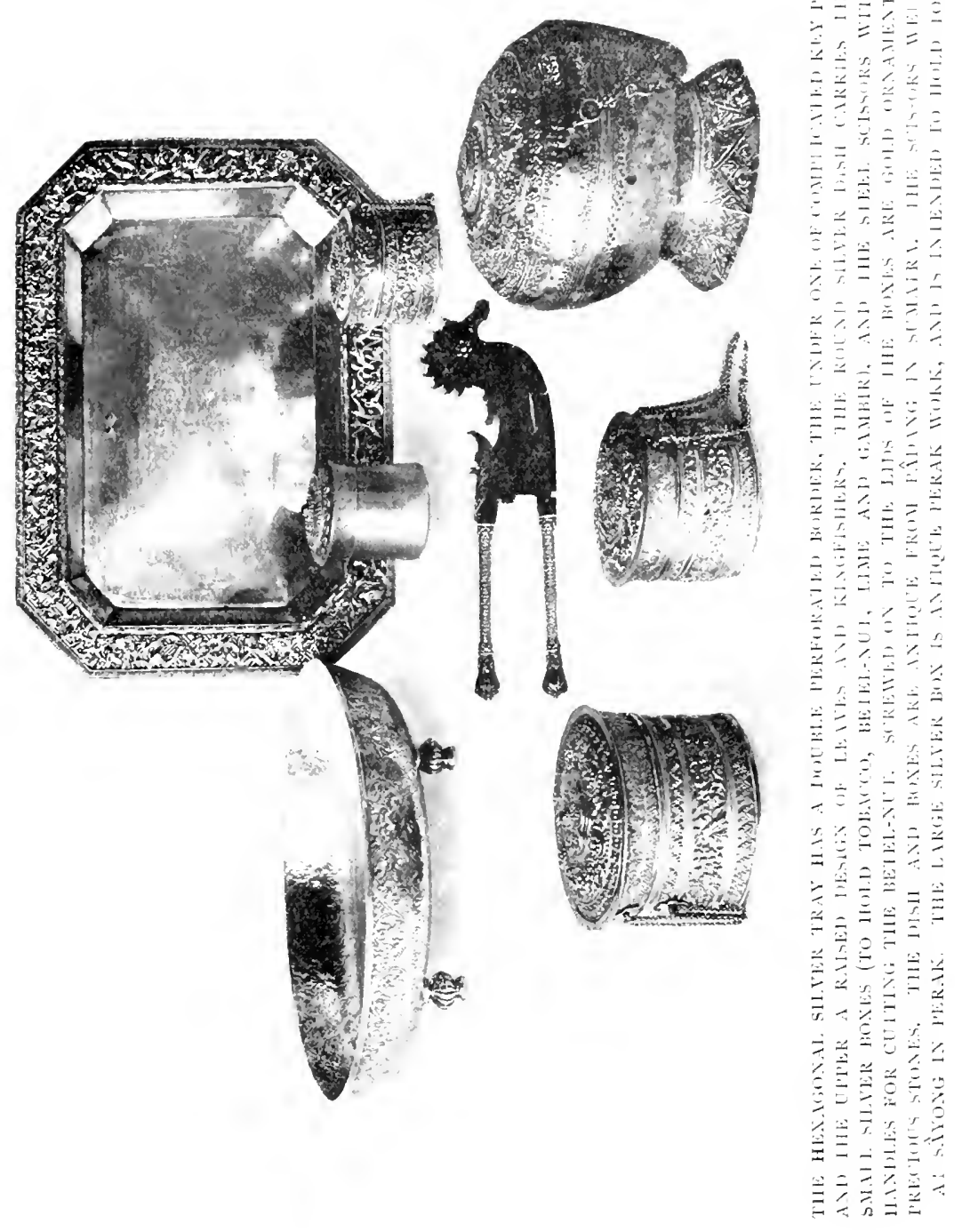

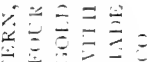

$\bar{b}=\overline{0}$

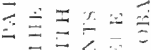

$==$

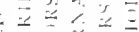

- $-1=$

$=-5=$

$\overrightarrow{5} \div$

$=2-$

$=-\overline{1}$

$5-\div=1$

示立二

兰 $\div$

有

․․를

皮二- -

完

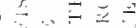

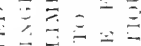

$+2=1$

$=5= \pm$

'

$r_{1}=$

$\div=0$

¿ $=$

$=2$

$\Rightarrow \vec{\square}$

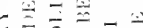

三

든

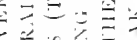

$-1=$

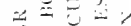

$\div=$

三

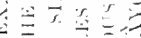

$=$ 二

采等 

From the use of this word it might, at first sight, be imagined that the practice of writing on palm leaves was derived from the Hindus. But it happens that this word, with many others wholly or partly Sanskrit, belongs to the ceremonial and factitious dialect of the Javanese language, a genuine native name, kropyak, existing for it, in the ordinary one, so that no safe conclusion can be drawn from this etymology.

The instrument for writing with on the palm leaf, bark, and the bamboo is an iron style, and their writing is, in fact, a rude engraving, which is rendered legible by rubbing powdered charcoal over the surface which falls into the grooves, and is swept off the smooth surface.

"The Javanese alone understand the manufacture of a kind of paper. This is evidently a native art, and not borrowed from strangers, as is plain from the material, the process, and the name. The plant, in the Javanese language, is called gluga (Brouponotia papyrifera), and the article itself dáluwan changed into dálanian for the polite language. The process is not the ingenious one of China, India, Persia, and Europe, but greatly resembles that of making the Egyptian papyrus, and still more closely the preparation of the South Sea cloth, the raw material being, indeed, exactly the same. The true bark, cut in slips, is long macerated and beaten, and after being thus treated, slips of it are joined to each other over a smooth surface, and defects made good by patching. The fabric thus obtained is of a brownish-grey colour, unequal in its texture, rigid but strong.

"With the exception of the Javanese, it does not seem that the natives of the Archipelago ever wrote with ink before they were instructed by the Arabs, no doubt from the absence of paper. The Javanese have a native name for 'pen' and 'ink'-süa and mansi; but with the other nations the only ones are Arabic-kâlam and dâwat, often, indeed, greatly disfigured, as in the example of the 
Bugis who convert them into kalah and dawak. The pen generally used is not reed, as on the Continent of Asia, or a quill, as in Europe, but a stub obtained from the Aren palm (Saguerus saccharifera).

"Even paper is generally known to the Indian islanders by the Arabian name of kartas, so that it is probable that a true paper was imported long before the arrival of Europeans, although the natives were never taught the art of preparing it. At present European paper is in general use by all the more civilized nations, to the exclusion of Asiatic."

I have quoted these extracts because of their authority, their interest, and the soundness of the reasoning by which Mr. Crawford supports his conclusions. Since the time of Marsden, Raffles, and Crawford, no Englishman has publicly discussed the same questions, and established with his contemporaries anything like the same reputation for Malay scholarship. It is certain that all the three writers named used great industry in their studies, but it is a pity that they confined their work to research into, and criticism of, the published results of what they and the Dutch authorities had already gleaned from the field of Malay letters. Some of the dictionary work is inaccurate; the original collector has gone wrong, and his mistakes have been perpetuated by the simple process of repetition. All the books by English writers are very incomplete, probably because the few who had an inclination for this form of study lacked opportunities for making thorough inquiry, and never realized how many and rich were the sources of information. Raffles' active mind was busy with too many important matters to allow him to give the necessary time for a careful study of the Malay language. Marsden's researches were mostly, or wholly, confined to Sumatra, and Crawford failed to go to the Malays themselves, from whom alone he could have gained a thorough and accurate knowledge of their 
language. In later years, with the opening of the Peninsula to Europeans, and with the special opportunities given to Government officers of exploring out-of-the-way places in all the States where English influence now prevails, and even beyond those limits, it has been possible to learn far more of the Malays and their language than ever was known by Englishmen before. These reasons induced Mr. Hugh Clifford (formerly British Resident in Pahang) and the writer to collaborate in the compilation of a Malay dictionary, in the hope that we might push the work done by our predecessors a little nearer to the distant goal of completeness. The scheme was, however, too expensive and exacting for unaided effort, and as it did not meet with any encouragement from the Government, we were obliged to abandon it, after putting only one-third-about five hundred pages-through the press. It is some consolation to know that Mr. R. J. Wilkinson, of the Straits Civil Service, has carried out a less ambitious programme, and produced a Malay dictionary which establishes his industry and scholarship, and does much to remove the reproach that no Englishman had attempted to compile such a work for nearly a hundred years.

Malays possess very few writings which can be dignified by the name of literature, and that is curious considering how well they know, and how diligently the most intellectual of them read, the best-known works when they can get them. As books written in the best style and of the greatest repute amongst Malays the following may be mentioned: the Sejâra Malayu (the Malay Annals already referred to), the Hikaiat Hang Tuah (the history of a famous Malay warrior who flourished in the sixteenth century), the Taj Al-salatin (otherwise called the "Crown of Kings"), the Hikaiat Iskandar Muda (the history of an Achinese Sultan), the Bĕstâmam and the Hoja Mêmun. There are also a number of less important works which 
are translations of Indian and Persian stories. In modern times the only book of any note written by a Malay is Abdullah's History. As already stated, this writer's style is far from classic, and his biography is not much read outside the Straits Settlements Colony.

Malays of both sexes, in their youth, are given to the writing of verses, like love-sick damsels and swains in other latitudes. These effusions are called pantun; they consist of verses of four lines, the first and third and the second and fourth rhyming; their peculiarity is that the first two lines often mean little or nothing, and have no real connexion with the last two, which alone embody the writer's message. Three examples are enough to give an idea of the style of these love ditties.

Nyior tinggi chondong ka-kota, Kain sôlok di-mâkan âpi.

Abang dâtang měn-dâpat kîta

Ka-mâna nak di-tolak lâgı ?

A lofty cocoanut palm leans towards the fort; The cloth of Solok make is burned in the fire. If my beloved comes to seek me, How can I send him away?

Sĕnûdoh kayu di rimba, Bĕnang kârap ber-simpul pûleh.

Sûnggoh dûdok běr-tindeh riba, Jângan di-hârap kâta-kan bûleh.

The sĕnîdoh bush grows in the forest; The strings of the loom are in a tangled knot. It is true that I sit on your knee, But do not hope for any further advantage.

Brâpa tinggi pûchok pîsang, Tinggi lâgi âsap api.

Brâpa tinggi gûnong mě-lentang

Tinggi lâgi harap hâti.

However high the stem of the banana, The smoke of fire goes higher still. However high the mountain range, My heart's desire is higher still. 


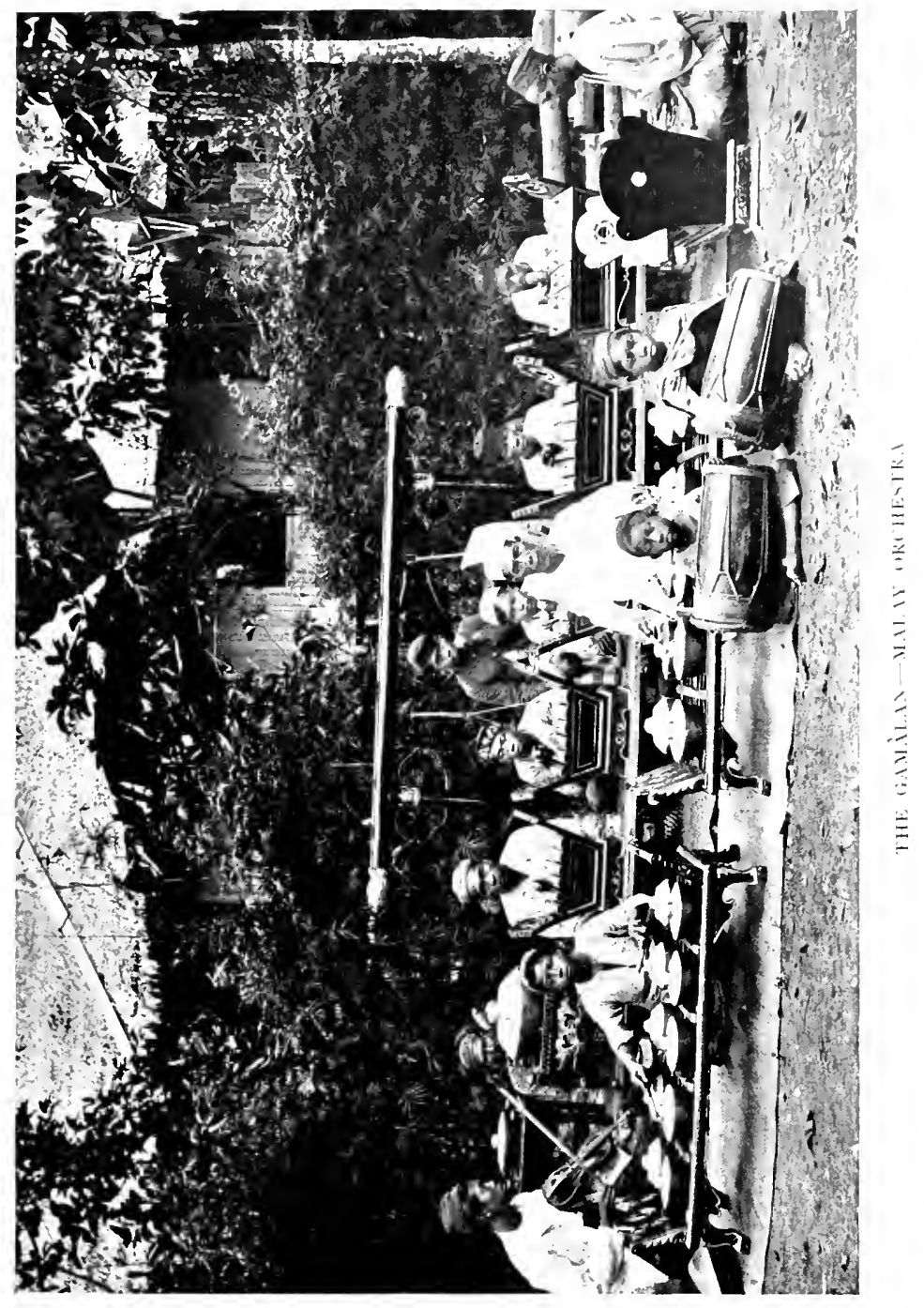



On any moonlit night, when the river shines like burnished silver, you may see a long, narrow dug-out, black against the water, with a Malay youth in the stern, poling up stream or paddling down, bellowing these pantun to the soft Eastern night; to relieve his feelings and, possibly, in the hope that they may reach the ears of his innamorata. If she is within half a mile she can hardly fail to hear him, and he is rather an attractive person the Malay boy.

Reference has been made to the Malay's fondness for proverbs, for epigrams and wise saws; in his conversation he never fails to introduce one or other, when he sees an opportunity for their fitting application. The following specimens of this "wisdom of the many and wit of one" will give the reader a good idea of the habit of the Malay mind, and how the people draw, from their surroundings and the common things of everyday life, ideas, metaphors, and injunctions with which to season their conversation.

"To hang without a rope"; said of a woman who is deserted but not divorced.

"It is in sugar that you see the dead ant" ; those who give themselves up to pleasure find death in the pot.

"What is cracked must break"; said of two people who are seeking for an excuse to sever their connexion.

"The house is finished, but there is still the sound of the chisel"; trying to reopen a matter which ought to be settled.

"The owl sighing for the moon"; hankering after the impossible.

"Like writing on water"; wasted energy.

"Like a crow returning to his own country"; to return as you came, no richer nor poorer.

"To move like a wounded snake"; said of a very lazy person.

"As inseparable as the quick and the nail"; the closest friends. 
"The elephant makes a wide track through the jungle without killing the ants on which he treads"; said of a person very particular in certain observances but ignoring defects in himself which are patent to every one.

"Out of concern for the sârong to throw away the jacket"; probably losing both. It is said of a man who wishes to get rid of one wife in order to secure another.

"To light a fire on the roof" ; to pretend to be very useful while really doing the extremity of harm.

"The bean forgets its pod"; ingratitude.

"Four is odd and five even"; a definition of untrustworthiness.

A house where the wife rules is spoken of as "a boat steered from the bow."

"To love one's children one must weep for them sometimes, to love one's wife one must leave her sometimes."

"You may bale out a sinking boat, but in a shipwreck of the affections the vessel founders."

"A wound heals, but the scar remains"; one forgives but does not forget.

"In full daylight, he still carries a lighted torch"; a definition of the upright man who has nothing to conceal

"Bored with life, but unwilling to die"; said of a very lazy and useless person who is only a burden to others.

"Will a man put his salt out in the rain ?"; will a man publish his own dishonour?

"Can you cover the sun with a sieve?"; a great crime cannot be concealed.

"Poison is harmless when handled by experience"; hatred and prejudice cannot hurt those who know how to deal with them. So on a day when the atmosphere seems all sunshine, one sees a great kite fall like a stone into a swamp and, instantly rising again, fly slowly to the top of some high tree carrying a snake in his talons, but so held that the reptile is quite powerless. Then, at his leisure, the kite makes a meal of his enemy. 
"Standing like a pawned spear"; said of the awkward person, who moves about uncomfortably instead of sitting down at his ease and joining in the conversation.

"Enmity with a wise man is better than friendship with a fool"; the former may change, the latter can never be of value.

"Don't borrow from new-made men, or visit the newly married"; in either case you will make a mistake.

"To pole down stream makes crocodiles laugh"; the height of absurdity.

"People help to prop up what is firm and stamp on what is down"; human nature wishes to be on the winning side.

"When the key is wicked, the box may turn traitor." If a man is unfaithful, he can't be surprised if his wife betrays him.

"If you smack water in a dish, some of it is sure to fly in your face" ; curses come home to roost.

"A year's drought is washed away by a day's rain"; an hour's joy drives out the memory of months of sorrow.

"Those who quarrel with the well must end by dying of thirst" ; life is hard enough, do not add to its bitterness by refusing all that makes for happiness.

"While you carry the Raja's burden on your head, do not forget to keep your own bundle under your arm." Duty to your country and King come first, but your own affairs have a claim on your attention. ${ }^{1}$

In conclusion, it should be mentioned that the Malay language has a peculiarity which is found in other eastern tongues. Certain special words are used when speaking of people of royal birth which are never applied to persons of lower rank. For instance, when referring to the eating, sleeping, bathing, dwelling, journeying, or commands of a Raja, terms are employed which are never

1 In the selection of these proverbs some use has been made of the collection published by the late Sir William Maxwell in the Journal of the Straits Branch of the Royal Asiatic Society. 
used in the case of ordinary mortals. Ceremonial is strictly observed between persons of different classes and different ages, and this is specially the case in the use of the personal pronouns, of which there are many forms, each with its recognized application as between those of different social status and on varying degrees of familiarity. Even children in their play never employ the wrong word. 


\title{
CHAPTER VIII
}

\author{
I 874
}

SIR ANDREW CLARKE-BRITISH INTERVENTION IN THE AFFAIRS OF THE WESTERN MALAY STATES

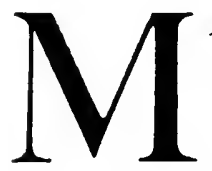

ajor-General Sir Andrew Clarke, R.E., K.C.M.G., the new Governor, Commander-inChief, and Vice-Admiral of the Straits Settlements, arrived in Singapore on 4 November, 1873. The very lamentable state of Malay affairs had, from time to time, been reported to the Secretary of State for the Colonies, and Sir Harry Ord, while he made no suggestion for dealing with the situation, had expressed his regret that, as he was precluded from interference, he could do nothing to improve matters beyond offering advice that the various disputants should meet and settle their differences. If I have been able to give any idea of the conditions which then prevailed in the western states, it will be obvious that this advice was not, nor was it likely to be, accepted. Where all classes and nationalities are in arms fighting for different causes or different leaders; where neither life nor property have any safeguard, except the owner's strength and will to defend them; where robbery, or murder, or any other crime, meets with neither inquiry nor punishment, peace and order will not be restored by any voice from inside the disturbed regions, and the wisest counsels, unsupported by power to enforce them, will be given in vain. 
Lord Kimberley had, however, furnished Sir Andrew Clarke with instructions of the first importance, showing a disposition to make an entirely new departure, and to recognize the duty forced upon England, as the dominant Power, to interfere in the Malay States and put a stop to a disgraceful state of affairs. The duty was imperative from motives of humanity alone; but it was equally certain that to undertake it would be highly beneficial to British interests and British trade, though these pleas had hitherto been dismissed as of no importance. The most timid British taxpayer will probably admit that it is not wholly unjustifiable to define more clearly an existing responsibility, in order to create and to keep a trade which is wholly, or almost wholly, British, and worth $£$ i 2,000,000 annually.

Neither Lord Kimberley, nor Sir Andrew Clarke, nor any one else, could see so far into the future as to guess the result for which those figures speak, and it is safe to say that, while the Colonial Secretary desired to use British influence to save the Malays from themselves and give them the blessings of peace and justice, the Governor found it intolerable that the colony, for which he was responsible, should be harassed by the misgovernment of its neighbours.

In Sir Andrew Clarke's instructions, dated 20 September, I873, were the following passages :-

"Her Majesty's Government have, it need hardly be said, no desire to interfere in the internal affairs of the Malay States. But looking to the long and intimate connexion between them and the British Government, and to the well-being of the British Settlements themselves, Her Majesty's Government find it incumbent upon them to employ such influence as they possess with the Native Princes to rescue, if possible, those fertile and productive countries from the ruin which must befall them if the present disorders continue unchecked. 
"I have to request that you will carefully ascertain, as far as you are able, the actual condition of affairs in each State, and that you will report to me whether there are, in your opinion, any steps which can properly be taken by the Colonial Government to promote the restoration of peace and order, and to secure protection to trade and commerce with the native territories. I should wish you especially to consider whether it would be advisable to appoint a British Officer to reside in any of the States. Such an appointment could, of course, only be made with the full consent of the Native Government, and the expenses connected with it would have to be defrayed by the Government of the Straits Settlements."

Here, then, for the first time, was the germ of the residential idea, though Abdullah, writing to Sir Harry Ord not long before, had gilded his plea for acknowledgment as Sultan of Pêrak, by requesting that a British officer might be sent to him to teach him how to rule the country. That request he repeated to Sir Andrew Clarke shortly after his arrival, and the Governor, having made all the inquiries necessary for his purpose, at once decided on the line of action.

Lord Kimberley's instructions were as wide as could be wished, and they contained a valuable and definite suggestion; but they invited the Governor to report his proposals, and Sir Andrew Clarke, a man of energy and decision, ready to take any responsibility, decided that this was no time for talking; the situation demanded immediate action, and he would take it, reporting what he had done, not what he proposed to do. Naturally the Governor did not come to this conclusion until he had gone thoroughly into the case, taken the advice of all those who had any knowledge of Malay and Chinese affairs, and felt confident that he could carry his plan to a successful issue.

At that time there was, in Singapore, a very remarkable 
and able officer in charge of Chinese affairs, Mr. W. A. Pickering (afterwards created C. M. G. for his many public services), and he was sent to Pinang to endeavour to persuade the heads of the Chinese factions, then warring in Lârut, to agree to accept the Governor's settlement of their differences. In this duty Mr. Pickering was entirely successful, and, as soon as he had telegraphed the result of his negotiations, the Governor started from Singapore in the colonial yacht for the island of Pangkor lying off the coast of the Dindings, near the mouth of the Pêrak River. The Governor sent ahead, or took with him, Mr. Bradell, the Attorney-General ; Major McNair, R.A., the Colonial Engineer; Colonel Dunlop, R.A., the Inspector-General of Police; and Mr. A. M. Skinner of the Secretariat, the party reaching Pangkor on I 3 January. Meanwhile, by the Governor's instructions, I went from Pinang to Lârut on board H.M.S. Avon to tell the Chinese that their friends in Pinang had agreed to suspend hostilities, and to invite the Mantri, and any other chiefs who could be got at, to meet Sir Andrew at the rendezvous on 15 January. By that date it had been possible to collect at Pangkor, Raja Abdullah, his relative Raja Idris (the present Sultan of Pêrak), and the chiefs who were his adherents, also the Raja Bĕndahâra, the Mantri, the Tĕmĕnggong, and the Dato Sâgor ; but Raja Ismail and Raja Yusuf were too far away, and made no effort to attend. Mr. Pickering and the heads of the Chinese factions were also present.

After some days of discussion an instrument was drawn up in English and Malay, and was signed and sealed on 20 January, 1874 . It is known as the Pangkor Engagement, or Treaty, and provides, amongst other things, for the recognition of Raja Abdullah as Sultan of Pêrak, and the grant of the title of Ex-Sultan to Ismail, who is to hand over the regalia to Sultan Abdullah.

The two most important clauses are as follows :- 
Clause VI. "That the Sultan receive and provide a suitable residence for a British Officer, to be called Resident, who shall be accredited to his Court, and whose advice must be asked and acted upon in all questions other than those touching Malay religion and custom."

Clause X. "That the collection and control of all revenues and the general administration of the Country be regulated under the advice of these Residents."

The Mantri was confirmed as the chief in charge of Lârut, with an Assistant Resident, and Captain T. C. S. Speedy was immediately appointed to this latter office.

As soon as the document had been signed and sealed the Sultan was saluted, and he and his chiefs returned to their homes in Lower Pêrak. The heads of the Chinese factions then signed a bond, undertaking, under a penalty of $\$ 50,000$, to disarm, to destroy their stockades, give up their row-boats, and not again to break the peace. At the same time a commission, consisting of Colonel Dunlop, Mr. Pickering, and myself, with the leaders of the Go Kuan and Si Kuan factions, was appointed to at once see that these promises as to the destruction of forts and the rendering up of all arms were faithfully observed, to arrange for a settlement of the dispute concerning the ownership of the mines, and to affect, if possible, the rescue of a number of Chinese women and children said to be detained in captivity by one side or the other.

The Governor and his party then returned to Singapore, and from there Sir Andrew sent a report of his proceedings to Lord Carnarvon, then Secretary of State for the Colonies. As soon as the facts were known the Chambers of Commerce of both Singapore and Pinang wrote letters of congratulation, and the Governor's action was received with high approval by all classes and nationalities in the colony.

As the result proved, this new departure was not to be all plain sailing; indeed, the real difficulties had not even 
begun. They were to last for years, and only after the loss of many valuable lives, the expense of infinite persistence and resource, did this novel experiment end in complete success. It is one thing to send two or three white men into a country where none of their kind have ever been seen before; to tell them to advise those whose minds and traditions are crooked to follow the straight path and never deviate; to endow them with the sole authority to collect and expend all revenues, and to regulate the general administration of the country, with no force behind them but their own courage, tact, ability, and the spectre of British power, miles away in the dim and shadowy background. It is quite another thing to evolve peace and order and prosperity out of these difficult conditions.

Still one cannot say too much for the new departure. It was action, instead of a culpable inaction, a craven shirking of responsibility; it was the opportunity which had long been so earnestly desired by Englishmen who believe there is no web so tangled but they can unravel it, no problem so complex but they will find a solution. Lord Kimberley gave Sir Andrew Clarke the right to open the door of the Malay Peninsula; he even suggested where he might find the key. The permission was entrusted to the right man, and Sir Andrew straightway put the key to the lock, opened the door, and left the rest to his agents and successors.

The first actual work was entrusted to the Commission appointed at Pangkor, and they lost no time in setting about it. The result of a month's hard and ceaseless travelling in boats and on foot was the complete destruction of all stockades, the collection of a large quantity of arms and ammunition, the rescue and restoration to their own people of forty-five women and children, held captive and hidden away in remote places in the jungle, and the settlement of the dispute as to the ownership of the mines, 
with the delimitation of areas within which the rival factions should in future be allowed to take up land. That bald statement gives no idea of the difficulties with which the commissioners, absolutely unsupported in all out of the way places, had to contend, or how they were dealt with. For the most part, the means employed were the only ones available - tact and firmness, with an accent on the latter. As a sample of the conditions under which it was then necessary to travel about the country, the following extract from the report of the Commission will suffice. The members of the Commission, three Englishmen, one Chinese (the head of the Si-kuans), and their servants, had to make their way by a branch of the Lârut River to a point from whence there was said to be an elephant track to the Mantri's village, and the Mantri had promised to send elephants to meet the party at the point where they would leave the river for the land journey. The report, of which I was the writer, tells the rest.

"February I2, I874. We anchored off the Lârut River at 4 a.m. and at 5.30 stood in. About 9.30 a.m. the captain ran the vessel aground, and told us that we should have to wait several hours, till the tide turned, before we could get off. This, of course, we refused to do, and as we had done the day before, we got out the kedge, hauled the vessel off, and finding the right channel, reached the Mantri's stockade at I a.m. We heard there that everything had been ready for us the day before, so we knew that probably it would not be so to-day, and, with this to look forward to, we started, towing a big boat and a small one, to take us up the Limau River when the channel became too narrow for the steamer. A pilot took us into the river, and at 2 p.m. the s.s. Johove could go no further, so we all got into the big boat. She was so intensely slow that, after half a mile's progress, we were obliged to change into the small boat, and here our real 
troubles began. This boat would only just carry us and our baggage, so we had to leave the servants and some of the things behind for a second trip. After going perhaps three miles in the boat, there were only a few inches of water, so we had to get out and walk in the river. The boatman and I dragged the boat, thus lightened, a few hundred yards further, and then I left him in charge and pushed on after the others, whom I found, half a mile higher up the river, in an old stockade on the bank of the stream. Here, with some difficulty, we found a few Chinese, and persuaded them to go and fetch our luggage and send the boat back for the servants. The things came in a short time, but the servants did not arrive for an hour and a half.

"Meanwhile we had ascertained that, the day before, there had been five elephants for us; now there was only one, and that one had come by accident. We were therefore obliged to compel the Chinese to carry our things through the jungle to Bukit Gantang, and we sent them off at once. At 5.50 p.m., daylight closing, we fourDunlop, Pickering, Ah Yam, and I-mounted the solitary elephant, the interpreter and three servants following on foot.

"The elephant was the slowest, and the path the worst, that it has ever been my misfortune to meet. In fact, the path was no path; it was a 'slough of despond,' as indeed we found to our cost. It had been raining at intervals all the day, and the track, where it was not an unbroken stretch of water, was a succession of holes, at least two feet deep, and full of water. These holes had been made by the feet of elephants walking over the track. After an hour's progress it became darker than I have ever known it before, and darkness in dense jungle feels at least doubly dark. We could no more see our own hands than if they had been in the next State, so we were obliged to abandon ourselves entirely to the sagacity 
of the elephant, and never knew whether he was off the track or on it, or whether there was a track at all. We were sitting back to back, on some wet grass, in an open pannier, with no covering of any kind, and, to make us thoroughly miserable, it began to pour with rain-buckets of tropical rain-and never ceased till late the next morning. We had no waterproofs, and umbrellas were impossible; they would have been torn to pieces by the branches we could not even see.

"If we were miserable, our servants were in a far worse case. Floundering through mud and water, tumbling over fallen trees, and tearing through briars and thorns, all in pitch darkness, I believe they wished for a speedy end to save them from their intolerable woes. Indeed, they were in constant fear of being carried off by tigers, and as they could neither see the elephant nor each other, we tried to keep them together by constantly shouting to them, and by the two men who sat behind on the elephant smoking without ceasing. Those on foot followed our voices and the lights of our cigars for many miles. Occasionally the elephant, either frightened or doubtful of the road, would turn right round, and the servants were then obliged to scatter into the jungle, and wait there until he made up his mind to go on again; when he did go, there was no little difficulty in getting them back on to his track. Sometimes the elephant would put one foot forward, then wait and consider for quite a minute whether he knew the road or not. When he stopped altogether, we had to call to the servants, to prevent their running against him and frightening him; for an elephant is always afraid of anything that comes up behind him, and either slews suddenly round or lashes out with a hind foot. When we could smoke no more we struck matches, as well as we could in the storm of rain, until our supply was exhausted. We crossed three considerable rivers in flood. We saw nothing, but we felt the 
elephant make preparations as though to stand on his head; then he evidently slid down a steep bank; we heard him ploughing through the water, and held on for our lives as he crawled up the opposite bank. How the servants got across I can't imagine; they only did it by keeping together, spurred on by the fear of being lost in that inhospitable forest.

"But I feel it is impossible and absurd to attempt to describe what we went through that night; "nor pen can write, nor tongue can tell' the misery we endured, nor will any one who was there easily forget it. When we had almost given up all hope of getting to our destination before daylight, we came out on to the road, at Changkat Jering, and there, in a deserted house, we found some of the Chinese who had taken on our luggage. The rain was still pouring in torrents, and the Chinese Commissioner, declining to go a step further, took refuge in the deserted hut; but we preferred to go on, so we abandoned the elephant, and after walking three miles through mud and water, we reached Bukit Gantang between I I p.m. and midnight. We woke up Captain Speedy, who had given us up, and as we had eaten nothing since breakfast, he entertained us royally. We were wet through, and our luggage being still on the road, we borrowed some sacks as night clothes, and in the absence of mosquito curtains, wrapped ourselves up in old tents and were soon fast asleep."

My impression is that that jungle has never been crossed by Europeans since.

The Commission visited many out-of-the-way places in the Lârut, Krian, and Selama districts, in search of the captive women and children, and finally crossed the defile between the Lârut and Pêrak valleys, reached the bank of the Pêrak River at Kuala Kangsar, secured a country boat, and, in her, paddled a hundred miles down the Pêrak River to the village of Sultan Abdullah, where they found their steamer and returned to Pinang, having completely accomplished their mission. 
In November, 1873, a Malacca trading boat had been pirated at the entrance to the Jugra River, a tidal creek which joined the Langat River at the spot where the Sultan of Sellangor was then living. Of the crew only one man escaped death, by slipping over the side and clinging to the rudder till the danger was past and he was able to swim ashore and, in the course of time, make his way to Malacca. Not long afterwards this man reported that some of those concerned in the crime had come to Malacca, and they were duly arrested. In February, I874, Sir Andrew Clarke arranged with Sir Charles Shadwell, the Admiral of the China Fleet, who happened to be in the Straits, to join him in a naval demonstration at Jugra. The Governor took his yacht up to the Sultan's village and managed to get the Sultan to visit him, when Sir Andrew pointed out the disgraceful state of affairs which had so long continued, and asked the Sultan to give satisfaction for the recent ease of piracy. The Sultan proved most amenable, promised to assist his Viceroy to establish order in Sĕlangor, and as regards the case of piracy, in which one of his own sons was implicated, gave full authority for the trial of the accused, but expressed his own opinion of the trivial nature of the affair by describing it as "boys' play." The prisoners were then tried by the Viceroy, and on the evidence of the sole survivor of the murdered crew, a number of Langat men were duly identified, convicted, and condemned to death. When the result of the trial was communicated to the Sultan, he sent a kris to be used at the execution; the sentence was then carried out, the Admiral and the squadron sailed away, and the Viceroy was left with the éclat of these proceedings to quicken his authority.

It was not till later in the same year that I took up my abode in Bandar Langat-the "City of Festivals", as the mud swamp was otherwise named-but when I had been there a few months and was on terms of close 
intimacy with the best society, I ascertained that the men who had been executed were not responsible for this particular crime, though the punishment must have been deserved on general principles. The evidence of the Malacca witness was positive and unshakable, but it is probable that his own state of mind would not allow him to take very careful note of the features of the assailants at the moment of attack, and from the rudder he would not, on a dark night, have a very clear view of the subsequent proceedings. The effect produced by the trial and execution was all that could be desired, for there has never since been a case of piracy on the Sĕlangor coast, and from that day forward the Viceroy's authority was not seriously disputed.

In March, I874, Lord Carnarvon gave his qualified approval of the steps taken by the Governor to give effect to the instructions he had received from Lord Kimberley, and, in May, after a debate in the House of Lords, the Secretary of State expressed his full sanction in generous terms.

In May, I 874, Sir Andrew Clarke invited the chiefs of Sungei Ujong and Rĕmbau to meet him at Sermpang in the Linggi River, the point where the main stream forks, one branch draining Sungei Ujong and the other Rĕmbau. The Rĕmbau chief failed to attend, but the stockade at Sermpang was destroyed, and the Governor returned to Singapore satisfied that his action, and the visit of the two men-of-war, would impress the Malays with a conviction that misrule would no longer be tolerated.

In order to convey a correct appreciation of the various events which mark the establishment of England's influence in the Malay States, it is necessary to jump from place to place, and from incident to incident, in a way which can hardly fail to be irritating to the reader. Thus it is that I must return once more to the Sultan of Sĕlangor, to chronicle my own appointment, as British 
Adviser, to the Court of that delightful potentate. The Governor was still receiving letters from the Viceroy expressing his fears that the Sultan's sons were disloyal and secretly encouraging his enemies; so, in August, Sir Andrew Clarke again visited Langat and left me there, with twenty Malay constables, to do what I could to keep the Sultan up to the high level of his expressed intentions. The police and I lived together in a very unattractive residence; it was an old stockade with walls made of logs of wood, piled one on top of the other, a high-pitched roof of palm leaves, very far from watertight, the bare earth for floor, and two open spaces at either end for doors. The only path in the village passed right through the stockade, and the smallest effort would throw anything through one door-space into the river. Reeds, rank grasses, and jungle undergrowth grew up to the walls, and, at high tide, i.e. twice in every twenty-four hours, very little of the mud floor was left uncovered by water. The top of the log wall was well above high-water mark, and there one could sleep in luxury, except when it rained, and that was on about half the nights in the year. But I have been in worse places, and one of the great advantages of this residence was that you could make a fire anywhere within the walls without fear of burning a hole in the floor, and the log walls afforded an almost inexhaustible supply of fuel. A fire was not required for heating the premises, the temperature varied from $92^{\circ} \mathrm{F}$. in the day to about $75^{\circ} \mathrm{F}$. or $80^{\circ} \mathrm{F}$. at night, but smoke was absolutely necessary to defend oneself against the attacks of the most numerous and bloodthirsty breed of mosquitoes within a thousand miles. So one made plenty of smoke and sat in it. Outside, the prospect was singularly unlovely; a few score of blighted cocoanut palms, with broken and drooping fronds, like the plumes of a hearse returning from a disorderly wake; some particularly disreputable and tumble-down huts; 
the dark-brown waters of two deep and eddying streams; and all the rest mud and rank brushwood. When the tide went down, and the sun drew a pestilential vapour from the drying ooze, horrible, loathsome crocodiles crawled up the slimy banks to bask in the noisome heat. And every day great pieces of these banks, undermined by the violent onslaughts of the tide, fell helplessly into the stream, dragging in their fall some over-tired palm, some misshapen jungle tree, to lie with its head in the swirling water, its roots, torn from the ground, standing ragged and unnatural against a background of grey sky. If I was not perceptibly affected by the gloom of these surroundings, I gathered from the one or two strangers who visited me that they thought them rather uncanny; but then the stranger never stayed long enough to appreciate the excitements of the City of Festivals.

My police guard was at first composed of Malacca Malays; but as they grew homesick and became terrified by the stories they heard in the village, they were replaced by an equal number of men from Singapore, not so mild or well behaved, but better fitted for the duty. In the months which followed I travelled by steam launch, boat, and on foot over every district in the State; they were laborious days and full of surprises, nearly always of an unpleasant description, but it was all new, useful, and crammed with incident and interest. I wandered into Pêrak on one side, returning by a march of many days, and an eventful journey down an unexplored river, where for three days we (there were four Malays with me) never saw a human being or a habitation. I strayed into Sungei Ujong and paid a surprise visit to the old Dato' Bandar, the "Water Lord" of that State. $\mathrm{He}$ was not over cordial, but when he heard that, for the first time, there was a white man in his village he sent a message to say he would see me, and he took the trouble to explain some of the causes of his difference with the rival King, the "Land 


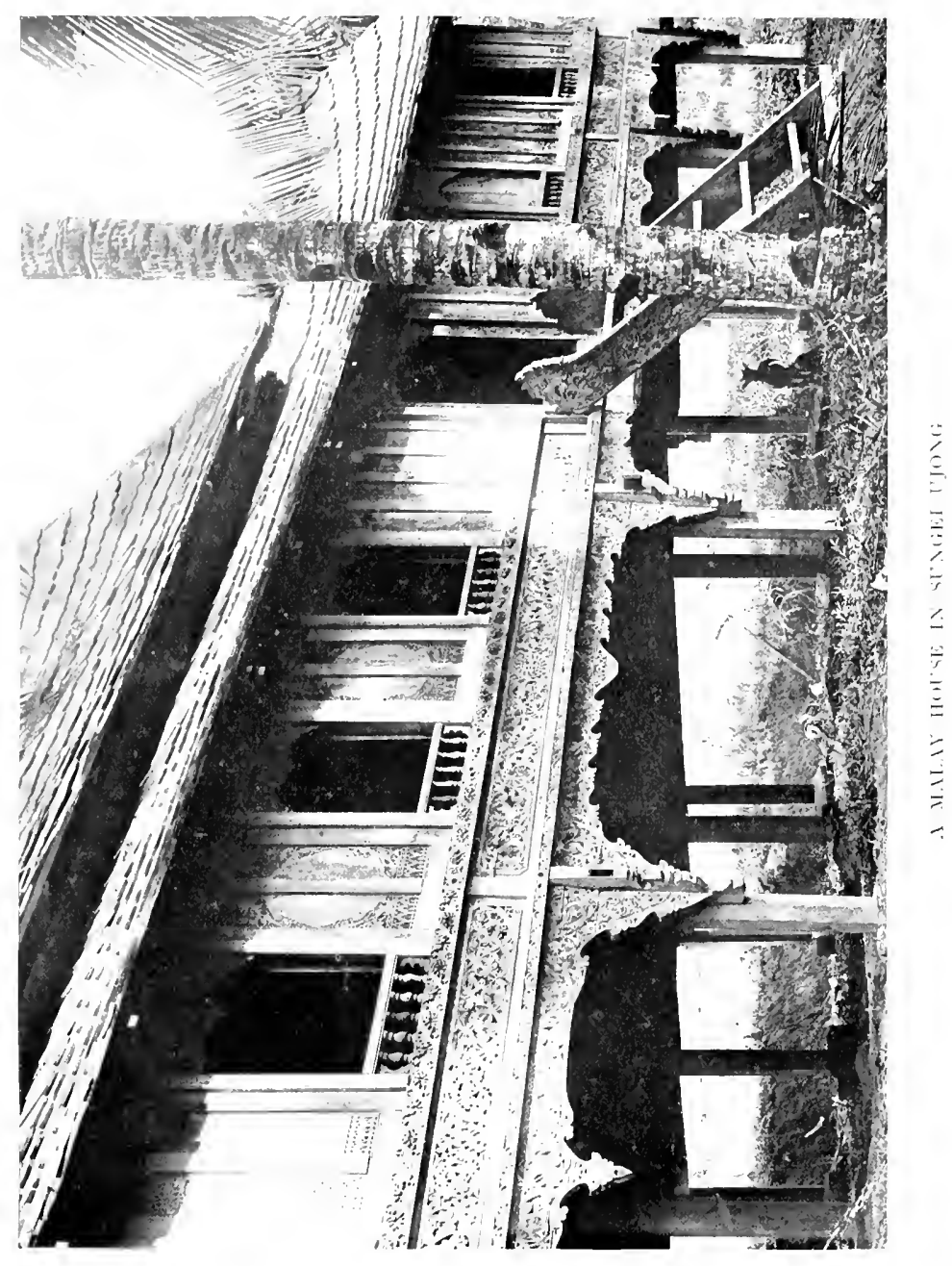



Lord." I walked on to visit this latter chief and found with him Mr. Pickering, who had been sent up in October in response to an urgent request from the Dato' Klana (he was the Land Lord) that the Governor would help him to bring the Dato' Bandar to reason. The Dato' Bandar was passing old, as Malays go, and also passing wicked, even for his age and times; but he had far more character than his younger joint-chief, and declined absolutely either to change his ways, give up any of the privileges he claimed, or come to terms. The Governor had written him several letters and bidden him to a meeting; but he declined all advances, refused to see any one, and elected to remain in his tents; that is to say, he remained in his own stockaded village, a place called Kapâyang, and practically invited any one to come and draw him who liked the job. It was not my business, but so far as I could see it was a very pretty quarrel as it stood, and from what I heard from Pickering, it was not likely to be left there.

Mr. Pickering had with him a few police and an English serjeant, and his mission was to see fair play and prevent the Chinese miners from joining one side or the other, should they come to blows. After a protracted correspondence and several interviews between Mr. Pickering and the old Dato' Bandar, the former decided that the Water Lord would not resort to armed resistance, though he declined to meet the Dato' Klana, or to admit that this chief had any higher authority in the country than he possessed himself. Mr. Pickering therefore decided to return to Singapore, and in order to do this he had to walk to the coast. As a side-light illustrative of the changes and chances of mortal life in the Malay States at that time, the following extract from Mr. Pickering's journal is interesting :-

" 7 November, 5.30 a.m. Some Malays brought a report that two Chinese had been murdered by supposed Rĕmbau 
men yesterday afternoon, between here and Permâtang Pâsir. 6.30 a.m. started again and found the road worse than ever, a muddy swamp, half a mile broad, commencing the journey, every step taking you up to the thigh in sticky clay. However, I think jungle travelling does not affect the health much, as one soon gets warm, and a course of phlebotomy by leeches takes the heated blood away from the constitution. At 7 a.m. we arrived at Linsum, the Dato' Akek's territory. Here his men met me, and called me to look at a dead Malay, who had just been able to reach this house when he dropped dead; another man was here, wounded; these were the men we had heard about. I saw the dead man, and turning him over found a shot wound in his left breast. After that I visited the wounded person; he had a shot wound on his right side which had gone through him, but he did not seem in danger. I interrogated him; his story was as follows: 'My name is Haji Mahmud; I am a small trader to Sungei Ujong, and live at Rambun China Besar, in British territory. Yesterday morning I, Sulong Iman (from Rambun China Besar), and another man started from Permâtang Pâsir to Sungei Ujong; Sulong Iman had a burden of rokok grass, and I had ten dollars on my person. The other man's name I don't know; he joined us at Permâtang Pâsir. When about three miles from this, about I p.m., six or seven men attacked us. My head was down-I could not distinguish their faces. Sulong Iman was shot dead, I and the other man were wounded; they took my money, and I ran with the other man here, where he died. I think they must be Rĕmbau men, but I don't know. Sulong Iman's body is in the jungle.' Some of the Dato' Akek's men offered to accompany us on our way and look for the body; after going about four miles, in the depth of the jungle we found the man's body, and close to it my feet stirred up a pool of blood. The man lay beside his burden, and a shot wound was in the 
back of his head. After we had passed the part where robbers most frequent, the Dato' Akek's men went back, promising to bury the body, and said they had sent word to the Dato and would make every inquiry into the case. From 8.30 to noon we went through dense jungle and deep swamp, without a sign of cultivation. After this the country is open and covered with short grass. ... I had sent the letter for the Toh Muda ahead; when I arrived at his place he was as hospitable as he could be during the Fast, and sent men to get me a boat for Malacca. He and his people complained much of the Dato' Bandar, as the only man now obstructive in Sungei Ujong. At 3 p.m. got a small boat with three oars, which was to take us down to Malacca. As we were four men in all (two police, self, and servant) we could not sit down, and the boat had no cover; we were not very comfortable, but on the other hand we were sure to catch the steamer. 6 p.m. at Kuala Linggi (twenty miles from Malacca by sea), heavy rain.

" 8 November. Men had been pulling all night, and at daylight were off Tanjong Kling. 7.30 a.m., reached Malacca. 8 a.m., called on the Lieutenant-Governor and reported the murder of the Malacca men."

As the state of affairs reported by Mr. Pickering seemed highly unsatisfactory, Sir Andrew Clarke sent him back to Sungei Ujong at once with a letter to the Dato' Bandar, telling that chief that the Government recognized the Dato' Klana as the head of affairs, and the Dato' Bandar must submit to him or take the consequences. The old man's only reply was that he was quite satisfied with things as they were; would not submit to his rival; and that the affairs of Sungei Ujong were no concern of the Governor, who did not understand Malays and their customs. In fairness to the Dato' Bandar, it must be admitted that, by ancient custom, the Dato' Bandar was probably correct in his contention, but he had for years 
exceeded his authority, and treated the Dato' Klana as a young person to be kept in his place.

The Dato' Klana had provided himself with a small force of about forty Arabs, recruited in Singapore, and he was joined by some three hundred Malays of the country. Emboldened by these numbers and the presence of $\mathrm{Mr}$. Pickering and his Malacca police, under an English sergeant, the Klana determined to bring the Bandar to reason. The Klana and all his friends were, however, arrant cowards, and when the force took the field and was met by a determined resistance, the Malay warriors disappeared, guns were abandoned on the road, and $\mathrm{Mr}$. Pickering, Sergeant Kiernan, the Arabs and police were left to do all the fighting. They did it manfully; for though they were at first compelled to retire and their position threatened to become serious, they returned to the fray, retook lost positions, and drove the enemy from all his strongholds except Kapayang, the Dato' Bandar's own village. This place had been made very strong by a number of newly-erected defences, and the Bandar had secured the services of Raja Mahmud, of Sellangor, who was never so happy as when in command of a fight. Indeed, it was chiefly Raja Mahmud's name which had turned to water the blood of the local boasters, and, if the field had been left to the Malays, Raja Mahmud would have made short work of the Klana and his rabble.

The Governor had heard of Mr. Pickering's precarious position, and Colonel Dunlop was sent up with a relieving force of bluejackets and a few men of the Ioth Regiment. In the face of this display of strength, the Dato' Bandar abandoned his village and retired into Sellangor, Raja Mahmud holding the position just long enough to give the old man a fair chance of escape.

Sungei Ujong difficulties were thus brought to an end and as the Dato' Klana was now the undisputed ruler of the State, and sincerely anxious to do whatever he was 
told, a British Resident was sent to him, and the work of putting his house in order was begun in earnest.

As for the Dato' Bandar and Raja Mahmud, they made their way to the City of Festivals, where I met them, and after a deal of trouble persuaded them to let me take them to Singapore to see the Governor. I have good reason to remember Raja Mahmud as he walked into my dilapidated stockade at the head of a dozen men who, like their master, feared God, but had no sort of fear of man. I suppose he was under thirty years of age, of average height for a Malay, very well built, and extraordinarily alive. He had a fine open face, looked you straight and fearlessly in the eyes, and you realized that he always spoke the truth, because the consequences of doing so were beneath consideration. He was very smartly dressed, with silk trousers and a silk sârong, a fighting-jacket, a kerchief deftly and becomingly tied on his head, and in his belt the famous kris Kâpak Chinathe Chinese hatchet. His jacket attracted my attention most, for I had never seen one like it before, and, for that matter, have not seen another since. It had short sleeves to the elbow, fitted rather tightly to the body, and was made of a thick silk in narrow stripes of white and red, while over it in every direction were printed, in heavy black, texts from the Koran in the picturesque Arabic characters. I thought at the time how remarkably well this weird and fantastic jacket suited the man, his bearing and his reputation. It was only a visit of ceremony, but Raja Mahmud's strong personality, his straightforward manner, and his fearless courage attracted me immensely. We made fast friends, and though I took him to Singapore, and he accepted the Governor's order not to leave that place for twelve months, I also took him back to the Malay States, and in all the years which followed he never failed me, or any one else who understood him. Only he was not an everyday man: he was a type of the 
best quality of old Malaya, with all the Malay prejudices and hatred of innovation. One had to realize all this, to remember it, and to consider his view of life if you wished to see the best of him and earn his regard.

As for the old Dato' Bandar, he also went with me to Singapore, and gave himself up to the Governor's clemency. He was not allowed to return to Sungei Ujong, but was made comfortable with a house and allowance in Singapore, and there he died, as I have told in another book. ${ }^{1}$

It was in November, 1874, that a Proclamation was published, by Sir Andrew Clarke's directions, stating that the Secretary of State for the Colonies had approved all the arrangements made by the Governor with the Malay States, and warning all concerned that they would be held to the strict observance of their engagements. At the same time the following appointments were gazetted :-

Mr. James W. Birch, to be Resident of Pêrak, with Captain Speedy as Assistant Resident.

Mr. J. G. Davidson, to be Resident of Sělangor, with Mr. F. A. Swettenham as Assistant Resident.

Captain Tatham, R.A., to be Assistant Resident of Sungei Ujong.

Mr. Birch, the Colonial Secretary at Singapore, had been sent to Pêrak in October on special service, and when that duty was successfully discharged, he received the appointment of Resident, which he was most anxious to obtain.

Mr. J. G. Davidson, one of the leaders of the Singapore Bar, a close friend and consistent supporter of the Viceroy of Sĕlangor, and a man with strong sympathies for Malays, was selected as Resident of Sĕlangor.

Captain Tatham's appointment was temporary, and he

1 The Real Malay'. 
was shortly afterwards succeeded by Captain P. J. Murray, R.N., who held the post till his death in $\mathbf{I} 882$.

Thus each of the western States had been provided with a British Adviser, and to the uninitiated it might be supposed that everything would now go on satisfactorily. That, however, was the reverse of the case. 


\title{
CHAPTER IX
}

\author{
I $875-6$
}

SIR WILLIAM JERVOIS-BRITISH RESIDENT OF PERAK ASSASSINATED-PUNITIVE EXPEDITION

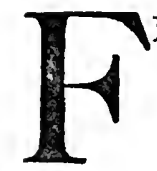

ROM the end of the year I874 till the following May, when Sir Andrew Clarke was translated to a post on the Council of the Viceroy of India, there is nothing particular to chronicle, but the reports from the Residents, especially from Pêrak and the Nine States, showed that there was a feeling of unrest, and that those whose profits and influence were threatened were not taking kindly to the new order of things.

Mr. Birch showed extraordinary energy in travelling about Pêrak, making the acquaintance of all the chiefs, and personally inquiring into the numberless complaints of the poor and oppressed. The peculiar circumstances of this State must be borne in mind. The quarrels of the Chinese had been stopped; they were again at work, the mines were doing well, order had succeeded chaos, and Lârut was on the high road to a prosperity exceeding anything ever known before. But the Mantri was secretly dissatisfied, his plans had miscarried; he could no longer collect and expend the revenues as he pleased, and instead of holding an almost independent position, he found himself in his proper place, with Abdullah, the recognized Sultan, but ill-disposed towards him. Then 
Abdullah, who had gained so much, was far from content. $\mathrm{He}$ was weak, inordinately vain, and hopelessly extravagant. The up-country people still declined to acknowledge him, and declared that Ismail, who had the regalia and refused to give it up, was their Sultan. Raja Yusuf, of course, sulked in his own lonely village, posing as the rightful claimant and threatening to invite the assistance of Siam, of Johore, of any one he could think of, to support a cause which he snew was hopeless so long as he was its sole advocate. The Assistant Resident in Lârut had a moderate force of Indians and Malays, and having only one man to deal with, the Mantri, he experienced no difficulty in collecting the revenue and seeing that it was properly expended. In the Pêrak Valley and the districts south of it the circumstances were widely different. Not only did the three Sultans essay to tax every one within their reach and every passer-by, but all the small chiefs did the same, and every sprig of nobility felt and said that this squeezing of the raiat and the Chinese was the only way in which a gentleman could condescend to make a living. As "the collection and control of all revenues and the general administration of the country" were, by the Pangkor engagement, to be regulated under the advice of the British Residents, it followed that Mr. Birch's determined efforts to carry out these provisions brought him into frequent and unpleasant conflict with all the influential people in the country. In the course of his wanderings Mr. Birch met with numerous cases of great oppression; poor people fined and even murdered for supposed offences, traders squeezed and robbed, and men, women, and children subjected to the infamous practice of debt-slavery. This custom, common to all Malay countries, consisted in the forcible detention of persons said to be indebted. Very often there was no real debt; the creditors invented one, or inflicted a fine for an offence never committed, and then compelled the reputed debtor, 
with his wife and family, to enter his service and treated them all as chattels. Of course the supposed debt was not paid, because, according to the creditor, it always kept increasing. Very often the original circumstances surrounding the claim were lost in the obscurity of past generations; the debt slaves were pǔsâka, an inheritance, like any other property. I will not harrow the reader by tales of the infamies committed under the cloak of this system; they can be imagined if it is understood that the creditor did what he liked with his debt slaves, and when they found life intolerable and ran away, if caught they were killed and no one objected, because every one of any position had debt slaves of their own. It is necessary to mention this custom, because its abolition created more trouble than any other question with which the Residents had to deal. It should also be added that if a free man or woman married a debt slave the free also entered into bondage, and the children of the marriage with them. Moreover, it was very common for a creditor to sell his debt slaves when he was tired of them or wanted money, and the bondspeople not infrequently suffered by the transfer.

This practice of debt-slavery was particularly rife in Pêrak, and as Mr. Birch determinedly set his face against it and helped several of the most oppressed to get out of the country, his action did not increase his popularity with the chiefs. Sultan Abdullah and the Lower Pêrak chiefs were amongst the worst offenders in this respect, and having gained the end for which they invited British assistance, they began to consider how they could get rid of the British Adviser, who interfered with their most cherished privileges, the collection of taxes, the power to fine and kill, and the institution of debt-slavery.

Raja Ismail and his adherents did not like the Resident, because they regarded him as a man brought in by their enemies, the Lower Pêrak chiefs, and also because he 
tried, unavailingly, to persuade Ismail to give up the regalia to Abdullah.

Raja Yusuf was dissatisfied because nothing was done for him; and the chiefs of every grade made common cause against a Resident who scoured the country, inquired into and pushed home their evil deeds, and endeavoured to put a stop to them. Therefore, some began to conspire to compass his death or removal, and others looked idly on, conscious of what was brewing, but not anxious to take a hand if they could avoid it. Only the poor and oppressed recognized and were grateful for all the many kindnesses they received from the Resident; for when he was not busy finding out all about the country and its resources, or writing instructions and suggestions for its development and administration, he was tending the sick, or giving generous help to those most in need of it. Unfortunately, he did not speak Malay, or understand the customs and prejudices of the people, and to this cause more than any other his death must be attributed.

In Sělangor matters went well enough. The State had a very small Malay population, and they were tired of fighting. The Viceroy was established in authority with a British Resident to help him. The rebellious action of the Sultan's sons was paralyzed by the presence of a British officer in their own village; Raja Mahmud had renounced the profession of a freelance; Raja Mahdi had also given himself up, and was dying of consumption in Singapore; while the Sultan was all for peace and freedom to give his undivided attention to his garden. So the Chinese flocked into Serlangor, and the development of mining promised shortly to put the State finances in a satisfactory condition.

Sungei Ujong made progress slowly; but the neighbours, the people of the eight other little States, who in their inland fastnesses had seen practically nothing of this new turn of affairs and heard news of the outer world but 
seldom, were far from content. So, when the Resident of Sungei Ujong pushed his travels beyond his borders, he was greeted by the same old tales of oppression, of squabbles for position and power, and he was warned, not always politely, to mind his own business and not come where he was not invited. That was well enough, and though, from motives of humanity he might have wished to interfere, he would not have been allowed to do so if his neighbours had not made a raid into Sungei Ujong.

That, however, came later. $U_{p}$ to the time of Sir Andrew Clarke's departure from the Straits there was no disturbance of the peace, but rumours of impending trouble reached him, and at the very moment when he and his successor, Sir W. F. D. Jervois, were together in Singapore messengers came from Sultan Abdullah full of complaints of the Resident and his interference with those very affairs to deal with which Abdullah had asked for his assistance.

Major-General Sir William Jervois was another officer of the Royal Engineers, the third in succession as Governor of the Straits Settlements, and he arrived at a moment when the affairs of the Malay States were to absorb all his attention.

It should be remarked in passing that the assistance rendered by Sir Andrew Clarke had cost a good deal of money, and it was fortunate that Governor Ord had left the colony with a large balance, for it was exhausted by his successors in carrying out the new policy towards the Malay States. I should, however, at once state that every farthing of this expenditure, and of future military expeditions, was eventually repaid by the Malay States on whose behalf it was incurred.

Sir William Jervois arrived in the end of May, 1875, and for the next four months devoted himself to the study of the Malay problem, as it was then developing. $\mathrm{He}$ received constant reports from the Residents, and those 
which came from Pêrak showed that affairs were becoming so strained that action of some kind would soon be a necessity. The Governor therefore decided to see what could be done by a personal interview with the chiefs. He went to Lârut, crossed over to the Pêrak River at Kuala Kangsar (the residence of the present Sultan of Pêrak), and made a progress down the Pêrak River, having interviews with Raja Yusuf and ex-Sultan Ismail, and continued his journey to Sultan Abdullah's village, where he joined his yacht and returned to Singapore.

In I874-5 I had made several visits to Pêrak to help Mr. Birch, and I was one of the party of about a dozen European officers who accompanied Sir William Jervois on this expedition. Mr. Birch and Mr. Davidson were also there, and it was explained to the Governor that the position of the Resident, as set out in the Pangkor Engagement, was untenable. Either the Resident, being alone and unsupported, must turn a deaf ear to all complaints, regard the terms of the Pangkor Engagement as a dead letter, and content himself with the impossible rôle of offering advice to those who paid no heed to it, or he must hold Sultan Abdullah and his adherents to the faithful discharge of those obligations which they had willingly undertaken, which the Secretary of State had approved, and the Proclamation of November, 1874, had warned them must be observed. It was evident that the Resident, if he met with direct refusal, or indirect obstruction which amounted to the same thing, could not threaten unless he had the means to enforce his words. Even if Abdullah and his party had shown any desire to be amenable, there would still have been serious trouble with Ismail and the up-country chiefs.

As the British Government had recognized Abdullah, clearly the first thing to do was to bring him to reason, and with this object Sir William Jervois and his party, attended by a guard of bluejackets, had a long interview 
with Abdullah and his chiefs at a place called Pasir Panjang, on the Pêrak River a few miles above Bandar Bhâru, the small island which $\mathrm{Mr}$. Birch had chosen for his station. That interview resulted in no satisfactory conclusion, but it was ascertained afterwards that Abdullah, realizing that his attitude towards the Resident had earned him the serious displeasure of the Governor, had arranged with a foreign Malay to amok the Governor's party at a given signal should an attempt be made to arrest and remove him. No such attempt was made, but Sir William Jervois decided to meet the difficulties of the situation by a new arrangement appointing British officers, as Queen's Commissioners instead of Residents, to carry on the administration of the country in the name of the Sultan. It was also arranged to have the necessary documents prepared and, when they were ready, to invite Abdullah to sign them, and if he refused to tell him that Raja Yusuf would, if he had the opportunity, be glad to accept the Governor's advice and give effect to it. It had been ascertained that both Raja Yusuf and Raja Idris (Abdullah's cousin and a man of exceptional ability) were agreed that the existing state of affairs could not continue, and they were ready to abide by the Governor's decision.

I remained in Pêrak for a fortnight after the departure of the Governor and his party to help the Resident to explain the new proposals to the Sultan and endeavour to secure his acceptance of them. The result of several long interviews with Abdullah-interviews wherein he showed himself most impracticable-was to decide him to sign the documents accepting and announcing the new policy, and with these I left at once for Singapore. Before I left, Mr. Birch had been told by some of those whom he had befriended that there was a plot to kill him, but to this he paid no attention as the story was not new. 
After a very short stay in Singapore, I returned to Pêrak with the proclamations necessary to give effect to the new arrangement and handed them over to Mr. Birch at Bandar Bhâru. I found him suffering from a sprained ankle and only able to walk with the help of crutches. Lieutenant Abbott, R.N., and four bluejackets were with him, and, on the night of my arrival, the native sergeantmajor of Mr. Birch's Indian guard (about eighty Pathans, Sikhs, and Punjabis) behaved so badly that he had to be confined in the guard-room, while his men were in a state bordering on mutiny. It was then arranged that I should go up river to a village called Kota Lama, above Kuala Kangsar, a village with the worst repute in Pêrak, and distribute the proclamations in the Upper Country, returning about the 3 rd November to meet Mr. Birch at Pâsir Sâlak, the village of the Maharaja Lela, five miles above Bandar Bhâru. Mr. Birch, meanwhile, was to go down river and distribute the proclamations amongst Abdullah's adherents, where no trouble was expected, and we were to join forces at Pâsir Sâlak because the Maharaja Lela was believed to have declared that he would not take instructions from the Resident, and it was known that he had built himself a new house and had recently been protecting it by a strong earthwork and palisade. Therefore, if there was to be trouble it would probably be there. What was only disclosed long afterwards was that, as soon as he had consented to the new arrangement, Abdullah summoned his chiefs (including the Maharaja Lela and the Dato' Sâgor, who lived at Kampong Gâjah on the opposite bank of the river to Pâsir Sâlak) and told them that he had handed over the government of the country to Mr. Birch. The Maharaja Lela, however, said that he would not accept any orders from the Resident, and if Mr. Birch came to his Kampong he would kill him. Asked whether he really intended to keep his word, he replied that he certainly meant it. The Dato' Sâgor also 
said that he was of one mind with the Maharaja Lela. The meeting then broke up and the members returned to their own villages. Later, when the proclamations arrived, the Sultan again sent for the chiefs, showed them the papers, and asked what they thought of them. The Laksamâna said, "Down here, in the lower part of the river, we must accept them." But the Maharaja Lela said, "In my Kampong, I will not allow any white man to post these proclamations. If they insist, there will certainly be a fight." To this the Sultan and the other chiefs said, "Very well." The Maharaja Lela immediately left and, having loaded his boats with rice, returned up river to his own Kampong.

I left Bandar Bhâru at noon, on 28 October, with two boats, my companions being Raja Mahmud of Sellangor and two of his men whom I had brought with me from Singapore, a Manila boatman of tried courage, and a Chinese servant. As I went up stream Mr. Birch was starting to go down, and when last I saw him he was lecturing the Sikh sergeant-major, who had been released after his night in the guard-room. On my way up river I called at Blanja, ex-Sultan Ismail's village, but failed to see him. I left a number of proclamations there, after explaining them, and went on to Raja Yusuf, who assured me that no good could ever be done until there had been a fight. The further I went the more threatening became the talk, and every one was full of gossip of the dreadful things that were going to take place. This, however, was rather the custom of the country, and we did not pay too much attention to it. By great exertions we reached Kuala Kangsar on the night of 3 I October, and on I November I posted the proclamations in that village. On the 2nd I crossed the river, interviewed the Raja Běndahâra, read the proclamation to him, and gave him copies which I asked him to post. The next day I distributed the proclamation in a number of inland villages, 


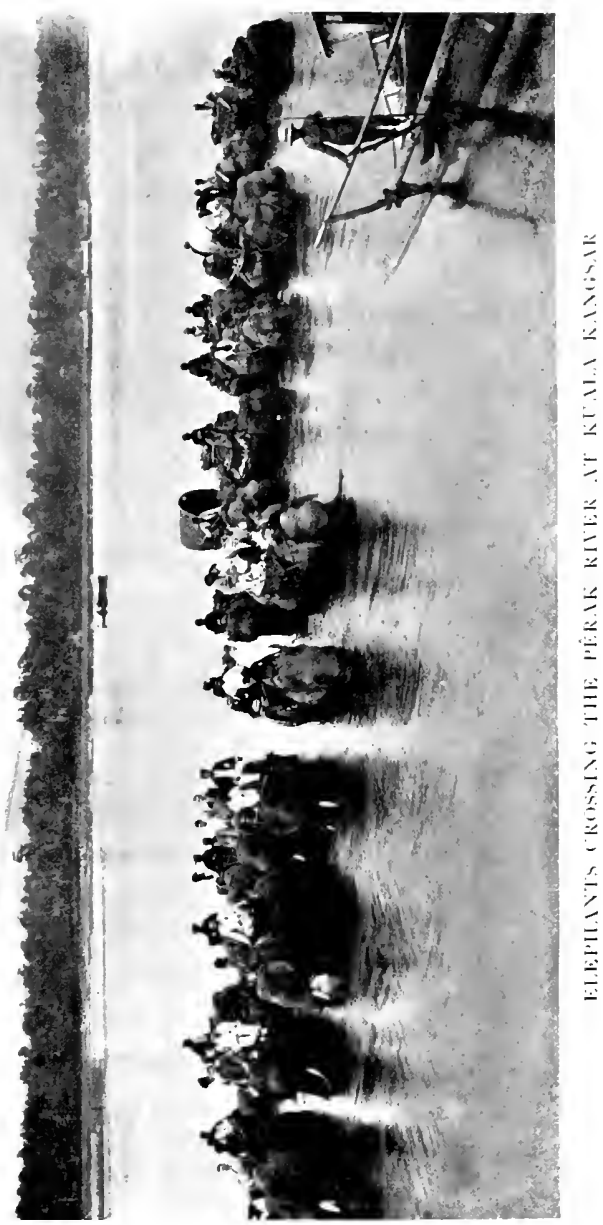



and in the afternoon went to Kota Lâma, where I had a somewhat stormy interview with some of the truculent spirits of that very independent village; but we managed to part civilly. On 4 November, my work being done, I started down river at 8.30 a.m. intending to spend the night at Blanja. We reached that place about 4 p.m. and found there a very large collection of boats and men. As we were dragging our boats through the shallow water towards the shore, one of Ismail's most trusted scoundrels waded out to tell us that Mr. Birch had been killed by the Maharaja Lela's people, at Pâsir Sâlak, on 2 November; that Bandar Bhâru had also been taken and the Indian guard killed or dispersed; and that the river had been staked right across, at Pâsir Sâlak, to catch my boats as we returned. When I asked how they knew all this, the messenger said the Maharaja Lela had sent a letter to ex-Sultan Ismail to tell him what he had done, and, to prove the truth of his story, he had dispatched it by Mr. Birch's own boat, which had returned down stream only about two hours earlier. The messenger then invited us to land, as there was nothing to gain by an impossible attempt to pass through the lower country, which was now in arms and on the watch for us.

We made an excuse to get rid of him, and Raja Mahmud at once said that to land would be suicide. We could not stay where we were, we had no inclination to turn back, and there was small inducement to do so. As the Pêrak boatmen did not wish to take the risks, I decided to leave them behind, and continue our journey down stream in one boat. When the messenger returned to usher us ashore, we were just pushing the boat out into the stream, and though he tried to dissuade us and told us we were going to perdition, his words helped to convince us that we had made the right choice. He was still standing in the river, above his knees in water, when we were slipping down at a great rate on a strong current. 
All the Residency boats were painted white, and we had one of them, so there could be no pretence at concealment, and for that reason we did not trouble to remove the British ensign which was flying at the stern. For crew we had three foreign Malays and Raja Mahmud's two followers; for coxswain, the Manila man; Mahmud, myself and the Chinese servant were the passengers. The men had already done nearly eight hours' work on one meal, there were about sixty miles of difficult river between us and the zone of greatest danger, and no time to stop for cooking. We calculated that, if we paddled strenuously all night, we should reach the barrier about 9 a.m., for no house boat had ever made the journey in anything like twelve hours. Just as night was falling we passed $\mathrm{Mr}$. Birch's "Dragon" boat, on a sandspit by a large village, and that removed from our minds all doubt as to his fate. By a series of fortuitous circumstances, and to our own immense surprise, we reached the Maharaja Lela's village at I a.m. and passed it safely, for there was no barrier. As usual with Malays, they had meant to build it, but they did not expect us so soon, and probably thought that, if we came at all, they would have due warning. Both banks were lined with large watch fires and groups of armed men, and though we ran into the bank exactly under one of these groups and were duly challenged, we got off again without being recognized.

The Eastern very rarely expresses astonishment, but here was an exception, for to all of us it was not the unexpected, but the impossible which had happened. We crept past Bandar Bhâru, Mr. Birch's station, in the belief that it was in the hands of the enemy, but that statement was also incorrect, and made our journey ten miles longer than it need have been.

Afterwards we learned that ex-Sultan Ismail sent from Blanja two boat-loads of braves to follow us and do on the river what they had no doubt hoped to have the oppor- 
tunity of accomplishing on shore, when the plan miscarried by reason of our sudden disappearance down stream. The pursuers must have lagged by the way, for we saw nothing of them.

At daylight the next morning we returned up river to Bandar Bhâru, and there and afterwards heard the details of Mr. Birch's assassination.

He had done his work in the low country more quickly than he expected, and reached Pâsir Sâlak at midnight on I November with three boats containing the Resident, Lieutenant Abbott, R.N., a guard of twelve Sikhs, an orderly, a Malay interpreter, and a number of boatmen. In all the party numbered about forty men, and they had plenty of arms and ammunition. They anchored in midstream for the night, and at daylight hauled to the bank, when Mr. Abbott crossed to the other side of the river to shoot snipe, and Mr. Birch sent a message to the Maharaja Lela to say that he would be glad to see him, either at the boats or in his own house. To the interpreter who carried the message the chief said, "I have nothing to do with Mr. Birch."

Some days earlier, the Maharaja Lela had summoned all his people and told them that Mr. Birch would shortly come to Pâsir Sâlak, and if he attempted to post any notices there the orders of the Sultan and the down-river chiefs were that he should be killed. The people replied that if those were the orders they would carry them out, and the Maharaja Lela then handed his sword to a man called Pandak Indut, his father-in-law, and told the people to take Pandak Indut's directions as though they were his own. Directly Mr. Birch arrived messengers were sent out to collect the people, and, before the sun was hot, there were already about seventy armed men on the bank above Mr. Birch's boats. The Dato' Sâgor had come over from the other side (in the boat which had taken Mr. Abbott across) and he had seen and spoken to Mr. Birch, 
and was now with the Maharaja Lela. By Mr. Birch's orders the interpreter posted a proclamation on the shop of a Chinese goldsmith, close to the bank, and this paper was torn down by Pandak Indut and taken to the Maharaja Lela, the occurrence being at the same time reported to Mr. Birch. The crowd on the bank were showing distinct signs of restiveness; but the boatmen began to make fires to cook rice, and Mr. Birch went to take his bath in a floating bath-house by the river bank, his Sikh orderly standing at the door with a loaded revolver. The interpreter was putting up another copy of the proclamation when Panduk Indut tore it down, and as the interpreter remonstrated, Pandak Indut thrust a spear into him and cried out, "Amok! âmok!" The crowd instantly rushed for the bath-house, and attacked the boatmen, and any of the Resident's party within reach. Spears were thrust through the bath-house, and Mr. Birch sank into the river, coming to the surface just below the bath-house, when he was immediately slashed on the head with a sword and was not seen again. Mr. Birch's Sikh orderly had jumped into the river when the first rush was made at the bath-house, and he swam to a boat, taking great care to save the revolver, which he had not fired, from getting wet! The interpreter struggled to the river, and was helped into a boat by two of $\mathrm{Mr}$. Birch's Malays, but he died very shortly afterwards. A Sikh and a Malay boatman were also killed and several of the others were wounded; but the rest with great difficulty got away. Mr. Abbott, on the other bank, was warned of what had occurred, and managed to get a dugout and escape, running the fire from both banks.

Then the Maharaja Lela came out and asked who were those who had actually had a hand in the killing. Pandak Indut and the others at once claimed credit for the deed, and the chief ordered that only those who had struck blows should share in the spoils. Then he said, 
"Go and tell the Laksâmana I have killed Mr. Birch." The message was duly delivered, and the Laksâmana said, "Very well, I will inform the Sultan." The same evening the Maharaja Lela sent Mr. Birch's boat to Blanja, with the letter to ex-Sultan Ismail describing what he had done. Ismail was much too clever to keep the boat, so he sent it back again. All the arms and other property were removed to the Maharaja Lela's house, and orders were given to build stockades, to stake the river, and to amok the Resident's station at Bandar Bhâru. The party sent on this last errand returned without accomplishing their object; for when they got near the place it began to [rain, and the people in the house where they took shelter told them that they would get a warm reception at Bandar Bhâru, and it would be quite a different thing to murdering the Resident.

By the help of a friendly Malay, a foreigner, Mr. Birch's body was recovered and buried at Bandar Bhâru, on 6 November. ${ }^{1}$

I arrived at Bandar Bhâru on 5 November, and there was plenty to do, attending to the wounded, strengthening the place, and heartening the rather demoralized garrison of Indians. The position was also difficult, in that it was impossible to tell which, if any, of the Lower Pêrak chiefs were friends. The Sultan sent a message with offers of assistance, but we thought it best to send a polite refusal. On the 6th, Captain Innes, R.E., arrived from Pinang with two officers and sixty men of the r/Ioth Regiment, and the Honourable $H$. Plunket with twenty Pinang police. We already had Lieutenant Abbott and his four bluejackets, and about fifty so-called Sikhs, besides Raja Mahmud and a Sumatran, named Nakodah Orlong, with about fifteen followers, who volunteered their services. With this force we started at 4.30 a.m. the next morning to attack Pâsir Sâlak, but, for various reasons, principally

1 This and other incidents are described in greater detail in Malay Sketches. 
because no gun was taken, the attack failed. The Pinang police, in spite of Mr. Plunket's strenuous efforts, retired as soon as we came in touch with the enemy, and the Sikhs a little later, and, in trying to take a strong stockade, Captain Innes and Nakodah Orlong were killed; both the I/Ioth officers were severely wounded and there were a number of other casualties. A week later, with re-inforcements and a naval brigade, the whole position was successfully carried without loss on our side. The villages of the Maharaja Lela and the Dato' Sâgor were burned, and I had the satisfaction of recovering from the Maharaja Lela's house my dispatch-box, which had formed part of the plunder of Mr. Birch's Dragon boat.

The assassination of the Resident of Pêrak, and rumours of trouble in Sĕlangor and the Nine States, gave such a serious turn to affairs that assistance was requested, both from Hong Kong and India. In the course of the next few weeks the following troops, under Major-General the Honourable F. Colborne, C.B. (from Hong Kong), and Brigadier-General John Ross (from India), were collected at the scene of disturbance: 300 officers and men of H.M.'s 8oth Regiment, 200 officers and men of H.M.'s I/Ioth Regiment, a battery and a half of Royal Artillery, H.M.'s 3rd Regiment (the Buffs), about 600 strong, the Ist Goorkhas, 450 strong, and one company of Bengal sappers, numbering 80 men.

These troops were greatly assisted by a Naval Brigade drawn from H.M.'s ships Modeste, Thistle, Philomel, Ringdove, and Fly.

Major-General Colborne and the troops from China made their head-quarters at Bandar Bhâru, while the Indian contingent, under Brigadier-General Ross, were stationed at Kuala Kangsar.

After the capture of Pâsir Sâlak and Kampong Gâjah, the Maharaja Lela, the Dato' Sâgor, and their people retired up river to Blanja, joined ex-Sultan Ismail, and the 
main body then established themselves at a small town called Pěngkâlen Pigu, on the Kinta River, fifteen miles inland from the left bank of the Pêrak River.

Major-General Colborne then organized an expedition to follow and dislodge the fugitives. The main difficulty was transport, for, as there were no roads, the whole force had to be sent up river by boats. Blanja was reached on I3 December, and after a very trying march of three days through the jungle, taking several stockades on the way, and suffering some loss, Pĕngkâlen Pigu was occupied on 17 December. The Malays abandoned the place after a slight resistance, and retreated north until they eventually crossed the frontier and got into Kĕdah territory.

Brigadier-General Ross's force was to have co-operated in this movement, but, owing to the transport difficulty, they failed to appear till long after the end was accomplished. Meanwhile they had several affairs of their own at the village of Kota Lama, where our troops met with some loss, but eventually put down all opposition.

A certain number of the troops remained quartered in strategic positions in Pêrak for about eighteen months, after which they were withdrawn and their places taken by a force of armed police. In the early part of that period ex-Sultan Ismail and his followers were so persistently hunted by various parties of irregulars that at last they gave themselves up to the Sultan of Kĕdah, who handed them over to the Lieutenant-Governor of Pinang on 20 March, I876. Thus the Pêrak regalia, to which Ismail had clung so tenaciously, found its way into the Singapore treasury, and was stored there for several years, until it was transferred to the keeping of the present Sultan of Pêrak. The ex-Sultan, Ismail, was allowed to reside in Johore, where he died in 1889.

Whilst these events, so briefly described, were taking place in Pêrak, affairs had come to a crisis in the Nine States. 
Near the end of November, 1875, a survey party, despatched from Sungei Ujong across the border into Terâchi, was stopped, and when the escort came up they were fired upon. The party retired, but the Malays collected a considerable force, invaded Sungei Ujong territory, and established themselves in some mines at a place called Paroê, not many miles from the Residency. There were then stationed in Sungei Ujong a few men of the I/roth Regiment, and these being reinforced and supported by some police and a native contingent of about eighty men, attacked the Malay defences, suffered considerable loss, and failed to force them until the arrival of a gun, which soon settled matters. The Malays were driven out, and retired to a very strong position in a narrow defile in the range of hills dividing Sungei Ujong from Terâchi. Before attacking this place-Bukit Putus by name-considerable reinforcements of Royal Artillery, Goorkhas, and Naval Brigade were dispatched to Sungei Ujong, and the defile was eventually carried on 20 December by the courageous action of Captain Channer, of the Goorkhas, who had gone forward scouting with a few men, and, seeing his opportunity, rushed a stockade which commanded the rest of the position. Captain Channer was awarded the Victoria Cross for this gallant action. The Malays, driven over the border without further loss to us, were completely demoralized, and gave no further trouble.

When the military operations in Pêrak were concluded, I was called to Singapore to be Secretary for Malay Affairs. Mr. J. G. Davidson, of Sělangor, succeeded Mr. Birch as Resident of Pêrak, and Captain Blomfield Douglas was appointed Resident of Sĕlangor.

Commissioners had been appointed to inquire into all the circumstances which led up to the assassination of $\mathrm{Mr}$. Birch, and the evidence they collected was of such a character as to prove the complicity of Sultan Abdullah the Mantri, the Dato' Laksâmana, and the Dato' Shaban- 


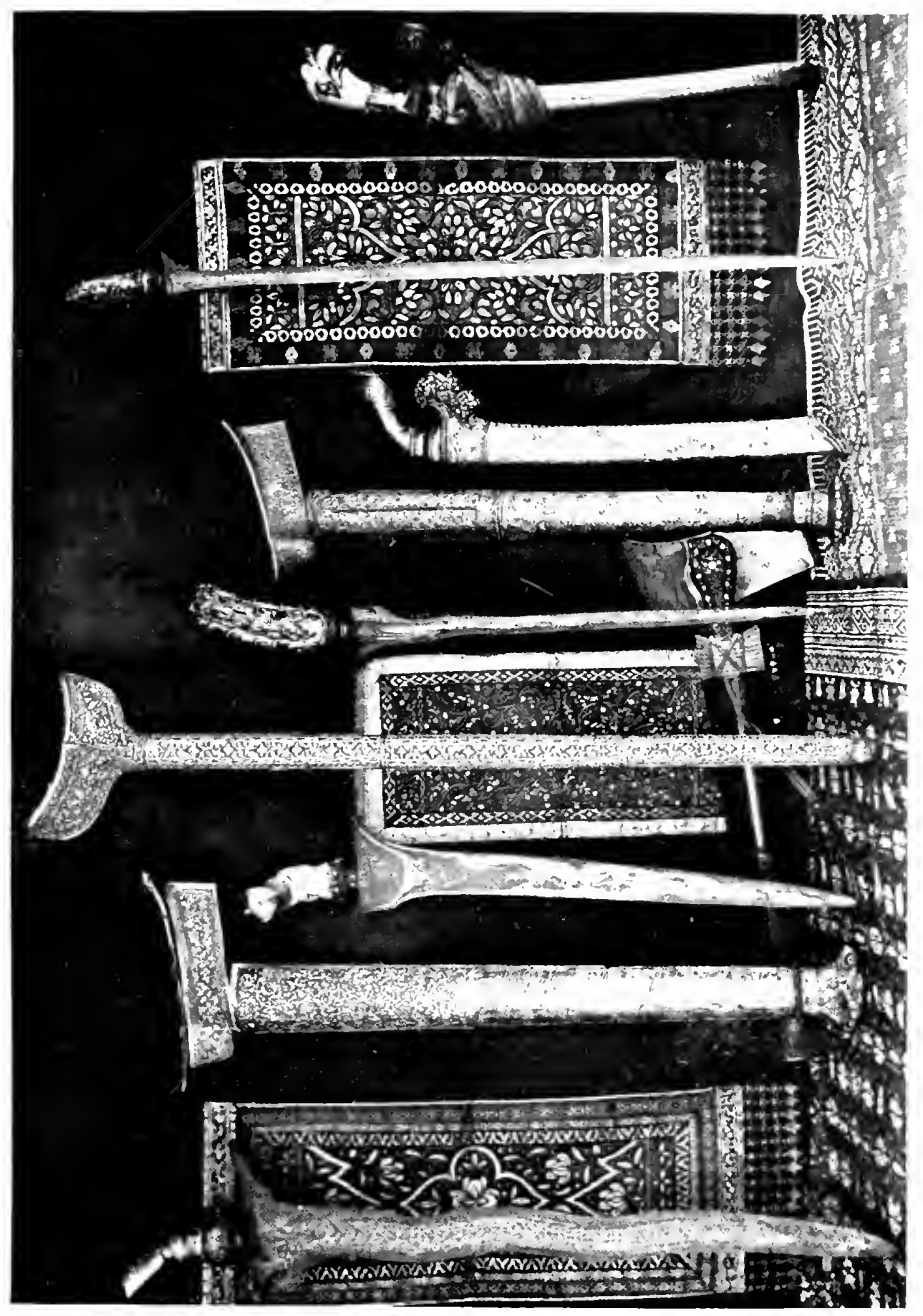



dar. These persons were therefore removed to Singapore, and after a long residence there, during which the case was gone into most thoroughly, they were severally deported to the Seychelles.

The Maharaja Lela, Pandak Indut, and others, wearied by months of wandering in the jungles of Upper Pêrak, came south in July, I876, and gave themselves up to emissaries from the Maharaja of Johore on the sole condition that they should receive a fair trial. They were conveyed to Johore, from thence to Singapore, and finally to Larut, where they and the Dato' Sâgor, who had already been secured, were charged with the murder of the Resident, his interpreter, and two of his people. The accused were tried in December, I875, before Raja Yusuf and Raja Husein, with Mr. Davidson and Mr. W. E. Maxwell as British assessors. Colonel Dunlop and I prosecuted for the Government, and the prisoners were defended by an able member of the Singapore Bar, Mr. J. D. Vaughan. After a trial which lasted seven days all the accused were found guilty. The Maharaja Lela, the Dato' Sagor, and Pandak Indut were executed, but in the case of all the others the sentence was commuted to imprisonment for life. One man had already been tried and executed, another had died in the jungle, and, so far as is known, every one directly or indirectly concerned in the crime was brought to justice. The village of Pâsir Sâlak was destroyed and not allowed to be reoccupied.

These measures were then very necessary if they sound severe now; but Malays did not question the justice of them, and considering the circumstances they cannot really be regarded as harsh. Neither the Maharaja Lela, the Dato' Sagor, nor any of their people had any grievance against the Resident. He represented ideas of right and wrong with which they had no sympathy and a foreign Power beyond their ken, against whose interference in Malay affairs they instinctively rebelled. Therefore they 
determined to kill him, believing that that would be the end of the matter. All warnings that the British Government would carry its policy through they treated with contempt, for they disbelieved them; and never having seen white men in the State before, Malays laughed at the idea of white troops ever penetrating its jungle fastnesses. To get rid of the one or two who knew the country seemed to them all that was wanted, and then they would be left alone, as they had been since the beginning of time. They took on themselves a responsibility which they paid for with their lives, and when their own Rajas passed sentence they told the Maharaja Lela and his fellows that they were guilty not only of murder, but of treason; for while Sultan Abdullah and many responsible chiefs, including the Dato' Sagor, had asked for British help and a British officer, the accused had taken upon themselves to assassinate their country's invited guest.

Of the complicity of Sultan Abdullah and the rest, there was proof enough and to spare. They had guilty knowledge of and acquiesced in the intended murder; banishment and loss of position were not too heavy a penalty for conniving at a crime which it was their bounden duty to prevent. During banishment they were accompanied by their families and granted allowances for their support. After a number of years in the Seychelles, and when peace and order had been firmly established throughout the western States, Abdullah and the others were permitted to return to Singapore. The Mantri, the Laksâmana, and the Shabandar died years ago, but Abdullah is still in Singapore, where he receives a generous allowance from the Pêrak Government, and is free to do as he pleases.

After the flight of ex-Sultan Ismail, the removal of Sultan Abdullah, and the disclosure of all the circumstances surrounding the death of Mr. Birch, the British Government recognized Raja Yusuf as Regent, and later 
as Sultan of Pêrak. Though his hereditary claim was, as has already been stated, better than that of Abdullah, he would probably never have become Sultan without the support of the British Government.

Mr. Davidson, the new Resident of Pêrak, and Captain Speedy, the Assistant Resident, resigned their posts in I 876-7, and were succeeded by Mr. Low, afterwards Sir Hugh Low, G.C.M.G., and Mr. W. E. Maxwell, afterwards Sir William Maxwell, K.C.M.G.

Sir William Jervois left the Straits in the spring of I 877 to report on the defences of Australia, and remained there, being appointed Governor of South Australia.

Sir William's action in Pêrak was not approved by the Secretary of State for the Colonies, and a long and somewhat bitter correspondence ensued between them. The Governor's main contention was that the situation was impossible, and he took a step in advance of the policy adopted by Sir Andrew Clarke, feeling satisfied that it would meet with the same approval. The Secretary of State's reply was that no new policy of such importance ought to have been initiated without first consulting him, at least by telegram, that a longer trial should have been given to the system so lately introduced, and that there were no grounds to lead the Governor to assume that his new departure would be sanctioned.

Even now it is a little difficult to judge fairly between these two views, though it is not easy to acquit Sir William Jervois of precipitancy, or at any rate of neglecting to use the cable. His excuse was that the need for action was urgent, and he could not have explained the situation within the compass of any reasonable telegram.

Setting aside all personal feelings, and these counted for something at the time, it is very certain that no "system" had ever been conceived. There was an idea and that was all. The idea was that a British officer, or two, should be sent into a country where white men were 
unknown; where everything that could be wrong was wrong; where almost every man was a law to himself; where there was hardly any trade, no development of any kind, no roads, no police, or other means of maintaining order; and where two or three individuals claimed to be supreme. It was apparently supposed that, under these circumstances, the single white man would reduce everything to order by the exercise of tactful advice. The greatness of the implied compliment did not reduce the difficulties of a task which was only possible when the native ruler was prepared to accept the advice offered him, and had authority to enforce his own commands. In Pêrak this was not the case; in fact, it could not be so while there were several claimants to the throne; but when, in addition to that patent fact, the Resident had to deal with a Sultan and chiefs who declined to accept almost any advice, the position was quite hopeless.

Sir William Jervois's policy met with disaster at its very inception, and that was enough to discredit it. But, if no attempt had been made on the life of the Resident, it is difficult to see how any progress could have been made, until the Queen's Commissioners were supported by a force strong enough to give effect to their orders.

In Sĕlangor the trouble only ceased when all the Viceroy's enemies had been removed, after years of fighting. In Sungei Ujong the Dato' Klana was helpless till his rival had been driven out of the State, and practically interned at Singapore. The conditions in Pêrak were infinitely more difficult, in proportion as the State was three or four times as large, with eight or ten times as many Malay inhabitants, and twenty or thirty times as many Rajas and chiefs with all sorts of real and fancied vested interests.

Raja Yusuf, unpopular as he was, knew his country and his people probably better than any one, and he was right when he said that no real good could ever be done till 
those who most wanted it had been taught a lesson. Intimately associated with all the details from the beginning, I am convinced that twenly years of advice-could it ever have continued so long-would not have accomplished, for peace and order and good government, what was done in six months by force of arms. Mr. Birch did not die in vain; his death freed the country from an abominable thraldom, and was indirectly the means of bringing independence, justice, and comfort to tens of thousands of sorely oppressed people.

In Pêrak at any rate things had reached an impasse; Sir William Jervois tried to relieve the situation, and his action had the desired result; though the means by which it was attained were as far from those he had devised as the end was better than any which his proposal could have secured. Therefore his name deserves to be remembered in connexion with this curious experiment in administration.

Even then, however, after the removal of the most dangerous elements of discord, the most active opponents of reform, there was no "system" to guide the Residents in their difficult task. 


\section{CHAPTER $\mathrm{X}$}

THE EVOLUTION OF THE RESIDENTIAL SYSTEM-TIN MINING-WHAT THE MALAY STATES OWE TO CHINESE LABOUR AND ENTERPRISE-ROADS-RAILWAYS

7 HE long correspondence between Sir William Jervois and the Secretary of State for the Colonies was concluded by a despatch dated

i. I June, 1876, in which Lord Carnarvon laid down the future policy of H.M.'s Government towards the Malay States. This despatch embodied the only detailed instructions ever issued by the Colonial Office in regard to the functions of the British Residents, and the following are the most important paragraphs:-

"I need not, however, delay longer to say that on a general review of the correspondence which has come before me, I fail to see any proof that the system under which Residents were appointed to the Native States has had such a trial as to justify me in pronouncing that it has failed, or that any other course which has been indicated is not open to graver risk, larger expenditure, and more doubtful results. The obstacles which have interfered with its success are apparently such as can be removed."

On receipt of this despatch in Singapore, copies were forwarded to each of the Residents with a covering letter, which contained these passages :-

"You will observe that in continuing the Residential system, Her Majesty's Government define the functions of the Resident to be the giving influential and responsible 
advice to the ruler, a position the duties of which are well understood in the East.

"The Residents are not to interfere more frequently or to greater extent than is necessary with the minor details of government; but their special objects should be, the maintenance of peace and law, the initiation of a sound system of taxation, with the consequent development of the resources of the country, and the supervision of the collection of the revenue, so as to ensure the receipt of funds necessary to carry out the principal engagements of the Government, and to pay for the cost of the British officers, and whatever establishments may be necessary to support them."

It must be again noted that Lord Carnarvon, after months of correspondence, finally refused to sanction the proposals of Sir William Jervois, but still wrote of the "system " under which Residents were appointed ; whereas nothing with any pretensions to a system had ever been formulated. That was all to come, and to be worked out by the Residents themselves in their efforts to act up to the peremptory instructions contained in Lord Carnarvon's despatch of I June, I876, and repeated in the covering letter just quoted.

For one white man to maintain the law-something unwritten and unknown-and preserve the peace in a foreign State of which he knew very little, initiate a sound system of taxation and get it observed, develop the resources of the country, supervise the collection of revenue so as to provide means to meet all the costs of administration, and yet "not interfere more frequently or to a greater extent than is necessary with the minor details of government" was surely an impossible task.

A couple of years later a Resident was held to have exceeded his authority, and he and his colleagues were again reminded of Lord Carnarvon's instructions, with this additional and solemn warning: "The Residents have 
been placed in the Native States as advisers, not as rulers, and if they take upon themselves to disregard this principle, they will most assuredly be held responsible if trouble springs out of their neglect of it." The matter was reported to the Colonial Office, and Sir Michael Hicks-Beach, then Secretary of State, wrote: "I fully recognize the delicacy of the task imposed on the Residents, and am aware that much must be left to their discretion on occasions when prompt and firm action is called for.

"The letter which was addressed to the Residents by your advice on 17 May appears to be both necessary and judicious in the terms, and I am glad to be able to add that I feel that I can rely on your keeping a watchful eye on the proceedings of the Residents and taking care that they do not exceed their proper functions."

The Colonial Office said the Malay States were to be wheeled into line, everything was to be done on the most approved principles, and one white man was to do it, but the means to secure this very desirable end were not mentioned; only the Resident was not to carry his interference too frequently into the minor details of government. Then the Governor was determined that he would bear no responsibility for any trouble that might arise, so he warned the Residents that they were in the Malay States to give advice only, and if they did more than that, it would be at their peril. Another Secretary of State approved this warning, and there the matter ended.

It seems to have been supposed by the highest authorities in Downing Street and Singapore, that the "passive resistance " of tens of thousands of Malays could be successfully met by the "peaceful persuasion" of two or three Residents, but thirty years later it is recognized that, even in England, "peaceful persuasion" is only effective when the persuaders largely outnumber the passive resisters. When the conditions are reversed the results are negative, and it 
is too much to expect that one white Christian will be able to impose his will upon a Muhammadan people who have never had any experience of Europeans and never known any outside interference. To the Malay the situation was obvious, and in the silence of the night he more than once explained to me that I and the other Residents were thrown out as bait by the British Government. If the Malay chiefs swallowed the bait, they would find themselves on the British hook; of course no one would worry about the bait.

It is absolutely necessary that these facts should be thoroughly understood, if a correct judgment is to be formed of the means by which this very novel experiment in administration was to be carried to a successful issue.

When the first Residents were appointed, in 1874 , they spent most of their time travelling about the country, and when they had anything to say, they reported it to the Governor, through the Secretariat in Singapore. Lârut and Sĕlangor were not affected by the subsequent disturbances, and, therefore, those places were the first to feel the effect of the British Adviser's presence. In Lârut Captain Speedy's Indians became the nucleus of a police force, and, as the Chinese were only anxious to get to work again, and there were hardly any Malays in the district, the Assistant Resident was able at once to open a treasury, organize a customs service, establish a court where he sat as magistrate, create a Land and Survey Office, and to begin, in a small way, to get together a staff of European and native officers to assist him in evolving order out of chaos. No doubt he consulted the local chief, the Mantri, in all matters of importance, but he received no help from that quarter, and simply pushed on alone when he could not carry the Mantri with him. A mining population could not be dealt with by either a divided authority or indefinite procrastination, and as Lârut at once started on the road to prosperity, and the 
Chinese interest enormously outweighed every other, no one had anything to say, and people of all nationalities united to give a helping hand. Whilst the rest of Pêrak was standing absolutely still, Lârut was already forging ahead, and when the assassination of the Resident came, and the subsequent military expedition, this district was practically unaffected. Even the removal of the Mantri for his complicity in Mr. Birch's murder aroused only a passing interest.

In Sělangor, the Viceroy and the Resident (Mr. Davidson) were old friends, and the latter was able to establish a Government Treasury with a proper system of accounts, to organize a police force, and initiate such simple reforms as were required in a small place like Klang. Owing to the distance and the absence of any kind of road, the Captain China was allowed to continue his benevolent despotism over his countrymen in and around Kuala Lumpor and the mines.

In Sungei Ujong, once the Klana reigned alone, his anxiety was to have everything done in accordance with English methods; so the Assistant Resident had no trouble in introducing the rudiments of government, including a police force, a magistrate's court and a prison, a treasury, and the collection of all revenue in the name of the State. The subsequent disturbances, and the temporary military occupation of Sungei Ujong and the neighbouring States, delayed their advancement, but a new and better start was made in 1876 when these troubles were over, and Sir William Jervois, before he left the colony, was able to bring six of the nine States together again, and their chiefs made an agreement electing Tunku Antar as their head, with the title of Yam Tuan of Sri Menanti. Sungei Ujong, Rĕmbau, and Jĕlěbu, declined to join, and they were recognized as being outside and independent of this arrangement. Since then, however, all these small States have happily 
settled their differences and made another treaty acknowledging Tunku Muhammad, C.M.G., the successor of Tunku Antar, to be their Raja with the title of Yang di Pertuan of Nĕgri Sambîlan.

The ground having been cleared, the Residents were able to push on their work under much more favourable conditions than they had previously enjoyed. The most obstructive chiefs had been removed, the long arm of England was no longer a myth, some posts were still occupied by British troops, and those Malays who formerly had ignored or openly defied all forms of advice were now inclined to do nothing worse than show their objection to the interference of Europeans by sulking and indirectly thwarting the wishes of the Government. This attitude only gave trouble in Pêrak, where the Malay population was much larger, and the people much more difficult to deal with, than in either of the other States. The period of "passive resistance" was eventually overcome by infinite patience and consistent firmness, so that in the end the ever-decreasing band of irreconcilables found themselves without either sympathy or support, and with no valid ground of complaint.

It will be understood that even from the first the Residents had exercised, or tried to exercise, an influence which could not be truthfully defined as the simple offer of advice, and when, in 1878 , they were warned that if they departed from the rôle of advisers they would be held answerable for any trouble which might occur, they accepted the responsibility as preferable to a position of impotence and an attitude which no native in the country could have either understood or appreciated.

The first thing to be done was to organize a reliable police force, and the States were fortunate in securing the services of able and energetic officers, assisted by a number of excellent non-commissioned officers obtained from the British forces stationed in the colony. 
Under Malay rule it had been the custom to levy duties on every article imported into, or exported from, the States, and the net result of this policy was a revenue which, in I874, could not have amounted to $\$ 400,000$ for all the three States, though, of course, there were no means of ascertaining the exact figures. All the most vexatious imposts were abolished, and the sources of revenue were confined to an import duty on opium and spirits, a farm of the sole right to open, in specified places, public gambling-houses for Chinese, and to license the opening of pawn-shops. The import duty on tobacco was continued, but this was abolished after a short time. The main source of revenue was an export duty on tin (a very high duty, but yet lower than that previously charged), and a Io per cent ad valorem duty on all jungle produce and the export of salt fish. The last was abolished later. Internal revenue made a small contribution for the sale of land, and an annual quit rent on all land granted for building and agricultural purposes; for the fines and fees of the courts; for the issue of fishing and other licences, and so on. The revenue collected in each of the three States in 1875 , the first completed year of the new regime, was as follows :-

\begin{tabular}{|c|c|c|c|c|c|c|}
\hline \multirow{3}{*}{$\begin{array}{l}\text { Pêrak } \\
\text { Sělangor } \\
\text { Sungei Ujong }\end{array}$} & \multicolumn{2}{|c|}{ Mexican dollar } & 00600 & \multicolumn{2}{|c|}{ sane } & $\varepsilon 45,000$ \\
\hline & 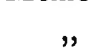 & $"$ & I I 5,65 I & ", & $"$ & 23,000 \\
\hline & " & , & 66,472 & $"$ & $"$ & I 3,000 \\
\hline & & tal & $\$ 408,35^{6}$ & & & 681,000 \\
\hline
\end{tabular}

For the period under review, i 876 to I 888 , the figures of revenue and expenditure are sufficiently interesting to be quoted in extenso:- 
EVOLUTION OF RESIDENTIAL SYSTEM 223

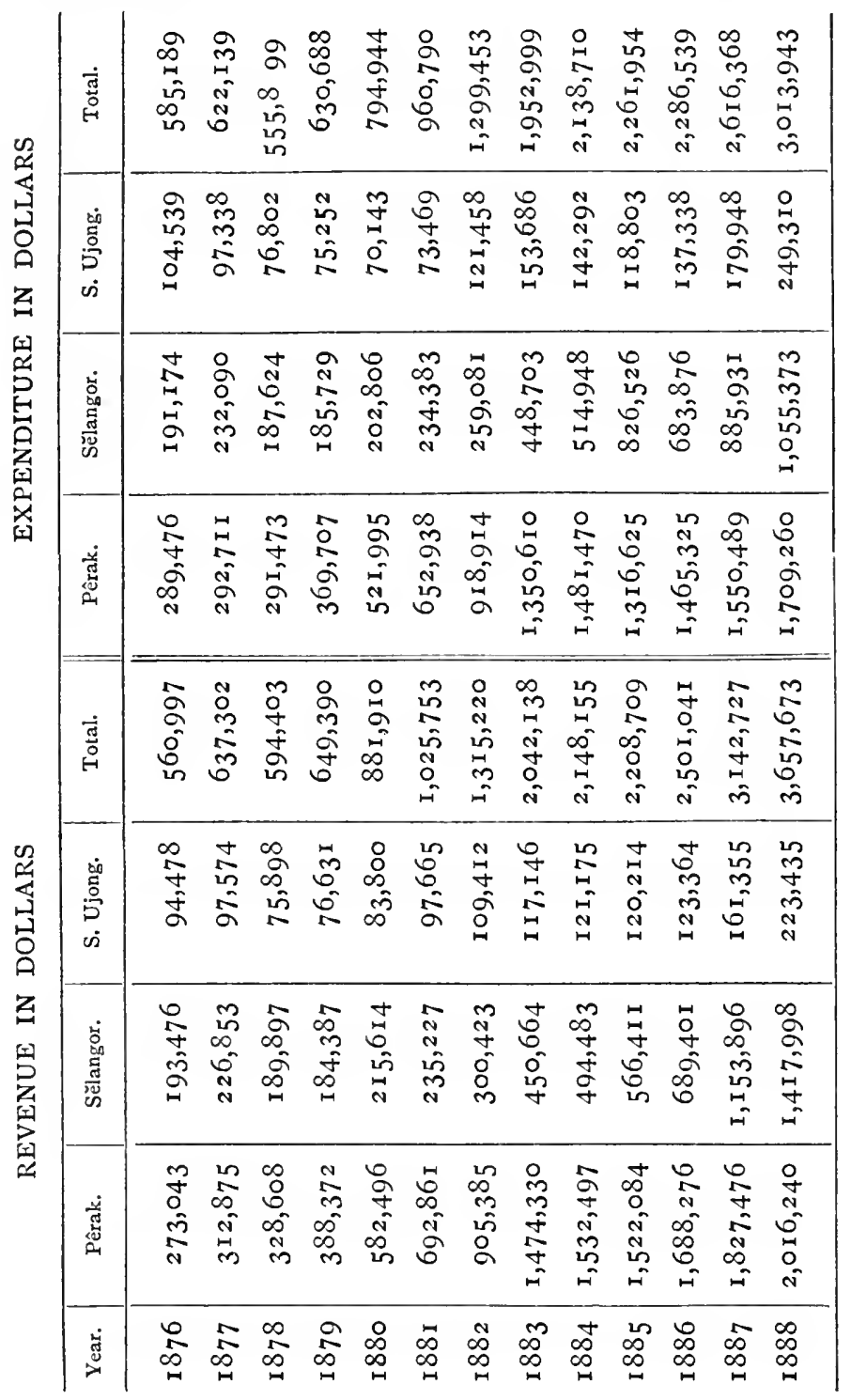


The first trade returns were compiled for the year $\mathbf{1 8 8 2}$, when the imports were valued at $\$ 5,669,078$ and the exports at $\$ 5,538,64 \mathrm{I}$. In $\mathrm{I} 888$ the values had risen to: imports, $\$ 17,327,392$ and exports, $\$ 19,784$, I IO. In 1876 the value of the dollar was $4 \mathrm{~s}$., and it gradually but constantly depreciated, so that in 1882 it was about $35.9 \mathrm{~d}$., and in 1888 about 3 s. In I 879 the population was roughly estimated at, Pêrak 81,000; Sělangor, 40,000; Něgri Sambîlan, 30,000.

One of the special objects of the Resident was, "to initiate a sound system of taxation, with the consequent development of the country, and the supervision of the collection of the revenue so as to ensure the receipt of funds necessary to carry out the principal engagements of the Government and to pay for the cost of the British officers and whatever establishments may be necessary to support them."

After the preservation of peace that was the injunction of greatest importance. It has been already stated that the Mantri of Lârut had incurred heavy liabilities in his attempts to restore order in Lârut. The Viceroy of Sellangor had deeply pledged the credit of that State in his efforts to drive out his adversaries, the formidable band of Rajas who defied his authority. But when the British Government interfered and had to send a considerable military expedition to Pêrak and Sungei Ujong, the available balances of the colony were quickly exhausted, and it was necessary to borrow funds to defray the expenses of the Imperial troops, and to provide the Malay States with means to carry on the administration. All these debts and advances had to be repaid, so the advisers began their work heavily handicapped. Almost the first "advice" the Resident had to give (and insist upon) was that all revenue must be collected by Government officers, in the name of the Government, and be paid into a Government Treasury. That in itself was a very 
unpopular measure, only carried into effect by the "peaceful persuasion" of an armed police force. The result was that every chief in the country was immediately deprived of his income, and the Government had to provide for him by giving him a fixed allowance at least as large as the income he had hitherto enjoyed. The heavy liabilities incurred in the name of the State, the cost of the British military expedition, the Malay Civil List, the general charges of administration, the allowances of one very long list of Malay Rajas and officers, and the pensions of another, made the Resident's early days a perpetual nightmare, a ceaseless struggle to make bricks without straw. As soon as the people realized that the Resident held the State purse, the poor and needy, the indigent Rajas and manumitted slaves, went quite naturally to him for relief, and as they could not understand matters of which they had no practical knowledge, they simply refused to believe that the representative of the British Government was not in possession of an inexhaustible supply of dollars, and their importunity and insistence were so great that the only means of securing a little peace was by dispensing private charity as long as the Resident had anything to give. Inability to do more than give all he had, and still leave many unsatisfied, was one of the reasons which induced Mr. Davidson to resign his post as Resident of Pêrak; the other contributing causes being differences between himself and Singapore on matters of policy. His successor, Mr., afterwards Sir Hugh, Low, G.C.M.G., who came from Labuan in 1877 , and remained as Resident of Pêrak till I 889 , was probably more victimized than any of his colleagues, either before or since, for his private generosity had no bounds.

Sir Hugh Low assumed his duties at a critical moment for though the forces of disorder were broken, the obstructive chiefs dealt with, and both Abdullah and Ismail had been removed, there were still powerful chiefs in covert 
opposition to the Resident if they dared not resort to open resistance. Their influence, however exercised, was sufficient to determine the attitude of large villages like Kota Lâma, already mentioned, and others, the headmen of which had either been punished for the part they had taken in the murder of $\mathrm{Mr}$. Birch and the subsequent fighting, or who were related to those who had paid this penalty. Most of the crime of the country could be traced to these places, and whenever an arrest had to be made the task was one of great delicacy and danger.

Raja Yusuf had been appointed Regent of Pêrak, and partly for his own safety he had settled himself in a village called Sayong, on the opposite bank of the Pêrak River to Kuala Kangsar, where the Resident lived. The Regent knew the country better than any man, and his loyalty to the British Government was never questioned; but his unpopularity continued to the day of his death, when the posthumous title given to him was "the late Sultan God-pardon-him." It will be understood, therefore, that in times of difficulty it was seldom advisable to act on the Regent's suggestions, for his principal aim was to "get at" those who had declined to support his claims to the position of Sultan.

Fortunately a great safety-valve was discovered in the constitution of a State Council, on which the Regent, the principal chiefs, two or three of the leading Chinese, and the Resident and Assistant Resident had seats. The functions of this Council were mainly legislative. They discussed and passed all the legislative enactments required by the State. All death sentences were referred to them, and they decided whether they should be carried out or modified; they dealt with the appointments and salaries of all Malay chiefs and head-men, with Civil and Pension Lists ; the annual estimates of revenue and expenditure were laid before them for their information, and the Resident discussed with the Council all matters of 
importance in which the members were likely to be interested. The institution served its purpose admirably; the Malay members from the first took an intelligent interest in the proceedings, which were always conducted in Malay, and a seat on the Council is much coveted and highly prized. A tactful Resident could always carry the majority with him, and nothing was so useful or effective in cases of difficulty as for those who would have been obstructive to find that their opinions were not shared by others of their own class and nationality. It was perhaps not altogether surprising that the Regent not infrequently found himself in a minority of one.

The Pêrak State Council proved such a success that similar Councils were instituted in each of the States, and the procedure in all is identical.

When Sir Hugh Low went to Pêrak he was a stranger to the Malay States, his previous service having been in Borneo; he was therefore furnished with very full instructions, his attention was directed to every important question then pending, and he was advised as to the lines on which they should be dealt with. Debt slavery was then one of the chief stumbling blocks, and it was not till I January, I 884, that it was finally abolished in Pêrak, though it was quickly got rid of in the other States. Sir Hugh Low had some difficulty with Chinese secret societies, but his principal anxiety was to raise enough revenue to meet the administrative charges and reduce the liabilities with which the State was burdened. In this he was completely successful, for by nursing the revenue and insisting upon strict economy in expenditure, he completely freed the State of all debt in six years. When it is stated that these liabilities amounted to $\$ 800,000$ (about $£ \mathrm{I} 60,000)$ this must be regarded as a very remarkable performance. The Sělangor debt had been bonded, and the bonds were drawn and paid off as funds were available. 
To the people of the country the greatest innovation was the institution of courts of justice (presided over by European magistrates, often assisted by Malay magistrates), where all classes and nationalities, Europeans, Malay Rajas and raiats, Chinese capitalists and coolies, were treated alike. The law administered was the Penal Code of the Straits (an adaptation of the Indian Penal Code), with codes of civil and criminal procedure and other measures drawn on the pattern of Indian and Colonial Acts and Ordinances. For many years the present Sultan of Pêrak sat as judge of the Kuala Kangsar Court (the centre of the largest Malay population), and discharged his duties most satisfactorily. Every State was divided into districts, and in each district there were one or more European magistrates, and usually one or two Malay magistrates with limited jurisdiction. The districts were again sub-divided into Mukim and villages with their own Malay head-men, called Pĕng-hulu, and these most useful officers were armed with commissions setting out their manifold duties, which mainly consisted in keeping the peace, arresting offenders, and sending them to the nearest police station; reporting accidents and the outbreak of infectious disease, collecting land and other revenues, settling small disputes, and dealing with minor offences within their very limited power as magistrates.

All the States depended for their revenue upon the tin mines, and it was of the first importance to provide regulations to govern the mining industry, and to supply the miners with means of transport in the shape of roads or navigable rivers. Many otherwise navigable streams were rendered impassable by great forest trees falling across them, and by the bed of the stream being blocked by the accumulated timber of ages. Such rivers were cleared at considerable expense, and kept free of timber by working parties until other and better means of transport were provided. 
Tin mines in the Malay States are, in the enormous majority of cases, open workings, because the alluvial deposits are rich, and their exploitation is much less expensive, and involves less risk than underground and rock mining. The presence of tin is ascertained by boring, by general appearances and the proximity of existing mines, or by divination and the employment of a Malay Pâzuang, in this case a tin-finder, who, working on almost identical principles to those used by water-finders in England, prospects the surface of the land with a wand, and declares that it contains or does not contain tin. The Chinese, the first real miners in the country, have always employed the Pâwang and followed his advice with great confidence, often with the happiest results; but in old days it was usual, especially in shallow ground, to support the Pâzang's opinion by digging pits; nowadays boring is practically universal. When a block of land has been selected and the authority of the Land Office obtained to work it, a great hole is dug in the ground; the spoil is thrown on one side, on worked-out land, or wherever permitted by the mining inspectors, and the tin-bearing stratum may be on the actual surface or at depths which vary in different localities from one or two to 250 feet. The average depth is about twenty-five feet from the surface. This stratum may be from a few inches to many feet in thickness, and it lies on bed rock consisting of limestone, decomposed granite, schist or slate, or on beds of clay which in some cases are fine kaolin. In old days it used to be supposed that this kaolin rested on bed rock, and that whether that were so or not there was no tin beneath it. That theory is now exploded, and a second and even a third layer of tin ore has often been discovered at some depth below the first layer of kaolin. The tin ore appears mixed with alluvial detritus in various forms, from great boulders to pebbles, and more commonly fine or coarse, black or white or grey grains, mixed with ordinary 
sand. Sometimes also tin ore is found mixed with stiff clay, which has to be "puddled" by hand or machinery. The layer containing this "wash-dirt" is called kârang in Malay, and the value of the mine depends upon the thickness and richness of the kârang and, to some extent, on the depth of the overburden. The Chinese work their mines on a primitive but very effective plan. First, the land is cleared of jungle by Malays or aborigines. Simultaneously the erection of the living houses is commenced. The laying out of the mine and the arrangements for bringing in water for dressing the tin ore and working the water wheel for the Chinese pump next engage the attention of the miner. The Chinese method of bringing in water for the purposes of the mine, is simple and economical. The miner may have to make a dam and lead the water by means of a race for some hundreds of yards. $\mathrm{He}$ is ignorant of the use of a level, and dispensing with the services of an engineer he makes his calculations entirely with his eye with marvellous accuracy. In laying out the mine due care is taken to provide a suitable site for the washing of the ore, and for the continuation of the watercourse at a suitable level as the mine is opened up. The preliminary operations concluded, the work of removing the overburden is commenced. This is either done by labourers on contract, in which case the owner of the mine takes any profit there may be; or by labourers working the land on tribute, in which case the landowner only receives his tribute, and is not liable to the labourers if his mine does not turn out a financial success. Except in mines worked on tribute, the kârang, or wash-dirt, is generally raised by labourers on wages. The reason for this is that the kârang does not lie evenly, the richest pockets often occurring in crab holes or under huge boulders, the removal of which would not pay the labourer working on contract. As the overburden is removed and the workings 
are constantly deepened, the bottom of the mine is reached by step-ladders made by cutting flat steps, at an acute angle, in the trunk of a tree. The Chinese run up and down these ladders with bare feet, carrying baskets of spoil slung at either end of a carrying-stick. The mine is kept comparatively dry by one or more endless Chinese lifting pumps, driven by a stream of water working on a small overshot wheel at the surface of the mine. For many years all large mines have been drained by English steam pumps. When the kârang, or wash-dirt, is reached the surface is cleared of overburden, and the wash-dirt is carried up in baskets and stacked in heaps ready for washing. The washing is done in a coffin-shaped wooden trough, through which a stream of water is run while one or two skilled coolies, standing in the trough, rake the wash-dirt as it is thrown in. The floor of the trough is inclined at a slight angle, and as the wash-dirt is constantly raked, and pushed by the workers' feet to the top end of the trough, the heavy ore remains, while the sand and pebbles are carried away by the water. The clean ore is then ladled out of the trough, placed in buckets, and carried away to be smelted in charcoal furnaces, or done up in bags and sent to the great smelting works of the Straits Trading Company in Singapore and Province Wellesley. Clean ore of the oxide of tin yields about seventy per cent of pure tin.

I have said that the protected Malay States depended mainly on the tin mines for their revenue, and it was the first care of the Government to foster the industry by every legitimate means. As early as I882 a French company began to mine tin in the Kinta district of Pêrak, and has extended its operations to the other States. Since then other Europeans have formed companies for the same purpose; but it was the Chinese who began the work, who have continued it ever since, and whose efforts have succeeded in producing more than half of the 
world's tin supply. Their energy and enterprise have made the Malay States what they are to-day, and it would be impossible to overstate the obligation which the Malay Government and people are under to these hardworking, capable, and law-abiding aliens. They were already the miners and the traders, and in some instances the planters and the fishermen, before the white man had found his way to the Peninsula. In all the early days it was Chinese energy and industry which supplied the funds to begin the construction of roads and other public works, and to pay for all the other costs of administration. Then they were, and still they are, the pioneers of mining. They have driven their way into remote jungles, cleared the forest, run all risks, and often made great gains. They have also paid the penalty imposed by an often deadly climate. But the Chinese were not only miners, they were charcoal-burners in the days when they had to do their own smelting; they were woodcutters, carpenters, and brickmakers; as contractors they constructed nearly all the Government buildings, most of the roads and bridges, railways and waterworks. They brought all the capital into the country when Europeans feared to take the risk; they were the traders and shopkeepers, and it was their steamers which first opened regular communication between the ports of the colony and the ports of the Malay States. They introduced tens of thousands of their countrymen when the one great need was labour to develop the hidden riches of an almost unknown and jungle-covered country, and it is their work, the taxation of the luxuries they consume and of the pleasures they enjoy, which has provided something like nine-tenths of the revenue. When it is possible to look back upon a successful experiment, it is always of interest to ascertain the determining factors, and how far each affected the result. The reader should understand at once what is due to Chinese labour and enterprise in the evolution 


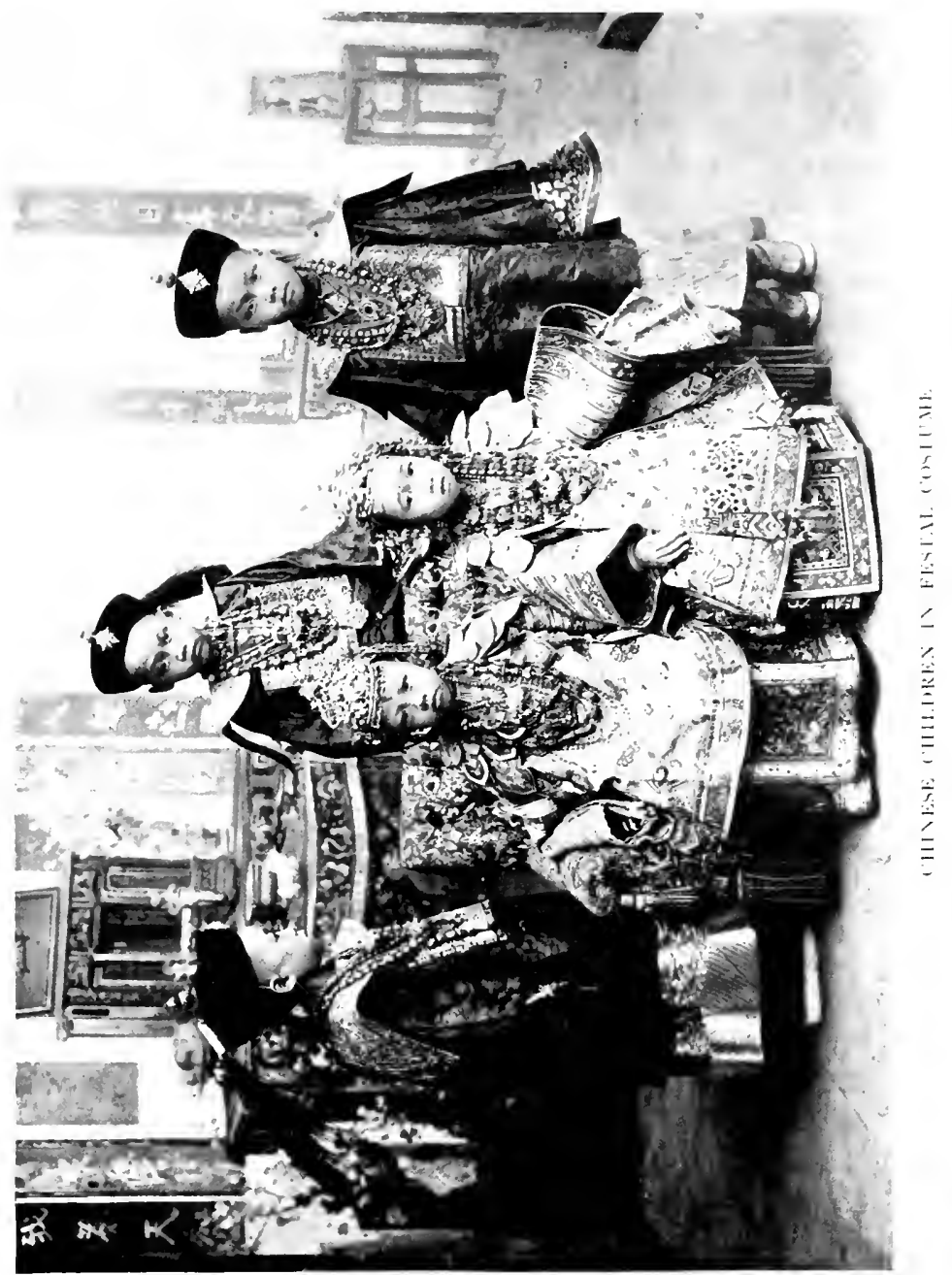



of the Federated Malay States. The part played by the Malay has already been told: it was mainly negative; how far the Government officials, the European planters, and the Indian immigrants contributed to the general development of the country and the position it now occupies will be described in a subsequent chapter.

In the first ten years or so after the appointment of British Residents mining was usually carried on by a few Chinese capitalists working with their own imported and indentured labourers. The contract was for 360 days' work, and the coolie received hardly any wages at all, though his passage from China was paid; he was fed and clothed, occasionally received small sums of money for himself, and about twenty shillings to send to his friends in China. In those days there was a great demand for labour, and the main difficulty was to prevent indentured coolies absconding from the employer who had introduced them, or taking service with some one else, probably in another State. An attempt was made to put a stop to this practice by the issue of discharge tickets and free man's tickets, without which it was understood that an employer would not engage strangers asking for work at the mines. The system worked fairly well, but it had inconveniences, and it was abandoned, partly because indentured labour gradually became less popular as the country developed, and partly because men who had returned to China came back with their friends, and a system of co-operative working grew up and to a large extent took its place. By the co-operative system the owner of a likely piece of mining land looks out for and engages a mine manager, who has full control over the coolies, and works the mine under the occasional inspection and direction of the owner (usually called the "advancer") or his agent. A large shed is then built to house the coolies, and a board is posted on the land stating the terms on which labourers are invited to work. 
Roughly speaking, the terms are that the advancer will find all the capital and will supply the coolies with whatever they require (including small advances of money) at rates above the market price. Every coolie who likes the prospect gets his name written on the board, and is supplied with a small book, in which are entered all the goods and money supplied to him from time to time. The notice on the board also sets out that the tin recovered will be sold, and the accounts made up, at the end of six months' work, when the net profits, after payment of all expenses of every kind, will be divided in certain proportions, so many shares to the advancer (not necessarily the owner of the land, but he who finances the whole undertaking), so many to the mine manager, and so many to each coolie.

In every building where the coolies are quartered there is posted a roll with the names of the labourers in that shed. This roll is entered up daily, and totalled at the end of each Chinese month, so that the coolie can compare it with his own book, and when the accounts are finally made up he can calculate his own share of the profits. The result is that, if the ground is rich in ore, the advancer makes a very good profit, and the manager and coolies also get a respectable share. If the value of tin produced does not quite cover the expenses, the advancer still makes a profit on everything supplied to the coolies, though the enterprise seems to be a failure. In that case the coolies get nothing, but they have been fed and clothed and housed for six months, and received cash advances as well. When the venture is a complete, or nearly complete, failure, the coolies lose the value of their labour as before, but the whole money loss falls on the advancer. When one advancer has been ruined over a mine another will take it up, possibly with the same result, and a third advancer with more means may make a large profit out of the business. In these cases local 
custom governs the very intricate questions which arise; and, if the mine finally pays, the expenditure of the last advancer is first settled, then the debt to the previous advancer, and finally the man who originally opened the mine is paid. The disposal of further profits may be a matter of arrangement amongst the parties, or may all go to the last advancer. The local theory is, that it is the man who eventually makes the mine pay who deserves the most consideration.

Besides the co-operative method, a popular plan amongst small men who have no capital is for a few of them to club together to take out and work a mining licence. The area does not exceed five acres, and the work done is really "fossicking," but it often yields a very good profit, and eventually enables the licence-holders to take out a mining lease (the term is twenty-one years, which can be renewed), and work it in the ordinary way. The mining licence is for twelve months, and is renewable.

The most important and valuable rule laid down in the Malay States in connexion with land of any kind was that every stream and water-course in the country should remain under the absolute control of the Government, and no acquisition of any quantity of land, for any purpose, should give the lessee any rights whatever in regard to water. The most valuable mines are in large valleys drained by one or two streams, and it is therefore of the utmost importance for the workers at the tail of a valley that those with land at the head of it should not be able to shut off the water, or take more than their fair share. Government inspectors of mines see that the water is fairly apportioned and prevent disputes which, in times of drought, would inevitably lead to daily fights. It is impossible to over-estimate the value of this apparently simple but probably unique regulation. It gives the Government complete authority over the working of all 
mines, makes anything like a monopoly of water supply impossible, and secures to all a fair share of that force which is indispensable to successful mining. Miners from California, Australia, and other parts of the world have expressed their great satisfaction with this regulation, which was introduced by the British Residents in the beginning of their regime.

At first the duty on tin was high, and, as the price of the metal is subject to great fluctuations, the duty pressed hardly on miners when the price was low. To meet the difficulty it was often necessary to vary the duty, but after the introduction of Federation the duty was adjusted to a sliding scale in proportion to the market value of the metal.

For some years the land laws were of the simplest possible kind, and, until the construction of roads, the land had no market value outside the towns. Indeed, the Malays, especially in Pêrak, strongly objected to the payment of any land rent on that ground, and it took some time to convince them that they would be great gainers by being put in possession of an indefeasible, easily saleable and transferable title, in return for an almost nominal quit rent. The construction of roads, the growth of towns and villages, and the general increase of business and prosperity brought this home to them, and landowners of all classes are now almost as ready to quarrel about their boundaries as they are in other countries. Until the administration was properly organized, with complete staffs of land and survey officers, it was impossible to undertake a regular land settlement. That has all been done since, but the object at first was to see that every man's claim was properly demarcated and roughly surveyed, that the owner was furnished with a permit to occupy, an agreement for lease, or a lease, and that he paid the annual quit rent. The leases issued are for 999 years or in perpetuity. 
About five years after the appointment of British Residents, several experienced Ceylon planters visited the Malay States, and applied for about 100,000 acres of land, in Pêrak, for agricultural purposes. The Resident was very anxious to grant it on terms which would satisfy the applicants, but an order was sent from Singapore refusing a longer lease than ninety-nine years. All the applications were withdrawn, and, when a more liberal and enlightened policy was adopted, it took a long time and much trouble to induce reliable men to invest their money in a country so little known and so undeveloped as the Malay Peninsula. Thus the mistake of the Indian Government in the Straits was repeated, but fortunately was not allowed to retard the advancement of the country for more than a few years.

All the money which the Residents could borrow from the Colony, and all the surplus revenue at their disposal after meeting the absolutely necessary charges of administration, was expended in the construction of roads. The mines, on which, as has been explained, the Government depended almost entirely for revenue, were situated inland, around the foot hills of the main range of mountains. They were distant from the sea from ten to about thirty. five miles as the crow flies, and the earliest attempt to open the country was the construction of cart roads from the mining centres-Taipeng, in Lârut; Kuala Lumpor, in Sellangor; Seramban, in Sungei Ujong-to the nearest water navigable by small steamers. That done, it was necessary to begin a network of roads from the mining centres to all the nearest and richest known mining fields. It is not an easy task to construct really good wellgraded roads through an unexplored country, covered with virgin forest and the dense undergrowth of a moist tropical climate, with hill and swamp alternating, and a rainfall of from so to 160 inches annually. Those who see the splendid roads which now traverse the Protected 
Malay States in every direction will not understand the difficulties experienced in these early days, but they can get a good idea of them if they like to make their way into a State outside the Federation and try to travel through it. The funds for road-making and other public works were, for the first few years, very small, and it was only by the most rigid economy that any construction at all could be done, for it was understood that, however the estimates were framed, the expenditure must always be kept within the actual receipts. In I 882-3 a system of road-making was introduced into Sĕlangor to meet these conditions. Six-foot bridle roads were constructed, with a good gradient, no metalling, and very simple and cheap bridges. This was done at about $£ 150$ a mile, and as soon as the traffic justified the expense, the $b$. idle road was made wide enough for cart traffic, and eventually the earth road was converted into a first-class metalled road with permanent bridges. A road of that class, if made of that type in the first instance, cost from $£ 1000$ to $£$ I 200 a mile.

This system of road-making was soon adopted in the other States, and it had these advantages: the rapid provision, at a small cost, of means of transport by a welltraced road which could be kept in order at very small expense; the opening of the country and the opportunity -quickly seized-of putting up small native houses in the middle of a few acres of good land, on the side of a track which was almost certain to become a great highway. Malays, Chinese, and Indians, but specially Malays, were thus induced to take a large interest in the earlier stages of development. A bridle road was no sooner completed than small houses, plantations, and fruit and vegetable gardens sprang up along its whole length. When funds were available and the traffic showed that the road was proving its use, it was widened and metalled, villages sprang up beside it, and all the land served by the road 


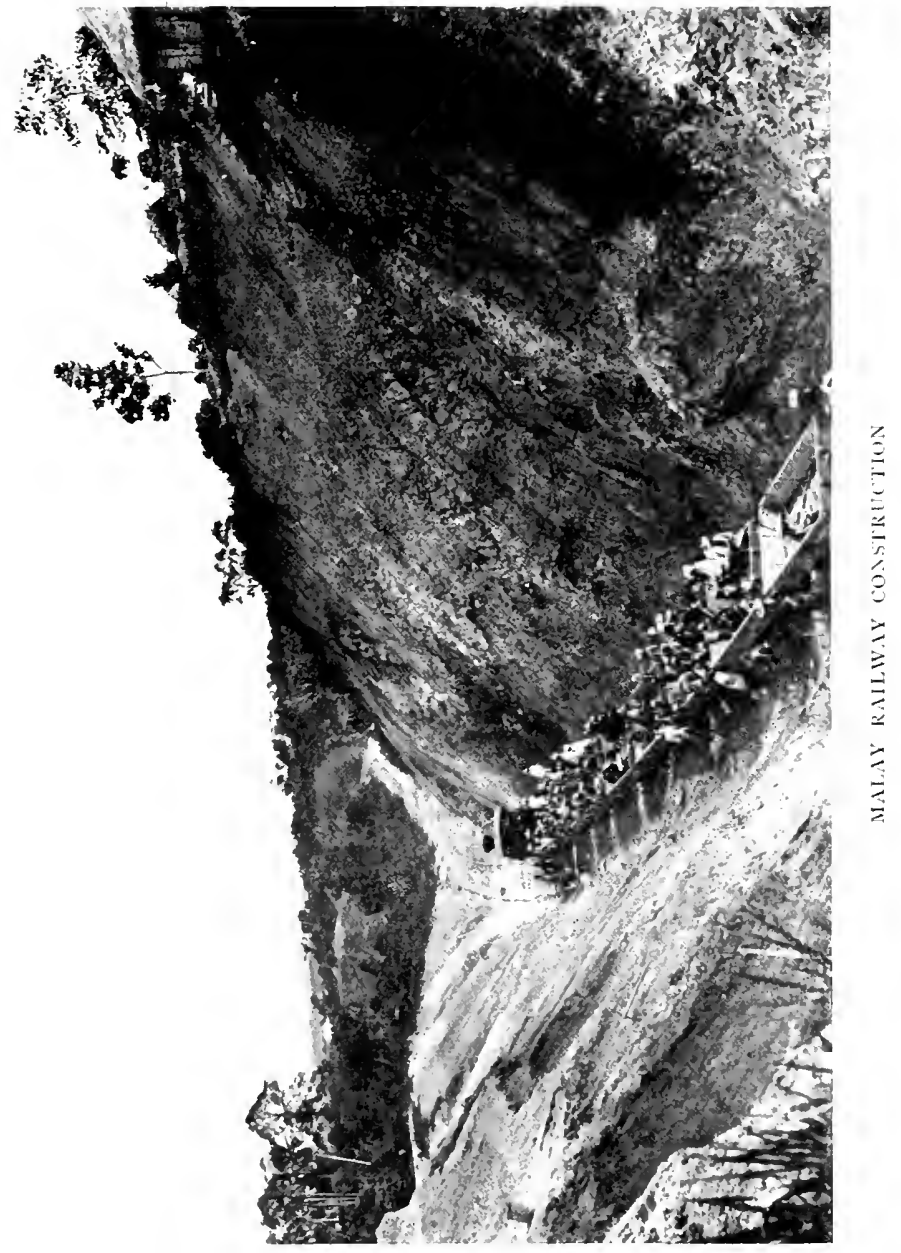



appreciated in value. There were no rich men in the States, so, to encourage the development of mines and settlement on the land, the Government made advances to enterprising Chinese miners and immigrant agriculturists of all classes. All advances made to Chinese were faithfully repaid.

Efforts were made to encourage the building of villages all over the country, and round the head-quarters of every district settlers congregated, small towns were laid out, shops and markets were built, and everything was done to induce the people to believe in the permanence of the new institutions. The visitor who now travels by train through a succession of populous towns, who lands at or leaves busy ports on the coast, can hardly realize the infinite trouble taken, in the first fifteen years, to coax Malays and Chinese and Indians to settle in the country, to build a better class of house than the flimsy shanties or adobe structure hitherto regarded as the height of all reasonable ambition.

As the villages grew and the roads joined up the various mining fields and scattered hamlets, village councils, styled Sanitary Boards, were instituted to regulate the markets, sanitation, slaughter-houses, laundries, water supply, and the hundred and one improvements of rapidly growing centres of population. Every nationality is represented on these boards, and the members take an intelligent interest in municipal administration.

Post offices were opened as soon as there was a building in which to transact the business, and the construction of telegraphs was carried on pari passu with the making of roads, sometimes even ahead of them.

The first railway undertaken was a line of only eight miles from Taipeng, the mining centre of Lârut, to a point called Sa-pĕtang (afterwards named Port Weld), on a deep water inlet of the Lârut River navigable for small steamers. That line was constructed by two divisions of Ceylon 
pioneers, lent by the Government of Ceylon, and before it was completed (in 1884) Sělangor had embarked upon a much more ambitious scheme-the construction of a railway from its mining centre, Kuala Lumpor, to the town of Klang, a distance of twenty-two miles, through difficult country, with a considerable bridge over the Klang River. But the railway was a necessity if the State was to be properly developed, and application was made to the colony to advance the funds required. The application was granted and the work was at once begun; but long before it could be completed the colony, being in want of money, applied for immediate repayment, and it was fortunate that the rapid progress of the State made it possible to satisfy this demand and still complete the line out of current revenues. As soon as the railway was opened for traffic the receipts so far exceeded the working expenses that the line earned a profit equal to 25 per cent on the capital expended. It may be questioned whether that record has ever been equalled in railway history. Both the Sĕlangor and the Pêrak railways are metre gauge, and that system has been maintained in all subsequent railway construction in the Malay States; but the weight of the rails, originally $46 \frac{1}{4} \mathrm{lb}$. to the yard, has been increased to $60 \mathrm{lb}$., and the extensions now in hand (the Johore State Railway, financed and constructed by the Federated Malay States) are to have $80-1 b$. rails. In this earliest railway work a very high standard of excellence was adopted; no gradient was steeper than I in 300 , and no curve more severe than 15 chains radius. In subsequent work it was found advisable to relax these conditions; but the financial success of the Sĕlangor line was, to a large extent, due to their observance.

The railway undertaking was not allowed to interfere with the construction of roads, and by 1885 Sělangor had driven a cart road through the jungle from its boundary with Pêrak in the north to the borders of Sungei Ujong in 


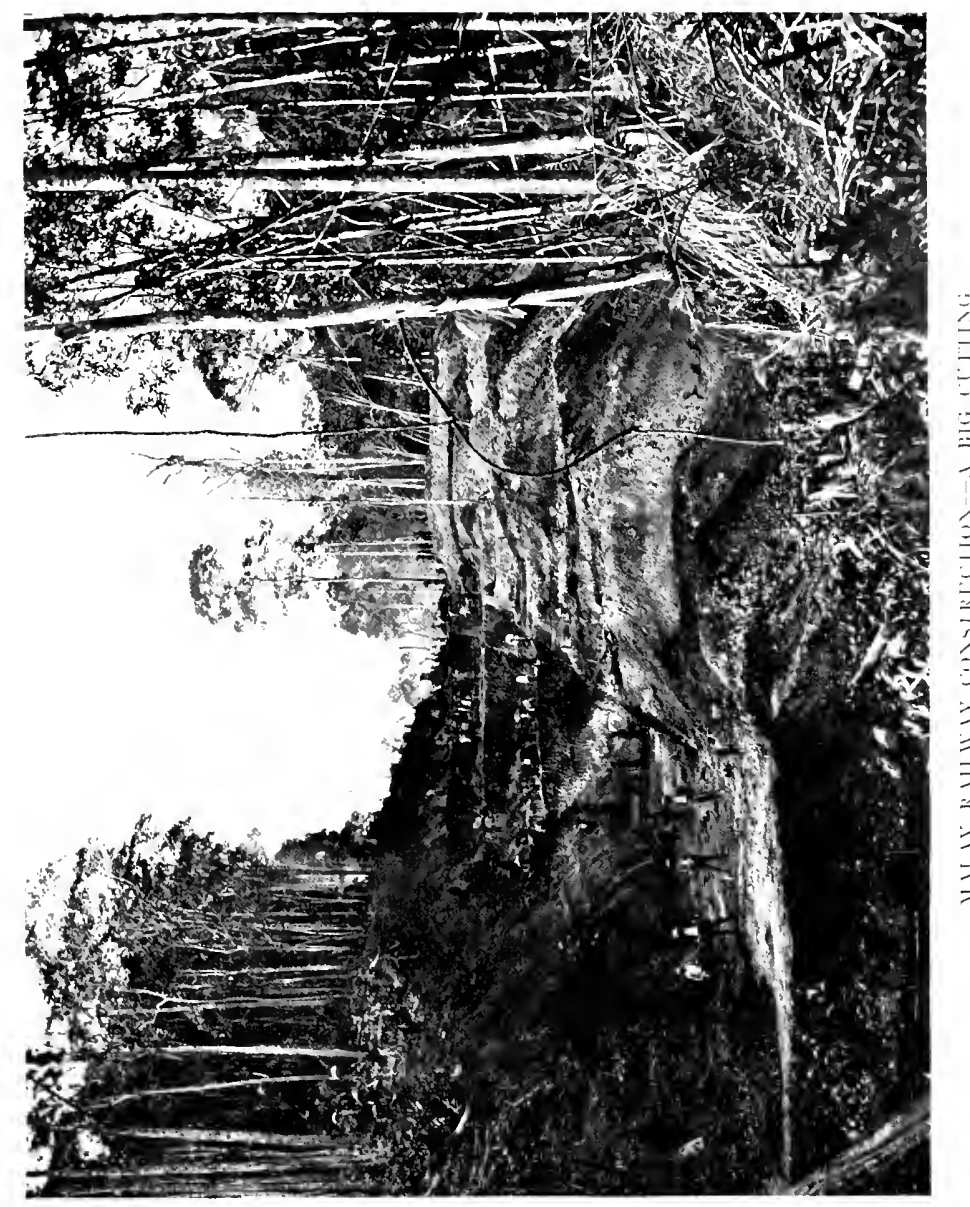



the south. Sellangor was thus the first State to complete its section of the main road which runs in an unbroken line from Province Wellesley to the boundaries of the Nĕgri Sambîlan and Malacca; but a main trunk railway now traverses the same country, and the Federated Malay States have already, at their own expense, carried it for another twenty-five miles through Province Wellesley to a terminus on the Prai River, opposite Pinang, they are completing the southern extension, 120 miles through Johore territory, to the capital of Johore on the Johore Straits, and they have built and just purchased from the Colony the Malacca railway, from their own main line to the town of Malacca.

In such a country as the Malay Peninsula, with the climate of a perpetual Turkish bath, and a mining population of aliens working in newly cleared and newly turned ground, it was certain that there must be a great deal of sickness and a high death rate. Amongst the first Government buildings constructed were hospitals, and one of the heaviest charges on the revenues was the upkeep of these establishments. The Federated Malay States contain prisons built on the most approved designs and managed on a system which leaves little to be desired, but it is doubtful whether any other Eastern administration has done so much for its sick. The calls on the resources of Government were so heavy that Sir Hugh Low levied a capitation fee of one dollar per head on all Chinese, as a contribution to the expenses of building and maintaining the State hospitals. All food, medicine, and attendance was, and is, given free, but the Chinese strongly objected to this tax: it never was levied in the other States, and was abolished in Pêrak in I884. Every district in each of the States has its hospital, often more than one, and in populous districts the institution consists of many wards and other buildings arranged in carefully laid out grounds, planted with palms, 
beautiful trees, and flowering shrubs, very restful to the eye. The numbers of patients treated in the course of a year run to many thousands (in 1884 over thirteen thousand cases were treated in Pêrak alone), and the sums expended by the Government on the medical department, with all its surgeons and assistants, nurses, dispensers, dressers, attendants, cooks, gardeners, gate-keepers, etc., amount to a very large total. Though Malays, as a rule, decline to enter the hospitals as in-patients, the Chinese and Indians have no hesitation in doing so, and the Government has every right to be proud of the work it has done in the care of sick people of all nationalities.

For the first twenty years of the residential regime, when that system which may now be taken as established was being worked out by personal endeavour under the eye, the hand, and the authority of the Resident, with only common sense and his own intelligence to guide him, his main supports were the officers in charge of districts, originally styled District Magistrates. Just as when the Resident was alone he had to do everything himself, so they, being alone, were, in their districts, the Magistrate, the Chief of Police, the Public Works and Survey and Land Officer, the Surgeon, the Treasurer, the Coroner, the Superintendent of the Prison, if there was one, the Inspector of Mines in a mining district, or the Harbour Master in a coast district. The magistrate had to travel all over his district, to learn its capabilities, encourage people to take up land and build houses, know every one and be pleasant to good citizens, with at least one eye on the naughtily inclined. $\mathrm{He}$ was liable to be called upon at any moment of the day or night to go anywhere and do anything. The curious thing is that the men who held these posts, though they had passed no competitive examination and had no special training for the work, somehow managed to do what was required of them, and in most cases did it exceedingly well. The 


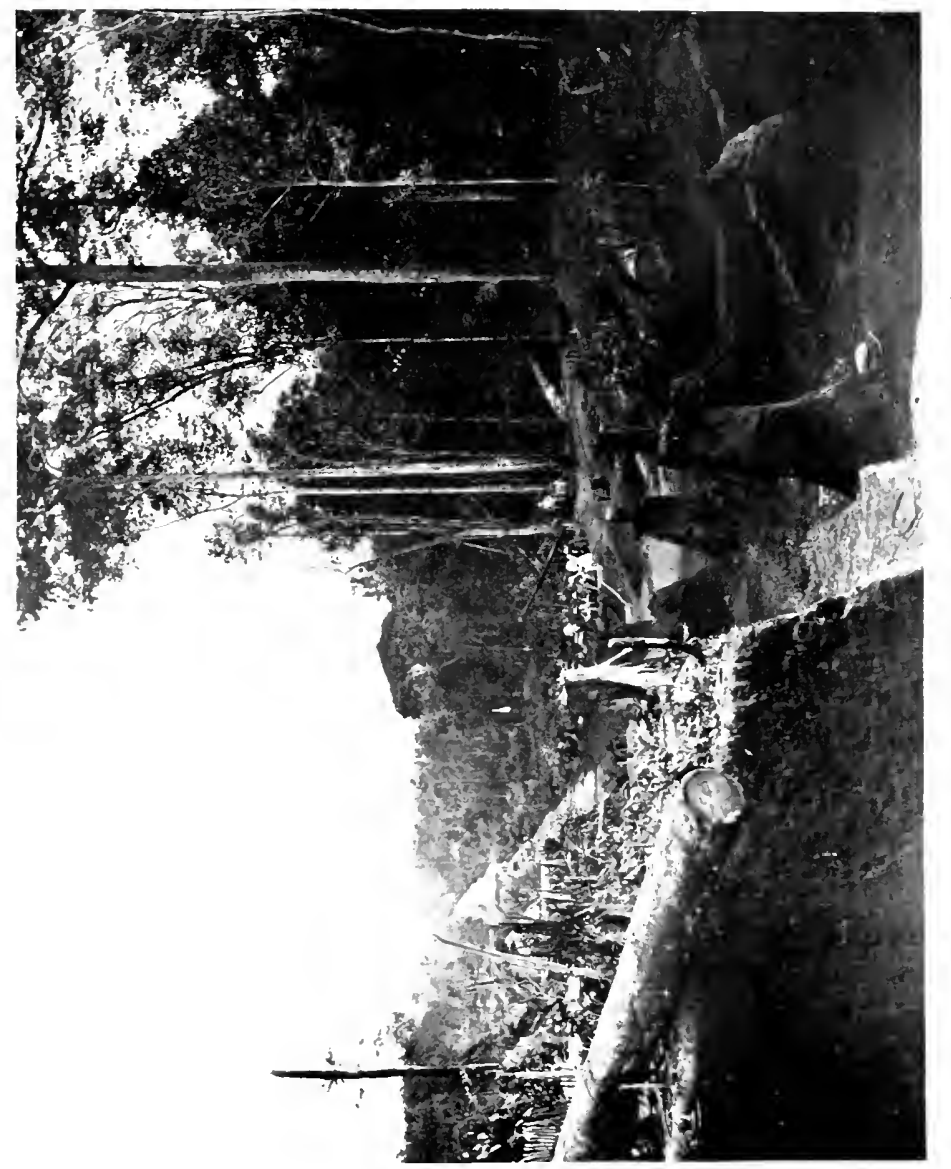

3
3
3
3
3
3
3
3
$=$
$=$
$=$
$=$ 

Malay States were certainly very fortunate in their earliest servants, and it is extremely probable that the work would not have been done so successfully by others with greater intellectual gifts or higher training; just as it is certain that the men who did so well then would not succeed now that everything has been systematized, and the work of every department and every office is of a different and far higher quality. In the Malay States the old order has changed, but the merits and the work of the old order should be recognized at their real value.

A hundred instances might easily be given to illustrate the statement that in early days a man might be called upon at any moment to perform any kind of service; one, however, will suffice. Governor Sir William Jervois was in Pêrak with a dozen Europeans in attendance, and a large number of boats and men had been got ready at Kuala Kangsar to take the party down the River Pêrak, a journey of several days. The start had been arranged for daylight the next morning, but about midnight the Resident, Mr. J. W. Birch, woke me up and told me that one of the boatmen had died of cholera, and, as he came from a place down stream, his people wanted to take the body home for burial. This, the Resident explained, was impossible, for it might result in an epidemic of cholera, and as it was very advisable that no alarm should be caused, the fact of the man's death must be kept a profound secret. For the general safety, the Resident proposed to bury the body at once, and he invited me to join him in seeing that done. I went with him, and we did see it done; very much against the wishes of the Malays, who strongly objected to the whole proceeding. Then I went back to bed, and at daylight we started down river, with a great concourse of boats and rafts, a very brave show. No one knew anything about either the death or the midnight burial; but a few days afterwards I discovered that his friends had dug up the dead man, either just before or 
just after we started, had put him in a boat, joined the rest of the fleet, and, after journeying with us for two days, had landed the body at the man's own village, where his relatives reburied him with due ceremony. There were no other cases of cholera, either amongst our party or in the village where the man found his last resting-place. On another occasion, when the provocation was far less, five hundred deaths resulted from one imported case of cholera. 


\section{CHAPTER XI}

THE CONTINUED EVOLUTION OF THE RESI-

DENTIAL SYSTEM - REVENUE FARMS EDUCATION-LAND SETTLEMENT-IRRIGATION - RUBBER CULTIVATION - CURRENCY_PĂHANG

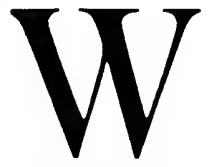

HEN Sir William Jervois left Singapore, early in 1877 , he was succeeded by a civilian, Sir W. C. F. Robinson, who never visited the Malay States during the eighteen months he remained in Singapore. After a short interregnum, during which Colonel Sir A. E. H. Anson, Lieutenant-Governor of Pinang, administered the government, Mr., afterwards Sir Frederick, Weld, G.C.M.G., came from Tasmania, and remained in the Straits till he retired, in the autumn of I887, when he was succeeded Sir Cecil C. Smith, whose term of office expired in 1893.

During these twenty years-to be exact from 1874 till I895-the British Residents gradually built up the system of administration which seemed best suited to the peculiar circumstances, without much more than routine references to the Governor. It was well for the Native States that the men entrusted with this wide authority proved themselves fitted to wield it, and it was proof of the foresight and wise judgment of the Governors that they interfered very little with their officers. The Residents themselves were nominated by the Governor and approved by the Secretary of State. They were chosen as the best and most experienced men for this very special service. A knowledge of the Malay language and character were almost indispensable; though, as has been explained, the 
real character of the Malay was in 1874 practically an unknown quantity. But the disturbances had taught a great deal, and a man who spoke Malay well, who sympathized with the people, and possessed the other necessary qualities already described, felt his way carefully, and, living day and night in a Malay atmosphere, had only himself to blame if he failed to get at the heart of the people and win their respect and confidence.

As funds became available and the administrative machine was built up bit by bit, the Resident collected about him a number of men, Europeans, Eurasians, Malays, Chinese, and Indians to help him in his task. In the first instance, the Resident was quite alone; then he had a clerk or two; a native or a European non-commissioned officer at the head of his police; a Eurasian apothecary in charge of his first hospital; a Malay warder to look after the flimsy building dignified by the name of prison. But things moved quickly, the country was very rich, and only required peace and order to develop with amazing rapidity. Therefore the work contemplated for twelve months was often done in six, villages grew like mushrooms, and the revenue increased so fast that funds were available by the middle of a financial year for services which were considered out of reach at the beginning. Under such circumstances to have tied the hands of the man on the spot, the only man who knew, would have been to retard the progress of the country, simply in order to propitiate the fetish of red tape and follow dictates laid down for totally different circumstances. As the States progressed and the establishments, of necessity, grew to keep pace with the ever-advancing prosperity of the country, the Resident's experience of tropical colony government in all its departments, his foresight, common sense, courage, and adaptability were called into requisition almost hourly. For several years it was understood that only the Residents were servants of the British 
Government; all subordinates were servants of the State which employed them. That rule narrowed the field of selection, but no man who could enter a recognized service through the gate of competition was anxious to seek exile, "to scorn delights and live laborious days" in the wilds of a Malay jungle. Still, for posts of trust and responsibility it was necessary to have Englishmen, ${ }^{1}$ while the clerical service was mainly recruited from Eurasians of the Straits or Ceylon, the rank and file of the police from India and Malay countries, and the railways, post, and telegraph offices from India and Ceylon. Subordinate posts requiring intelligence and financial skill in the holders were best filled by Chinese. Appointments to and promotions in the more important of these subordinate offices were subject to the approval of the Governor; the Resident could only deal with appointments carrying very small salaries.

From 1876 to 1882 the Governor had, in Singapore, a Secretary for Malay Affairs, who not only knew the country and the people, but periodically visited all the protected States, travelled about in them, audited the accounts of the various stations, made suggestions to the Residents on all subjects, and did something to secure uniformity of method when dealing with similar matters in different States. Before and after those dates, until the year 1896, there was no one in Singapore who had knowledge enough to criticize successfully the action of the Residents. Of the States, their topography, chiefs, people, industries, needs, and resources, the Secretariat in Singapore only knew what the Residents chose to tell, and they had not much time for correspondence, or any but rare opportunities of despatching letters to Singapore, or even to a neighbouring State. If there had been any

1 A name which in this book includes Scotchmen, Irishmen, Welshmen, Channel Islanders, Australians, New Zealanders, Canadians, and other white British subjects. 
one in the Singapore Secretariat who, at any time during those twenty years, had possessed a fair personal knowledge of the Malay States, in five years, or far less, it would have been useless, indeed worse than useless, it would have been very misleading; for the States advanced so rapidly along the path of progress and development that in twelve months a considerable mining town would spring up in the midst of what had been virgin forest, and the Resident would write of roads and places never before heard of, and not to be found on any map. Of course there were no maps; they also were the product of the Malay administration, and as articles of comparative luxury, they only came much later, when the value of land, the extension of mines and agriculture, the general development of the country, and the construction of roads and railways, made accurate surveys and plans a necessity. Therefore knowledge of Malay affairs, to be valuable, had to be kept up to date, and that could only be done by constant visits to the country.

The impossibility of a Governor in Singapore exercising any really effective control over men so circumstanced as the British Residents, and with such a difficult task to occupy their whole time, had been so quickly and fully recognized that they were instructed to keep journals of their daily proceedings, and to send these records to Singapore from time to time, as opportunity permitted. Beyond that the Residents sent every year, in October or November, a detailed estimate of revenue expected to be raised from all sources during the ensuing financial year, and of all expenditure proposed to be defrayed for every government service during the same period. This annual Budget had to receive the approval of the Governor before it could be acted upon, and no vote could be altered or exceeded without special reference and sanction. That of course was a very great and necessary safeguard, and it was supplemented by an annual report, furnished about 
April or May, giving the actual result of the past year's working, with all financial and other particulars, together with a general review of the year's transactions, an account of the doings of every department of government and the Resident's own remarks on the general progress of the State. Besides furnishing this Annual Budget and Annual Report, the correspondence of the Resident with Singapore was mainly occupied with the appointments, promotions, salaries, and complaints of Government officers.

After about ten years, the Residents found they no longer had time to keep journals of their daily doings, and that method of supplying information to the Governor was abandoned. The annual Budget and the annual Reports are furnished to the present time, and the latter have always been forwarded by the Governor to the Secretary of State for the Colonies, who causes them to be printed and presented to both Houses of Parliament.

Up till I 896, a Governor who was interested in the Malay States (and it must always be remembered that his first charge was the Straits Settlements Colony) and wished to exercise some influence there, could only do so by visiting the States, getting some idea of their geography, their then condition and requirements, and by making the personal acquaintance of the rulers, the more important chiefs, and the leading Chinese miners and capitalists. That done, it has been easy in modern times (since roads and railways were constructed and the Residents provided with steam yachts) to make opportunities for seeing the Residents and discussing with them and the Malay Rulers any projects of unusual importance. Sir Frederick Weld took an immense interest in the Malay States, and spent a good deal of time travelling about in them, seeing the country and making the acquaintance of the Rulers and chiefs. What he saw convinced him that the Residents could be trusted with the large authority they had 
gradually acquired, and while supporting every project for the development of the States, he stood for the strict observance of our obligations towards the Malays and the improvement of their well-being. Sir Cecil Smith, with a much wider experience of Chinese, Malays, and all the circumstances of this special problem, was not less anxious to help the Malay administrations along the path of progress on which their feet were now so firmly placed. If Sir Cecil Smith's connexion with the Straits will always be remembered by his firm suppression of the Chinese secret societies (a policy in which at the time he received so little support, though his action has been so fully justified by results), his sympathy with the Malay States was evidenced by his strong support of railway development and his keen interest in the advancement of education.

It is not easy to convey a correct idea of the difficulties of correspondence between any Malay State and Singapore, between one State and another, and between the more remote districts of a State and the head-quarters of the Resident. Those difficulties continued until quite recently (1903), when the main trunk line of railway traversing all the western States, with a terminus in Province Wellesley, opposite Pinang, was completed. Until railway communication was established, though the actual distances were comparatively insignificant, the carriage of letters depended upon, first, runners over jungle tracks, then pony carts, and finally railways, in the case of those places which enjoy a train service. That was so far as land carriage was concerned, and when a seaport was reached the mails were carried by small steamers, some of which were subsidized for the purpose, while others were not, but all of them called at sundry coast ports on their way to or from Singapore. Therefore correspondence was irregular, and often subject to very trying delays. Communication between the States was even more uncertain 
until they obtained a through railway service. These circumstances partly explain the fact that each Resident followed his own line in his own State, without any particular reference to his neighbours. Very often he had no experience of any State but the one he was in. $\mathrm{He}$ seldom knew or concerned himself with the affairs of his neighbours, and he probably thought that he was as capable of dealing with any question of administration as another Resident, who might be older or younger than himself, or who had had a longer or shorter experience of Malays and Malay affairs. As already stated, there had been, for the six years from 1876 to 1882 , a more or less effective control from Singapore with an attempt to secure uniformity. But when that ceased with the abolition of the post of Secretary for Native Affairs (and the control had never been absolutely effective) each Resident went his own way and was inclined to resent either suggestion or interference. Some important matters, such as the system of revenue farms, the amount of tin duty, and the rate of quit rent on Government lands, had been established, as regards principle, in the earliest days, and only details were open to varying treatment. Where there was an opportunity for trying experiments it was usually taken advantage of, for the reasons and owing to the circumstances already described. The result was often useful, for amongst a variety of experiments it was possible to realize which had proved most successful. But as time went on and the States grew in importance, these differences, at first irritating, became unbearable and led to federation. The weak point of the system, as then developed, was that it placed too much power in the hands of one man. It may be said that whether that is a bad or good arrangement depends upon the man; but as it is unlikely that there will always be a succession of good men, a satisfactory system must be so conceived that a bad man cannot do an infinity of harm without hindrance. The 
reader must therefore bear the facts in mind, the peculiar circumstances under which the Residents were appointed, the burden of their stewardship and the necessary assumption of large authority if they were to render a good account of it, their isolation and the absence of effective control, the gradual increase of responsibility with the rapid development of the States, the difficulties of correspondence and the want of uniformity in the treatment of administrative details, so that, when the time comes to deal with federation, he will understand why a system which on the whole worked so admirably for twenty years had to give place to the natural outcome of that system.

The year 1889 was notable in the history of the protected States, for in that year Sir Hugh Low retired from his post as Resident of Pêrak. Then Pahang, which had come into the fold late in I 888 , for the first time appeared as a protected State, and the first bank, a branch of the Chartered Bank of India, Australia, and China, was opened at the head-quarters of the Pêrak Government. I have already mentioned Sir Hugh Low's appointment in 1877 and his successful management of Pêrak affairs at a critical tme. It would be difficult to overstate the value of his twelve years' work. He arrived when Pêrak was overwhelmed by a heavy debt, with no visible resources to meet it. He left the State with a flourishing revenue (over two millions of dollars) and a credit balance of $\$ 1,500,000$. If those figures, the peace and order of the State, and the many useful public works completed during the period of his office were the outward signs of his successful administration, the real value of Sir Hugh Low's work was to be found in the influence he exerted to prove to the Malays the meaning of justice, fair dealing, and consideration for their claims, their customs, and their prejudices. That influence was not less firmly and wisely used to teach his officers a lesson of strict integrity, and to insist upon their 


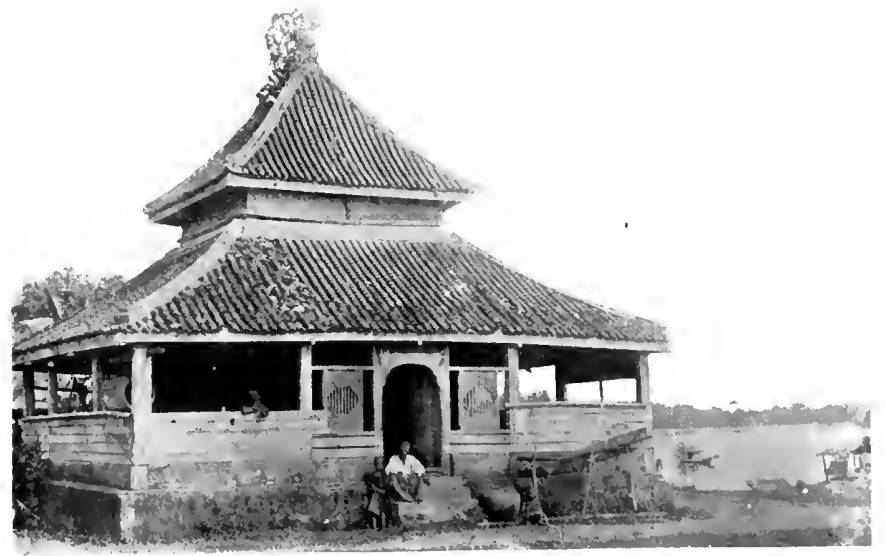

OLI) MOSOUE IX l'ĂHAXg;

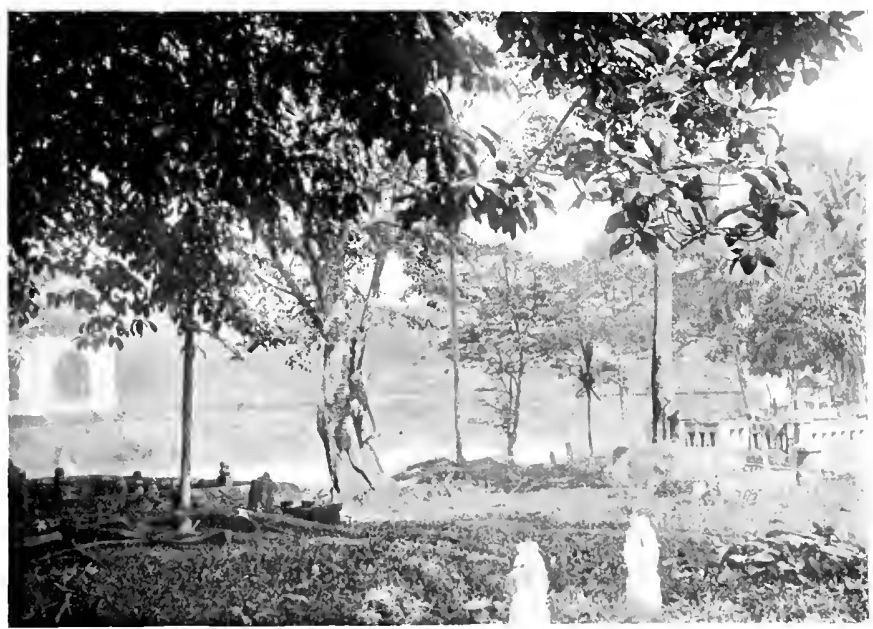

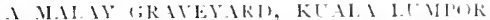



treating all natives with the same courtesy and consideration which he showed himself. Sir Hugh Low understood what others in authority should never forget, that the only way to deal with a Malay people is through their recognized chiefs and head-men. To gain their co-operation it is necessary to show them at least as much consideration as if they were Europeans, and infinitely more patience. Moreover, they should be consulted before taking action, not after. When Sir Hugh Low retired, the Imperial Government recognized his services by bestowing upon him the Grand Cross of St. Michael and St. George; but the people of Pêrak, of all classes and nationalities, having already given him their esteem and affection, kept his memory green, and when he died last year they would mourn him as a friend who " had gone home to the mercy of God."

Reference has been made to the practice of "farming" certain sources of revenue, the principal amongst them being the right to prepare and sell opium for smoking, to manufacture and sell a Chinese spirit called ârak or samshu and collect the duty on all imported spirits, to keep pawnshops and receive articles in pledge, and to open and manage halls where public gambling on certain games was carried on during certain prescribed hours. The regulations governing the right to open pawnshops and deal with pledges, and to tax, manufacture, and sell spirits, are practically the same as those in force in the neighbouring British colony. As regards opium, the Malay States adopted a method different to and perhaps less objectionable than the one recognized in the Straits Settlements. In the Straits the farmer alone has the right to deal with raw opium and convert it into the preparation called chandu, which is used for smoking. With the consent of the Government, he issues licences for the retail of chandu, and the interference of the Government is practically confined to seeing that the chandu is up to a certain standard 
of purity, and that it is not sold at a higher price than that fixed by the Government contract. A chest of fine Indian opium contains forty balls of the raw product. While the price is constantly fluctuating, from under $\$ 750$ to over $\$ 1200$ a chest, the forty balls of raw opium, when "cooked" and made into chandu, will sell for $\$ 2500$ to $\$ 3000$, according to the limit of the Government price. It will be understood that when opium is cheap the farmer is likely to make very large profits, which will be adversely affected by a rise in price. On the other hand, the farmer has to provide the whole preventive service to protect himself against smuggling, and, though his profits are usually very large, his risks are greater than most speculators would care to run. This system is objectionable principally because of the enormous power it places in the hands of the farmer for a period of three years, during which he holds the monopoly. In order to give him a profit and a fair equivalent for the risks the consumer has to pay rather a high price for his chandu. While, therefore, from one point of view, the consumer suffers in order that first the Government and then the farmer may gain, from another point of view the moralist may urge that the more expensive the drug the better for the community.

The Residents in the Malay States understood this system and did not altogether favour it. The miners, the back-bone of the revenue, declared that, if introduced, it would put a stop to their enterprise and ruin the country. They objected to the power which might be wielded by a monopolist who was also a miner, and they declared that unless the coolies could buy cheap opium, they would riot first and then leave the country. The truth or otherwise of these arguments was not put to the test, for the Residents adopted the following system.

The country - for the purposes of these revenue farms -was divided into a coast farm (where there were no mines, and in to which it was exceedingly easy to smuggle 
such a portable and valuable drug as opium), and a restof-the-country farm, which of course included the mines and all the up-country. The coast farm was let and worked on the same system as that pursued in the Straits Colony, only that the maximum price of chandu was a good deal lower than that charged in any of the colony's settlements. The coast districts were, and still are, of much less importance and contained much fewer inhabitants (principally Chinese woodcutters and fishermen) than the mines. Except for use in the coast districts, any one could import raw opium on paying the Government duty, which was at first about $\$ 7$ a ball, and is now $\$ I 4$ a ball. The Government licensed all retail shops, while mine owners and other large employers of Chinese labour imported their own opium, converted it into chandu, and dispensed it to their own employés. After a good many years the Government, in some States, farmed the collection of the opium duty, and while that policy made not the slightest difference to consumers, it enabled the Government to calculate with certainty on the receipts from this source for each successive period of three years. The risks of opium smuggling are small compared with those of chandu smuggling, because every chest of opium exported from India to the Straits, and thence to the Malay States, can be traced through every step of its passage. A great deal of inferior opium is, however, grown in China, and attempts are sometimes made to smuggle this stuff into the colony and the Malay States.

As regards public gambling, which is permitted to Chinese, and always has been permitted in the Malay States, any one can supply reasons against it. To argue the question at length would be foreign to the purposes of this book. It is not necessary to do more than state briefly some of the causes why the British Advisers have supported the retention of the custom. First of all, the Chinese will gamble, whether the law 
allows or forbids it. The habit is inveterate and ineradicable with those who have the money to do it. With miners living in the jungle, with no sources of amusernent open to them and plenty of time on their hands, no power short of an incorruptible police constable, attached day and night to each Chinese, could stop it. The facilities for clandestine gambling, in such a country as the Malay States, are so great that if the practice were forbidden the law would be broken, with impunity, every hour of the day. The Protected Malay States began their new life with such straitened means that it was only possible to employ a police force just sufficient to deal with ordinary crime; the country is so large, the distances so great, the jungle so all-pervading, that the comparatively large force of police now employed is always overworked in its efforts to protect life and property, To have made gambling illegal, would have been to expose the whole police force to an irresistible temptation. They would have been corrupted and rendered untrustworthy in other and more important matters, while gambling would have been suppressed in name only. The Malay Rulers and Chiefs strongly objected to the introduction of measures to make public gambling illegal ; they said it was an old-established custom, they knew the evils which would certainly follow its nominal suppression, and they declined to sacrifice the revenue which was derived from sanctioning the practice under strict control. Therefore the gambling farm has been continued. It is only permitted in places and buildings approved by the police, and during very limited hours. It is to the farmer's interest to see that no other form of gambling is carried on, and his servants, not the police, are engaged in preventive work. There is no particular inducement, for the class of Chinese who indulge in this habit, to play in places other than those set apart for the purpose. All gambling is for ready money, and as the players are nearly all miners and the 
halls are public, the better-class Chinese in the Malay States go to the Colony-where gaming is illegal-when they wish to play. There of course a man can only indulge surreptitiously, but in the country house of a friend these things are easily managed, and there is the added attraction of risk. All forms of wha-wei, or Chinese lottery, are absolutely forbidden in the Malay States, and Government has the invaluable assistance of the farmer in suppressing them, because it is to his interest to do so and is also a condition of his contract. In the colony, on the other hand, it is admitted that these lotteries are always rife and do an infinity of mischief.

As was natural, an administration which aimed at developing the country for the benefit of the people gave early attention to the cause of education. The whole business of the country was carried on in Malay. Every one except the more newly arrived Chinese and Indians spoke it. It was the lingua franca by which white, and brown, and black, and yellow men exchanged ideas and did business; it was the language of the State councils and the courts, of hospitals and police stations, and of all Government departments in their dealings with natives of any nationality. Most of the courts and police stations, and many of the Government offices, gradually found it necessary to employ Chinese writers and interpreters, and, as the States advanced in prosperity and grew in population, Tamil and Hindustani interpreters have been added; but for all that, the general medium of conversation remains Malay. From very small beginnings, the Government established in all the States a system of vernacular schools, where Malay reading and writing, arithmetic, and some geography are taught. There are also schools of the same class for girls, and in both the teachers are Malay men and Malay women respectively. The Government has power by law to compel the compulsory attendance of children at an accessible vernacular school in any country 
district where parents neglect their duty. The education in all vernacular schools is free, and the Koran is taught in all Malay schools. In towns there are English schools with English masters, where the standard of education is much the same as that taught in similar institutions in the neighbouring British Colony. The most promising boys in the vernacular schools are helped, if they desire it, to pass on to a school where English is taught. In the centres of Chinese and Tamil populations there are Chinese and Tamil schools; but the children of these nationalities usually manage to attend a school where English is taught. There are also a few State-aided schools founded under the auspices of Roman Catholic, Methodist, and other Christian denominations. Special efforts have been made to provide a suitable education for the children of Malay Rajas and chiefs; but the Government has not aimed at educating the children of any class or nationality to unfit them for the lives they will probably have to lead. A critic might say that the Protected States have spent, and continue to spend, too small a proportion of their revenues on education. That may be so, but the results obtained are not unsatisfactory, and the Government has never desired to give to the children a smattering, or even a larger quantity, of knowledge which will not help them to more useful and happy lives than they now lead. To the Malay the principal value of school attendance is to teach him habits of order, punctuality, and obedience. Reading, writing, and arithmetic will always be useful to him; but beyond that, what the Government has tried to introduce are agricultural and technical schools and classes where a boy may learn the principles and practice of a useful industry. Unfortunately there is at present such a demand for clerks, both in and out of the Government service, that every intelligent boy who has passed one of the higher standards (not necessarily the highest) can at once secure remunerative employment. The consequence is that in- 
telligent boys leave school too soon, and very few of them can be found to devote themselves to a technical education. As in the Colony, the Native States offer every year a scholarship, which can be held for five years and is valuable enough to give the holder five years' teaching in a British University. Rightly or wrongly, the Malay administrations have tried to avoid a system likely to create an imitation, however remote, of the occasionally startling, sometimes grotesque, and often pathetic product of the British Indian schools.

I have referred to Sir Cecil Smith's interest in the cause of education. When he finally left the East in I893, he wrote as follows to the Marquess of Ripon, then Secretary of State for the Colonies :-

"Next, I wish to refer to the result of the policy regarding the education of the Malays for employment in the administration. This has been kept steadily in view as a cardinal feature in the government of the States, and has met with a considerable measure of success. Throughout the States there is an increasing number of Malays who, with 'hereditary or customary claims to office,' are being trained and are helping to educate themselves to take an active and responsible share in the Government. The importance of the policy referred to, whether as regards our simple duty towards the Protected States or as regards the expediency of doing all that is feasible to make the natives have the greatest interest in the welfare of their own country, cannot be overrated."

While mining was the important industry in all the States, the northernmost district of Pêrak, called Krian, was specially suited to the cultivation of rice. It is a coast district adjoining Province Wellesley; almost the whole of it is quite level, and it is drained by several considerable rivers. Prior to 1874 , a very small portion of this district, right on the coast, had been partially cultivated for rice; the rest of the district was unbroken 
jungle. In the years which followed, the entire district was, by the great exertions of Government officers, cleared, roaded, occupied by Malays and a few Tamils, and turned into an immense rice field. Dotted about are some sugar estates, owned by one European company and a number of Chinese planters. Low country ricefields depend for success on a supply of water when the fields are ploughed and the grain planted-or, to be more accurate, when the young plants are transferred from the nurseries to the fieldsand for some months later. The only water-supply in Krian was an uncertain rainfall which either made or marred the harvest. Moreover, the rivers were tidal, the water brackish, and the land so low and flat that, in a drought, the supply of drinking-water ran short, and the people were either compelled to leave the place or to run the risk of disease which not seldom developed into epidemic. By permission of the Sultan of Kĕdah, the Government of Pêrak obtained from some hills in Kĕdah territory a supply of drinking-water sufficient for the head-quarters of the district, but that of course did not supply the needs of the agricultural population miles away. Under these circumstances a scheme was, in I895, elaborated to create a lake (by the construction of works at a gorge in some hills through which a large stream forced its way), and thence to carry the water in a great canal, raised above the level of the surrounding country, and by side canals, at intervals throughout its length, to irrigate nearly seventy thousand acres of rice land and supply the cultivators with drinking-water from the same source.

Mr. Claude Vincent, of the Indian Public Works, was deputed, on special service, to visit Pêrak and report on the scheme prepared by the Department of the Pêrak State Engineer, Mr. F. S:. George Caulfeild. The scheme was approved, with some alterations, has been under construction ever since, and was only lately completed at a 
cost exceeding $£_{150,000}$. There has been great delay in carrying out this work, but the difficulties were also great. The estimates made, from time to time, of the probable cost of the work have been largely exceeded, but the benefits to the district will justify the outlay, and a water-rate should give a moderate interest on the capital expended.

With the advancing prosperity of the country, the rapid development of new and old mining fields, and the construction of roads and railways, many populous towns sprang up, and the Government expended large sums of money in supplying them with pure water. In many cases it was necessary to construct considerable headworks, and in all the water is conveyed long distances, from the source of supply to the centre of distribution. Kuala Lumpor, in Sělangor, is lighted by electricity, and other Malay towns will, in time, be similarly provided. There is no coal and no gas in the Malay States, and all lighting has hitherto been done with imported mineral oil.

Tin-mining has enabled the administration to rapidly open up and develop a country which, thirty years ago, was practically covered by virgin forest. It was the clear policy of the Government to encourage the mining industry by every legitimate means, and though, for twenty-five years, Europeans have been prophesying the exhaustion of the alluvial tin deposits, I have never shared that view, and the production is to-day larger than ever, and likely to continue for many years to come. Still, no effort has been spared to secure a settled population of agriculturists, and what has been accomplished in the Krian district of Pêrak is a striking proof of success. Rice and cocoanuts are probably the two forms of cultivation best suited to Malays. The Chinese are successful sugargrowers, and years ago the Government introduced into Pêrak the cultivation of the pepper vine, and that is an 
established industry. The Government also endeavoured to introduce silkworms, but the experiment met with indifferent success. While Resident of Pêrak, Sir Hugh Low started Government plantations and gardens, at high and low levels, and large sums were expended on the introduction and cultivation of Arabian coffee, cinchona, tea, and rubber. The cinchona failed, but very fine qualities of Arabian coffee and tea were grown, and the suitability of the climate and soil having been proved, these estates were sold or abandoned. Having regard to the importance which the cultivation of rubber has now assumed in the Malay States, it is interesting to record here the following passage from a report written by Sir Hugh Low so long ago as July, 1883 :-

"All kinds of india-rubber succeed admirably, and seeds and plants of Hevea Braziliensis have been distributed to Java and Singapore, to Ceylon and to India, and supplies will be forwarded on application to any person or institution which will take care of these valuable plants."

In the report which Sir Hugh Low wrote in February, I 884, just before taking leave to England-a leave lasting nearly two years-he said: "Specimens of the rubber from six years old plants of the Hevea Braziliensis, in the Government experimental gardens, have also been collected, as well as of that from the Manihot Glaziari (Ceara Scrap), and will be sent to England for report."

A little further on, in the same report, Sir Hugh Low wrote: "British capitalists have, with the exception of the enterprising merchants from Shanghai, as yet done little or nothing in Pêrak; a feeble commencement only being yet apparent on the part of two concessionaries from Australia, to whom large grants have been given." Those grants were for mining land, and it is worth remembering that British capitalists declined to risk even small sums in the Malay States till years after the enterprise and 
industry of the Chinese had established and developed the mines, and the Government had, in their experimental plantations, proved the capabilities of the soil. It is also highly interesting to note that nearly thirty years ago a Malay State not only imported and successfully cultivated Para rubber, but even distributed plants and seed to Java and Singapore, to Ceylon and India; though no one then thought it worth his while to cultivate rubber, either the indigenous (such as Ficus elastica) or the imported varieties. Whilst in Pêrak in I884-5 I planted four hundred seeds from Sir Hugh Low's trees, and in due time the seedlings were planted out. Those trees yielded a great quantity of the seed from which the Hevea plantations of Malaya were formed.

It has been stated that narrow-minded directions from Singapore discouraged Ceylon planters for a while, but when efforts were made to repair the mistake and land was granted on very easy terms, a number of experienced men settled in all the western States, especially in Sělangor, and there took up the serious cultivation of Liberian coffee, which then promised exceedingly well. The venture, in the hands of these able and determined men, was quite successful, but almost as soon as the trees began to yield a crop the price of coffee fell to almost one-third of what it had been, and all hope of fair profit depended upon a greater recovery in price than has yet taken place. It was a very trying time for men who had put almost, or quite, all they possessed into the land, but the Ceylon planter has won a reputation for "grit" and resource which places him very near the head of his profession. Times were very bad indeed for some years: prices were hopeless, unforeseen enemies attacked the coffee trees, labour was scarce, and funds were almost exhausted. At this crisis the planting of Para rubber was taken up, first on a small, but very soon on a rapidly increasing scale. Those who began the movement have nothing to 
regret, except their own caution, or the limitations imposed upon them by want of capital. Now, every one understands the value of an acre of Para rubber in the Malay States, and what profit it will yield at seven, fourteen, and twenty-one years of age. The real difficulty is to believe the facts which can no longer be questioned, but, at present prices, an acre of land planted with 108 Para rubber trees, should, when the trees are seven years old, yield a profit of $£ 20$ an acre; when the trees are fourteen years old they might give a profit of $£ 80$ an acre, and from over twenty years onwards a profit of $£ 150$ an acre is possible. Possible, but very unlikely, because, though a given tree of a certain age has yielded so many pounds of rubber in a year, it is hardly conceivable that every tree on an acre of land will give a similar quantity. A very reasonable estimate will, however, show a more than satisfactory return. These estimates do not allow for the payment of any export duty, and the Government of the Federated Malay States at present imposes a duty on exported rubber of $2 \frac{1}{2}$ per cent ad valorem, and can, of course, vary these conditions in the future alienation of land.

The following extract from a report by the Acting British Resident, Pêrak, dated 15 April, 1901, shows that the above estimates are not extravagant, for the present price of the best plantation rubber is about $6 \mathrm{~s}$. the pound.

"The result of a sale in the London market of a parcel of Para rubber was received early in the year: $327 \mathrm{lb}$. of the best quality rubber fetched 3 s. rod. per pound, and $23 \mathrm{lb}$. of scrap, i.e. fragments of rubber picked off the stems of the trees after tapping, were sold at the rate of 2s. 6d. per pound. Eighty-two trees of an average age of fourteen years were tapped to give this result; the yield is thus a little over $4 \mathrm{lb}$. to the tree, but the Superintendent, Mr. Derry, reports that exceptionally heavy rains 
frequently interrupted the work, and threatened, in conjunction with the tapping, to damage the seed crop, and that therefore the tapping was stopped in many cases long before the supply of latex was exhausted. From the eleven best trees over $97 \mathrm{lb}$. of dry rubber were obtained, one tree yielding $\mathrm{I} 2 \mathrm{lb}$. $\mathrm{I} \frac{1}{2} \mathrm{Oz}$. A small sample of gutta ramboug (ficus elastica) was reported on in England as 'good clean Java character,' and sold at the rate of 3s. rod. per pound. A tree in the Kuala Kangsar garden yielded $25 \mathrm{lb}$. at a single tapping; this tree is nineteen years old and about 90 feet high; measured round the aerial roots, at 3 feet from the ground, it has a girth of 88 feet."

The following interesting particulars are from the latest report of the Director of Agriculture :-

"Last year's production in the Federated Malay States may be estimated at 300,000 lbs. The total world's consumption as found in the official statistics of net imports of the seven great rubber-consuming countries-viz. United States, Germany, Great Britain, France, Belgium, Austria-Hungary, and Italy-was I37,530,458 lbs., or 61,397 tons. These official figures fall short of the total world's consumption probably as much as 15 or 20 per cent., but if we take these approximate figures we find that the Federated Malay States in 1905 produced $\frac{1}{200}$ th part of the world's consumption.

"Taking the area planted in the Federated Malay States, on Ist January, 1906, at 40,000 acres, this will give us at 100 lbs. per acre in I9I2 a yield of $4,000,000 \mathrm{lbs}$, or 1785 tons, that will be if the consumption remains stationary $\frac{1}{3 \frac{1}{4}}$ th of the total consumption. But the world's consumption as shown by official statistics is :-

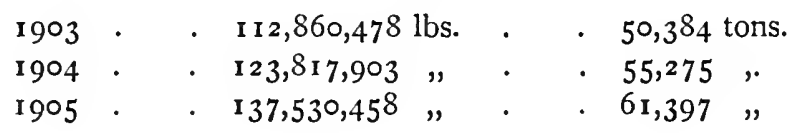


an increase of 10 per cent. roughly per year, so that in I9I 2 we may expect at the same rate of increased consumption 70 per cent. more than in 1905-i.e., a demand for and perhaps a supply of $232,288,000$ lbs., or 103,700 tons, and of that we could only supply $\frac{1}{58}$ th part.

"Thus, as far as statistics show, the price of rubber is not likely to seriously decrease owing to over-production, and very much larger areas will have to be planted before the production is in excess of the demand."

In very early days the Pêrak Government established at head-quarters a museum of Malay flora, fauna, minerals, grain, implements, weapons, dress, pottery, artwork of all kinds, and, indeed, everything Malayan. The institution was admirably managed by Mr. Leonard Wray, I.S.o.; it has proved most useful and most instructive to all classes and nationalities, and it will bear comparison with any museum in the East. A similar museum was begun many years ago in Kuala Lumpor, and has lately been placed under Mr. Wray's direction.

Wherever the Englishman goes he carries his sports, and Malaya has been no exception to the rule, but rather the contrary.

At first the officers were too few for any kind of combined game; they were too scattered; the country was jungle and had to be cleared; and there was no leisure for amusement. Gradually some European ladies joined the exiles, and it became politic, if not absolutely necessary, to supply, at the head-quarters of each district, a readingroom where all Europeans could find journals and books, and where they could meet on common ground. The Government supplied the buildings and contributed an annual subscription, and the members did the rest and undertook the management. Billiard-tables, cricket, football, tennis, and hockey grounds were added as the European population grew and funds were available. In a country where there are no places of public amusement 
these clubs have supplied a very useful and civilizing element, and the Government has no need to regret the comparatively small amounts expended on providing healthy recreation for their officers, and for all those who have benefited by this somewhat unusual generosity. It is, however, very doubtful whether those who obtain a large amount of amusement at very small cost properly appreciate their good fortune. In the most populous towns, where the European community is sufficiently numerous, they have founded other clubs, of much the same character, at their own expense. Race-courses and golf-courses are now to be found in all the western States.

As a further means of preserving the health of their officers, in a very relaxing and not always healthy climate, the Government established hill bungalows at various elevations, from 1500 to 4500 feet above the sea. Short visits to these stations (which enjoy a temperature varying from $60^{\circ} \mathrm{F}$. to $73^{\circ} \mathrm{F}$.) have saved many a man a long and expensive journey to Europe. It is, however, not unusual for Europeans, Eurasians, and natives to visit Java, India, China, and Japan for health and amusement. In the centre of the main range of Malay hills there are about 100,000 acres of undulating country at a height of 4000 feet, and it is probable that in time a large station may be established there, more especially if planters find that the soil is suitable for profitable cultivation. The highland referred to, originally explored by Mr. W. Cameron under Government auspices, is less than forty miles from a point on the Pêrak trunk railway.

For many years an adequate supply of coin was a serious difficulty in the Malay States. The Mexican dollar, the Japanese yen, and later the British trade dollar, with the Straits Settlements small silver and copper coinage and the notes of the Eastern chartered banks, were the recognized currency. The supply of 
notes, silver, and copper was often quite inadequate to the needs of a rapidily advancing country, and great inconvenience was the rule rather than the exception. For sixteen years I urged the issue of Government notes, but the first reply was that such a proposal was premature, because neither the Straits Colony nor Hong-Kong possessed a note issue of its own. I could not quite see that the argument was very convincing, but later I understood that the Imperial Treasury raised some objection to the proposal. In the end the Straits Government issued the notes, and the Malay States were not allowed to share in the profits of the transaction, though a proportion of the profits of the Straits copper and subsidiary silver coinage has been granted.

Another instance of the curious application of the view that venerable theories must not be interfered with is worthy of mention. The terrible disease leprosy is not indigenous in Malaya, but Chinese lepers have for years passed into the Malay Peninsula, and in an up-country district of Pêrak a few Malays contracted the malady. Years passed and it was noticed that the number of Malay lepers was steadily increasing, so that when a census of them was taken, it was found that there were close upon a hundred Malay lepers of both sexes and all ages. Malays have a great horror of, and loathing for, this terrible disease, and as they, and the best authorities locally available, were convinced that all those afflicted had contracted the malady by contagion, the Pêrak State Council passed a measure to compulsorily segregate the lepers in an uninhabited island at the mouth of the Pêrak River. It was also proposed to allow any of their relatives who desired it to accompany the lepers to the island and remain there. This enactment was, as customary, forwarded to Singapore and transmitted to the Secretary of State for the Colonies. In due time orders came from England disallowing the measure and stating that as the 
Royal College of Physicians had decided that leprosy is not contagious, the proposals of the Pêrak Government could not be sanctioned, but that any lepers who desired exile on the island might have their wishes gratified. Voluntary segregation is not popular with lepers, and it was not considered advisable that the Government should go to the expense of erecting buildings to house patients who would never occupy them; but the Malay members of Council suggested that the lepers might be sent to England, where they could do no harm, while Pêrak would be free of them. Fifteen years later a circular from the Colonial Office stated that as the high medical authorities in England had changed their minds, and now consider that leprosy is contagious, there would be no objection to the compulsory segregation of the unclean! In those fifteen years, of course, a number of poor wretches had contracted the disease. It is only another instance of the advisability of letting people who live eight thousand miles away, under somewhat different conditions, manage their own domestic affairs without foreign interference. Mistakes made locally, in such cases, are paid for locally; but if the mistake is made at a distance, it still has to be paid for locally. ${ }^{1}$

An invasion of all sorts and conditions of men and women brought with it many evils to which the Malays, as a people, had hitherto been strangers. The drinking of intoxicants was one, and others will occur to the reader. Malays of all classes, and especially of the higher classes, felt these things very strongly, and wished to legislate to prevent the evil and, where possible, to cure it; but because the conditions of life in England are totally different, and what was proposed to be done in Malaya would not be sanctioned by public opinion if done here, the Malay has to accept the imported horror, and is not allowed to protect

1 See p. 334, note. No effort has been made to look for instances to support this statement, but one has come very recently without seeking. 
himself, his family, and his people, for whose benefit alone he wishes to legislate.

Reference has been made more than once to Păhang. It is a very large State on the east coast of the Peninsula, and in 1888 had a population of about fifty thousand Malays and a few hundred Chinese. The State was supposed to be very rich in gold, less so in tin. But it was undeveloped and unregenerate ; the Government was despotic, the Raja Bĕndáhâra being the despot, and the people suffered in the ways described in the earlier chapters of this book, only rather more so in Păhang than elsewhere. It may be said that that was their misfortune, and not the concern of any one outside Păhang. Possibly matters might have remained as they were to this day, but a British subject was murdered in Păhang under circumstances which made the responsibilities of the ruler so manifest that Sir Cecil Smith, then Governor of the Straits, felt compelled to demand explanation and satisfaction. The explanation was altogether unacceptable, and, as satisfaction was not forthcoming, it seemed that there must be serious consequences. The Bĕndahâra, however, mainly owing to the advice of the Sultan of Johore, expressed his regret for what had occurred, and asked for the appointment of a British Resident. This request was granted, and in October, 1888 , Mr. J. P. Rodger (now Sir John Rodger, K.C.M.G.) was appointed Resident of Păhang, while Mr. Hugh Clifford, who had already spent some years in Păhang as Governor's agent, remained there to assist the Resident. The size of Păhang made it unwieldy, and the fact that during the prevalence of the north-east monsoon, from October to April, the shore was almost unapproachable for steamers, severely handicapped the country as regards development. There were many important chiefs, and only a small revenue from which to give them suitable allowances and provide for the costs of the most economical administration. To 
add the last straw, some chiefs took up arms against all that the new regime stood for, and the consequence was a long, a harassing, and an expensive "war," which was only brought to a conclusion by hunting the rebels out of Păhang and even following them into the independent neighbouring States, Kelantan and Trĕnggânu, where they were eventually secured, mainly by the efforts of Mr. Hugh Clifford. Some of the rebels lost their lives in these prolonged operations, some were done to death by the Siamese who took part in their arrest, and the remainder were deported to Siam, where a number of the survivors remain to the present time. 


\section{CHAPTER XII}

\section{I $895-1906$ \\ FEDERATION AND ITS RESULTS}

I

N I896, Colonel Sir Charles Mitchell, K.C.M.G. (afterwards G.C.M.G.), was the Governor of the Straits Settlements, promoted thither from Natal. The writer; in Sělangor, Mr. (now Sir William) Treacher, C.M.G.; in the Nĕgri Sambilan, the Honourable Martin Lister ; and in Păhang, Mr. (now Sir John) Rodger, C.M.G.

Before the departure of Governor Sir Cecil C. Smith, in I893, I had, for the reasons given in the previous chapter, and for others needless to mention, drawn up a scheme for the federation of the four States, and submitted it to him. This proposal was forwarded for the consideration of the Secretary of State for the Colonies, and Sir Charles Mitchell went to the Straits with instructions to report as to the advisability of adopting the suggestion. Sir Charles Mitchell, after nearly two years' consideration, recommended that, if the Malay Rulers favoured the proposal, federation should be adopted. Mr. Chamberlain approved, and, acting on instructions, I visited the several States, explained the scheme very fully to the Malay Rulers and British Residents, and secured the written consent of the former and the verbal concurrence and entire sympathy of the latter. In a month the question was settled, and the new departure was formally inaugurated on I July, I 896 ; since which date the four Protected States have been federated under one administration, with a Resident-General in control, the Residents remaining, as before, the chief 
executive officers in each State, while every important department was placed under one federal head, who is responsible to the Resident-General for uniformity of system in all the States.

The Treaty of Federation was a very short document, and what it did was to make the States one for all general purposes of administration; but, in agreeing to the appointment of a Resident-General, it was for the first time plainly stated that he should have executive control, under the direction of the Governor of the Straits Settlements, who would in future be also styled High Commissioner for the Federated Malay States.

The Malay rulers cordially approved this scheme, because it did not touch their own status in any way, though it formally recognized the right of the Resident-General to exercise a very large control in the affairs of the States. He was not styled an adviser; his authority, both in the general administration, and as regards the Residents, was clearly defined. Then the Malay Rulers believed that, as a federation, they would be stronger, more important, their views more likely to receive consideration, should a day come when those views happened to be at variance with the supreme authority, be it High Commissioner at Singapore or Secretary of State in England. Two of the States, Pêrak and Sĕlangor, were then very rich; Nĕgri Sambîlan had a small debt, but was financially sound; while Păhang was very poor, owed a large sum to the colony, and, though believed to be rich in minerals, had no resources to develop the country. By federation, the rich States were to help the poor ones; so Păhang and Nĕgri Sambilan hoped to gain by the arrangement, while the Rulers of Pêrak and Sĕlangor were large-minded enough to welcome the opportunity of pushing on the backward States for the glory and ultimate benefit of the federation.

Further, they welcomed federation because it meant consistency and continuity of policy. It meant the aboli- 
tion of inter-state frictions and jealousies, and the power to conceive and execute great projects for the benefit of the partnership, without reference to the special interests of any partner. Above all, they not only accepted but desired federation, because they believed that it would give them, in the Resident-General, a powerful advocate of their needs and their views, a friend whose voice would be heard further and carry more weight than that of any Resident, or of all the Residents acting independently. In the past, there had been times when they had had experience of the result of references to the Governor in distant Singapore, when the representations of their Residents carried little weight if opposed by an authoritative voice giving different counsel to an inexperienced or not much interested Governor. They foresaw that the future would accentuate the disadvantageous position of the States; for the tried and experienced men would go, and their successors might not be able to command even as much influence in Singapore or Downing Street as those who had helped to steer the Malay craft through the troubled waters of the seventies into the calm of the nineties. Therefore, the Malay Sultans and Chiefs, whether they were clearly to gain by the new arrangement or apparently to lose-at least for a time-unanimously declared for federation.

It was perhaps more curious that the four Residents were equally in favour of a proposal which seemed likely to deprive them of some authority and status. Speaking of the others, I can say that, whilst quite alive to that view of the position, they cordially favoured federation because they realized that the existing arrangement was unsatisfactory and becoming impossible, while federation must make for unity of purpose and effort, for efficiency, for progress, for help where it was most wanted, and for a government no longer of one man but of five-the Resident-General and the Residents-with all the best special advice which federation could attract to the 


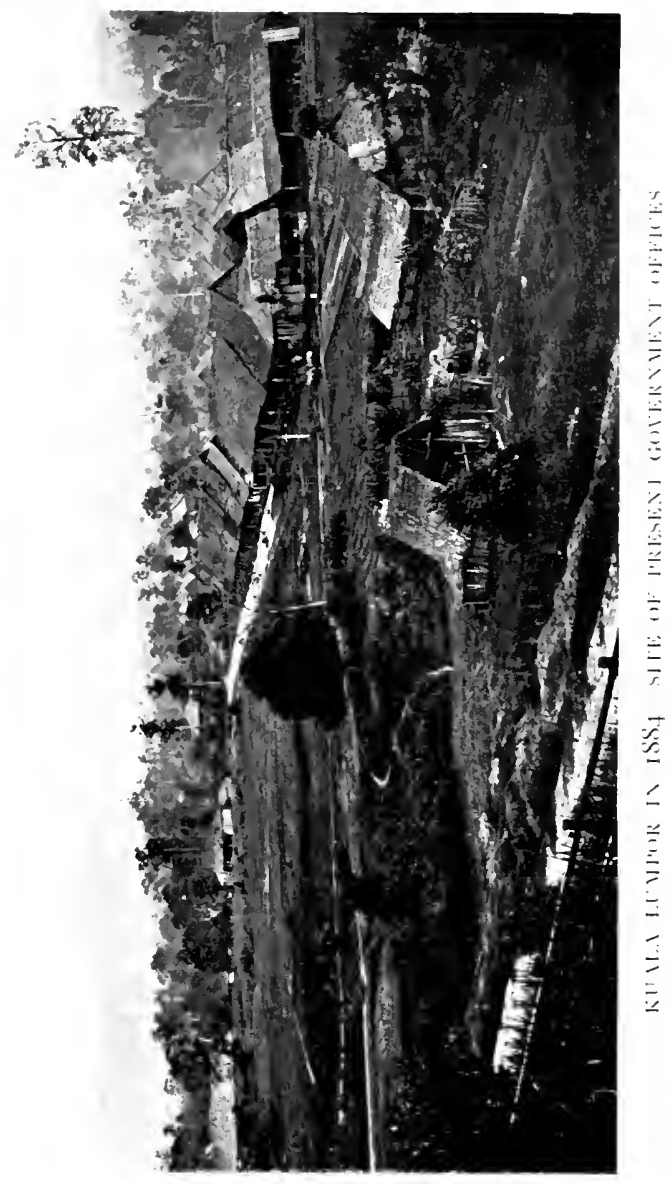



service of the Malay States. The Residents of those days, or some of them, would have liked to see the Resident-General independent of the Governor at Singapore, and in direct correspondence with the Secretary of State for the Colonies. That idea went no further, because it was thought likely to meet with so much opposition that the rest of the scheme might be wrecked in one general condemnation. In order to ease possible friction, and to put the High Commissioner (supposing him to be a stranger with no experience of Malay matters) in a position to exercise something approaching effective control, the federation scheme provided him with a Secretary to be selected from the best of the rising men of the Malay States service-some one who knew not only the work of all the States, but possessed a knowledge of the Malay language and people and men of other nationalities, Europeans and Chinese, engaged in the development of the Malay States. The reader will understand the necessity for such an arrangement, when it is stated that the Federated Malay States are more than ten times the area of the colony, with a larger population, and a revenue and a civil service each about three times as large as those of the Straits Settlements.

As soon as federation was accomplished, Kuala Lumpor, in Sĕlangor, was, because of its central position, selected for the head-quarters of the Resident-General and of the heads of the Federal Departments. The writer was appointed Resident-General, and at once moved to Kuala Lumpor and began to organize the new form of administration. Mr. T. Kershaw was appointed Legal Adviser, Mr. G. T. Hare Secretary for Chinese Affairs, and the work these two officers did for the Malay States in the next few years was beyond all praise. On Mr. Kershaw devolved the labour of drafting all the legal enactments which, from this date forward, had to be passed in practically identical form by the Council of each State in 
the Federation, while Mr. Hare visited every Chinese mine, plantation, and village throughout the four States, established a unique influence with the Chinese of all classes, wrote most valuable papers on every subject concerning the Chinese community, and obtained such a thorough knowledge of the Revenue Farm System and the methods and profits of farmers, that the Government was enabled, probably for the first time, to secure an adequate rent, and the receipts from this source increased enormously. Mr. Kershaw was compelled to retire from ill-health, no doubt largely due to his unflagging toil, and Mr. Hare died in Singapore a few months ago.

To the public, especially to Europeans working in or having any relations with the Malay States, one of the most notable results of the new regime was the appointment of a Judicial Commissioner (Mr. Lawrence Jackson, Q.C.) to try capital cases and appeals from the courts of the senior magistrates, whose jurisdiction, as well as that of other officers entrusted with magisterial powers, was reduced in accordance with a plan for the re-arrangement of judicial duties throughout the Federation. For the first time also, members of the legal professicn were admitted to plead in the Malay States Courts, ard rules of procedure were framed by the Judicial Commissioner. The jury system was not found to work satisfactorily, and it was abolished in favour of trial by a judge with assessors. Within the last few years the judicial system has been further remodelled and the Bench strengthened by the addition of two Assistant Judicial Commissioners. A Public Prosecutor has also been appointed to relieve European police officers of the work of getting up important cases and prosecuting in the various courts.

The various police forces were entirely reorganized under a Commissioner of Police (the late Mr. H. C. Syers), and Colonel Walker, C.M.G., undertook the task of forming a regiment of Sikhs and Pathans named the Malay States 


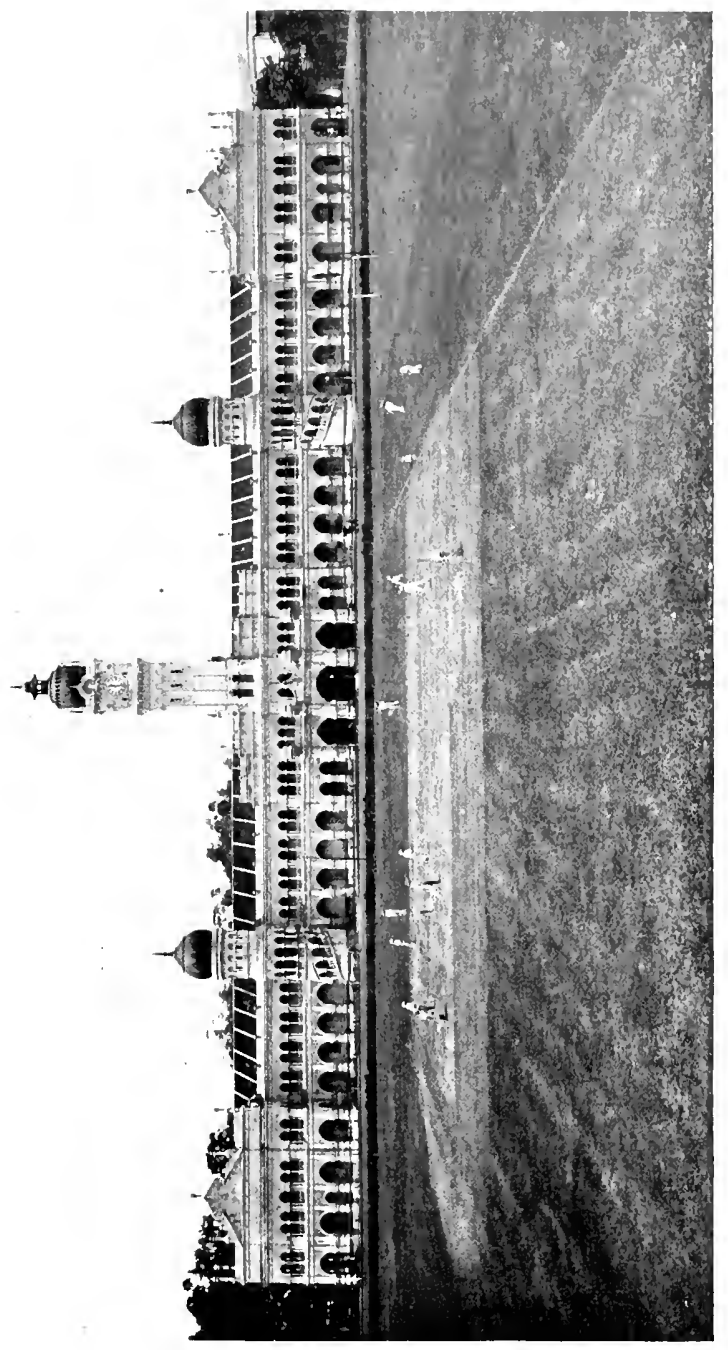

告 



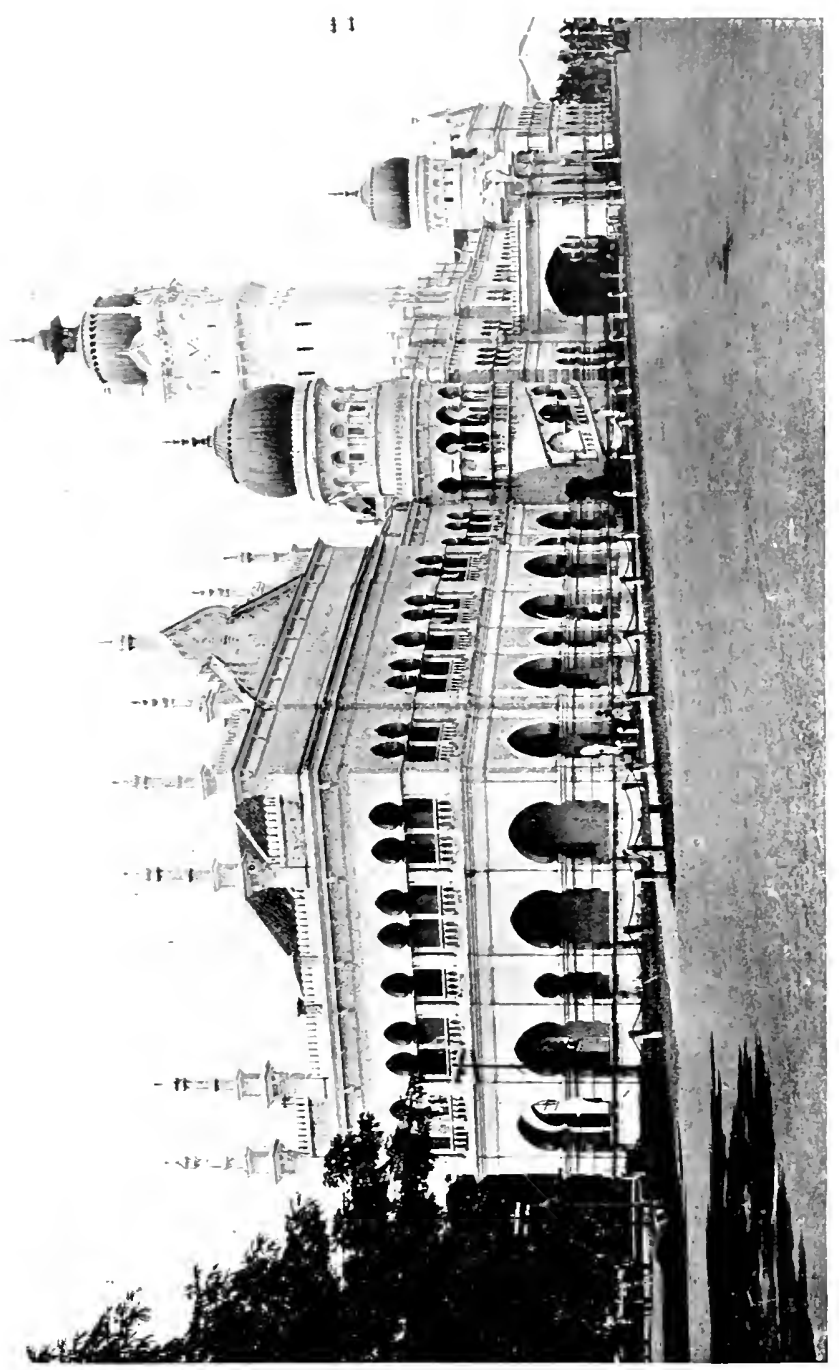

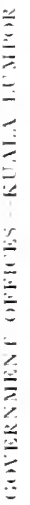



Guides, which has been brought to such a high state of efficiency that last year in the general musketry competition open to all the regular troops and volunteers in the colony and Federated Malay States, the Warren Shield was won for the fourth year in succession, five companies of the regiment coming first on the list.

The Malay States Guides (900 strong) only accept recruits who satisfy a very high standard; the officers are, in most cases, seconded from the British Army for a term of years; and the regiment is always ready to start on active service, with stores, clothing, and equipment, at a few hours' notice. Officers and men have always volunteered for active service whenever there was an opportunity, and it is much to be regretted that they were not employed during the operations round Peking in I900-I, when they were so much nearer the scene of action than the troops sent from India. The refusal to make use of them is all the more difficult to understand because the Imperial Government counts upon the Malay States Guides as a force which can be utilized to strengthen the garrison of Singapore in case of war between Great Britain and any foreign Power. It seems, therefore, short-sighted to have neglected any opportunity for proving the fighting value of the regiment. The head-quarters of the regiment are at Taipeng, Pêrak, on the main trunk line of railway, fifty miles south of Pinang.

The police force, which is now over 2300 strong, is composed of Indians and Malays; the former are found useful for guard and town duties and to deal with Chinese, while the Malays do best in coast stations and rural districts, especially where the population is mainly Malay. All the senior officers are British, and they now form, with the Straits and Hong Kong, an eastern police service; candidates must pass a competitive examination on entry, and undergo a special training to fit them for their duties. As these officers gain experience of the country, 
the people, and their own duties, it may fairly be expected that this important department will increase in efficiency.

A financial commissioner was appointed, and the whole financial system, both as regards treasuries and audit, was reorganized, at some increase in expenditure, but with much more satisfactory results in uniformity of method and the prompt rendering of accounts. Similarly, the Public Works Departments of all the States were formed into one, under a director (Mr. F. St. G. Caulfeild, I.S.O.) responsible to the Resident-General for the timely submission of all new proposals, the preparation of all plans and estimates, and the due execution of approved schemes. The personnel of the department was rearranged and graded, with a new system of salaries, and instructions were drawn up exactly defining the duties of all members of the staff. So with the railway. The whole work, whether construction of new lines or management of those already working, was placed under one guiding hand, who in this case was styled general manager, to meet the wishes of the Colonial Office, though the more appropriate title would be Director of Railways. At the time when federation was adopted there were disconnected sections of railway in all the States, and the most important work then in view was to join them up and secure a main line from the Prai River, in Province Wellesley, right through the greatest agricultural and mining districts of Pêrak, to join the Sělangor main line and continue it to Seramban, the head-quarters of the Nĕgri Sambillan administration. This work was rapidly and very satisfactorily carried through by July, I903, under the direction of Mr. C. E. Spooner, C.M.G., the head of the railway department. Since that date the Federated Malay States have continued their own line to the borders of Johore ; they have supervised the building of a branch line for the colony from the borders of Malacca and the Nĕgri Sambillan to the town and port of 
Malacca, and they are now constructing an extension of I 20 miles from the boundary of Negri Sambilan and Johore, right through the latter State to its capital, Johore Bhâru, exactly opposite the terminus of the Singapore Railway on the other side of the Johore Strait. This Johore State Railway is not only being built by the Railway Department of the Federated Malay States, the whole cost is being advanced, as a loan to Johore, out of the surplus balances of the Federation, just as the Province Wellesley Railway and the Malacca Railway, in the British Colony of the Straits Settlements, were built and paid for by the Federated Malay States.

I am responsible for the Malay States lines, with the exception of the eight miles branch in Lârut, from Taipeng to Port Weld, and the twenty-four miles branch in Sungei Ujong, from Seramban to Port Dickson (which was built by and belongs to a private company), and I may recall the fact that when I first recommended the construction of the Province Wellesley line it was disapproved. But when 1 again repeated all the arguments in favour of the work and pressed to be allowed to undertake it, Mr. Chamberlain, then Secretary of State for the Colonies, gave his sanction on the ground that, if the value of a great work could be satisfactorily demonstrated, the sooner it was taken in hand the better. Mr. Chamberlain is one of the few public men who realize this principle. Nothing is so common as to express great interest in a new proposal, great sympathy and even high approval ; but when it involves the expenditure of money, the running of risk, the acceptance of responsibility, enthusiasm for the scheme is not only tempered, but often entirely counteracted, by the decision to put off its accomplishment to the Greek Kalends.

The Malay States made, and paid for, the Province Wellesley Railway, and no benefit so great has ever been conferred on Pinang in the history of that Settlement; 
but the people of the place were slow to appreciate the fact, and have never been demonstrative in thanks to the Malay States, which also lent them a large sum of money to complete their steamer pier, another public work the advantages of which escaped their foresight.

The reader will understand, from what has already been said, that the Malay States were, at first, only places whose nominal rulers had so failed to keep their houses in order that their unruly subjects had become a danger to neighbouring British Settlements, and for the safety of those Settlements, the Queen's Government sent "advisers" to strengthen the hands of the Malay chiefs and assist them in establishing peace and good government. Of course, the Malay States were not British possessions, and could not be so treated; but, as matters settled down and the States began to prosper, they required many servants and much material which could best be supplied from England. For the selection of servants and the purchase of material the Residents were instructed to apply to the Crown Agents for the Colonies, and to them alone, and the Malay States are under a debt of gratitude to the Crown Agents for the great and valuable assistance given by them in trying to satisfy the multitudinous requests of rich and rapidly developing territories. Still, the Malay States were not like Crown Colonies, or any other dependencies of the British Empire, and they possessed and exercised a larger measure of authority than other countries even remotely connected with the Colonial Office. To take one instance alone: they began, completed, and from time to time extended their railways without reference to any one but the Governor at Singapore. The work was initiated in the Malay States, and carried out by engineers in the service of those States, from the first trial surveys to the public opening and working of the lines, without any assistance, except an occasional reference to the consulting engineers 


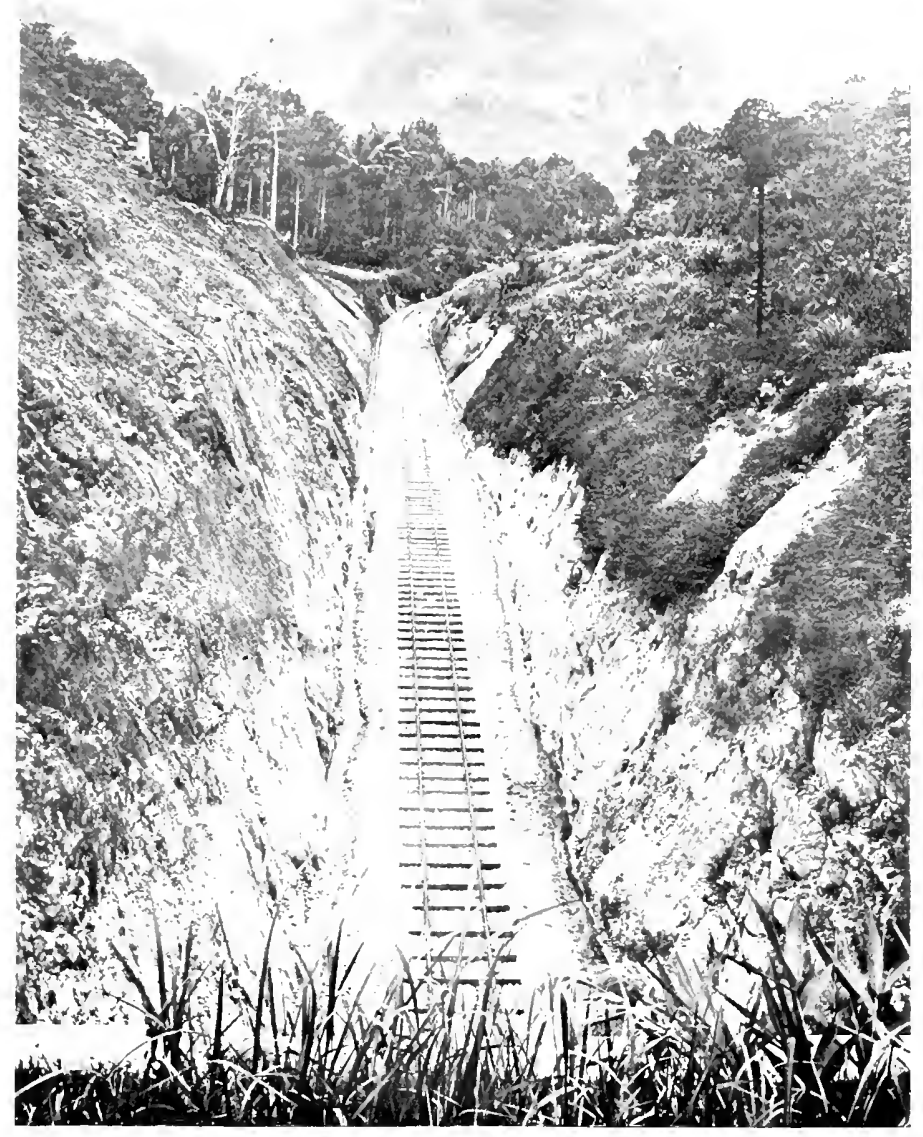

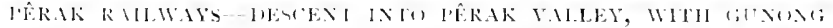
PUNAK, 2,000 FEEI IIIGII 

when advice was required on any matter of unusual importance, such as a design for a large bridge. All rails, locomotives, and other rolling stock, iron bridges, machinery, etc., were, however, purchased through the Crown Agents, and in these matters they constantly referred to the consulting engineers, whose advice was almost invariably followed. Therefore, as time went on, the gentlemen selected by the Crown Agents to advise them on railway matters (and no dependency is allowed to choose its own consulting engineers) became more and more interested in the Malay States railways, and as their work increased the Malay States recognized the position in a generous spirit. After nearly twenty years of successful railway construction, so successful that the severest criticism by qualified professional men is that the open lines are "too good" (meaning thereby that the gradients are, to use commonplace terms, needlessly flat, the curves needlessly wide, and all the works and buildings of a rather expensive character), the Colonial Office, or the Crown Agents, or the consulting engineers, awoke to the fact that the Malay States had been doing something quite novel, quite contrary to established custom, and therefore quite wrong. It appears that Colonies - that is, of course, Crown Colonies, responsible Governments do as they please, and do not employ the Crown Agents-are not supposed to possess engineers qualified to construct railways; and, as a rule, it may be granted that that is a very proper supposition. Therefore there is an "established system" for the construction of Government railways in these places, and that system is, that the consulting engineers to the Crown Agents undertake the whole job. They select, survey, and set out the line, appoint as many engineers as they think necessary, and send them out to do the construction on salaries fixed by them or in consultation with the Crown Agents. They decide the weight of the rails, the type of the bridges and rolling-stock, purchase the 
whole of the materials, and, when the line is completed, they inform the Government of the colony for whom it is made, whose only concern is to pay the bill. The advantage of this system is that the line is made-in time-and neither the colony's chief engineer, nor its Governor, nor its Executive or Legislative Council, have any real responsibility for the work, even though it takes twice as long to construct as the time originally estimated and costs twice as much. As the construction engineer is serving his masters in England and not the Colonial Government, it is difficult to interfere with him; and as the colony has no concern with the railway till it is finished and handed over, it is no one's busines to criticize. Moreover, if there is no one in the colony capable of constructing the railway, it is difficult to suppose that local criticism can have any value.

The objections to this "established system" are, that the work is executed thousands of miles from the people who are responsible for it, who very probably have no personal knowledge of the local circumstances, of the effects of climate and rainfall, of labour conditions, of local prices, of the usefulness or otherwise of local materials under certain conditions common in railway construction, of the resources of the place, and so on. The engineer in charge of the work is probably equally at sea until he has been many months in the place and bought his experience-at the cost of the local government. Then, as already explained, the local government cannot interfere, cannot be always raising questions only to be asked to give its full reasons in writing, and perhaps, eventually, have to explain what title it has to offer an opinion on technical points. However much the time, or the estimated cost, of the work are exceeded, no one is responsible. The Secretary of State, of course, only insists on the system; beyond that he washes his hands of the matter. The Crown Agents have clearly nothing to do with it; the 
whole business only gives them trouble. The consulting engineers cannot be held responsible if there is more rain, or more sun, than they expected at any particular time; nor are they held responsible if their representative in the colony finds it impossible to get labour, or sleepers, or any other local commodity, at the prices named in the estimates. If a bank is washed away because the waterways were not large enough to admit the passage of storm-water, or if a bridge tumbles down because the foundations were not properly constructed, the people in England cannot be made to suffer; and as for the engineer in charge, the utmost that can be done is to dismiss him, and he is not serving the Government, but the consulting engineers.

Worst of all, the consulting engineers, as such, disappear and are replaced by construction engineers, who pass the work of their own man, or of the contractors they employ; being placed in the invidious and (to the Government) unsatisfactory position of having to sit in judgment on their own plans and estimates carried out by their own servants -men who probably have to look to them for future employment.

Therefore, whatever the kind of work put in, the Government has to accept it ; whatever the bill, the Government has to pay it ; however the estimated time of construction is exceeded, the public must bear it patiently; because this is the established system under which railways are made in Crown Colonies. It might almost be added that, unless a man believe in the system faithfully, he cannot be saved.

Well, after nearly twenty years of another method, that of local responsibility and construction by Government engineers under the eye of the Government, which sees that it is getting its money worth, calls in other opinions when necessary, and takes care that all the conditions required by local circumstances shall be fulfilled in every 
particular; after that experience, crowned by a very marked success, not only as regards the quality of the roads constructed, but also in profits earned on the open lines, it was urged that the Federated Malay States should give up their methods and adopt in future the system enforced in Crown Colonies where the circumstances are different. Naturally the Malay States preferred the plan they understood, which had served them so well in the past, and which no one suggested had failed in any particular. On public grounds it is probably fortunate that the change has not been insisted upon, for the Malay Rulers understand questions of this kind better than might be supposed, and they would have resented the introduction of a system the need for which must have been difficult to explain. Malays do not lack intelligence, if they have no inclination to apply it to sustained effort; and, after spending thirty years in trying to interest them in our system of administration, it need not be doubted that the Rulers and chiefs understand, and have their own views upon, all important questions affecting the development of their country and the welfare of the people. A mistake to avoid is the idea that because Malays do not write to newspapers, or often disclose their real thoughts to comparative strangers, they do not feel very strongly indeed on all matters concerning Malay affairs.

One of the best results of federation was the opportunity it gave for the Resident-General to meet all the Residents (and any of the federal heads of departments) in consultation, and so settle in a few days matters which months or years of correspondence would have brought no nearer to finality. A signal instance was the fact that a Land Code for all the States was unanimously adopted at the first conference, and subsequently a Mining Code and many other measures of an equally important and controversial character were discussed, revised, and adopted, every one present showing a real desire to meet the 

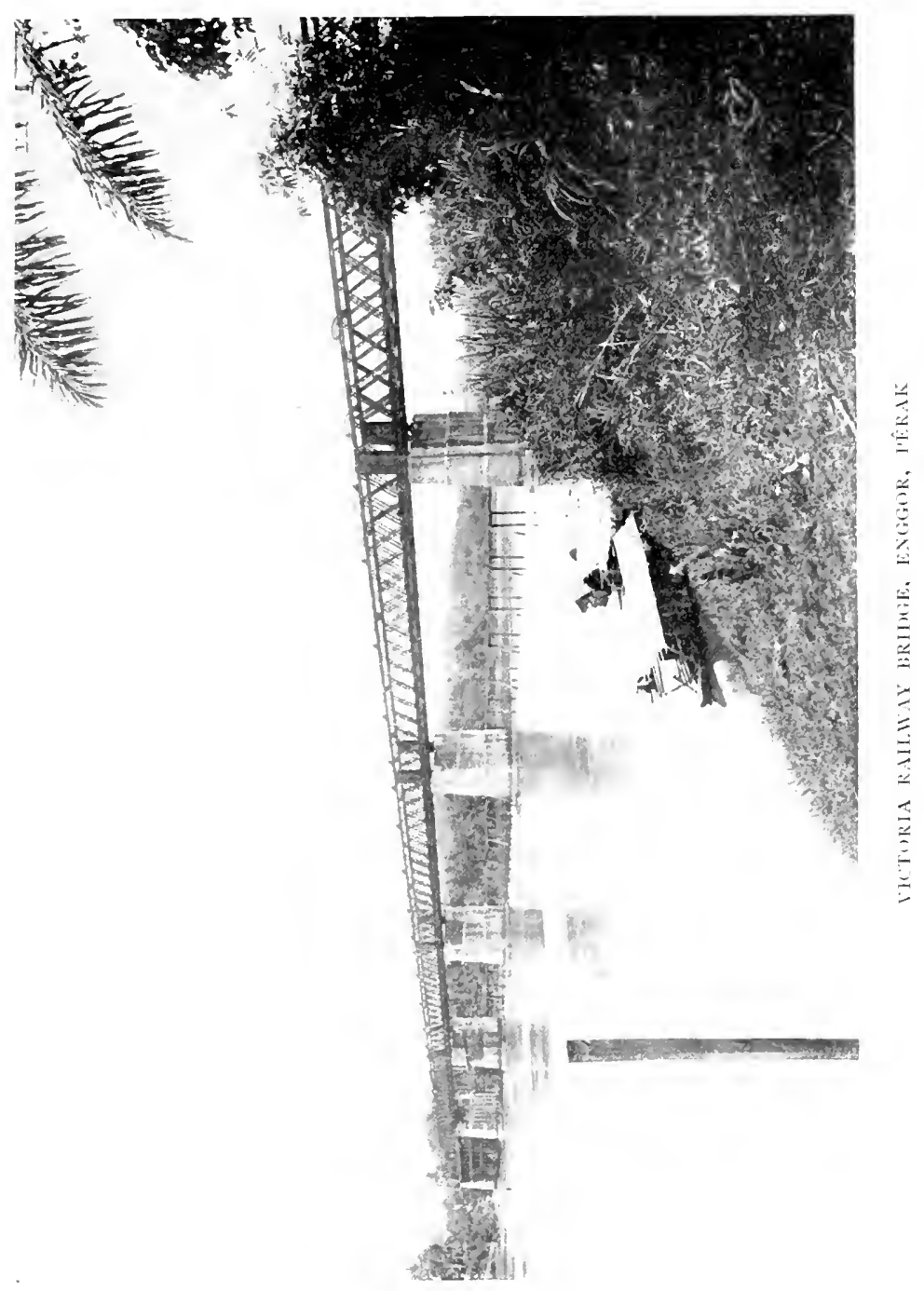

views of his colleagues, to secure unanimity, and to set aside local interests and individual opinions in favour of wider considerations of general advantage. As regards the land question and the terms on which Government land (and that was practically all land) should be alienated, held, and transferred, there had been for years the most serious controversy, the most divergent opinions ever called forth by any administrative question in the Malay States. A very simple set of almost identical regulations had been a sufficient guide for nearly fifteen years. Then something much more elaborate became necessary, and as by that time there were in the States British Residents with very strong views on this and other questions, the result had been that policies were in some cases reversed, in others maintained and accentuated, and there were in different States widely different land laws, causing much very natural dissatisfaction. It was therefore a notable achievement to secure unanimity on a matter of so great importance, and this early promise of enthusiasm for a common cause has been maintained in subsequent conferences of the Residents with the Resident-General.

The rapid and accurate survey of mining and agricultural land had always been a serious difficulty, and will give some dissatisfaction to the public, and cause anxiety to the Government for years to come. Mining land which proves rich in ore is exceedingly valuable, and it is of great importance to owners, to applicants, and to the Government that the land, when once it has been alienated, should be correctly demarcated, surveyed, and entered on the district maps as rapidly as possible. In a country covered by dense forest, with an enormous number of applications being constantly made and a limited staff of surveyors, it will be understood that this is no easy matter. Very early in the history of the Protectorate, a trigonometrical survey of the country was begun in Pêrak, and comparatively large sums have been expended annually 
ever since in carrying on that survey all over Pêrak and extending it to the other States. This was a department which, from its inception, could best have been worked in the interests of all the States, as has been done since federation. The allotment surveys are now made in conjunction with the triangulation, and a uniform policy is pursued in all the States.

Survey work, even the survey of large or small allotments, and the preparation of the plans which accompany every lease issued by the Government, costs a good deal more than the fees paid for it, and, of course, the higher the class of work required the more expensive it is. It may be doubted whether any other administration, so early in its history, has spent so much money and made such efforts to secure high-class work, in all branches of survey, as the Federated Malay States. At least $£ 80,000$ has been spent on the trigonometrical survey for which there is no direct return. An inspection of the land offices throughout the Federation would show the standard of work done in the Malay States, and the efficiency of this department is largely due to the influence and practical experience of Mr. E. W. Birch, C.M.G., now Resident of Pêrak.

The Malay forests are exceedingly valuable, and federation enabled the Resident-General to put their conservancy on a really sound footing. An experienced conservator was obtained from the Forest Department of the Indian Government; he has gradually collected a competent staff, forest reserves have been selected and surveyed, regulations have been introduced, and the whole matter has been systematized. It is some satisfaction to think that these steps were taken before the splendid timber and other valuable jungle products had been destroyed, and it may be mentioned that the existing system is the outcome of the best advice obtainable, for the Malay States secured the services of the head of the Indian Forest Department 
to visit Malaya, inspect the country, and report on the whole question of forest conservancy.

Throughout their later history the Malay States have had no better friend than the Indian Government. If anything I can say will be accepted in acknowledgment of the deep obligation under which the Malay administration lies for a hundred cases of kindly help, rendered by that Great Dependency of the British Crown to the struggling little Malay States, I offer, on their behalf, very grateful thanks, not more for the actual assistance given, than for the splendid courtesy with which the Indian Government always conducts its correspondence, a refusal almost conveying the impression of a favour conferred. The Federation made the only return in its power by contributing generously, and at once, to the last serious Indian famine.

In the year 1900 the Government established an institute for medical research, under the direction of a highly trained and qualified pathologist. This institution is equipped with every modern appliance for carrying out valuable researches; it is, in a measure, affiliated to the London School of Tropical Medicine, has already done valuable work, and may be expected to do much more. The Director has now two qualified surgeons as assistants.

Within the last few years the Federated States have made two new appointments, a Government Geologist and a Director of Agriculture, and much is expected from these officers. In a field so wide the gain to the Government, to miners, and to planters will depend entirely upon whether the knowledge and energies of these specialists are directed towards inquiries of a really practical character, or whether they follow the more inviting paths of purely scientific research, without reference to the special conditions of the country and the special needs of local enterprise.

In order to bring home to the Malays, in the most 
striking manner possible, the reality of federation, arrangements were made to hold a Conference of Malay Rulers, members of State Councils and Chiefs, as nearly as possible on the first anniversary of the coming into operation of the new system. It was proposed that the High Commissioner should open and close the conference, that questions of federal interest should be discussed, and that the opinions of all concerned should be taken on a number of large measures of policy then pending. The Malay Rulers took up the suggestion with enthusiasm, Kuala Kangsar, the seat of the Sultan of Pêrak, was chosen as the meeting place, and, in July, I897, the Conference was duly held and proved a most unqualified success. All the Sultans attended, even the aged Sultan of Sellangor, and not a single notable chief was absent. The arrangements for transporting to Pêrak and there housing, entertaining, and amusing so large a company, for the space of a week, took months of preparation; but all those who shared in the work were rewarded by the success of a scheme which enabled the leading Malays to meet as friends and join with the High Commissioner, the Resident-General, and Residents in real work for the benefit and advancement of Federated Malaya.

After the Sultan of Sĕlangor had invited the High Commissioner to preside, and the Sultan of Pêrak had welcomed those present to Pêrak, the High Commissioner addressed the assembly and declared the Conference open. Before proceeding to any business the Resident-General, on behalf of the Malay rulers, requested the High Commissioner to forward to the Queen-Empress the following telegram, which was at once dispatched.

"We, the Sultans of the Malay States of Sĕlangor, Pêrak, Păhang, and Nĕgri Sambîlan, by the invitation of Your Majesty's High Commissioner, are met together, for the first time in history, to discuss the affairs of our States confederated under Your Majesty's gracious protection. We 


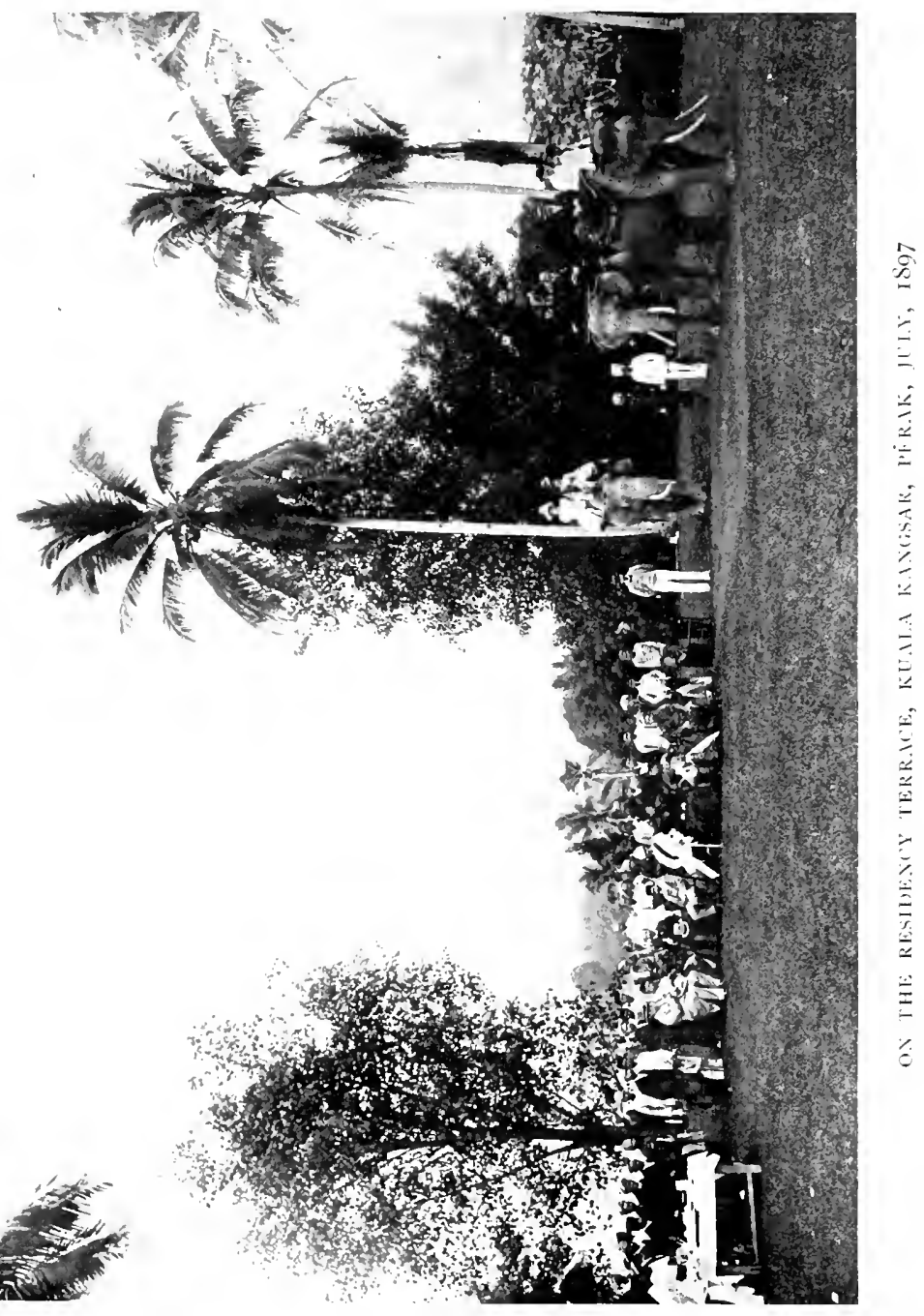



desire to offer to Your Majesty our respectful and cordial congratulations on a reign of unexampled length and unequalled progress, and we pray for Your Majesty's long life and the continuance of that protection which has already brought such prosperity to Malaya."

In the following days a great deal of very useful work was done, all the Sultans and many of the chiefs frequently speaking on the various questions under discussion, and taking a keen interest in all the proceedings.

The following is from the Resident-General's Official Report of the proceedings :-

"From every point of view the meeting has been an unqualified success, and it is difficult to estimate now the present and prospective value of this unprecedented gathering of Malay Sultans, Rajas, and chiefs. Never in the history of Malaya has any such assemblage been even imagined. I doubt whether anybody has ever heard of one Ruler of a State making a ceremonial visit to another; but to have been able to collect together, in one place, the Sultans of Pêrak, Sĕlângor, Păhang, and the Nĕgri Sambîlan is a feat that might well have been regarded as impossible. People who do not understand the Malay cannot appreciate the difficulties of such a task; and I confess that I myself never believed that we should be able to accomplish it. It was hardly to be expected that a man of the great age of the Sultan of Sellângor could be induced to make, for him, so long and difficult a journey, and to those who know the pride, the prejudices, and the sensitiveness of Malay Rajas, it was very unlikely that the Sultan of Păhang would join an assemblage where he could not himself dictate the exact part which he would play in it. It is not so many years since the Governor of the Straits Settlements found the utmost difficulty in getting speech with Malay Rajas in the States which are now federated; Sir Frederick Weld, even 
though accompanied by the present Sultan of Pêrak, by Sir Hugh Low, and the present Residents of Sĕlângor and Păhang, all officers accustomed to deal with Malays, had to wait several hours, on the bank of the Păhang River, before any one could persuade the Sultan of Păhang to leave a game of chance in which he was engaged with a Chinese, in order to grant an interview to His Excellency. It is difficult to imagine a greater difference than between then and now, and, though the Sultan of Pêrak has been far more nearly associated with British officers than any other of the Sultans, he has always been extremely jealous of his rights as a Ruler. I was, therefore, surprised to hear the frank way in which, at the Council, he spoke of British protection, which he did not hesitate to describe as control.

"The deliberations of the Council were both interesting and useful, and there is no doubt that, in some respects, we could not have arrived at the same ends by any other means than the meeting of the Rajas of the Federated States and their responsible advisers. All the proceedings of the Council were conducted in the Malay language, and I am convinced that, if ever it were necessary to introduce interpretation, no such successful meetings as those just concluded could ever be held. The Sultans and all their chiefs spoke on all the subjects which interested them, without either hesitation or difficulty, and on matters concerning the Mahammadan religion, Malay customs, and questions which specially touch the well-being of Malays, it would be impossible to find elsewhere such knowledge and experience as is possessed by those present at the recent meetings. Nothing can be decided at the Council, which is only one of advice, for no Raja has any voice in the affairs of any State but his own. This was carefully explained and is thoroughly understood. But it is of great value to get together the best native opinions and to hear those qualified to do so thoroughly discuss, from 
varying points of view, questions which are similar in all the Federated States. On several important subjects the members of the Council expressed unanimous views, and it now only remains to take action in the various State Councils to secure identical measures embodying the opinions expressed."

This I 897 Conference was such a pronounced success that by the desire of the Malays, it was decided to repeat it from time to time as found desirable and convenient, and on each occasion to assemble in a different State, so that each Sultan in turn might have the pleasure of welcoming the neighbouring rulers, of showing them his country, and the hope was expressed that the friendships then so happily made might be renewed.

A second and equally successful Conference was held at Kuala Lumpor, in Sělangor, in July, I903. Again the deliberations of the assembly, after much interesting discussion, resulted in a number of important decisions chiefly connected with matters in which the Malay population was specially concerned. This Conference was rendered notable by the fact that the Rulers of all the western States were conveyed to Kuala Lumpor by train, only the Sultan of Păhang and his chiefs having to travel by sea, and also by reason of a remarkable speech delivered by the Sultan of Pêrak at the close of the proceedings, when $\mathrm{His}$ Highness gave a graphic account of British intervention in the Malay States, and the benefits which had been conferred on the country and people by the adoption of British methods of administration. The Sultan spoke freely of his own and his people's early suspicions and distrust of the white man and how they had gradually changed their minds. His Highness laid special stress on the fact that he and his people had given their confidence and lasting friendship to those Residents who came with the evident wish to secure them.

If in earlier pages I have been able to give the reader 
an intelligible idea of this waste of jungles and swamps, of mountains and rivers, sparsely inhabited by a far from industrious or happy people, preying on each other and on the heaven-sent Chinese toiler in an atmosphere of eternal heat, tempered by frequent deluges of tropical rain; if I have been able to show him something of the extraordinary change which has passed over the country and the people, lighting the dark places, bringing freedom and comfort and happiness to the greatly oppressed, and wealth to the greatly industrious; if now the reader sees a country covered with prosperous towns and villages, with roads and railways, with an enormously increased population, with every sign of advancement and prosperity, and if he also understands, in a measure at least, how this change has been brought about, I will cease to trouble him with further details of this unique experiment in administration, and will only mention a very few of the most remarkable results of British intervention in Malay affairs.

In an old Parliamentary paper I have found the following passages which I wrote as Resident of Pêrak, in March, I 895, that is immediately before the federation of the States. I quote them now because they emphasize the true secret of administrative success in the Malay States. I draw a distinction between what, for want of a better word, may be called the political problem, and the administrative problem presented to the British Residents. The first was solved by the Residents identifying themselves with the Malays, by speaking their language, sympathizing with their customs, shewing consideration for their prejudices, consulting them about everything, making friends with them and getting at their hearts. The other was done by developing the country before the means of paying for it were actually available. To do this intelligently, it was necessary to know the States as far as they could then be known, and 


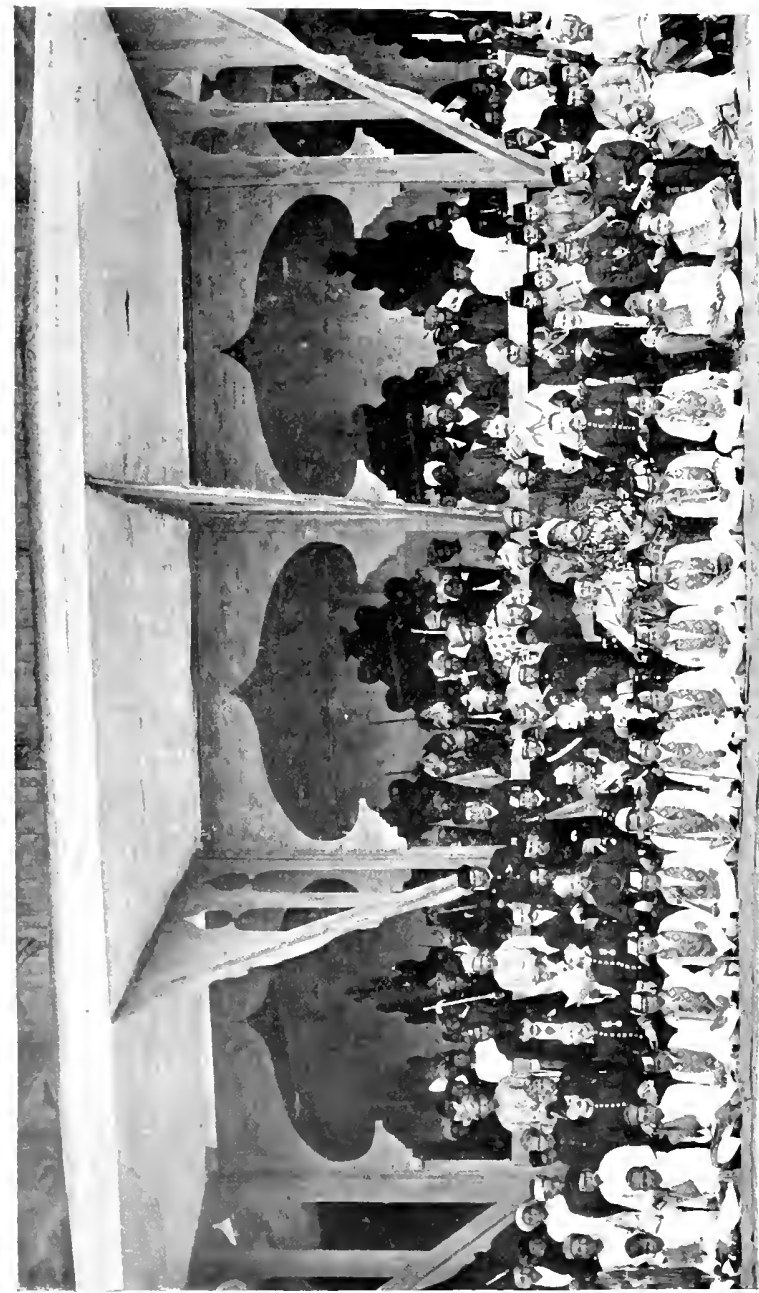

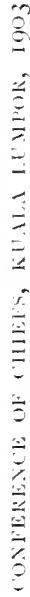



have the courage to spend money with the confidence that it would all come back again, directly or indirectly. How far that policy was justified is shewn by the passages here quoted :-

"Since I 890 the revenue has increased 40 per cent. and by the end of this year the increase will probably be 75 per cent. The production of tin has increased by over 50 per cent.; the export of padi (unhusked rice) is nearly twenty times what it was in 1890 , and that of sugar is more than double. The value of the Customs revenue has doubled, and of the land more than trebled. The railway receipts last year were three times, and this year will be nearly eight times, as large as in 1890 . The postal business has increased fourfold, and that of the telegraph offices has more than doubled, while the trade of the State has increased from a value of $\$ 17,000,000$ to nearly $\$ 27,000,000$. And this is not quite all. With the progress and prosperity of the State the well-being of its people has kept pace. I have already said that the position of our Chinese labourers-the bone and sinews of the body politic-has vastly improved. There are very few Europeans who are able to compare the condition of the Malays now with what it was when Sir Andrew Clarke signed the Treaty of Pangkor in January, I874. The change for them has been certainly remarkable. I have no desire to enlarge on the greatness of their gain, but it is evident enough to those few who knew the Peninsula then and can see it now; moreover, the Malays themselves are conscious of their altered condition and grateful for it. It would hardly be an exaggeration to say that the position of all classes of Malay society and all individuals has been bettered. The power of the governing classes is, in one sense, far less than it was when British assistance was invoked, but their influence is certainly wider. As a class they are better housed, better clothed, wealthier, and in every sense more comfortable. 
The same is the case with the lower classes; they have gained exactly in proportion to that power which their chiefs have lost. Their lands, which were valueless and in many cases abandoned, are now cultivated, fenced, cared for, and acquiring a value which in some cases is considerable and in all appreciable. The wealthiest Malays in the Peninsula are the Pêrak Malays. It is for them that the richest silks of Trĕnggânu and Bâtu Bâra are woven, it is they who vie with each other in the building of expensive houses and the possession of horses and carriages, while many of them own residences in the Sacred City of Mecca. The richest man in Malaya is a member of the Pêrak State Council and made all his fortune in this State.

"The lesson to be learned from these facts and figures is, I think, a very plain one. It is, that in the administration of a Malay State, revenue and prosperity follow the liberal but prudently-directed expenditure of public funds, especially when they are invested in high-class roads, in railways, telegraphs, waterworks, and everything likely to encourage trade and private enterprise; and in this the Malay State is probably not peculiar. The Government cannot do the mining and the agriculture, but it can make it profitable for others to embark in such speculations by giving them every reasonable facility, and that we have tried to do. If we had kept our funds in Indian securities, or if we had simply devoted our energies to building up large balances for the pleasure of looking at and talking of them, the progress of the State would have been a good deal less marked, and it is impossible to say whether, hereafter, our funds might not have been diverted to some other purpose, and Kinta, years hence, be still no nearer the immense boon of a railway to the port of Teluk Anson than Singapore is to-day to that railway across the Island which was so strongly advocated nearly twentyfive years ago.

"I confess that I am inclined to carry this principle of 
the value of liberal expenditure on well-considered objects into almost every department of the public service of this State. The money that is spent is only invested, and comes back in increased revenue, while the State gains in palpable benefits like roads, railways, and other works, or in the increased efficiency of the administration. Both add to the revenue. A new road, or an additional officer, equally proves this truth, if the road is in the right direction and the officer does his work. That, at least, is the experience of the past, and it may be peculiar to the opening of new countries, especially when they are so rich in resources as the Malay States.

"I am not personally anxious to see the mineral wealth of Pêrak exported, in ever-increasing quantities, when the price of tin has dropped in two years from $£ 90$ to $£ 63$ a ton and is still falling; and yet we are to a large extent responsible. The enormously improved facilities of transport that we have provided enable the miners to work great mineral fields so much more economically that they can now, even at the present price of tin, afford to turn over ground that ten or fifteen years ago would have been neglected as unpayable, and the enormous quantities of the metal exported from the Malay States have no doubt brought down the price. Pêrak alone has contributed $£ \mathrm{I} 6,500,000$ worth in the last twenty years. It is true that our capital (in the shape of tin) is leaving the country, but what has gone is probably only a fraction of what remains, and beyond imposing a high export duty, there is no special reason to try to control the production. The duty that is paid to us is exceptionally high (if the price of the metal continues to fall, it may be necessary to reduce it), and as it is the revenue derived from this source that has enabled us to construct our roads and railways, we are building up a capital of another and better kind. Our lines of communication do something more than enable the miner to get his rice cheaply and 
transport his produce to a market at particularly low rates; the railways, besides their other advantages, yield a large and direct revenue; this year in Pêrak it will amount to nearly $\$ 700,000$, of which probably more than half will be profit, giving a return of about Io per cent on capital invested; the roads feed the railways, and themselves indirectly contribute largely to the revenue. But the main point is that both roads and railways will open up the agricultural capabilities of the country and give us the best thing we can hope for: a settled agricultural population and a body of Europeans who will bring their brains, their energy, and their money to convert our jungles into extensive estates of permanent cultivation, a form of enterprise such as no Asiatic has hitherto had the ability, experience, or determination to attempt.

"If the falling price of silver is helping the miners of the Malay Peninsula to crush all rivalry in Cornwall or Australia, the same cause will give a manifest advantage to the planter who sells his coffee, tobacco, or spices in a market where payment is made in gold. The conditions of soil, of climate, and rainfall that he requires are here; the transport facilities are good and improving yearly; labour is cheap and may be made plentiful; and all that remains is that the Government should be liberal in the terms on which it alienates the land. It is the opportunity of the planter, and it is also the opportunity of the Government; it would be a serious blunder if the fact were not grasped that the interests of both are identical.

"Failures cannot benefit the Government, and at this moment, when European planting in the Malay Peninsula is still in its infancy, the man who brings us his capital, invests it in agriculture and loses it, can only serve as a scarecrow to frighten away intending planters.

"Mining is and must ever be surrounded by risks ; it is an unfortunate fact that many Europeans have invested considerable sums in mining ventures in the Malay States 
and have lost them; and yet it is not and has not been urged that the Government has placed difficulties in the way of acquiring mining land. When the British Government undertook to advise the Malay chiefs in the government of their countries, there were no alluvial tin mines in any British territory nearer than Australia, and no objection has therefore been raised to the regulations framed in the Malay States for the conduct of an industry that has now no rival in the world in the magnitude of its operations. We give to the miner what is often fine land covered with magnificent forest, and when he has destroyed the timber, he turns the soil upside down and after a few years abandons it, leaving huge stretches of country a sightless waste of water-holes.

"Whilst the operations last the Government secures a large revenue, and, as I have already explained, that revenue has been very usefully employed.

"The case of the planter is the exact reverse. He converts the jungle into produce-yielding fields, he settles on the soil: it is to his interest to foster to the utmost a property which will only give him a fair return arter the investment of capital and years of toil. His object is to keep the land in cultivation, and when one product fails (as coffee failed in Ceylon) he immediately turns his energies to the introduction of another.

"Here also there is a permanent revenue to be gained from the export duty on produce, and it wants no great effort of imagination to see a day when the duty on agricultural exports may exceed that on minerals. The returns in the latter case are much more rapid; but to make it easy to mine successfully and difficult to plant with profit may be good shopkeeping, but seems indifferent administration.

"I feel very strongly that the Government cannot pursue a wiser policy than the encouragement of the planter. I have been told that the terms on which land 
has been granted to planters in the Malay States under the regulations which I drafted are too liberal, that they are thriftless, and I have failed to safeguard the future interests of the Government and retain the power to share in the rising value of alienated lands. The revenue returns of the last five years, given in paragraph 63 ante, are some indication of the result of the policy hitherto pursued in Pêrak, a policy which was endorsed by the great experience and sound judgment of Sir Hugh Low. Up to the present time, planting in Pêrak has been confined, with very few exceptions, to small native cultivators; but while the Government retains the power to determine the amount of the export duties, and while there remain millions of acres of land available for planting, and the total area granted is only I 57,209 acres, I do not think the interests of the State can be said to have been greatly neglected in the past or seriously endangered for the future.

"The Native States have not, so far, suffered from want of initiative. Of what has been done (and that can best be seen on the spot) little is due to outside influence, but local efforts have not always been unhampered. Sometimes, no doubt, we may have been inclined to think we know our own needs best, and the excuse for that impression is to be found in the result of the last twenty years' administration, and the fact that those responsible for the initiative are not working for their personal profit but in the interests of the Malay States, interests which may be lost sight of when viewed from a distance."

That was written in 1895 , and I am quite content to stand by every word of it now.

The latest details available carry us to the close of the year 1905, and though, in some respects, it might be more satisfactory to give the returns for each State separately, a true conception of the result would be blurred by the mass of figures. 


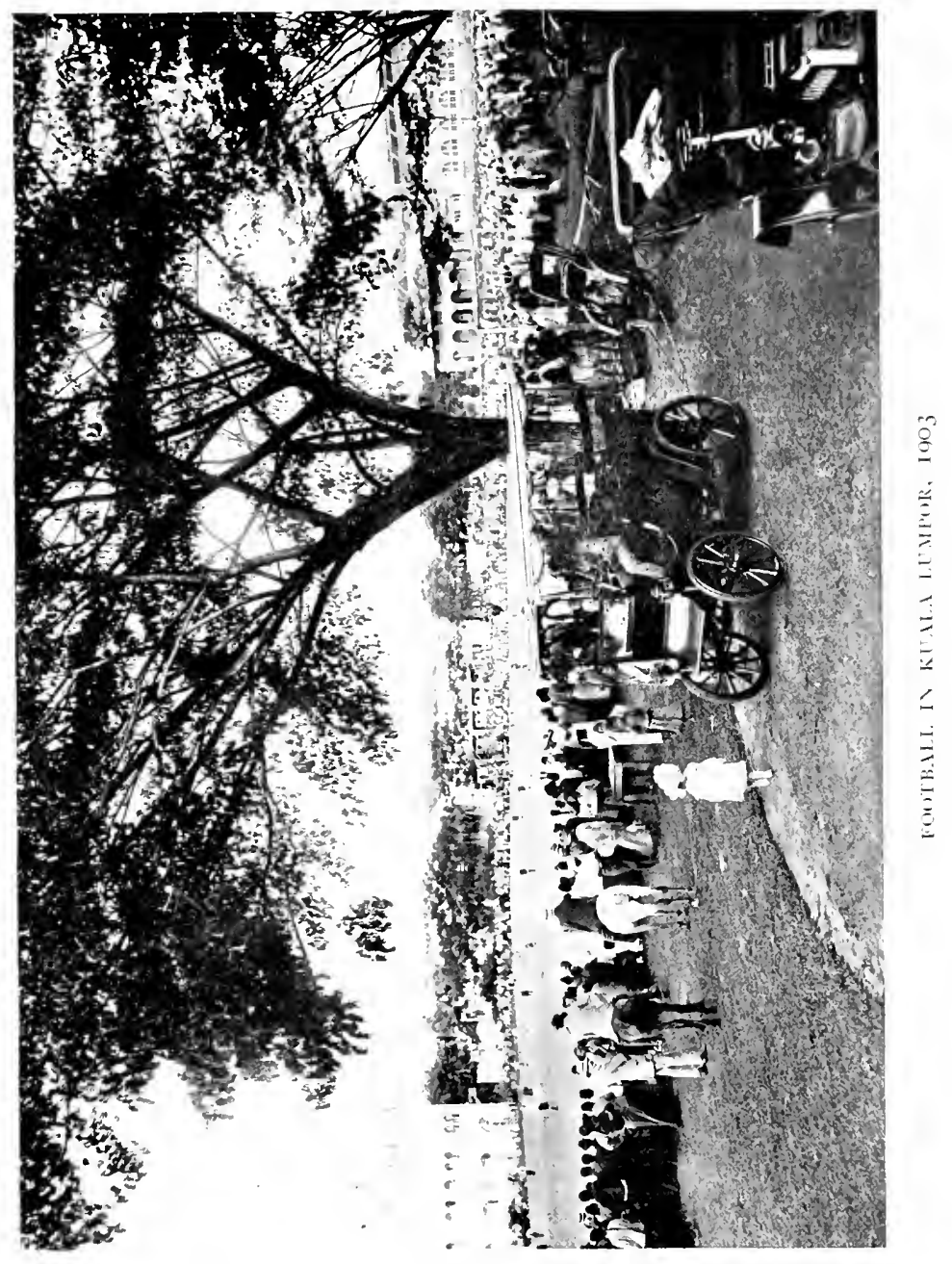



The following table gives a general view of the progress of the States under British advice and control at intervals of five years, from the first appointment of Residents to 31 December, 1905. It shows the revenue and expenditure, the trade (that is, the value of imports and exports), the duty paid on tin, the land revenue, the forest revenue (which prior to I90I appeared as land revenue), the postal and telegraph receipts, and the railway receipts.

The population of Pêrak was returned, in I 879, as 81,084, and in 1889 had risen to 194,801 . The first year which records the population of the four States is $189 \mathrm{I}$, when the total was returned as 424,2 I 8 . In I90I the numbers had risen to 678,595 , and the estimate for 1905 is 860,000 .

All these figures are so significant that it seems a small thing to mention that a country which, in I874, had no post office and had never seen a postage stamp, in $1904^{1}$ dealt with about $10,000,000$ covers, issued money orders to the value of over $\$ 1,250,000$, had $\$ 275,000$ in the Post Office Savings Banks, and maintained over 2000 miles of telegraph wires. In the same year the prisons received I0,000 prisoners, the hospitals treated 46,000 in-patients and 130,000 out-patients at a cost of over $£ 50,000$ a year, and the schools were attended by over I3,000 scholars. In 1875 the States did not possess a mile of first class road, but in 1904 there were over 2500 miles, the greater part of which will compare favourably with the roads in any country, while 340 miles of railway, built at a cost of $\$ 32,000,000$, were open for traffic, and, when the present extensions are completed, the Federation will have constructed and equipped close on 500 miles of railways, out of current revenue, without borrowing a farthing. Indeed, the Government balances at the end of 1905 amounted to

1 It is possible to give the following figures for 1905. Postal revenue, $\$ 296,323$; money orders issued, $\$ 1,79 S$, 147 ; in-patients in hospitals, 55,467 ; out-patients, 120,304; schools attended by 15,241; cost of education, $\$ 322,512$; railways open, 396 miles, at a cost of $\$ 37,261,922$. 


\begin{tabular}{|c|c|c|c|c|c|c|c|c|}
\hline 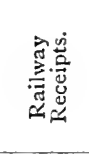 & 1 & 1 & $\begin{array}{l}n \\
\infty \\
\infty \\
\infty\end{array}$ & $\begin{array}{l}\text { N } \\
\text { O } \\
0 \\
0 \\
\text { O }\end{array}$ & 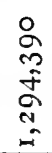 & 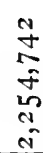 & वे & \multirow{10}{*}{ 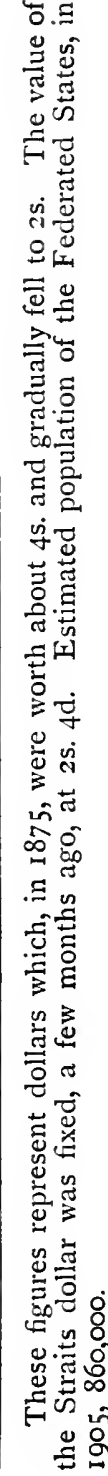 } \\
\hline 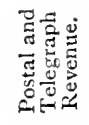 & $\stackrel{+}{\circ}$ & $\stackrel{\ddot{n}}{\sim}$ & 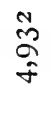 & $\frac{1}{5}$ & $\begin{array}{l}2 \\
2 \\
0 \\
0 \\
0\end{array}$ & $\begin{array}{l}\text { in } \\
\text { in } \\
\text { a } \\
-1\end{array}$ & iv & \\
\hline 讪苛 & 1 & 1 & $\mid$ & 1 & 1 & 1 & Nิ & \\
\hline 苞 & రి & $\begin{array}{l}+ \\
+ \\
\infty \\
\infty\end{array}$ & $\begin{array}{l}\text { in } \\
\text { ज }\end{array}$ & 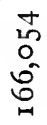 & $\begin{array}{l}a \\
m \\
N \\
\infty \\
0 \\
0 \\
y\end{array}$ & 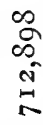 & $\begin{array}{c}r \\
0 \\
1 \\
\infty \\
\infty\end{array}$ & \\
\hline 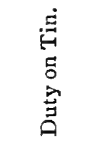 & 1 & 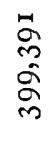 & \begin{tabular}{c}
\multirow{2}{N}{} \\
\multirow{N}{N}{} \\
$\infty$
\end{tabular} & 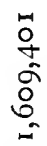 & 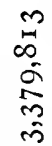 & 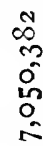 & ô & \\
\hline 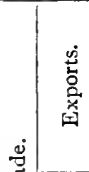 & 1 & $\begin{array}{l}\text { a } \\
\text { in } \\
2 \\
0 \\
0 \\
0 \\
01\end{array}$ & 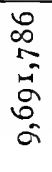 & 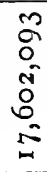 & $\begin{array}{l}\text { in } \\
\text { o } \\
\text { N } \\
\text { N } \\
0 \\
\text { nf }\end{array}$ & $\begin{array}{l}\text { in } \\
0 \\
0 \\
6 \\
0 \\
0 \\
0\end{array}$ & $\begin{array}{l}\text { บั } \\
1 \\
0 \\
0\end{array}$ & \\
\hline 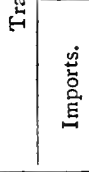 & 1 & 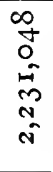 & 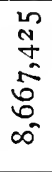 & \begin{tabular}{l} 
Oे \\
$\infty$ \\
nీ \\
\multirow{+}{+}{} \\
in
\end{tabular} & $\begin{array}{l}\text { N } \\
\text { N } \\
\text { No } \\
\text { ON } \\
\text { N } \\
\text { N }\end{array}$ & 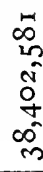 & 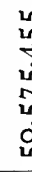 & \\
\hline 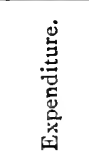 & $\begin{array}{l}N \\
\infty \\
\infty \\
0 \\
0 \\
+\end{array}$ & 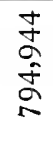 & 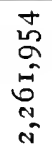 & 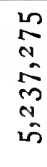 & $\begin{array}{l}\text { in } \\
\text { in } \\
\text { in } \\
\infty \\
2 \\
2\end{array}$ & $\begin{array}{l}0 \\
\text { O } \\
\infty \\
N \\
N \\
N \\
N \\
N\end{array}$ & 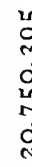 & \\
\hline 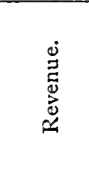 & $\begin{array}{l}\text { すे } \\
\text { ja } \\
\text { oे }\end{array}$ & 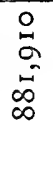 & $\begin{array}{l}9 \\
0 \\
0 \\
0 \\
0 \\
0 \\
\text { on } \\
\text { an }\end{array}$ & $\begin{array}{l}\text { ᄂn } \\
0 \\
0 \\
0 \\
0 \\
\text { f }\end{array}$ & 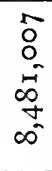 & $\begin{array}{l}1 \\
0 \\
\infty \\
\delta \\
0 \\
0 \\
\text { in } \\
\text { n }\end{array}$ & g̊ & \\
\hline 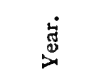 & $\stackrel{\infty}{\infty}$ & $\begin{array}{l}0 \\
\infty \\
\infty \\
1\end{array}$ & $\stackrel{\infty}{\infty}$ & $\stackrel{\circ}{\circ}$ & in & 음 & $\stackrel{2}{\circ}$ & \\
\hline
\end{tabular}


no less than $\$ 22,000,000$. It may be questioned whether it is possible to find, in the history of British administration over-seas, a parallel to this record.

How far the present prosperity of the Federated Malay States is due (I) to Chinese, (2) to Europeans, and (3) to British officers in the service of the Malay Government, is an interesting question which admits of an unhesitating reply. Chinese enterprise and Chinese industry, as has been explained, supplied the funds with which the country was developed. But without the British officers to secure order and justice, the Chinese would never have entered the country in tens of thousands; without British control of the revenues, there never would have been any money to spend on the construction of roads and railways and all the other works of development; and without the exercise of foresight and intelligent direction, the funds available would have been much smaller and might have been spent in vain. European planters and miners only came into the States when the result of Chinese enterprise had already proved the rich resources of the land, but to these Europeans belongs-especially in three notable instances - the credit of valuable assistance in the advancement of the Protected States. They introduced hydraulic sluicing and other scientific methods in dealing with the alluvial tin deposits. They extended the use of machinery, and they were the first seriously to attempt underground mining, whether in alluvial deposits or in the rock, and whether in mining for tin or gold. Secondly, it was Europeans who introduced scientific planting on a large scale. They hold the field in this respect; they are rapidly extending the cultivation of valuable and permanent products, and their work may in time prove as useful and contribute as largely to the revenue as the mining industry. Thirdly, it was the European planters, chiefly men who had migrated from Ceylon, who introduced, or influenced the introduction of, a very large pro- 
portion of those Indian immigrants on whom they and the spending departments of the Government depend so largely for cheap labour.

The Malays are rice growers and planters of cocoanuts and other fruit trees, and it is very satisfactory to know that in the last thirty years these cultivations have been enormously extended. The Chinese are miners, marketgardeners, artizans, shopkeepers, contractors, financiers, and revenue farm holders. In a few cases they are now planters on a large scale. Natives of India are labourers of all kinds, and when they have saved a little money they become cultivators, owners of cattle, cart drivers, and follow other useful avocations. It is, however, to the English servants of the Government that the present prosperity of the Malay States is mainly due. In the earliest days they strove, in a manner probably unknown elsewhere, to induce natives of all nationalities to settle in the States. They spared no pains to persuade Malays, Chinese, and Indians to come into the country to take up land, to build houses, to start industries, and then to bring their relatives and friends to do the same. The Government made advances to these settlers, and Government officers nursed them in every possible way, made things pleasant for them, knew them all, and took an interest in them, praised their cottages and their gardens, gave them the energy they lacked, and often endued them with a spirit of rivalry which led to the building of villages, the planting of orchards, the cultivation of profitable produce, and later taught them a pride in their surroundings which amounted to the gift of a new sense. In the strenuous labour of these early days, when every one lived in extreme discomfort-a discomfort almost impossible to realize now-the Residents and the District Magistrates took the leading part, and whilst it is impossible to mention the names of all those who gave of their best to secure success, I cannot omit these five-Martin Lister, 
Patrick Murray, Henry Syers, Noel Denison, and Arthur Butler-all of whom died while still holding offices of great trust and responsibility in the service of the Malay States. It is a noteworthy fact that all of them enjoyed in a high degree the confidence of the Malays, to whose interests they had devoted themselves from their first arrival in the Peninsula.

Until I903 all Government servants had been paid in dollars, the value of which constantly fluctuated, and for thirty years the general tendency had been downward, so that a coin which in 1870 had been worth $4 \mathrm{~s}$. 6 d., in 1903 was worth less than $2 \mathrm{~s}$. This depreciation of the purchasing price of the currency had caused much dissatisfaction and hardship, and all sorts of devices, not very clever devices, had been resorted to in order to make up for the loss. From I January, 1903, the Colonial Office was at last persuaded to agree to the placing of all salaries of European and other servants drawing over $£ \mathrm{I} O 0$ a year on a sterling basis, and the opportunity was taken to give a more generous scale of remuneration than that hitherto paid. Government officers in the Malay States have always enjoyed the great privilege of free quarters, and though their salaries are still very much smaller than those paid for similar duties in the Indian Presidencies, they compare favourably with the rates which obtain in any Crown Colony. Even so, the cost of the establishment (that is the charge for salaries and allowances) is less than one-fifth of the revenue, whereas in other placesthe neighbouring colony, for instance-it amounts to about one-third. That the services performed have been, and are, efficient has never been questioned, but the moderate cost of the Malay administration has passed unnoticed.

Now that order has been firmly established for so many years, that the country enjoys in such a large degree the benefits of the most modern institutions, and that the temper of the Malay population has ceased to cause anxiety, 
one is apt to forget the difficulties of persuading an extraordinarily isolated, peculiar, and conservative people to accept an entirely new scheme of things. It was, however, necessary, under the special circumstances of the case, to so persuade them, and to educate them to take their part in the reconstruction of the administration. In that work the Malay village head-men rendered the most valuable assistance. They were chosen partly on account of hereditary claims, partly by popular election, and the fact that they were induced to take the side of the Government, and use their influence in the interests of peace and order, was of such importance that without their sympathy and assistance the task of the Resident might at any moment have been rendered almost impossible.

Quite recently Lord Curzon said: "If I were asked to sum up what were the lessons which Eastern government had given me, I should say they were these: In the first place, remember always that you are not in India or in any foreign dependency for the benefit of what in diplomacy is called your own nationals. You are there for the benefit of the people of the country." I quote that statement because of the high authority of the speaker, because it cannot be repeated too often, and because, in all the East, I believe there is no country where it has been so faithfully observed by British officers as in the Federated Malay States. Two or three years ago a distinguished American, commissioned by his Government to visit the Malay States and see how far our methods there might be adopted in the Philippines, said, "You have done so much for the Malays that there is nothing left to do, unless you divide the surplus revenue amongst the people."

There are people who have no patience with the Malays, who say they are lazy and useless and have already received far too much consideration. That is a view which, I trust, will never find sympathy with those who have 


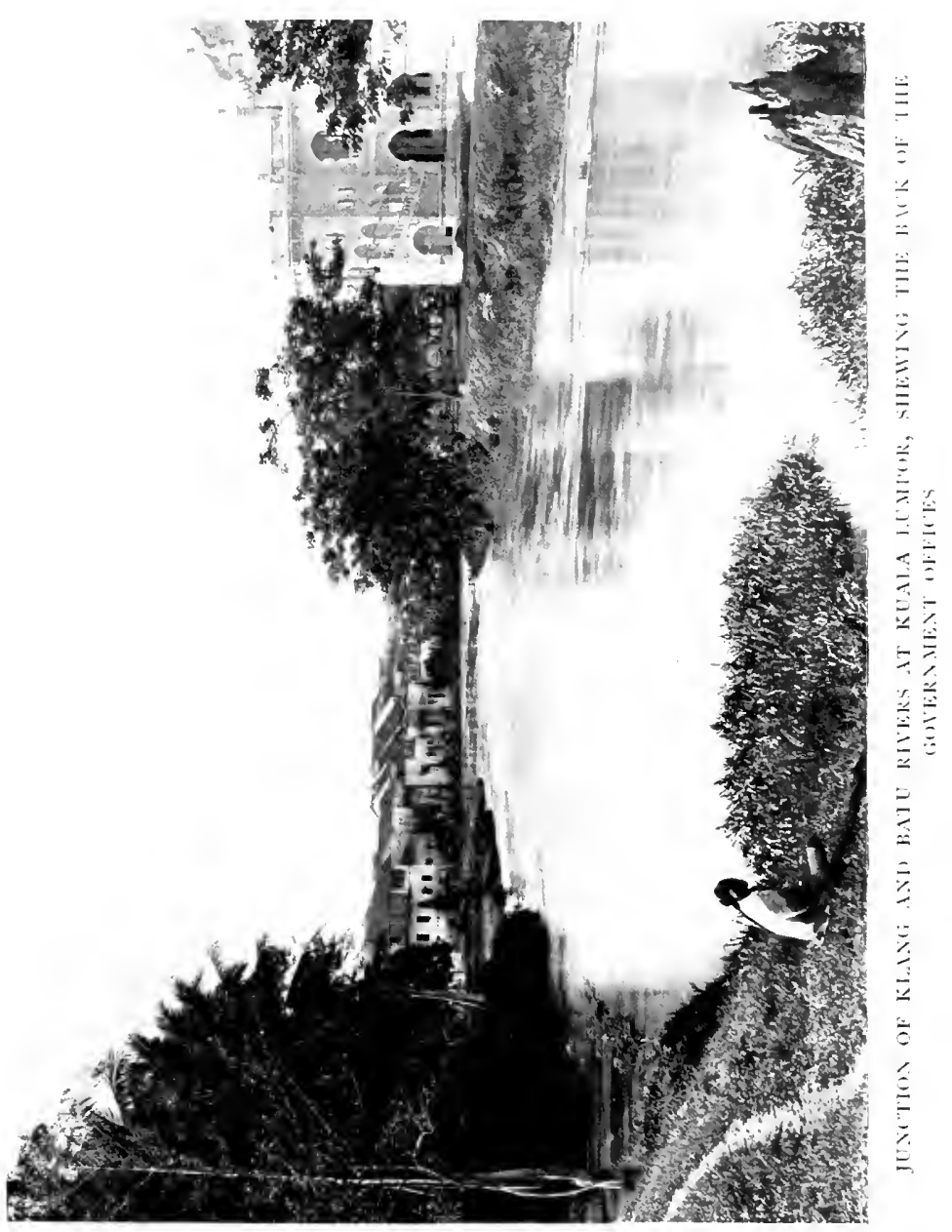



authority to control the destiny of people who have passed through phases of dislike and suspicion to an absolute belief in the genuineness of our profession that we had undertaken our task in their interests. As for being lazy and useless, there are practically no Malay paupers, and in that enervating climate the easy life attracts. Malays do enough work to satisfy their needs, and nature is so bountiful that that is very little. They do not strive for riches, but they are probably as happy and contented as other people who regard life differently, and it is questionable whether we should deserve their thanks if we could teach them the tireless energy, the self-denying frugality of the Chinese. And for what? Often in order that their children, or the adopted children, may squander, in a few years, what their fathers have collected by a lifetime of toil. You cannot make people virtuous by Act of Parliament, and you cannot graft the Chinese nature on to the Malay body. The Malays are "the people of the country"; we went to the Malay States for their benefit, and we have somehow managed to give them an independence, a happiness and a prosperity which they never knew before; and while it is not the Malays alone who have thus benefited, but all classes and nationalities, the credit is due to a few British officers who strove ceaselessly for that object which Lord Curzon puts first amongst the lessons taught him by Eastern administration. 


\section{CHAPTER XIII}

CONCERNING THE MALAY STATES WHICH ARE NOT INCLUDED IN THE

FEDERATION

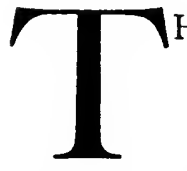

THE Federated Malay States cover an area of 25,000 square miles, and, with Province Wellesley and Malacca, they include the whole eastern shore of the Straits of Malacca, except the most southern section which, for nearly a hundred miles, lies within the territory of Johore. Johore is the only State in the Peninsula which has one shore in the Straits of Malacca and the other in the China Sea. The territory is of considerable extent, but the population is comparatively small, and the country is but little developed. There are no published statistics of area, population, trade, revenue, expenditure, or on any other subject which would be useful to the inquirer. As already stated, Johore has treaty relations with the British Government, which has the right to appoint an agent to reside in the territory. The administration centres in the Sultan, who employs a very few European officers and a number of Malays to assist him in the management of affairs. The capital, Johore Bhâru, is a neat little town on the Johore Strait (Silat Tembrau is the Malay name), exactly opposite the terminus of the Singapore Railway. Just outside the town is the Sultan's Astâna, or palace, and, apart from an imposing mosque, the public buildings consist of a somewhat out-of-the-way block of offices, 
a prison, a hospital, a court, police-station, barracks, a treasury, post office, and a small school-house. There are some miles of fairly good road to a place called Kota Tinggi, and some which have at present no definite objective. On the Muar River, near to Malacca, there is another small town called Bandar Maharâni, and in its neighbourhood a good deal of useful planting has been done. There is tin in Johore, but no great effort has yet been made to prove its extent and value; probably because the Government has not exerted itself to give the necessary transport and other facilities. In great part the country is still covered by jungle, but Singapore Chinese have, during the last sixty years or so, spread gambir and pepper plantations over a wide area, always choosing land as near as possible to the shores of the Johore Strait, or on the bank of a navigable river. In the absence of roads this was, of course, a necessity. The Chinese population engaged in these enterprises have supplied almost the whole revenue of the State, either directly or indirectly, and the Sultan has for a good many years received about $£ \mathrm{r} 20,000$ annually from the revenue farms of opium, spirits, gambling, and pawnbroking, from the export duties on gambir, pepper, and other produce, and from minor sources of taxation. Had even half, or a quarter, of the revenue been regularly spent upon the wise development of the country by means of a carefully devised system of roads, and had the administration been conducted on sounder principles by capable and energetic officers, Johore would have been to-day in a very different position. Gambir and pepper plantations exhaust the soil in a special degree, and gambir is one of the most wasteful cultivations imaginable. Enormous areas of virgin forest, containing valuable timber and other products, are felled and burnt, the gambir shrub is planted, and though the first crop of leaves may be picked after fourteen months, and further cropping made every two months, the 
shrub does not last many years, while it exhausts the soil and renders it useless for any other purpose. It is then abandoned and the process is repeated, destroying thousands of acres of land and timber, and leaving the State with nothing but a waste of impoverished soil. If any circumstances would justify the encouragement of such an industry on a large scale, it could only be to induce capitalists to introduce labourers into an uninhabited country, in the hope that they would remain as permanent settlers, and to spend on works of development all the revenue derived from this source. Pepper also exhausts the soil, but the vines will last for many years, and a pepper garden covers a comparatively small acreage. Unfortunately, the Chinese seldom start a pepper garden (which only gives an appreciable return after three years) without attaching to it a huge gambir plantation, and the leaves of the shrub, when they have been boiled and the gambir extracted, are used to fertilize the pepper vines.

Now that the Federated Malay States are constructing a railway right through the heart of Johore, and European planters are turning their attention to that State as a suitable field for the cultivation of rubber and other permanent products, Johore is offered a great opportunity of getting into line with its neighbours. Unless, however, efforts are made to develop the country, and especially to feed the railway by good roads, the opportunity will be missed, and the railway will fail to do for Johore what it has done with such splendid success for the Federated States, every one of which was, thirty years ago, far more backward than Johore at the same date.

In consenting to the construction of the railway, the present Sultan has done more for Johore than any of his predecessors, and if he now encourages all genuine attempts to develop the mineral and agricultural resources of his country, especially if he determines to make personal 
sacrifices in order that his State may have the benefit of well-considered public works, he will reap a rich reward in personal credit, and a substantial increase to his revenues. But the present sacrifice is necessary ; for while he is supposed to receive $£ 30,000$ a year for his personal use, and also controls the Treasury, the largest allowance paid to any Sultan in the Federated States is $£ 6000$ a year, which is about the equivalent of the allowance enjoyed by the Sultan of Pêrak. As already stated, the remarkable results obtained in the Federated States are mainly due to very liberal expenditure on useful and profitable works of development, while observing a wise economy in other directions. In Johore an almost exactly opposite system has been adopted, with the result that while the Federated Malay States have, in the last thirty years, made a progress which can fairly be gauged by an advance in revenue from, say, half a million dollars to twenty-two million dollars, Johore has made comparatively small progress in real development, and the revenue has not increased in anything like the same proportion as in the neighbouring States. So to-day the Sultan of Johore's personal allowance is said to be $\$ 240,000$ a year, out of a revenue of less than one and a quarter million dollars, while the Sultan of Pêrak's allowance is $\$ 50,000$ a year, out of a revenue of about twelve million dollars. It is necessary to emphasize this comparison for two reasons: first, because it might be thought that the rapid development of the Federated Malay States is not specially due to the administrative methods employed there; and, secondly, because comparisons have been drawn between English and Malay methods of administration, sometimes suggesting that the latter, as exemplified in Johore, are preferable.

In describing the acquisition of Pinang and Province Wellesley, in the early chapters of this book, frequent references were made to Kĕdah, and I need not now again describe its position. It is a considerable State with a 
large Malay population, chiefly engaged in the cultivation of rice. The Lankâwi Islands, and the States named Perlis and Sětul, are under the Kĕdah administration, and that, again, is subject to the instructions of a Siamese Prince in Bangkok, who holds the post of Minister of the Interior.

Before ever the British Government intervened to restore order in the Southern Malay States, Kědah had, by the efforts of its Malay Sultan and chiefs, attained to a degree of order and development which placed it far ahead of any of the States yet named. The chief village, a small but regularly-laid-out and tidily-kept place, called Alor Star, is some miles up the main river of the country. From this village ran a good road, with the river, bordered by houses and orchards, on one side, and a wide expanse of rice fields broken by islands of palm groves on the other. It was said, then, that the road extended for sixty miles towards the Siamese State of Senggôra, in the north of the Peninsula, but the road probably became a mere cart-track as soon as it passed the limit of cultivated fields, and I can say, as the result of personal observation, that ten miles from Alor Star the bridges had either never been built or had disappeared. For all that, the country was highly cultivated within a radius of five to ten miles round Alor Star; the Sultan was a just and upright man of intelligence, and his officers were full of good intentions; his chief minister was a man of real energy, and the people seemed happy and contented. The Siamese interfered very little in Kĕdah, and though the revenue raised must have been small, the country was not in debt. Since then, though the Chinese population has considerably increased, while tin mines have been opened and the revenue farms have yielded much larger sums, the present Sultan has contracted heavy debts, and the Siamese Government have quite recently come to his assistance with a considerable loan. It is, perhaps, not surprising that, under these 
circumstances, the Siamese Government are exercising a larger control in the administration of this State and its dependent islands and provinces. Here, again, is the opportunity of making a useful comparison between the administration of a Malay State, which has been under Siamese control since I82I, and the States where British influence has been exercised for thirty years. It is not suggested that the Siamese Government interfered with the government of Kĕdah to any great extent; but, when that is granted, the connexion with Siam has not proved of any

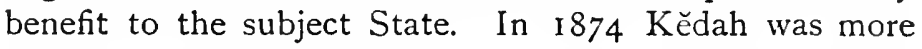
advanced in its institutions, in the observance of order, the well-being of its people, and the general development of the country, than any other State in the Peninsula. The then Sultan of Kĕdah, his brothers, and the chiefs who assisted him, were highly intelligent, and the country was free from debt. After thirty years of slow progress, including some mining development and an increase in the revenues, there is no striking improvement to rote; no important new works, no great increase in population, very slight extension of the town Alor Star; but the countryor the Sultan-has contracted a considerable debt. The amount has been stated as about $\$ 750,000$; in any case it is probably larger than the debt of either Pêrak, Sělangor, or Nĕgri Sĕmbilan in I874. There is no reason to suppose that Kĕdah is less rich in resources than the Federated States, and thirty years ago it was in a much better position than any of them. Kĕdah has had no internal trouble, no war; but it has suffered from feeble administration and the expenditure of revenue and borrowed funds in private extravagance. Therefore Kĕdah, which thirty years ago had no debt, now is in debt and has nothing to show for it. The Federated States, which thirty years ago had debts, now possess a balance of twenty million dollars, and they have great works of development to show where the rest of their revenues have gone. 
If I seem to over-emphasize these points, and draw comparisons which sound invidious, the facts must be insisted upon, for if they have ever been fully recognized-and I doubt it-they have been forgotten. As for the comparison, that also is a necessary part of the story, because casual visitors to the Federated States would conclude that what they see there is quite normal, and even residents as near as Singapore are, some of them, convinced that the Malay States are so rich in resources that they have naturally grown to their present condition of development and prosperity, and the work of government has been merely to sit still and chronicle the process of advancement from year to year. The exact opposite is the truth, for nothing but persistent effort in the right direction, foresight, courage, tact, and the other qualities necessary for dealing with such a difficult problem, could have achieved so great a success.

In recording events, it is a mere detail that I watched the process of Malay evolution at close quarters. That is, however, an added reason why I cannot omit from the story any facts which will assist the reader to form an accurate opinion on the policy pursued, from whatever aspect it is regarded.

Special circumstances, already fully explained, led to British intervention in four of the central States, and an impartial judgment on that experiment is greatly assisted by the fact that it is possible to compare the results obtained with the progress made in a practically independent Malay State, in the immediate south of the Federation, and with the same in another Malay State under Siamese suzerainty, in the immediate north. If it were not beyond the scope of this book, the comparison might be carried much farther afield-to Burma, Tenasserim and Siam, to the Netherlands Indies, to Sarâwak and British North Borneo, to the French possessions in Cochin China, and to the Philippines. All these countries have 
their own systems of administration, and in all there were, perhaps still are, conditions similar to those which prevailed in the Malay Peninsula thirty years ago. It would be very interesting to compare the methods of government adopted in each place and the results obtained. If such a comparison were made, the Federated Malay States need not fear it.

North of Kĕdah there are several small coast States, of which Rendong is probably the most important. They are under Siamese control, and are administered, on Siamese methods, by officials in the service of that Government. Our only knowledge of them is gleaned from the annual reports of a British Consul, who makes occasional visits to the places on the west coast of the Peninsula, north of Pinang. From what he has been able to see, and the impressions left on his mind, it would not appear that there is evidence of very rapid development, or very enlightened administration in Rendong, Tongkah, and Junk Ceylon. On the opposite coast of the Peninsula, in about the same latitude, there is a small State called Petâni. A hundred years ago or more, Petâni, then an important country, was conquered by the Siamese, and, probably to save themselves trouble and minimize any idea of rebellion, the original State has been divided into seven small States, each with a separate Raja or chief, who administers his charge under the authority of the Chaukun of Senggôra, a State originally Malay, but where the Siamese element is now greatly in the ascendant. The seven divisions of Petâni are: Petâni, Sai, Liggeh, Jâlor, Jĕring, Nongchik, and Rĕmân, on the borders of the northern territory of Pêrak. Owing to domestic differences and neglect of their proper duties, the Pêrak authorities allowed the Raja of Rĕmân to push his outposts down the Pêrak River, till, at last, it was discovered that a great piece of territory had been quietly absorbed by their neighbour. As Rèmân was under the protection 
of Siam, the occupation had to be treated seriously, and one of the very earliest complaints of the Sultan and chiefs of Pêrak, to the first British Resident, was in connection with this northern territory. After nearly twenty years of negotiation a compromise has been arrived at, with the help of the British Foreign Office, and a portion of the lost province has been restored to Pêrak by a definition of boundaries.

South of Petâni, between the eastern boundary of Pêrak and the China Sea, lies the large and populous Malay State named Kelantan.

Kelantan is a sunny country on the east coast of the Malay Peninsula, six degrees north of the Equator. It is drained by a considerable river, shallow throughout its length, with a delta and several mouths, whose position is constantly changed by the rush of the China Sea battling for six months of the year against the outcoming water and a sandy shore. Twelve miles up the river, on its right bank, is a considerable Malay town, with over ten thousand inhabitants, ruled by a Malay Sultan and his various chiefs, all of whom are settled in houses of some pretension in and about Kôta Bhâru.

The people of this place have certain peculiar customs, of which it may be mentioned that, though they are Muhammadans, the women move about as freely as the men. They mind the shops and deal with customers; they wear the silk sârongs for which Kelantan is famous, and they do as much carrying and marketing, gossiping and field work as their fathers, husbands, brothers, and lovers. That is one striking peculiarity of the place, and another is that Kôta Bhâru is given up to various forms of relaxation in a way unknown in any other State in the Malay Peninsula. There is the season for bull-fights and the season for ram-fights; the boat-racing season, the cockfighting season, and the season when every one who is any one goes down to the mouth of the river, camps on 
the great stretches of sand, which divide the fresh waters of the river from the salt waters of the sea, and there they disport themselves after their own fashion. The occasion of this festival for sea-bathing, boat-sailing, fish-catching, and general junketing is the close of the north-east monsoon, when the China Sea ceases to lash itself furiously against the east coast; when its mighty roar dwindles down to the cooing of the tiny silver-crested waves, and the people of the land feel that they are no longer prisoners, and can set their red and white and orange and chocolate-coloured sails and skim out over the gleaming waters to wooded islands and deep-sea fishing-grounds. There are few more fascinating pictures than the Kelantan fishing-fleet, in all the glory of strange hulls, mat and cloth sails of every hue and quaint design, standing out to sea from the river mouth at daybreak. The sun, just rising above the horizon and throwing shafts of light through the lifting mist across the silver grey of the waveless sea; the boats, several hundreds in number, gliding in a fairy-like procession from closest foreground to the utmost limit of vision. They make a marvellous study in colour and perspective, and parallel with the line of their noiseless progress lies the shore-a long stretch of grey-green wood and yellow sand, divided from the sea by a narrow ribbon of white wave.

That is Kelantan from the sea. Twelve miles of clear island-studded river, winding between rice fields and palm groves, form the highway from the river mouth to the capital. The Sultan's astâna or palace, which, with its dependencies, surrounds on three sides a court of sand, is closed on the fourth by a wooden palisade with one great central gate flanked by smaller gates on either side. A second and similar set of gates forms a further enclosure, about a hundred yards nearer the river. From these outer portals to the river stretches a long straight road, and, on occasions of great ceremony, 
the visitors whom the Sultan delights to honour will find this road lined, on both sides throughout its entire length, by spearmen, while the principal chiefs and a great posse of retainers escort the guests from the landing-stage to the hall of audience, where the Sultan receives them. Beyond the palace, the town, the houses and gardens of rajas and chiefs, the country is highly cultivated as far as the eye can reach. Immense quantities of cocoanuts are grown and made into copra, all of which is exported to Singapore.

South of Kelantan again, and immediately north of Păhang, is the independent State of Trĕnggânu. By the Treaty of Bangkok, concluded in 1826 , between the English and Siamese, it was mutually agreed as follows: "Siam shall not go and obstruct or interrupt commerce in the States of Trĕnggânu and Kelantan. English merchants and subjects shall have trade and intercourse in future with the same facility and freedom as they have heretofore had, and the English shall not go and molest, attack, or disturb those States upon any pretence whatever."

From the time that Treaty was made till the end of the century, the Siamese lost no opportunity of seeking to impose their authority upon the Sultans of Kelantan and Trĕnggânu, always pressing Kelantan more firmly than Trĕnggânu, in proportion as Kelantan was nearer to Petâni and Kĕdah, two Malay States already under Siamese control.

Nothing less than a book could deal fully with the whole story of the assertion of Siamese claims in regard to these two States, and the replies of British Governors of the Straits and others who contended for the independence of Kelantan and Trĕnggânu, but I must be satisfied with trying to give the briefest intelligible account of the dispute and its settlement, so far as the question has been settled. 


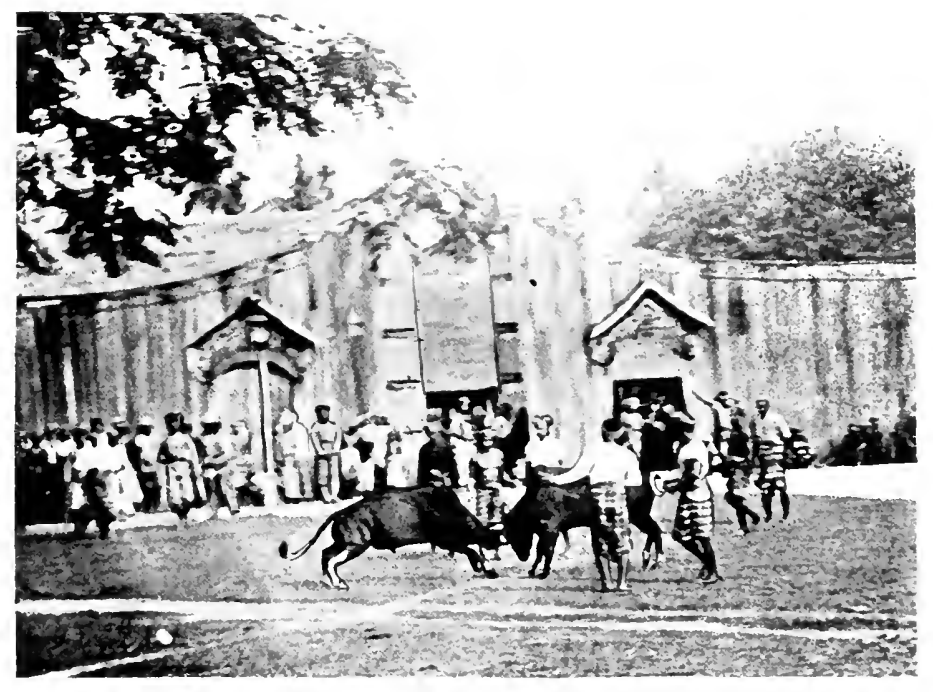

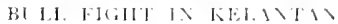

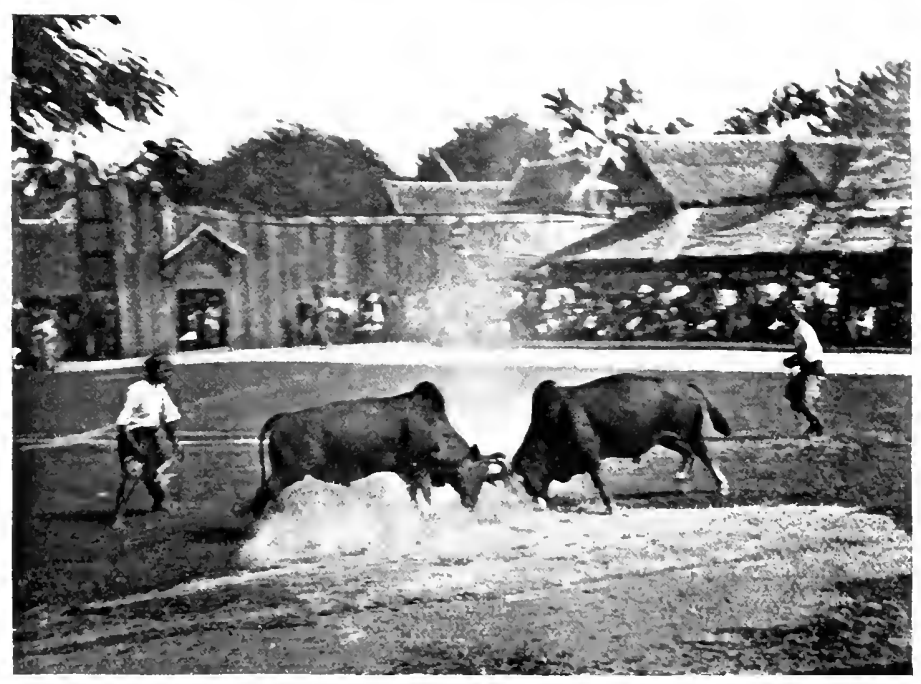

A BUI, FlOHI IN KELANAAX 

When Raffles finally left the East he wrote a long and interesting letter of instructions to Mr. John Crawford, the Resident of Singapore. The letter is dated 7 June, I 823, and having discussed all local questions, Raffles wrote as follows :-

"Having given you these instructions as far as regards your situation as Resident of Singapore, I am desirous also of calling your attention, on some points, to the line of policy which it appears to me advisable for you to pursue more generally in your political capacity in the Archipelago. On this subject one of the most material points is our political relations with Siam and the Malayan States alleged to be tributary to it. On this point it is incumbent upon me to state with candour that the policy hitherto pursued by us has in my opinion been founded on erroneous principles. The dependence of the tributary States in this case is founded on no national relation which connects them with the Siamese nation. These people are of opposite manners, language, religion, and general interests, and the superiority maintained by the one over the other is so remote from protection on the one side or attachment on the other, that it is but a simple exercise of capricious tyranny by the stronger party, submitted to by the weaker from the law of necessity. We have ourselves for nearly forty years been eye-witnesses of the pernicious influence exercised by the Siamese over the Malayan States. During the revolution of the Siamese Government these profit by its weakness, and from cultivating an intimacy with strangers, especially with ours over other European nations, they are always in a fair train of prosperity; with the settlement of the Siamese Government, on the contrary, it invariably regains the exercise of its tyranny, and the Malayan States are threatened, intimidated, and plundered. The recent invasion of Kĕdah is a striking example in point, and from the information conveyed to me it would 
appear that that commercial seat, governed by a prince of most respectable character, long personally attached to our nation, has only been saved from a similar fate by a most unlooked-for event. By the independent Malayan States, who may be supposed the best judges of this matter, it is important to observe that the connexion of the tributary Malays with Siam is looked upon as a matter of simple compulsion, Fully aware of our power, and in general deeply impressed with respect for our national character, still it cannot be denied that we suffer, at the present moment, in their good opinion by withholding from them that protection from the oppression of the Siamese which it would be so easy for us to give; and the case is stronger with regard to Kèdah than the rest, for here a general impression is abroad amongst them, that we refuse an assistance that we are by treaty virtually bound to give, since we entered into a treaty with that State, as an independent power, without regarding the supremacy of Siam or ever alluding to its connection for five-and-twenty years after our first establishment at Pinang. The prosperity of the Settlement under your direction is so much connected with that of the Malayan nation in its neighbourhood, and this again depends so much upon their liberty and security from foreign oppression, that I must seriously recommend to your attention the contemplation of the probable event of their deliverance from the yoke of Siam, and your making the Supreme Government immediately informed of every event which may promise to lead to that desirable result."

At the same time Raffles wrote as follows to the Supreme Government :-

"The information which must be before the Supreme Government from Prince of Wales Island, as well as in the reports of the late Mission to Siam, renders it unnecessary that I should enter at any length on the actual 
condition of the Malay States in the Peninsula; but I have thought it advisable to direct Mr. Crawford's attention to the subject, with the view of his keeping the GovernorGeneral in Council regularly advised of the progress or otherwise of the Siamese influence among them.

"The conduct and character of the Court of Siam offer no opening for friendly negotiations on the footing on which European States would treat with each other, and require that in our future communications we should rather dictate what we consider to be just and right, than sue for their granting it as an indulgence. I am satisfied that if, instead of deferring to them so much as we have done in the case of Kĕdah, we had maintained a higher tone and declared the country to be under our protection, they would have hesitated to invade that unfortunate territory. Having, however, been allowed to indulge their rapacity in this instance with impunity, they are encouraged to similar acts towards the other States of the Peninsula, and if not timely checked may be expected in a similar manner to destroy the truly respectable State of Tringanu, on the eastern side of the Peninsula.

"The blockade of the Menam River, which could at any time be effected with the cruisers from Singapore, would always bring the Siamese Court to terms as far as concerns the Malay States, and from the arrogant and offensive tone recently assumed by the Siamese, some measure of the kind will, I fear, ere long become indispensable, unless the possible apprehension of our adopting such a measure may bring them to terms of more accommodation than they have yet shown."

Those words, coming from a man of very exceptional character and ability, who for nearly twenty years had devoted himself to the study of Malay affairs, who had for five years governed Java and all its dependencies with distinguished success, and had selected and secured Singapore for the British Crown, might have been expected to 
carry weight. But, as so often happens, the voice of the man on the spot was disregarded ; Raffles was suspect, and his immediate masters were the directors of a trading company, the objects of which were profit and not the protection of weak but friendly races from ambitious neighbours. Had Raffles known the commercial value of the Malay States and made that his plea, the East India Company might have been more ready to listen to him. If his representations had any effect at all it must be found in Art. 12 of the Bangkok Treaty of 1826 , so far as it provides that neither British nor Siamese shall interfere in Kelantan or Trěnggânu.

The weight of numbers, greater unity, and some military discipline had enabled Siam to overrun Petâni and Kĕdah, and impose on those States such control-it could hardly be styled government-as was thought necessary. What that meant to the Malays is briefly but accurately stated in Raffles' sentence: “These people are of opposite manners, language, religion, and general interests, and the superiority maintained by the one over the other is so remote from protection on the one side or attachment on the other, that it is but a simple exercise of capricious tyranny by the stronger party, submitted to by the weaker from the law of necessity."

From I 826 till I 862 nothing particular happened; but in that year the Governor of the Straits Settlements, Colonel Orfeur Cavenagh, found it necessary to protest against a proposal of the Siamese Court to send to Trĕnggânu the ex-Sultan of Lingga, whose design to make an attack on Păhang, and so disturb the peace of the Peninsula, was notorious. At first this remonstrance, made after a personal complaint from the Sultan of Trěnggânu to the Governor, was successful; but some months later the ex-Sultan of Lingga was sent to Trĕnggânu in a Siamese steamer, and, as Colonel Cavenagh's renewed and energetic protest and request for the ex- 


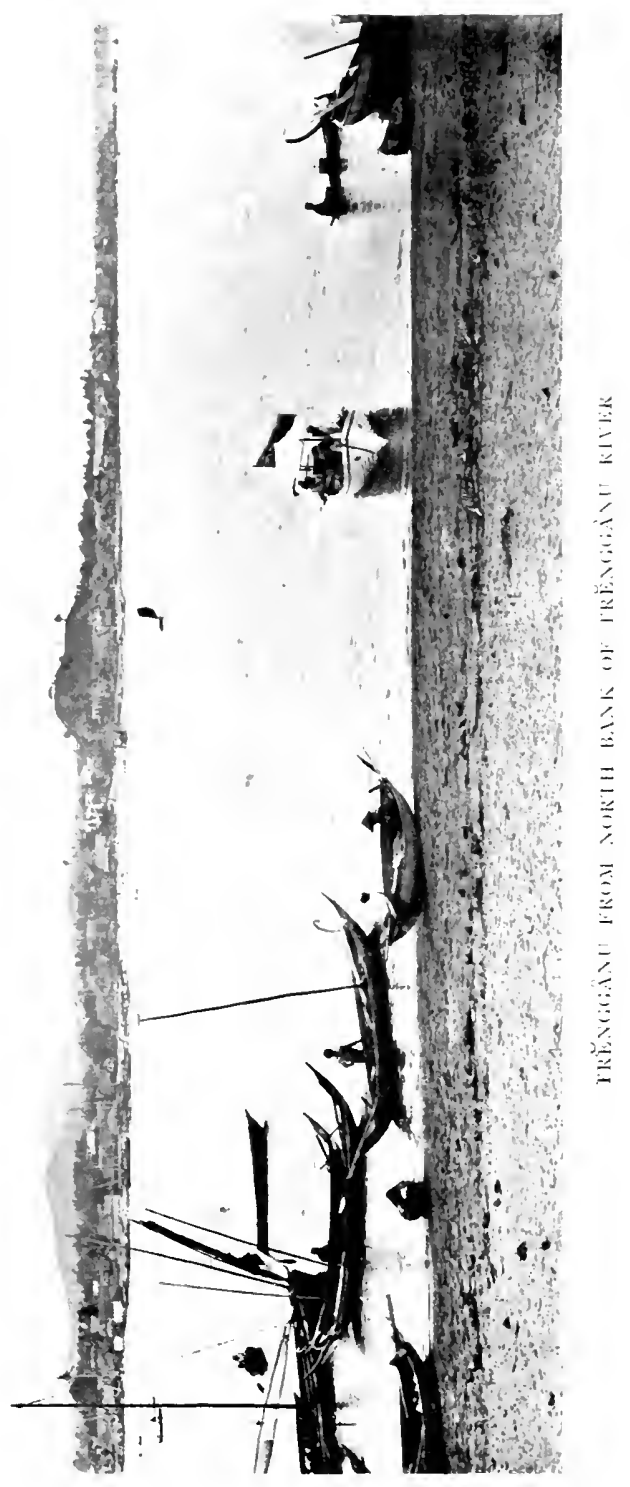



Sultan's removal met with nothing but promises which were not performed, the Governor deputed two vessels-ofwar and a Straits Government steamer to Trĕnggânu to demand the immediate return of the ex-Sultan of Lingga to Bangkok; but the demand was not complied with in the time allowed, the Trĕnggânu fort was shelled, and the Court of Bangkok ultimately removed the ex-Sultan. The shelling was merely a demonstration, and no one was hurt.

In a narrative of these proceedings, prepared by Governor Cavenagh and transmitted to Calcutta, the following are the three first paragraphs:-

"Trĕnggânu is an independent Principality, situated on the east coast of the Malay Peninsula, the ruler of which, as is often customary with weak Oriental States, dispatches a periodical Embassy with presents to his powerful neighbour, the King of Siam; but he has never acknowledged obedience to the latter, and has always refused to do him personal homage.

" 2. When the Treaty of I 826 was concluded between Great Britain and Siam, the independence of Trĕnggânu and the adjoining State of Kelantan was mutually guaranteed by Article 12. This Article is still in force, having been confirmed by the Treaty of 1856 , whilst Article IO, which specially referred to the countries and provinces under the authority of Siam, was, by the same engagement, in a great measure abrogated.

" 3. Even as far back as 1785 , the Sultan of Trĕnggânu has been in direct communication with the British authorities in the Straits, and has on one or two occasions actually solicited their aid to enable him to resist the Siamese when threatened with attack; he has, at all times, been recognized as an independent chief, and neither in 1850 , when he dispatched an embassy to Java, with a view of cultivating friendly relations with the Dutch, nor in $185 \mathrm{I}$, when his treatment of some British subjects became the matter of 
investigation, were any pretensions to exercise the slightest control over his proceedings, or to interfere on his behalf, advanced by the Siamese Court."

Apparently, then, it was not till I 862 that Siam put forward any pretensions to the exercise of authority in Trĕnggânu, and then the claim was based upon the fact that, in two instances, one the complaint of a Chinese trader "relating to some matters in connexion with Kelantan," and the other an inquiry from the Governor of the Straits whether "the report that the Government of Siam intended to depose the Raja of Trênggânu and place the ex-Sultan of Lingga in his stead were true or not," reference had been made to the Siamese Government through the British Consul at Bangkok! Nothing more was heard of the Trĕnggânu affair, and in the succeeding thirty to forty years nothing very definite happened, but to those interested in Malay affairs it was evident that Siam was quietly but persistently endeavouring to establish political influence, and even active control, in Kelantan, while attempts of the same nature met with no success in Trĕnggânu.

Kelantan marches with Petâni on the north, and is no great distance from Senggôra; it was therefore not difficult, in a long course of years, for the Siamese to make their influence felt in an adjoining State which had no means of resistance, and no friend but Britain to support its independence. Ever since the Straits became a Colony the Governor has, at uncertain intervals, visited these East Coast Malay States. On those comparatively rare occasions, often several years apart, the Sultans of both Kelantan and Trĕnggânu invariably declared their independence. In the case of Kelantan the wish was probably father to the statement, for it is certain that Siam gradually established a considerable influence in the country, though until 1902 there was no treaty or engagement of any kind to show that Kelantan had parted with 
any of its independence. In Trĕnggânu, perhaps because it was farther away, perhaps because it is less developed, has a smaller population and a much smaller revenue, assuredly because the Sultan is a very obstinate man, Siamese blandishments met only with a polite reception and no result. To this day the Sultan maintains his absolute independence and exercises it; no Siamese official has ever obtained a footing in the State, and the Sultan declines to sign any document which might in any way compromise his liberty of action.

The stranger may ask why Siam, with a very indifferently developed kingdom of its own, with large subject provinces on the east and south, quite sufficient to occupy for many years the best attentions of a vigorous, intelligent, and progressive Power (one cannot say people, for they do not count in such matters) should have taken the trouble to try to absorb distant and foreign territories inhabited by a people of different race and religion, with whom they have nothing in common, and who cordially dislike them. The answer probably is, that having dealt with Kĕdah and Petâni, the Court of Bangkok saw no reason why they should not absorb as many more Malay States as possible, especially as the rulers could make no resistance by force, and the value of adjoining States had been amply proved when developed under British protection. These were good enough reasons, but it so happened that at this very time France was sorely pressing Siam on the east, where the Native Government made a series of grave mistakes, for which it has had to pay verv dearly. France having settled herself in Saigon, began the process of "peaceful penetration," northward to Annam and Tongking, westward to Cambodia and Luang Phrabang. It is difficult to speak with confidence on matters of dispute between two foreign Powers, when the territory concerned is so remote and boundaries are so imperfectly defined. Probably it would not be incorrect to say that 
Siam was not satisfied with claims she could establish, but went beyond them and asserted rights which France was not willing to recognize. Then, having hitherto dealt with only one European Power, Great Britain, and found that, in those dealings, the assertion of shadowy claims and refusal to consider proposals for compromise constituted a very useful form of diplomacy, it was probably imagined that the same tactics would serve equally well with France. And so they did for a time. Curiously enough, however, there was a limit to French endurance, and once reached, the Government of the Republic adopted the plan suggested by Stamford Raffles, and sent two gunboats up to Bangkok, while the Menam was blockaded and, our interests being threatened, this country was almost drawn into war with its nearest neighbour. Instead of agreeing with their adversary quickly, while he was in the way to agree, and 'so obtaining very much better terms, the King of Siam, or his advisers, thought it would be more clever and more profitable to play off the French, on the east, against the British in the south, and vice versa; and instead of giving way anywhere, to make extended claims both eastward and southward. The awakening was sudden and unpleasant, and the result, as regards France, is that not once, but several times, Siam has had to abandon claims and give up territory over which she had long exercised sovereign rights. Finding on one border an uncompromising Power, which had forced its way to the Mekong and imposed certain unpleasant conditions in regard to territory on the other bank of that river, the idea seems to have been conceived that losses of territory and influence on the east might be made up by additions of territory and influence in the south, where the only Power able to protect the Malays could be treated as a negligible quantity, or induced to further the scheme. The successful game of playing off France against England was, or ought to have been, at 
an end when those Powers made, in 1896 , a treaty, guaranteeing the integrity of Siam proper, and declaring their own respective spheres of influence. Even since that treaty, France has managed to extend her authority at the expense of something more than Siamese pretensions, while British complacency has permitted the crystallization of Siamese claims in the south to the extent that Siamese protection of the Malay State of Kelantan has been recognized. In one way this step is a benefit to Kelantan; for it is better to know what your position is, better to have some definite authority, than to live in the constant fear of trouble, of the deposition, the banishment, even the imprisonment of the Ruler (as occurred so recently in the case of the Raja of Petâni), and the possible fall of the State from a position of independence to the rank of a province governed by a foreign official.

In a paragraph of Raffles' instructions to Major Farquhar, Resident of Singapore, Sir Stamford, writing on 6 February, 18I9, said: "With regard however to those States which have not yet fallen under their [that was the Dutch] authority, it is justifiable and necessary that you exert your influence to preserve their existing state of independence. If this independence can be maintained without the presence of an English authority, it would be preferable, as we are not desirous of extending our stations; but as from the usual march of the Dutch policy, the occupation of Tringanu, and the extension of their views to Siam, may be reasonably apprehended, a very limited Establishment in that quarter may become ultimately necessary."

Supposing that Raffles was right, not only for his time but till now, and that Great Britain had no desire to extend her stations in Malaya, her interest in the "open door" has always been sufficiently strong to make her prefer to see a friendly State preserve its independence 
rather than fall under an influence with any selfish or exclusive tendencies. No Power can dispute the factwhich France has declared by treaty-that the Malay Peninsula is a British sphere of influence. Any country but Great Britain would long ago have extended its protection over all the States, including Kelantan and Trĕnggânu, and they would have been glad to accept the position. That there has been no "land-grabbing" is evidenced by the fact that Johore still manages its own affairs. Singapore has for years been the market for all the east coast, and it will remain so. Practically the whole trade of Kelantan and Trĕnggânu is with Singapore, and, till quite recently, it was all carried in British steamers owned in Singapore. So long as those conditions remain the Imperial Government may prefer to take no further responsibilities. From what we now know of the Peninsula, it would be better for both Malay and British interests that these States should be developed and administered on the lines which have proved successful in the Federated States; and it would have been natural and straightforward to say so and arrange accordingly. It is quite understandable that the States should be allowed to work out their own salvation or damnation as best they may. It is, however, difficult to see on what grounds Siam should be encouraged or allowed to absorb Malay States against their will. It is the Malay habit to seek and lean upon a powerful neighbour; weak States naturally fall into that position. It might, however, be hard to say what benefit a Malay State and people would be likely to derive from a course of Siamese administration. If it is urged that the Malay is indifferent in the matter of masters, the case of Achin seems a strong argument to the contrary, and, as a matter of fact, the Malay is very tenacious of authority, very slow to make friendships and very reluctant to change them. The Achinese are Malays, and if a small State in Sumatra prefers to fight for thirty 
years and then put its women and children in the battleline sooner than accept Dutch masters, it is very improbable that a Malay State in the Peninsula would willingly accept Siamese masters.

Raffles saw the case in its true light, but it is fair to assume that a British Foreign Secretary in I890, or later, would not be conversant with Raffles' opinion on the subjection of Malays to Siamese. It is also rather an article of British official faith that, in questions of Imperial interest, people on the spot are bad judges. There is much to be said for this creed, but it would not be difficult to show that it does not meet every case. It was, perhaps, a mistake to give up Java; it was certainly a mistake to contract ourselves out of Sumatra; and if there are reasons for allowing Siam to increase her territory and her revenues at the expense of the Malays, they have never been publicly stated. The British Government seems to have held the mistaken view that the smallest extension of British influence in the Malay Peninsula might serve as a pretext for new French claims against Siam. It was clearly to the advantage of Siam to suggest and encourage that view, and though the Government of Bangkok failed to influence France by similar considerations, and the Republic has pursued its own policy and driven Siam back step by step, England not only observed a rigorous abstention, but raised no objection to the prosecution of Siamese designs on friendly Malay States whose outside interests have always been, and must remain, closely connected with the Straits Settlements. The reader can form his own opinion on the action of the East India Company in abandoning Kĕdah to what Raffles styled the rapacity of Siam. There is a very wide difference between any trading company, however great, and the Imperial Government. It is, for instance, difficult to imagine that the British Government, possessing as it does a complete knowledge of all the circumstances, 
would stand aloof and allow the Sultan of Trĕnggânu to be forced into subjection against his expressed determination to maintain his independence, especially while the administration of the country offers no pretext for intervention.

The writer desires to refrain from any criticism of Siamese methods of government, either in Siam or in the dependent provinces. An opinion expressed by Sir Stamford Raffles has been quoted, because it is confirmed by the greater knowledge now possessed of things Malayan and things Siamese; but it is sufficient to let the question rest on general principles. The Malay Peninsula is a British sphere of influence, as much as Sumatra is Dutch, or Cambodia French, and while it does not appear that Siam has ever had either excuse or invitation to justify the extension of her influence and authority in the Malay States, and neither Petâni nor Kĕdah have benefited by their long connexion with Siam, British protection has been invited and the results of our intervention and influence in the Federated States are sufficient reason to extend it, or, where the Malays prefer to be left alone, to shield them from outside interference.

These considerations are important as concerning high principles and the welfare of the Malays, who not only cannot make themselves heard, but may be profoundly ignorant of the conclusion, by second and third parties, of arrangements which will probably decide the course of their future existence. They are important to us on other and more selfish grounds, because the trade of all the Malay States north of Pinang has, for a century, been practically confined to that Settlement, just as the trade of the East Coast States is centred in Singapore. More important still is a new factor which has grown out of the recent development of the States under British Protection, including the State of Johore. The Main Trunk Railway from Pinang to Singapore will shortly be completed, and the question of an east coast line, to connect 
Păhang, Trĕnggânu, and Kelantan with this system, and with the markets of the Straits Settlements, must arise in the near future. If the east coast States are to be developed and those countries are to enjoy a similar prosperity to that already established in the western States, railway communication is a necessity, because for nearly half the year, during the prevalence of the north-east monsoon, the coast is dangerous for those small steamers which alone can navigate its shallow waters. Trĕnggânu and Kelantan have no funds to meet the cost of such an undertaking; for many years all their resources will be required for roads and other less expensive but equally necessary works. The Federated Malay States have the money, the experience, and the men to do for Trĕnggânu and Kelantan what they are now doing for Johore, and, in supplying a better and more reliable means of communication between these States and the Singapore market, there will be no diversion of trade, only a new route to that port which, by its position, its facilities, and its freedom from restrictions, has attracted the commerce of neighbouring places for upwards of a century.

The East India Company has given place to the British Government, and the Malays of the Peninsula have in the last thirty years acquired a fairly accurate knowledge of the extent of British power, the value of British help, the character of British officers, and their methods of administration. British prestige to-day is a reality in the Peninsula; it is something so good and so much respected by the Malays that it imposes on the British Government a responsibility to consider how it will be affected by their action in any question which nearly concerns the welfare of the people who have come to regard the King as the ultimate disposer of their destinies. No one who knows them doubts that their ambition is, as they put it themselves, "to take shelter beneath the British flag," and as that is their desire, so it is probably their ultimate destiny. 


\section{CHAPTER XIV}

HOW THE DEVELOPMENT OF THE MALAY STATES HAS AFFECTED THE NEIGHBOURING BRITISH COLONY, AND THE RELATIONS OF BOTH WITH THE COLONIAL OFFICE-THE SINGAPORE HARBOUR AND DOCKS-THE CIVIL SERVICE-THE MALAY ADMINISTRATOR-THE FUTURE OF BRITISH MALAYA

S any attempt to chronicle the rise and pro-
gress of British influence in Malaya must
necessarily deal first with the Crown Colony
infelicitously styled the Straits Settlements, so the record closes on the original point of departure. The colony already had many years of life, under greatly varying conditions, and an interesting history behind it when circumstances drove the British Government to consent to an extension of British control to a region till then unknown to the western world. The English character and special aptitude for solving difficult administrative problems has wrought something like a miracle in the Federated Malay States, and the inquirer will naturally ask what was the effect of this sudden development of the Malay States on a neighbour so close and so intimately connected with them.

The territory of this friendly rival may be said to lie wholly between Pinang and Singapore; it has grown in thirty years from practically nothing to a position of prosperity which places it ahead of all British Crown Colonies ; it has developed an annual trade of thirteen millions sterling, the whole of which passes through the colony; 


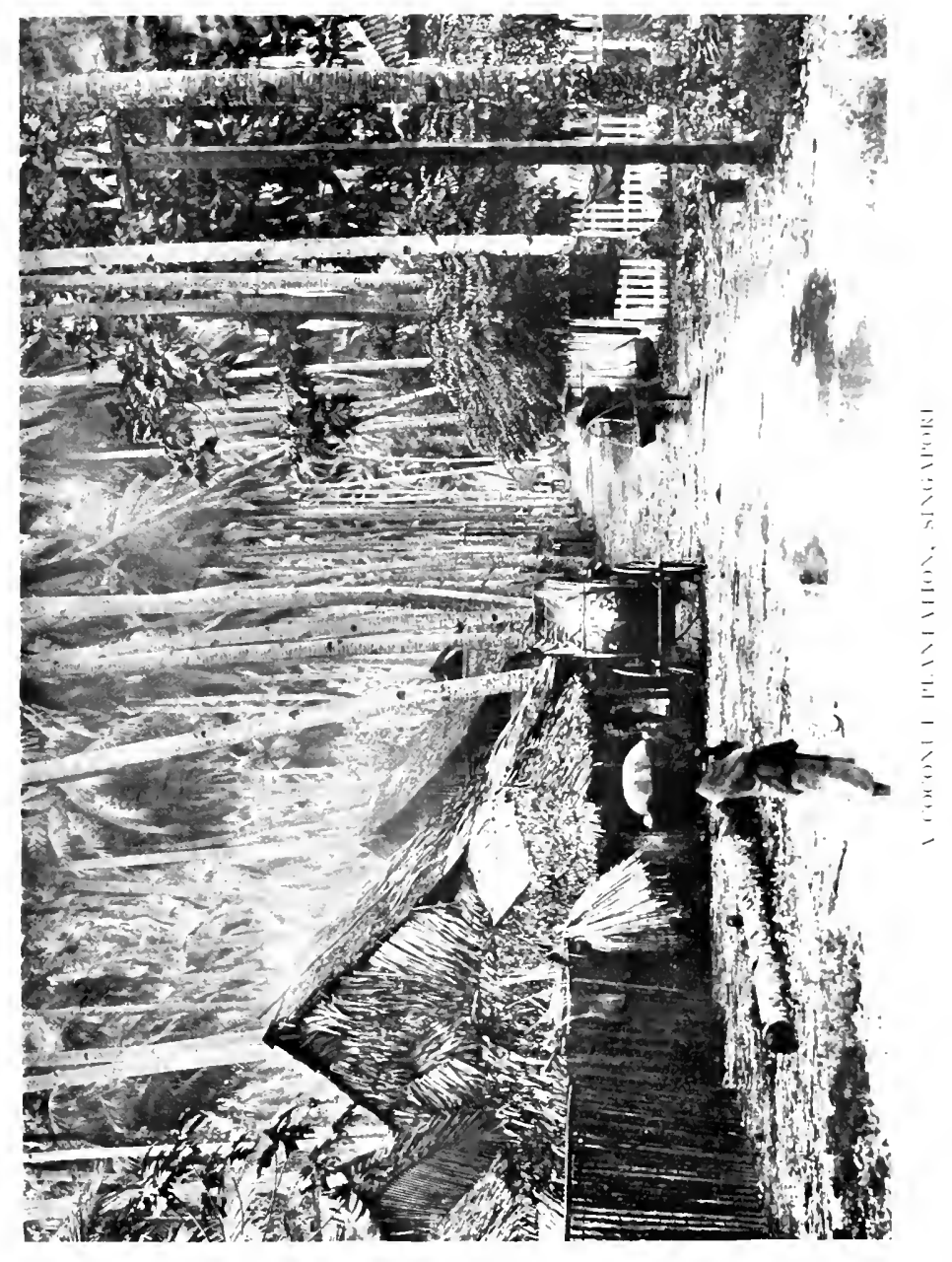



its population has advanced from under 300,000 to over 800,000 ; and the colony supplied from its own service some of the men on whom fell the burden of devising the system of administration which is responsible for the results obtained. These circumstances were certain to have a profound effect, and it is pertinent to ask whether the rise of the Malay States has injured or benefited the British possessions, and in what way.

The answer is that the colony has gained enormously and in every respect by the development of the hinterland. The effect of Malay expansion and the measure of the colony's gain can be judged by the following figures, showing the revenue, expenditure, and trade of the colony from the first full year of its existence as such, and then, at intervals of five years, from the commencement of the residential experiment.

STRAITS SETTLEMENTS

\begin{tabular}{|c|c|c|c|c|}
\hline \multirow[b]{2}{*}{ Year. } & \multirow{2}{*}{$\begin{array}{l}\text { Revenue in } \\
\text { Dollars. }\end{array}$} & \multirow{2}{*}{$\begin{array}{l}\text { Expenditure in } \\
\text { Dollars. }\end{array}$} & \multicolumn{2}{|c|}{ Trade. } \\
\hline & & & $\begin{array}{l}\text { Value of Imports } \\
\text { in Dollars. }\end{array}$ & $\begin{array}{l}\text { Value of Exports } \\
\text { in Dollars. }\end{array}$ \\
\hline I 868 & $I, 301,843$ & I, I 97, I 77 & 42, I I 9,708 & $37,993,856$ \\
\hline I869 & $1,313,046$ & $\mathbf{I}, \mathbf{1} 64,354$ & $43,986,222$ & $40,5^{8} 3,3^{22}$ \\
\hline 1870 & $1,378,748$ & $\mathbf{I}, 259,376$ & $54,449,388$ & $47,989,953$ \\
\hline $187 \mathrm{I}$ & $\mathrm{I}, 4 \circ 5,7 \circ 3$ & I, 254, I I I & $5^{6,016,66 \text { I }}$ & $5 \mathrm{I}, 807,60 \mathrm{I}$ \\
\hline 1872 & $\mathrm{I}, 53^{6,274}$ & I,296,3 I I & $6_{3}, 6_{50,222}$ & 62, I 49,329 \\
\hline 1873 & $\mathrm{I}, 5 \circ 2,094$ & $\mathbf{I}, 4$ I 5,828 & 64,795, I 35 & 60,3 I 2,143 \\
\hline 1874 & $\mathrm{I}, 45^{8,782}$ & I,679,2 20 & 67, x 17,979 & 62,643, r 95 \\
\hline I 875 & $\mathbf{I}, 53^{8,854}$ & $\mathrm{I}, 8 \circ 5,229$ & $63,137,7$ I 6 & $62,493,328$ \\
\hline 1880 & $2,361,300$ & $2, \circ 38,947$ & $83,718,1 \circ 3$ & $78,051,739$ \\
\hline 1885 & $3,508,074$ & $3,593, \mathbf{I} 49$ & I 10,356,796 & $100,513,222$ \\
\hline I 890 & $4,269,125$ & $3,757,69 \mathrm{I}$ & I $47,297,3$ I 7 & I $27,923,682$ \\
\hline 1895 & $4,048,360$ & $3,782,45^{6}$ & I 98,2 I 8,306 & I 72,974,953 \\
\hline I 900 & $5,386,557$ & $6, \circ 3 \circ, 744$ & $314,089,860$ & 262,6 × 7,345 \\
\hline I 904 & I $0,746,5$ I 8 & го, 848,989 & $3^{8} 3,942,088$ & 326, I 93,85 I \\
\hline
\end{tabular}


The first complete year under colonial regime was I868, and by 1874 , the year of the appointment of British Residents in the Protected States, the revenue of the colony had increased $\$ 150,000$ in round numbers. But in the very next year (1875), the first full year of the working of the new experiment, the colony's revenue went up $\$ 80,000$, and for the next three quinquennial periods there were substantial advances. The remarkable increase in 1904 was obtained by a revision of the conditions on which the excise farms were leased for a new period of three years; but in comparing the revenue returns of the Straits with those given for the Federation in chapter XII, the reader must bear in mind that the Malay States were answering to the spur of heavy expenditure on works designed to develop their rich resources, while the colony had settled down into its stride after eighty years or more of British government. Without an alteration in the basis of taxation the only causes likely to affect the colonial revenue will be a greater volume of trade and a larger population. The trade returns are certainly remarkable, even when due allowance is made for the constant depreciation in the gold value of the silver dollar. In the seven years from 1868 to 1875 the dollar value of trade rose from 80 to 125 millions, but for the three last periods of five years and the final period of four years the figures are 275, 371, 576, and 710 millions respectively. The last-named amount was equal to about 7 I millions sterling, and nearly one-fifth of it represents the value of real imports into and real exports from the Federated Malay States, for the trade of the colony is in the main a passing trade. The dollar value of the trade of the Malay Protectorate in 1905 was therefore more than equal to the dollar value of the entire trade of the colony in I 875 , and the handling of such a volume of imports and exports must mean employment and profit to a large number of Straits people of all classes and nationalities. 


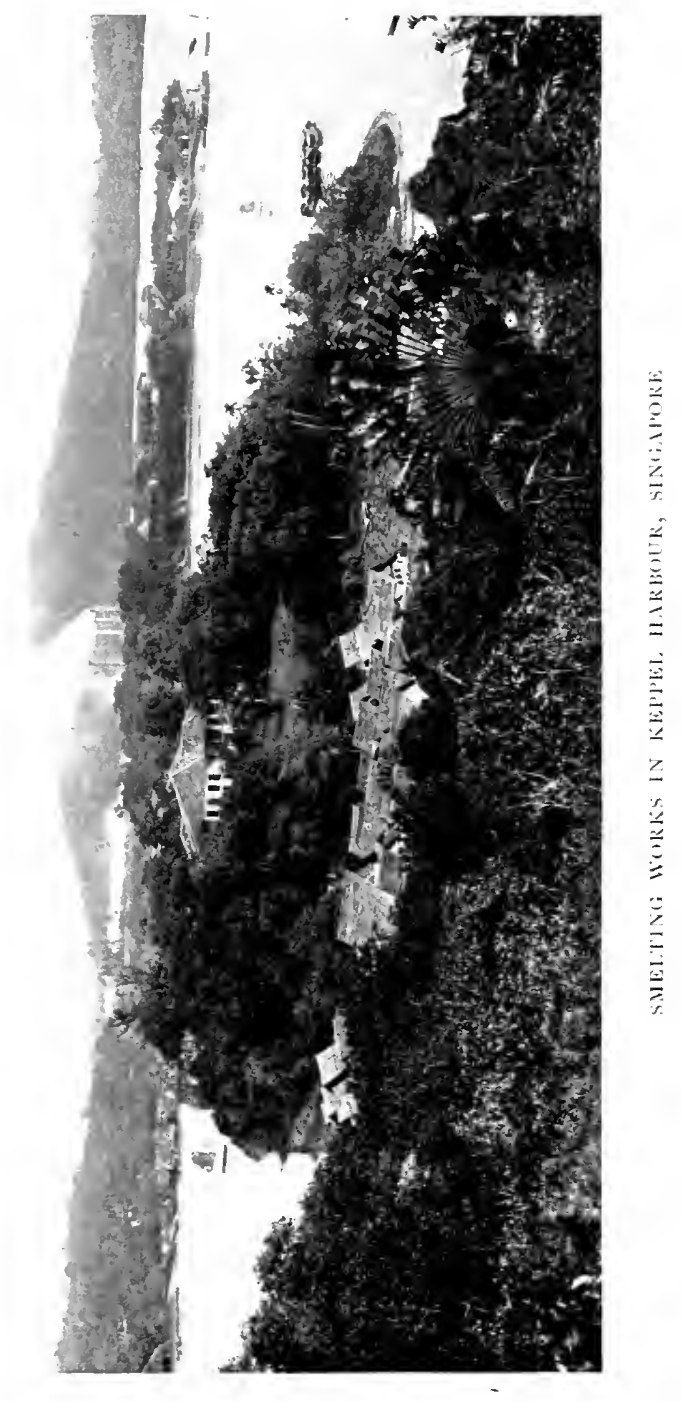



It may fairly be claimed that the issue of notes by the Straits Government is due to the Malay States, and the face value of the notes in circulation in 1904 exceeded I7 million dollars. The northern settlement (Pinang and Province Wellesley) has, since I900, been connected by railway with the Protected States, and, as the direct result of the impetus thus given to trade, large smelting works have been built in Province Wellesley, and an iron pier for ocean-going steamers has been constructed in Pinang. Similarly the fact that Singapore possesses the largest tin-smelting works in the world is due to the development of the Malay States. An American attempt to transfer this tin-smelting to American soil, and so obtain, in time, complete control of Malay tin production, was frustrated by imposing a prohibitive duty on the export of tin ore and giving an equivalent rebate on all ore smelted in the Straits Colony. Thirty years ago the European community of Singapore decided that a railway across the island must be immediately constructed, but there is something in the atmosphere of the place which raises objectors to every large scheme of improvement, even after the details have been practically settled. There is no other means of satisfactorily explaining the fact that this railway was only begun and completed within the last few years. The trade of Singapore has grown so rapidly that the Singapore River will no longer accommodate the immense number of cargo boats engaged in serving that portion of the shipping which makes use of the roads, or in conveying cargo by sea to and from the wharves at Tanjong Pagar and Keppel Harbour. After taking local evidence and consulting the most experienced harbour engineers, a scheme was adopted for providing Singapore with a protected harbour $\mathrm{I} 300$ acres in extent, with a long quay wall for the accommodation of coasting steamers, and a reclamation that would in time have paid almost the entire cost of the work. Just when it appeared certain 
that Singapore had satisfactorily solved the urgent question of finding shelter for the traffic and lying-in of cargo boats, but was also to secure protection and free wharfage for its considerable fleet of coasting steamers by a scheme that would pay for itself by the sale of reclaimed land, the usual objectors came forward to denounce the engineer's proposals as extravagant and needless, and if the Government adheres to its decision to carry out the work, or any modification of it, a great deal of valuable time has already been lost. If Singapore is to maintain its position as the premier port and market in the Archipelago it must keep abreast of modern requirements, and so improve the docks and harbour that it need fear no competitors. The town of Singapore now contains 250,000 inhabitants, and careful people have expressed the opinion that, with the continued development of the Malay States and the natural advance of a place so favourably situated, these numbers will in time reach a million. It is therefore necessary to look well ahead, to calculate the effect of present and future railway extensions, and not merely to apply a temporary remedy to relieve an ailment which is not the result of infirmity or decay, but the natural growth of a vigorous constitution.

Quite recently the Government wisely decided to take over the great wharf and dock establishment of the Tanjong Pagar Dock Company, and to spend the large sum necessary to extend the premises to meet the urgent requirements of the port. It is, however, difficult to understand the method adopted by the Colonial Office for determining the price to be paid to the Company, or to justify the heavy costs which will be thrown upon the colony by this policy. ${ }^{1}$

1 Since writing the above the award of the Umpire in the Tanjong Pagar Dock Arbitration has been made public. According to replies given by the Under-Secretary of State for the Colonies in the House of Commons, the effect is that the Straits Settlements has to pay about $£ 3,319$,000 to the Dock Company. The colony has also to pay the costs of arbitration which, 


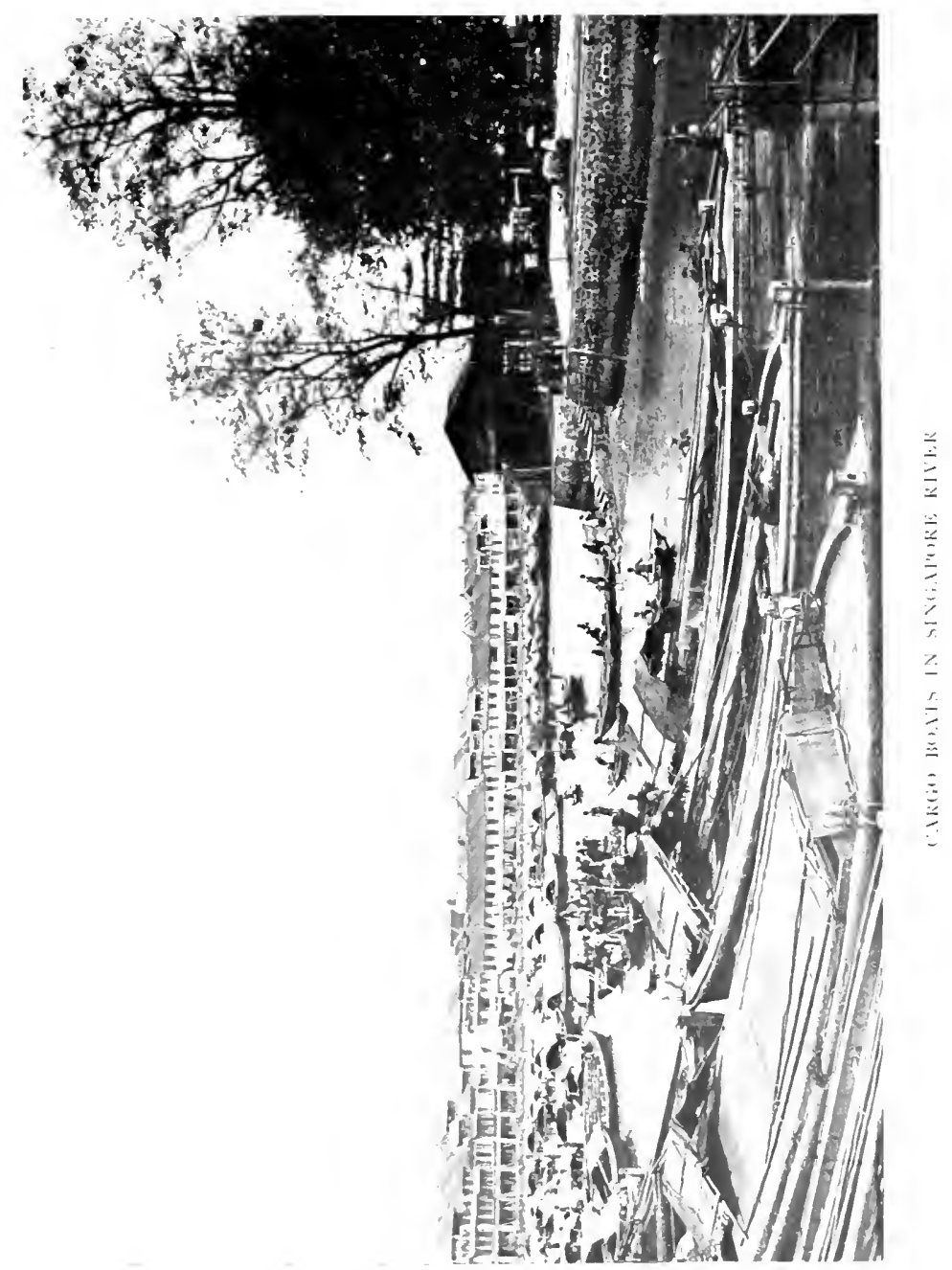



It is certain that the prosperity of the Straits Colony is due to three factors: (I) The geographical positions of Singapore and Pinang and the facilities afforded for the coaling, watering, and repair of ships ; $(2)$ the fact that all the ports of the colony are free; $(3)$ the development of the

though not stated, are estimated to exceed $£ 40,000$, but that estimate is not authoritative. The award works out, at the present 2 s. $4 \mathrm{~d}$. dollar, to $\$ 755$ per share of $\$ 100$; but when the Government elected to go to arbitration the dollar was worth less than $2 s$., and the award is, therefore, equal to $\$ 880$ per share. Before notice of expropriation had been given to the company the Government of the Federated Malay States purchased about 3000 shares at prices varying from $\$ 315$ to $\$ 350$, and the latter figure may be taken as the market price at that time, though the Under-Secretary stated in the House of Commons that, after notice had been given, the shares were for a short time quoted at $\$ 240$, and it is difficult to understand why the Government did not buy every share they could get at that price. The Government, with the fullest knowledge of all the facts, appear to have made an offer of $\$ 240$ a share to the Company, and state that this was met by a demand for $\$ 700$ a share. No effort was made to settle the matter by amicable arrangement, but the Colonial Office decided to go to arbitration, with the result stated. The shares were quoted in Singapore on 21 June at $\$ 4 \delta_{5}$ (sales), and the award was not known till $14 \mathrm{July}$. There is good reason to believe that there would have been no difficulty in coming to terms with the Company without arbitration, and that the colony-which has to pay both the award and the costs of arbitration-would have been saved about $£ \mathrm{I}, 750,000-\mathrm{a}$ large sum for a place with a total annual revenue of half that amount. Comment is needless; but as it will cost about $£ \mathrm{I}, 500,000$ to put the docks in thorough order and provide the extra wharfage required by the needs of the place, this note is added to qualify my statement that it was right for the Government to acquire the property and spend a sum which the company could not afford to put the undertaking on a thoroughly satisfactory footing. It would have been to the interest of the colony to have acquired the docks by guaranteeing 12 per cent interest on the nominal value of the issued shares, or by paying up to $\$ 400$ or even $\$ 500$ a share at a time when the sterling value of the dollar did not exceed $2 \mathrm{~s}$. To pay double that price, when the cost runs into millions, is a different thing, and how the Government is going to saddle the undertaking with the interest on the capital they must now borrow to pay the award and carry out the improvements (it will exceed $£ 5,000,000)$ and still make the business a financial success, without raising the dock charges, is a problem which can only be solved by the "experts" who deliberately sought arbitration in preference to an amicable arrangement, which, besides being far cheaper, would have saved much bitter feeling and all the heavy expenses. Moreover, the Government fixed the sterling value of the Straits dollar at 2 s. $4 \mathrm{~d}$., with this award hanging over their heads, when the dollar had for seven years been worth 2 s. or less, and for about six months had, for not very evident reasons, risen above that figure. 
Malay hinterland. To maintain the advantages hitherto enjoyed it is necessary to spare no trouble or expense to attract shipping by offering every convenience which modern trade requirements can reasonably expect. That the ports of the colony should continue to be free is obvious, and, so far as the colony can exercise any influence in the matter, the further development of the Malay Peninsula is of immense importance. In the early years of the Malay revival much of the success gained was due to the assistance rendered by coasting steamers owned in Singapore and Pinang, and a considerable fleet of small boats has been built and devoted to this service, to the mutual benefit of the owners and the States whose needs they served. The Malay railways are the property of the Malay Government, and, when the trunk line reaches Johore, there must be competition between it and the coasting steamers for the carriage of passengers and goods, but it will be a mistake if the railway is regarded as a commercial undertaking worked with the intention of making large profits as a first object. What might appear to be the gain of the railway as a dividend-earning investment, would probably result in damage to the Malay coast ports and all the surrounding country which has no railway service. It has been one of the features of the Malay Administration to encourage the growth of small towns all over the States, at district centres on the coast as well as inland. If the coasting steamers found it no longer profitable to call at these places, the welfare of the planting and fishing industries on the coast could hardly fail to suffer. There are on the west coast many rivers navigable to small steamers, and all of them fall into the sheltered waters of the Straits of Malacca. On the east coast it is different; the mouth of every river is barred by sandbanks, and during the north-east monsoon there are heavy breakers right along the coast. At one place only, Kuantan in Pahang, the conditions are rather more favour- 
able, and there it would be possible to provide protection at a moderate cost. The advantage of having such a port is manifest, and as the Federated States have plenty of funds, and the project has been under consideration for some years, the necessary works will probably be undertaken shortly.

The interests of the colony and the Malay States are not identical on every subject; for instance, the colony's currency,- - the Straits dollar, the subsidiary silver and copper coinage, and the Government currency notesconstitutes the only legal tender in the Federation. It has recently been decided that the gold value of the Straits dollar shall be two shillings and fourpence. Until within the last few months, the exchange value of this coin has, for many years, been only two shillings or less. It is clear that a two-shilling dollar would be much more agreeable to the miner and planter of the Peninsula than a dollar with a sterling value so high as two shillings and fourpence. The colony, however, produces practically nothing for export to gold-using countries, but it is a considerable advantage to all property-owners, bankers, and others who have money invested in business in the colony, to find that the dollar, so long worth only two shillings, has appreciated by over 16 per cent. Still speaking generally, the interests of the colony and the Protectorate are so nearly at one that they must stand or fall together, and neither can afford to adopt a policy which would seriously damage the other. In one respect the Malay States have an advantage: they are not open to the direct attack of an enemy, because no very large vessel can safely get to the shore at any point on the Malay coast. No enemy would find the railway of much use to him, for it would be easy to make it impassable, either by defending a given point or by destroying a bridge, and any attacking troops or blue jackets who landed and penetrated to any considerable place in the 
interior would have a poor chance of returning. The Malay States fully recognize that their own position of comparative safety does not entirely safeguard their interests or cover their obligations, and they are therefore prepared to assist in the defence of Singapore should it ever be in danger of attack from an enemy of the Imperial Government.

It may seem strange that, in an account of the results of a policy which owes its initiative to a Secretary of State for the Colonies, so little reference has been made to the Colonial Office. The explanation is simple if the reader remembers that the instructions from Downing Street were that the functions of the Resident were to be confined to the giving of influential and responsible advice. Having laid down that policy the Colonial Office could not well interfere, and, beyond the fact that the Secretary of State kept in his own hands the appointment of the Residents, he was satisfied to hear from the Governor that unexpected success was attending the new experiment, and to read in the annual reports of the Residents the details of the gradual evolution of a scheme of administration the efficiency of which was proved by the results. If the advisers were exceeding their functions there was no reason to complain, so long as every one concerned appeared to be satisfied and the States found means to meet all their liabilities. The terms of Federation empowered a British officer, the Resident-General, to exercise a very large control over the protected States, and from that date (1896) the Colonial Office has, in some important matters, made its authority felt. Reference has already been made to the construction and control of railways, and the relations of the Crown Agents and consulting engineers to the Federated Malay States in regard to these matters. Speaking broadly, the Colonial Office confines its interference to questions dealing with the appointment, promotion, and salaries of European officers selected for service in the Malay States. The whole 


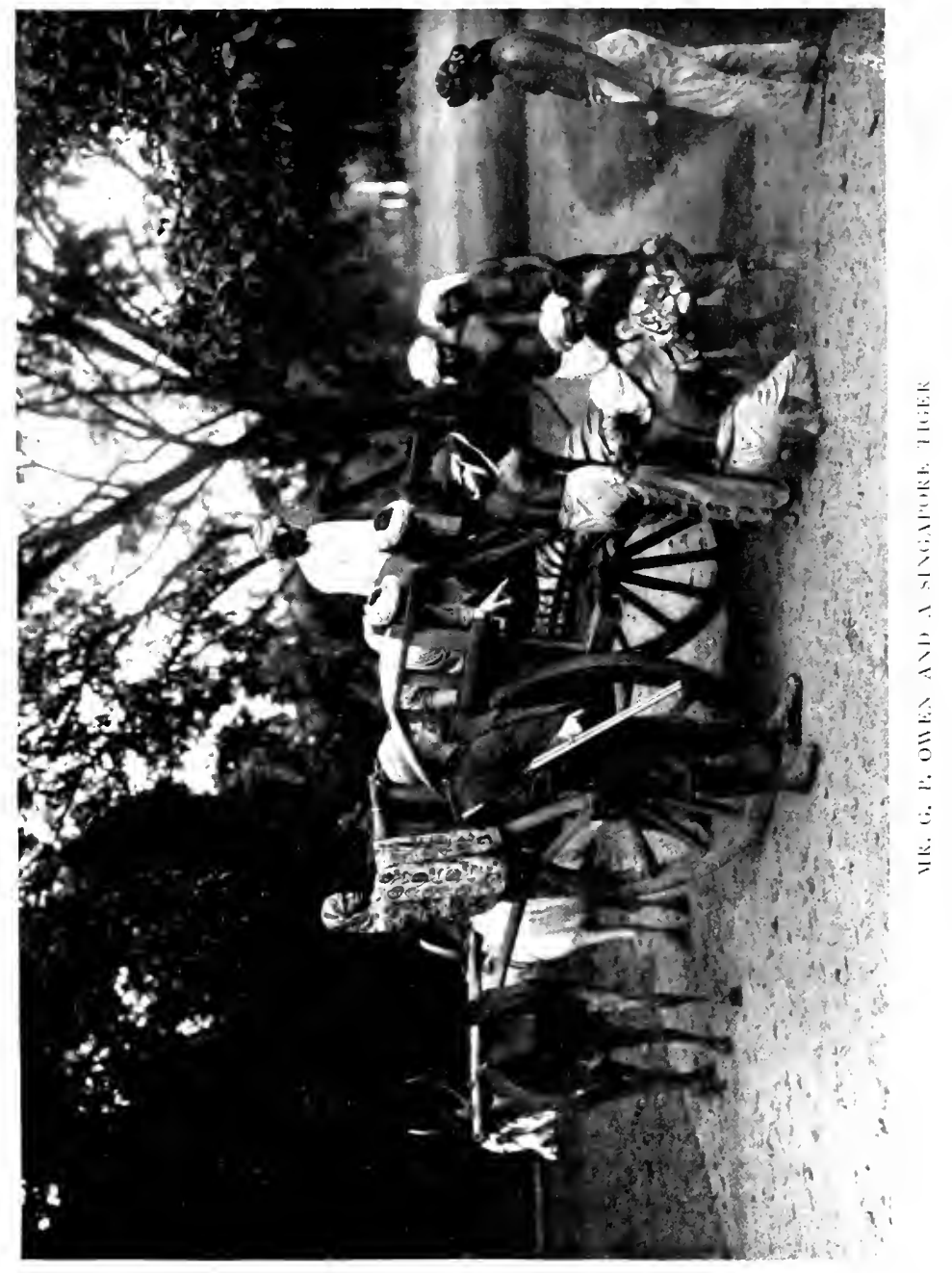



scheme for the reorganization of the various branches of the Government service and for the payment of salaries in sterling was submitted to, and received the approval of, the Secretary of State. There were two very excellent reasons why this should be so: first, because the salaries of all European officers in the Straits service were similarly revised at the same time, and were also placed on a sterling basis; and, secondly, because it was then laid down that the officers in both services should be interchangeable, and that all of them should thus be granted the benefits of a wider field of employment and promotion. All the members of the covenanted services of the colony and Federated States are now selected after competitive examination by the Civil Service Commissioners. One examination is held for admission to the Home, the Indian, the Malay, and the Eastern Colonial Services (the last include Ceylon, the Straits Settlements, and Hong Kong), the papers for all candidates are the same, and successful competitors are posted to the various services in the order in which they pass the examination. The test is a severe one, and, if it is admitted that competitive examination is the best means of recruiting the Government services in these places, no exception can possibly be taken to the present system; but, having regard to the special circumstances of the Malay States, (which are not British possessions) it is probable that the most satisfactory method of filling vacancies in that service would be by nomination, followed by competitive examination, at fixed annual periods, amongst those nominated. The conditions as to age, etc., and the scheme of examination should remain as at present, but if all competitors had first to receive a nomination from a responsible authority, say the Secretary of State or the High Commissioner, there would be less chance of the appointment of any one who was really unfitted to hold a Government Office in the Malay States. 
What are known as the Colonial Office Regulations are supposed to have force in the Malay States, though it might be hard to find any sufficient authority for their observance. These regulations were framed many years ago, and though occasionally revised in some details, they are expected to apply equally well to places so different as Ceylon, Malta, British Honduras, and Sierra Leone. It is not necessary to criticize them further than to say that the Governor of a colony with a population of several millions and a revenue of millions sterling cannot grant a week's leave to a clerk without consulting his Executive Council, and cannot sanction the unforeseen expenditure of sixty pounds without obtaining the sanction of the unofficial members of the Legislative Council. The Federated Malay States have no constitution of the Crown Colony type, and, therefore, they have been able to spend their funds without these restrictions, to the great benefit of the country. The Crown Colonies are, of course, on a different footing, but it is probable that amended regulations could be framed for the important colonies which, while providing all necessary safeguards, would give greater liberty of action and better results. It is perhaps curious that Great Britain, with so many colonies in different parts of the world, has never adopted any system, such as that which obtains in the French colonies, by which the best methods of administration are carried from one colony to the other by one or two inspecting officers, who periodically visit the colonies and advise the Governors and heads of departments as to the introduction of reforms. Such men, of high standing, liberal views, and large experience, would become most valuable advisers to the Secretary of State and his assistants, and would supply the necessary link between the most distant dependencies and the controlling authority in the Mother Country.

There is one subject which touches the distant worker 
more nearly than is perhaps realized; it is the great value which these exiled servants of the King attach to the dispensation of honours. After all, it is not unnatural that a man should highly prize this public recognition of good service, and when he spends all the best years of his life thousands of miles from his country, his home, and his friends, often in an unhealthy climate, always deprived of many things which make for happiness, he is apt to feel some bitterness when he sees that others, with less effort and less reason, have gained some coveted distinction denied to him. There is no need to discuss the feeling or how far it is worthy; it is there, and not less strong if seldom expressed. To men who unite character with the acknowledged performance of great services, the best reward is the consciousness that they have made life better for others, have accomplished something that will last, that will bear good fruit long after they have passed. To these the failure to obtain this kind of recognition means less; but even they cannot altogether avoid some heart-sickness when others, with less claim, obtain the public recognition which never comes to them. If there were no dispensation of honours for services such as these, there would be no feeling of bitterness. If such distinction were only conferred for great and special services, no reasonable man could complain. The soreness and the sense of neglect, possibly even some jealousy, are caused by what looks like the uneven distribution of loaves and fishes. It is no doubt difficult to decide between the merits of those whose names are, for various reasons, put forward for recognition, and others who have lived their lives out of sight and hearing, on the frontiers of the Empire, striving earnestly to better the lot of an alien and unattractive race. So many of England's sons, no better and no worse than others, but still men whose whole hearts are in their work, who give everything they have to drive the littlest of the wheels of State, proud of 
their opportunity and determined to make the most of it, so many of these die exiled, unhonoured and unknown, and lie buried thousands of miles from kith and kin, without ever tasting most of the pleasures which others will not sacrifice, that one is fain to wonder whether the Colonial Office ear is sometimes deafened to distant murmurs by the importunate cries of those at the door.

Compared with large questions of public policy and the common weal, a plea for the recognition of individual merit sounds trifling. But is it so? We know that the best ships and the best guns are useless without the right men to handle them, and that is the case in the equally exacting, if far less exciting life of the exiled civilian. The country does not want eye service and lip servicejust enough to satisfy outward seeming; it asks for all his time and zeal and ability, and to get it the servant should feel that good work will be rewarded.

The facts already recorded lead unmistakably to the conclusion that the future of the Straits colony depends upon the observance of principles which have brought it to its present position of prosperity, and that is even more true in the case of the Malay States. Free trade and facilities for shipping are necessary to the expansion of the colony, which is essentially a place of business, a market, a port of call, the Clapham Junction of the Eastern seas. The future prosperity of the Malay States depends upon a continuance of that special sympathy and consideration for Malays which those who were entrusted with their fortunes in the past insisted upon as a duty and came to regard as a pleasure. There must be even justice for all, a liberal land policy, the encouragement of immigration, especially from Southern India and China, the expenditure of public funds on great and carefully considered works of development and public utility. Lastly, the high standard of the public service must be maintained, the right class of man must be attracted to give his life and 
energies to an administrative task of profound interest, and the Government must continue to insist that its servants learn the languages of those whose affairs are placed in their keeping, must consult their interests first, and always remember that "they are there for the benefit of the people of the country."

Only a few months ago there died in Pêrak a man who cannot be replaced. He was the Raja Muda, the cousin and natural successor of the Sultan. He cannot be replaced because he was in the prime of life, of fine character, experienced in all the affairs of State, able, energetic, just and high-principled, honoured and loved by his countrymen, and deeply respected by all Europeans who were fortunate enough to know him. It will be necessary to go to another generation to find a Raja Muda; the choice is not large, and men of the type of the late Raja Musa $^{1}$ are rare. His loss will be keenly felt by the Sultan of Pêrak, who himself stands for all that is best in the Malay ruling class. Sultan Idris has all the qualities possessed by his cousin with a higher intelligence, a wider experience, and while Raja Musa was shy and retiring, the Sultan has great charm of manner and is a fluent speaker. The Sultan is a very earnest Muhammadan, without a trace of bigotry, and he is recognized as a high authority on questions of Muhammadan law and religion. In all the Malay States there is no one who, by his authority, influence, and direct assistance has done so much to promote the success of the new system of administration as Sultan Idris, on whom the Prince of Wales conferred the Grand Cross of St. Michael and St. George, when His Royal Highness visited Singapore on the memorable colonial tour of Igor.

Amongst the Pêrak chiefs, men with great influence and a wide authority, there are not a few who have

1 Raja Muda is the title of the heir apparent; Musa was the name of the late Raja Muda of Pêrak. 
proved their capacity to hold high office. One must be mentioned, the Dato Sri Adika Raja, I.S.O., the ablest Malay in the four States, and who in his sphere has been to British officers as loyal and firm a friend, as valuable an adviser and assistant as the Sultan of Pêrak, his master. There are earnest and capable Rajas, loyal and energetic chiefs, in all the States. It would be wrong to try and name them, for an accidental omission could not be remedied. It is enough to know that they are there, and the three I have mentioned suffice to prove that the Malay must not be regarded as a negligible quantity in his own country. The Sultan of Pêrak, the late Raja Musa, and the Dato Sri Adika Raja were in no sense the product of English education. None of the three ever had any experience of an English school, but all of them learned much by a keen observation, by a desire to serve their country, and by a close association with British officers in all that has been done to bring the Malay States to their present position. A Far Eastern race which can produce men like these, who, under such circumstances, develop principles as high as those which guide the best Europeans and strive to live up to them, is not to be despised or dismissed as useless.

We have learned by long experience, by our own blunders, and by such success as has attended our venture in Malaya, that when you take the Malay-Sultan, Raja, chief, or simple village head-man-into your confidence, when you consult him on all questions affecting his country, you can carry him with you, secure his keen interest and co-operation, and he will travel quite as fast as is expedient along the path of progress. If, however, he is neglected and ignored he will resent treatment to which he is not accustomed and which he is conscious is undeserved. If such a mistake were ever made (and the Malay is not a person who is always asserting himself, airing grievances, and clamouring for rights) it would be 
found that the administration had gone too fast, had left the Malay behind, left him discontented, perhaps offended, and that would mean trouble and many years of effort to set matters right again.

All is well now, and a reasonable consideration for the people of the country will keep it well. The danger is that the legitimate aspirations of a people who are too reserved to complain aloud may be overlooked. If this record, with its lessons of the past and the experience of a long and close intimacy with Malays, serve to warn others to avoid that danger, the purpose of the book is gained.

Time means progress and expansion for all that part of Malaya which comes under British influence. It will continue to make rough places smooth and to attract strangers of all colours and nationalities to a country big with possibilities of great development. But time will not change the Malay character, or alter the fact that the Malays are "the people of the country" whose confidence we have gained by making their interests our first consideration. 



\section{INDEX}

Abbott, R.N., Lieutenant, 201, 205, 206

Abbott, Lieutenant, escapes assas. sination, 206

Abdullah, son of Abdulkadir, 57-61, $63-5,68,75-7,79-81,168$

Abdullah, Raja, 122, 123, 176, 177, 194-6, 199-201, 210, 212

Abdullah, Sultan, summoned his chiefs, 201

Account of Siam, 97

Achin, 70, 108, 109, 326

Address presented to Sir Stamford Raffles, 73

Agricultural development, 248, 259$66,287,296-8,301,302$

Albuquerque, $6,14-18,22,57$

Ali, Sultan, 122

Alor Star, 310,311

Âmok, 143

An Anecdotal History of Singapore, 68

Anarchy in the Malay States, I 14-32

Anderson, John, pamphlet about Pinang, 53

Annual Budget and Report of British Residents, 248, 249

Anson, Colonel Sir A. E. H., 245

Appointment, etc., of Government officials, 338, 339

Appreciation of Mr. Chamberlain, 279

Arak, 253

Art work of Malay, 138

Ashanti Expedition, I08-10

Assassination of Mr. J. W. Birch, 203-I 5

Bachitram Shah, Raja (Sang Sěperba), 12

Bâdang, a Singapûra Samson, 8o
Bandar Bhâru, 201-8

Bandar Langat, "City of Festivals," 183-6, 191

Bandar Maharâni, 307

Bangkok Treaty, 316, 321

Bâtang Pâdang, I I 8

Beauty of the Straits of Malacca, 2-I I

Begbie, Lieutenant, 80

Bencoolen, 33, 34, 65, I I I

Běndahâra's betrayal of Singapûra, 14

Běndahâra's fate, 14

Běndahâra of Păhang, 131, 176

Bentan, 66

Bentinck, Lord William, 8I

Bënua, 26

Bernam, 116, I18, I26

Bernam river, I 16

Birch, Mr. E. W., 286

Birch, Mr. James W., 192, 194-2 I 5

Blanja, 202, 203, 207, 208

Blundell, Mr. E. A., 85, 88-93, 95, 98

Bonham, Mr., Governor of Singapore, 79

Boys, Malay, I35, 151

Braddell, Mr., I 12 , I 76

Britain's debt to Sir Stamford Raffles, 72

British flag hoisted at Pinang, 35

British Intervention in the Western Malay States, 1 73-272, 305

British prestige in Malaya, 329

British Residents in the Malay States, 177-305, 309, 330-45

Brown, Major, of the East India Company, 56

Buckingham and Chandos, Duke of, II 4

Buckley, Mr. C. B., 68

Bukit Putus, 2 IO

Bull-fights in Kelantan, $3^{14}$ 
Bungalows, 267

Butler, Mr. Arthur, 303

Butterworth, Colonel, 85-7, 93-5

Buying the heads of the enemy, I3I

Cameron, Mr. W., 267

Canning, Lord, 105-8

Cape Rachado, 6

Carnarvon, Lord, 177, 184, 216, 217

Caulfeild, I.s.o., Mr. F. St. George, 260,278

Cavenagh, Colonel Orfeur, 320-2

Chamberlain, Mr., 256, 279

Channer, v.c., Captain, 210

Character of Sir Harry Ord, I04, I08

Chartered Bank of India, Australia, and China, 252

Children, Malay, 135, 136, 150-2, 257

Chinese, 115-18, 129-31, 176, 177, 194, I 95, 227-35, 239, 247, 249-57, 260, 26I, 275-7, 292, 293, 30I, $302,307,310$

Chinese secret societies, 227, 250-6

Chinese sign Bond, I77

Cholera, 243

Church, Mr. T., 94-9

Cinchona, 262

"City of Festivals" (Bandar Langat), I83-6, I9 I

Clarke, Sir Andrew, 133, 173-94, I98, 213

Class distinction in Malaya, I4I

Clifford, Mr. Hugh, 167, 270, 271

Climate of Malacca, 25

Clubs, 266, 267

Cock-fighting, I 36, 139, 314

Coffee, 262, 263

Colborne, Major-General the Honourable F., 208, 209

Colman, Mr., 8o

Colonial Office, $33^{8-41}$

Commission under the Pangkor Treaty, $177-82$

Commissioner of Police, 276

Complicity of Sultan Abdullah in the murder of Mr. Birch, 2 Io

Conference of Malay Rulers (1897), 288-9 I

Conference of Malay Rulers (1903), 291

Cornwallis, Lord, 34

Courts of Justice, 228
Cowardice of the East India Company, 37

Crawford, Mr. John, I 5, 89, 96, 97 , I I 2, I 58-65, 317

Crawford, Mr., visit to Malacca (I821), 15

Crown Agents for the Colonies, 280-2, $33^{8}$

Currency, 267, 268, 336, 337

Curzon, Lord, 304

Customs of the Malay, I33-72

Daily journals of the British Residents, 248, 249

Dato' Akek, 188

Dato' Bandar and Dato' Klana, I 86-92

Dato' Lakzsamâna, 2 Io

Dato' Sậ̂or, 20I, 205, 208, 2II, 212

Dato' Shabandar, 2 IO, 2 I 2

Dato' Sri Adîka, Raja, 344

Davidson, Mr. J. G., 192, 210, 211 , $213,220,225$

Death rate high, 24I

Debt-slavery, 14I-3, 195, 196, 227

Denison, Mr. Noel, 303

Despatch of Lord Carnarvon (I June, 1876), 2 I6, 217

Destruction of forts, etc., under the Pangkor Treaty, 177, 179-82

Development of the Malay States, 2 I6-305, 309, 330-45

Development of the Malay States, its effect on the Straits Settle. ments, 330-6

Dictionaries, Malay, 167

Dindings, I, I14, I1 7,126 , I 76

Director of Agriculture, 287

Distribution of proclamation of appointment of Queen's Commissioners, 20I-7

District Magistrates, 242, 302

Divorce, 154

Docks at Singapore, 8, 10, 333, 334

Dollar, the Straits, 336,337

Douglas, Captain Blomfield, 2 Io

Dress of the Malay, I 34

Dunlop, Colonel, i 76, 177, 21 I

Dutch, 6, 18, 19, 33, 56, 57, 61, 325

Dutch Stadt House at Malacca, 6, $57,6 \mathrm{I}$ 
East India Company, I, I9, 33-52, $56,62-77,84$-IOI, I I I, 320, 327, 329

Education, I 5 I, I 52, 250, 257-9

Electric lighting, 26I

Esplanade at Singapore, 75

Fame, destroyed by fire, 72

Farquhar, Colonel, 57, 66-71, 75, 81,325

Federation, 272-305

Festivals, I 48 , I 53

Fiscal reform, 222, 278

Fishing-fleet of Kelantan, 315

Folding Plains, I 50

"Forbidden Hill," 78

Fort Canning, 78

Fortifications of Malacca destroyed, 57

France and Siam, 323-5, 327

Gambir shrub, I12, 307, 308

Gambling, $83,255^{-7}, 307$

Gĕměncheh, I 3 I

Georges de Santa Lucia, Bishop of Malacca and the Forest Bĕnua, 26

Girls, Malay, I 50-2, 257

Godinho de Eredia, Manuel, MS., I9, 20, 26

Go Kuans, i 18

Gold in Păhang, 270

Government Geologist, 287

Growth of Singapore, 8 I

Gunong Jerai, 4

Gunong Lêdang, 6, 26

Gunong Pâsir, I3I

Harbour of Singapore, 8, 10, 333, 334

Hare, Mr. G. T., Secretary for Chinese Affairs, 275, 276

Hastings, Marquis of, 70,7 I

Hastings, Warren, 34

Hicks.Beach, Sir Michael, 2 I 8

High Commissioner for the Federated Malay States, 273, 288

"Hikaiat Abdullah," 57-6r, 63-5, $68,75-7,79-8 \mathrm{I}, \mathrm{I} 68$

Hill bungalows, 267

Honours, unequal distribution of, 340-2

Hospitality, Malay, I 49

Hospitals, 24 I, 242, 246

Houses, Malay, I 5 I
Humboldt, Baron William, I 58

Husein, Raja, 2 I I

Idris, Raja, Sultan of Pêrak, I76, 200, 343

Illness, its treatment in Malaya, 155

Indian Forest Department, 286

Indian Government, a friend to the Malay States, 287

Industries, $138,139,151$, I 52

Innes, R. E., Captain, 207, 208

Institute for medical research, 287

Instructions to Sir Andrew Clarke, I 74, 175

Iskandar, Raja, of Singapûra, I 4

Ismail, Raja, 122, $123,176,196,202$, $204,207-9,212$

Jackson, Mr. Lawrence, 276

Jafar, Sultan, 122

Jâlor, 3 I 3

Janssen, M. Léon, I9

Java, $57,62,63,65$

Jělěbu, I3 I, 220

Jěmpôl, I 3 I

Jěring, 3 I 3

Jervois, Sir William, 198-216, 220, 242,245

Jervois, Sir William, interviews the Malay chiefs, I 99

Johôl, I3 I

Johore, 2, 65, 66, 70, 8ז, 84-I0I, I I 2, I I 3,2 I I, 270, $278,279,306-$ 9, 328

Johore Bhâru (Silat Tembrau), 306

Johore Railway, 279, 308

Johore revenue, 307 -9

Johore Sultans, 65, 66, 70, 84-101, 270, 306-9

Judicial Commissioner, 276

Junk Ceylon (Sâlang), 34, 35, 31 3

Justice in the Malay States, 276, 277

Kampong Gâjah, 20I, 208

Kapak China of Raja Mahmud, I9I

Kapayang, I 90

Karîmun Islands, 7

Kĕdah, 5, 34-52, I I6, I 29, I 5 I, 209, 260, 309-I I, 316, 327-9

Kĕdah debts, 3 IO, 3 I I

Kĕdah, Sultan of, $34-52,129,130$, 209, 260, 310, 3 I I

Kĕdah taken by the Siamese, 52 
Kelantan, 314-16, 320, 322, 329

Kelantan amusements, 314

Kelantan fishing-fleet, 315

Kelantan peculiar customs, 314

Kelantan women, 314

Keppel Harbour, IOI

Kershaw, Mr. T., 275, 276

Kesang-Muar, 94, 95, 99

Kimberley, Lord, 174, 175, 178, 184

Kinta, I 8

Klang, I 27-30, 220

Kôta Bhâru, 3 I 4

Kôta Lâma, 201, 203, 209, 226

Kris, I46, I9I

Kuala Kangsar, 20I, 202, 208, 226, 228,288

Kuala Lumpor, 127-3I, 220, 26r, 266, 275, 29I

Kuantan, 336

Laksamâna, 202, 207, 212

Land Code, 284

Land laws, 236, 284, 285

Langat, 127

Language, $156-72$

Lankâwi Islands, 3 ro

Lârut, I18, I19, 123-6, I77, 194, I 95, 2I I , 2I, 279

Late dinner a Malay custom, 148

Laziness of the Malay, I 36, 137, 139, 305

Leith, Sir George, 46

Lela, Maharaja, 20I-3, 205, 206, 208, 2 I I, 2 I 2

Leprosy, 268, 269

Letters from Kèdah Sultans on the ceding of Pinang, $3^{8}, 47$

Leyden, Dr., 62

Ligeh, 313

Light, Francis, $34-52,54,55$

Light given out by centipedes and hares, 24

Lingga, ex-Sultan, Siamese send to Trĕnggânu, 320

Lion of Singapûra, I 3

Lister, the Honourable Martin, 272, 302

Literature, Malay, I67

Logan, Mr. J. R., I 3 note, II 2

Low, Sir Hugh, 213, 225, 227, 252, $253,262,263,290,298$

Low, Sir Hugh, death, 253

Loyalty, part of the Malay creed, 140
Lukut, I 14, I26, I27

McNair, Major, I 76

Macpherson, Sir John, 40, 56

Maharaja of Johore, II 4

Maharaja Lela, 20I-3, 205, 206, 208, 2 II, 2 I 2

Mahdi, Raja, 128, I 29

Mahmud, Raja, I29, I30, I90-2, $197,202-4,207$

Majapâhit, Raja of, 14

Malacca, I, 5-7, 12-33, 56-62, 66, $80-4,183,279,306$

Malacca, early history, 12-32

Malacca Railway, 279

Malacca restored to the Dutch, 57, 66

Malacca, Straits of, I-I I , 65, 69, 8I, I I I, I 16, I25, I26, I 3 I I 32, I83, 279, 306, 336

Malacca taken (1795), 56

Malacca trading boat pirated, 183 , 184

Malay boys, I 35, I36, I 51, 257

Malay dress, 134

Malay girls, I 50-2, 257

Malay laziness, I 36, I 37, I39, 305

Malay pirates, $78,8 \mathrm{I}$

Malay Rulers approve the federation scheme, 273, 274

Malay sensitiveness, I 43

Malay Sketches, 207 note

Malay States Guides, 277

Malay women, 147, 149, 150, I53-5

Mantri, I21-4, 176, 177, 194, 195, 210, 212, 219, 220

Marriage, Malay, I 52, 153

Marsden, Mr., I1 2, 158

Mat-making, I 5 I

Maxwell, Sir William, 2I I, 213

Metal work, I38, I39

Mining Code, 284

Minto, Lord, $57,59-63$

Miracles of St. Francis Xavier, 18

Mitchell, Sir Charles, 272

Mount Ophir, 6, 26

Mukim, 228

Murray, Captain P. J., 193, 303

Nakodah Orlong, 207, 208

Naning, 83

Negotiations at Kĕdah between the Sultan and the East India Conpany, 34-52 
Nĕgri Sambîlan, I, 114, 127, I31, 132, 194, 208, 209, 220, 221, 272, $273,278,279,288$

Negus, William, 36

Newcome, Captain, of the Orpheus, 56

Non-federated Malay States, 306-29

Nongchik, 313

Oil, mineral, in Malacca, 26

Ophir, Mount, 6, 26

Opium, 82, I 36, 253-5, 307

Ord, Sir Harry St. George, 104-33, I73, 198

Origin of the Malay race, 144

Păhang, 2, I 5 I, 270, 273, 329, 336

Pandak Indut, 205, 206, 2 I I

Parliamentary paper written by Sir Frank Swettenham at Pêrak, 293-8

\section{Paroe, 2 ro}

Pangkor Treaty, 176, 177, 195, 199

Pâsir Sâlak, 20I-8, 2 I I

Pawang (tin-finder), 229

Pawnshops, 253, 307

Pĕng-hülu, 228

Pěngkâlen Pigu, 209

Pepper, dollars and ants in Bencoolen, 33,34

Pepper vine, 33, 34, 112, 261, 307, 308

Pêrak, II 5, II 2, II4-I20, I25, I5I, 175, 177, 192, 194-215, 220, 221, $225-8,252,253,260-3,266,272$, $273,277,278,285,286,288,292-$ $8,313,314,342-4$

Pêrak constitution, 120-4

Pêrak museum, 266

Pêrak river, I I6-18, I76, 226, 313

Pêrak, Sultans of, I1 $12,120-3,176$, 177, 196, 199-201, $210-14,228$, 288, 291, 343, 344

Pêrak, Sultan's remarkable speech (1903), 291

Perilous journey after the murder of Mr. Birch, 203-5

Perlis, 310

Petâni, 313, 316, 328

Physical characteristics of the Malay, I 34, I 52

Pickering, Mr. W. A., I76, I77, 187-90

Pickering, Mr., extract from his journal, $187-9$
Pickering, Mr., mission to Pinang, I 76

Picnics, Malay, I 50

Picturesque Malacca, 6, 7

Pinang, $1-5,10,19,33-61,66,72$, 80, 81, 84, I I I, I I 5, 126, I 76, I 77, $280,288,328,333,335,336$

Pinang, early history, 33-6I

Pinang jealous of Singapore, 72

Piracy, "boy's play," 183

Pirates, 78, 81, 115, 125, 126, 183, 184

Plot to assassinate Mr. Birch, 200

Plunket, the Honourable H., 207, 208

Police, 22 I, 225, 256, 277

Polygamy, 1 53-5

Port Dickson, 279

Port Weld, 279

Portuguese in Malacca, 18

Pottery, Malay, 139

Prince of Wales, 343

Principal wife, 154,155

Prisons, 246

Proclamation of the appointment of Queen's Commissioners, 20I-7

Prosperity of the Malay States due to British Intervention, 302

Prosperity of Pêrak and Sělangor, 273

Prosperity of the Straits Settlements, 330-6

Proverbs, Malay. 169-7 I

Province Wellesley, I, 4, 5, 10, 46, I $16,118,126,259,278,279,306$, 333

Province Wellesley Railway, 279

Public Works Department, 278

Punitive Expedition, 208-10

Quays of Pinang, 3

Queen's Commissioners to replace Residents, 200

Queen-Empress, 288

Rachado Cape, 6

Raffles, Sir Stamford, 54, 57, 58, $61-84$, III, 112, 158, 317-20, 325-7

Raffles, Sir Stamford, instructions to Mr. John Crawford, 317-20

Raffles, Sir Stamford, instructions to Major Farquhar, 325

Railways, 239-4I, 250, 26I, 278-84, $296,308,328,333,33^{8}$ 
Raja Abdullah, Sultan of Pêrak, r22, I23, I 76, I77, 194-6, I99-20 I, 2IO, 212

Raja Bachitram Shah (Sang Sěperba), I2

Raja Běndahâra, I76

Raja Husein, 2 I I

Raja Idris, Sultan of Pêrak, I76, 200, 343

Raja Iskandar of Singapûra, I4

Raja Ismail, I 22, 123, I 76, 196, 202, 204, 207-9, 2 I 2

Raja Mahdi, I29, I30

Raja Mahmud, I29, I30, 190-2, 197, 202-4, 207

Raja of Majapâhit's attack on Singapûra, I4

Raja Musa, 343, 344

Raja Yusuf, I 22, 123, 176, 195, 197, 200, 202, 2II, 212, 214, 226

Ram-fights in Kelantan, 314

Regalia of Pêrak, 197, 209

Religions of the Malay, 144

Rěmân, 313

Rĕmbau, I3I, I32, 220

Rendong, $3 \mathrm{I} 3$

Report of the Pangkor Commission by Sir Frank Swettenham, 17982

Rescue of Chinese women and children, I77, I79-82

Resident-General, 273-75, 278, 284, $285,288-91,338$

Resident-General's Report of the Conference of Malay Rulers, 28991

Revenue and Expenditure of the Malay States, 222-27, 237, 248, 299-301

Revenue and Expenditure of the Straits, 82, 105, 106, 331, 332

Revenue of Johore, 307-9

Rhio, 69, 70

Rice, 259-6r, 302, 310

Ripon, Marquis of, 259

Rivers as highways, I19

Roads in the Malay States, 236-8, 240, 24I, 26I, 296, 310

Robinson, Sir Hercules, 103

Robinson, Sir W. C. F., 245

Rodger, Sir John P., 270, 272

Ross, Brigadier-General John, 208, 209

Royal colours of Malay, I35
Rozells, Martina, 36

Rubber, 262-6

Sai, 3 I3

St. Francis Xavier, 18

Salâma, I I 8

Sâlang (Junk Ceylon), 34, 35, 3I 3

Salaries of Government officials, 303 , $33^{8}$

Sang Nila Utâma, I 3 and note, I4

Sang Ranjûna Tapa betrays Singapûra, 14

Sang Ranjûna turned to stone, I4

Sang Sěperba (Raja Bachitram Shah), I 2

Sāyong, 226

Scheme of federation drawn by Sir Frank Swettenham, 272

Schools, I 52, 250, 257-9

Seal of Sultan Ali displeased, 100

Secret societies, Chinese, 227

Secretary to the High Commissioner, 275

Secretary for Malay affairs, 210, 247, 251

Sejâra Malayu, 12

Sĕlangor, I, I 12-16, I18, I 26-31, I5I, $183-6,192,197,208,210$, $214,216,220,261,273,275,278$, $29 \mathrm{I}$

Sĕlangor attacked by the Siamese, 53 Sělangor, Sultan of, 128-30, 183-6, 288

Senggôra, 310, 313

Seramban, 278,279

Sětul, 3 Io

Seychelles, 2 I 2

Seyyid Mashhur, I 29

Shadwell, Sir Charles, I 83

Siam and Kèdah, 40-5, 50-3

Siamese, 40-5, 50-3, 310, 313, 314, 316-28

Si Kuan, I 18, I23-5

Singapore, I, 7, 8, 10, 13, 14, 19, 31, $54,56,62-77,78-101$, II 1 , I12, 177 , 191, 192, 210-12, 326, 328, 333-6.

Singapore, early history, 62-77, 80

Singapore, the Clapham Junction of the Eastern seas, 342

Singapore treaty between the Sultan of Johore and the East India Company, 65 
Singapûra attacked by the Raja of Majapâhit, 14

Sireh, 149

Skinner, Mr. A. M., 176

Skulls floating in Singapore harbour,

Slavery, 14I-3, 195, 196, 227

Smallpox, 155

Smith, Sir Cecil C., 245, 250, 259, 270,272

Snake tree, 23

Speech of the Sultan of Pêrak (1903), 291

Speedy, Captain, T. C. S., I24, 177, 192, 213, 219

Spooner, Mr. C. E., c.M.G., 278

Sport in Malaya, 266, 267

Stadt House at Malacca, 6, 57, 6I

Stanley, the Honourable E. J., translation of the Duarte Barbosa MS., 17

State Council at Pêrak, 226, 227

Stone in the Singapore River, 15, 7981

Stones in the heads of snakes, 23

Straits, The (1825 to I867), 78-103

Straits, The (1867 to 1873 ), 104-I 32

Straits, The (I874), 173-93

Straits, The, severance from Indian control, 102

Straits of Malacca, 1-11, 24, 65, $69,81,111,116,125,126,131$, 132

Sucisa metal work, 138

Sugar, 260, 26I

Sultan Abdulah, 122, 123, 176, 177, 194-6, 199-201, 210, 212

Sultan Ali, I 22

Sultan Idris, 176, 200, 343

Sultan Jafar, 122

Sultan of Kĕdah, $34-52,129,130$, 26́o, 310, 3 I I

Sultan of Pêrak, I12, 120-3, 176, 177, 196, 199-201, 210-14, 228, $288,291,343,344$

Sultan of Sělangor, I 28-30, 183-6, 288

Sultan ofSělangor, Sir Frank Swetten. ham, British Adviser, I84-6

Sumatra, 22-2, 65, 66, 108, II I

Sumatra, the derivation of the word doubtful, 20-2

Sungei Raia, 126

Sungei Ujong, 131, 132, 186-92, 197, 198, 2 10, 220, 279
Swettenham, Sir Frank, mission to Lârut, I 76

Swettenham, Sir Frank, ResidentGeneral, 275

Swettenham, Sir Frank, Secretary for Malay affairs, 2 Io

Syers, Mr. H. C., Commissioner of Police, 276, 303

\section{Taipeng, 277}

Tămâsak, I 3

Tanjong Pagar Dock Company, 334 and note

Tatham, Captain, 192

Taxation, 136

Tea, 262

Telegram from the Malay Rulers to the Queen-Empress, 288

Těměnggong of Johore, $65,66,69$, $70,78,8 \mathrm{I}-\mathrm{IOI}, \mathrm{II} 2, \mathrm{I} 14, \mathrm{I} 76$

Terâchi, 210

"The late Sultan, God-pardon-him," Yusuf, 226

The Real Malay, 143 note, 192 note

Thompson, the Reverend Mr., 79

Tigers of Malacca, 26, 29, 30

Tin Mines, I15, 118, 123, 129, I3I, I94, 219, 228-39, 248, 254, $255,259,261,270,295-7,307$, 310

Tin smelting at Singapore, 333

Toh Muda, I 89

Tongkah, $3^{\mathbf{I}} \mathbf{3}$

Trade increase of the Straits Settlements, 33I, 332

Trade with the Malay States, 174, 175

Treacher, Sir William, 272

Treatment of Tunku Ali by the East Indian Company, 85-10I

Treaty of Bangkok, 316, 321

Treaty between the East India Com. pany and the Sultan of Johore, 65 , 67,69

Treaty of Federation, 273

Treaty of Pangkor, 176, 177, 195, 199

Treaty of Vienna, 19

Trĕnggânu, 2, I 52, 316-23, 326, 328, 329

Trial of the murderers of Mr. Birch, 2 I I

Trigonometrical survey of the Malay States, 285,286 
Tunku Ali, Sultan, 85-101

Tunku Antar, Yam Tuan of Sri Měnanti, 220

Tunku Muhammad, c. M.G., Yang di Pertuan of Nĕgri Sambilan, 221

Ulu Muar, I3I

Umbrellas instead of weapons, 135

Unsettled condition of the Western Malay States, I73-93

Vaccination, 155

Valentyn, François, account of Malacca, 27-9

Van Naarsen and the tiger, 29

Vaughan, Mr. J. D., 2 I I

Verse, Malay, 168

Victoria Cross awarded to Captain Channer, 210

Victoria, Queen-Empress, 288

Village head-men, 304

Vincent, Mr. Claude, 260

Walker, C.M.G., Colonel, 277

Water, 235, 236, 260, 26r

Water-course under Government control, 235, 236

Weapons supplanted by umbrellas, 135

Weaving, 151,152

Weddings, Malay, 153

Weld, Sir Frederick, 245, 249, 289

"What you can't mend don't destroy," 80

Wha-wei, 257

White man's dress indelicate, 147

White men, Malay popularimpression, 145

Wilkinson, Mr. R. J., 167

"Wise women," 155

Women, Malay, $147,149,150,153-5$

Wood-carving, 138,139

Wray, 266

Yam Tuan of Sri Menanti, 220

Yang di Pertuan of Něgri Sambîlan, 221

Yusuf, Raja, 122, 123, I 76, 195, 197, 200, 202, $211-14,226$

Yusuf recognized as Sultan of Pêrak, $2 \mathrm{I} 3$ 


\section{BY THE SAME AUTHOR}

\section{MALAY SKETCHES}

\section{With Title-page and Cover designed by Patten W ILson}

\section{Crown 8 ro. 6s. Third Edition}

Pall Mall Gazette._- Sir Frank Swettenham's style is simple and direct and vigorous. Particularly good is his eye for colour, and he has a fine sense of the brilliant melancholy of the East. To few falls the good fortune of introducing us to a new people, and seldom have we the advantage of so admirable a guide."

Spectator. - "This is one of those books which exercise such a fascination upon the mind of the stay-at-home traveller. Stay-at-home though he may be. he has no difficulty in distinguishing the work of a genuine authority from the hasty and inexact impression of the idle globe-trotter. 'Malay Sketches' will be speedily recognized by him as belonging to the more reliable kind of his favourite literature."

Daily Chronicle._- Nothing approaching Sir Frank Swettenham's intimate knowledge and illuminative analysis has yet seen the light about that fascinating country which he so well describes."

\section{UNADDRESSED LETTERS}

\section{With Portrait of the Author. Crown 8vo. 6s. Fourth Edition}

Athenaum.- "Deep gratitude is due to Sir Frank for giving these letters to the world. . . . The happy description of Eastern life, the musings on great scenes, the stories and the utterances of social wisdom, are all delightful, and add body to a book remarkable for a rare delicacy and charm."

Pall Mall Gazette. - "His narrative style is admirable, and his episodes are al ways interesting. One could read for many hours of the clever mongoose and tigers and crocodiles. ... Sir Frank Swettenham has a pretty humour. .. .The style in which these "Unaddressed Letters' is written is excellent."

Daily Chronicle._" "Unaddresssed Letters' is the revelation of a personality at once sympathetic and distinguished, imaginative, sensitive, emotional."

Academy._-"We cordially welcome the book. It is a generous self-revelation of uncommon candour, in a form sufficiently unfamiliar to preserve the charm of novelty."

\section{THE REAL MALAY}

\section{Pen Pictures. Crown 8vo. 6s.}

Manchester Guardian.- "Altogether this book, written by a man who has made a close study of the Malay and who possesses in a high degree the power of vivid description and subtle analysis of character, will be full of charm to any one who has an eye for the bright lights and deep shadows of the tropic East."

Daily Telegraph._- A collection of masterly character sketches taken from the life, and illustrating a few of his most noteworthy personal experiences, acquired during a long sojourn in the Straits Settlements. All the character sketches, fifteen in number, are highly-finished works of art; pre-eminently so is a 'genre' picture of a malignant monkey, which proved fatal to every human being brought within the sphere of its baleful influence, and gave rise to long-protracted litigation." 


\section{BOOKS OF INTERNATIONAL INTEREST}

\section{GREAT JAPAN}

A Study in National Efficiency. By Alfred SteAd. With a Foreword by the Earl of Rosrbery. Demy 8vo, 10s. 6d. net. Second Edition

\section{BOMBAY DUCKS}

An account of some of the Every-day Birds and Beasts found in a Naturalist's El Dorado. By Douglas Dewar, F.z.s., 1.c.s. With numerous Illustrations reproduced from Photographs by CAPTAIN Fayrer, 1.M.s. Demy 8vo. I6s. net

\section{MOORISH REMAINS IN SPAIN}

Being a Brief Record of the Arabian Conquest and Occupation of the Peninsula, with a Particular Account of the Mohammedan Architecture and Decoration in the cities of Cordova, Seville, and Toledo. By A. F. Calvert. With 84 Coloured Plates, 200 Black and White Illustrations, and 200 Diagrams. Crown 4 to. 42s. net

\section{WITH THE PILGRIMS TO MECCA}

The Great Pilgrimage, A.H. I3I8; A.D. I902. By HADJI KMAN and Wilfrid Sparroy. With an Introduction by Professor VAmbery and many Illustrations. Demy 8 vo. 12s. 6d. net

\section{IMPERIAL, VIENNA}

An Account of its History, Traditions, and Arts. By A. S. Leverus. With upwards of I 50 full-page Illustrations by Erwin Puchinger. Demy 8 vo. I 8 s. net

\section{AFRICA FROM SOUTH TO NORTH}

THROUGH MAROTSELA N D

By Major A. ST. H. GibBons. With numerous Illustrations from Photographs, and Maps. Demy 8vo. In Two Volumes. 32s. net

\section{RIFLE AND ROMANCE IN}

\section{THE INDIAN JUNGLE}

Being the Record of Thirteen : ears of Indian Jungle Life. By Captain A. I. R. Glasfurd. With numerous Illustrations by the Author and reproductions from Photographs. Demy 8vo. 7s. 6d. net

HISTORY OF THE NORTHERN INTERIOR OF BRITISH COLUMBIA

By the Rrv. A. G. Morice, O.M.I. With 35 full-page Illustrations and a Map. Demy 8 vo. 16s, net

LONDON : JOHN LANE, THE BODLEY HEAD, VIGO STREET, W. NEW YORK: JOHN LANE COMPANY, 67 FIFTH AVENUE 



\section{UCSB LIBRARY \\ $X-35683$}

THE LIBRARY

UNIVERSITY OF CALIFORA'

conta Pu-bara 


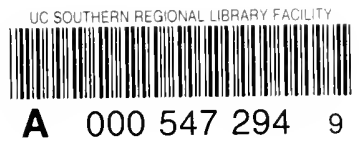




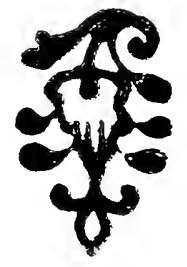

